\title{
Depicting skin : visual culture in nineteenth-century medicine
}

Citation for published version (APA):

te Hennepe, M. (2007). Depicting skin : visual culture in nineteenth-century medicine. [Doctoral Thesis, Maastricht University]. Maastricht University. https://doi.org/10.26481/dis.20070920mh

Document status and date:

Published: 01/01/2007

DOI:

10.26481/dis.20070920mh

Document Version:

Publisher's PDF, also known as Version of record

\section{Please check the document version of this publication:}

- A submitted manuscript is the version of the article upon submission and before peer-review. There can be important differences between the submitted version and the official published version of record.

People interested in the research are advised to contact the author for the final version of the publication, or visit the DOI to the publisher's website.

- The final author version and the galley proof are versions of the publication after peer review.

- The final published version features the final layout of the paper including the volume, issue and page numbers.

Link to publication

\footnotetext{
General rights rights.

- You may freely distribute the URL identifying the publication in the public portal. please follow below link for the End User Agreement:

www.umlib.nl/taverne-license

Take down policy

If you believe that this document breaches copyright please contact us at:

repository@maastrichtuniversity.nl

providing details and we will investigate your claim.
}

Copyright and moral rights for the publications made accessible in the public portal are retained by the authors and/or other copyright owners and it is a condition of accessing publications that users recognise and abide by the legal requirements associated with these

- Users may download and print one copy of any publication from the public portal for the purpose of private study or research.

- You may not further distribute the material or use it for any profit-making activity or commercial gain

If the publication is distributed under the terms of Article $25 \mathrm{fa}$ of the Dutch Copyright Act, indicated by the "Taverne" license above, 


\section{DEPICTING SKIN}


ISBN 978-90-6464-173-2

Printed by: Ponsen \& Looijen bv, Wageningen

(C)2007 Mieneke te Hennepe. All rights reserved. No part of this publication may be reproduced, stored in a retrieval system, or transmitted, in any form or by any means, electronic, mechanical, photocopying, recording, or otherwise, without the permission in writing from the proprietor. 


\section{DEPICTING SKIN}

\section{Visual culture in nineteenth-century medicine}

\section{PROEFSCHRIFT}

ter verkrijging van de graad van doctor aan de Universiteit Maastricht op gezag van de Rector Magnificus, Prof. mr. G.P.M.F. Mols volgens het besluit van het College van Decanen, in het openbaar te verdedigen

op donderdag 20 september 2007 om 12:00 uur

door

Mieneke Mathilde Geertruida te Hennepe 
Promotor:

Prof. dr. R. Zwijnenberg

Copromotor:

Dr. J. C. M. Wachelder

Beoordelingscomissie:

Prof. dr. K. Th. Bijsterveld (voorzitter)

Prof. dr. E. S. Houwaart (Vrije Universiteit Amsterdam)

Prof. dr. F. G. Huisman

Dr. B. Pasveer

Prof. dr. J. V. Pickstone (The University of Manchester, United Kingdom)

This research was supported by the Netherlands Organisation for Scientific Research (NWO).

The production of this book was supported by WTMC (The Netherlands Research School of Science, Technology and Modern Culture) and by the Faculty of Arts and Social Sciences of Maastricht University. 



\section{Contents}

\section{Acknowledgements}

1 Introduction

2 Surface of recognition

A visual vocabulary of diseased skin

Classification and visualisation

Skin diseases in early medical traditions $\quad 30$

Images that matter: more compartments of skin 35

The return of Alibert: clinical depiction 44

A visual language of skin diseases $\quad 48$

3 Thickening skin $\quad 55$

Microscopy and the science of skin

$\begin{array}{ll}\text { Open passage and present pores } & 57\end{array}$

Skin as object of investigation $\quad 61$

Visual articulation of the skin interior 66

Guiding the eye, working the pencil: on the function of pictures in microscopy 77

Thickening skin: from permeation to mediation 85

\section{The incalculable blessings of clean skin 89}

Wilson's skin 91

Bodily cleanliness in an age of sanitation $\quad 96$

Domesticating skin: popularisation of the microscopical image 101

Clean and healthy skins: education in the tub 105

Soap advertising and the commodification of clean skin 111

Dirty boys and lovely ladies: normative visual language 118 
5 The colours of life Early photography of skin diseases

Early works 128

Extending traditions

Artist and machine: 'la nature prise sur le fait'

Popular photographic conventions

148

Violating the sanctity of the person: dissemination and decency

153

Standardising diseased skin: demarcating professional depiction

6 Conclusion

Bibliography

Nederlandse samenvatting

Curriculum Vitae 


\section{Acknowledgements}

My love for images started in the attic of my parents' house in my early youth. It has been a pleasure to turn this enchantment into a book. I am grateful to the many individuals who have shared this love with me during the years of doing research and writing this book:

For their help and encouragement I am extremely grateful to my supervisors Rob Zwijnenberg en Jo Wachelder. Rob, my promotor, helped me to find my way into the professional academic environment with all its tacit rules. He also never forgot to remind me of the importance of sticking to the main story. Thank you for your guidance.

My copromotor Jo has shown me the importance of inspiration and persistence in historical research. Without his patience, listening, advice in the history of science, and meticulous comments, my work would not have been as complete. Although I have not always made it easy for him with so many horrifying pictures, I thank him for being there for me during my adventure. Together, Rob and Jo formed my true 'academic fathers'. I could not have wished for better supervisors.

Writing this book has not been a solitary endeavour. I want to record my gratitude to many people from diverse fields of research for providing their essential stimulating company in research.

This book has benefited greatly from the discussions and individual exchanges with the members of the NWO-funded Mediated Body research project for getting to know the different ways of dealing with the histories and philosophies of bodies. Bernike Pasveer, Renée van de Vall, Jenny Slatman, Rina Knoeff, Maud Radstake, Miriam van Rijsingen and Babette Müller-Rockstroh have read my work at various stages of development and contributed much to it. Rina, special thanks for helping me find my way in the history of medicine.

The Faculty of Arts and Social Sciences at Maastricht University has been the ideal interdisciplinary stage for feeding and shaping my research. I like to thank the members of the BOTS research colloquium, whose thoughtful comments have made my work stronger. I should particularly mention Geert Somsen, Jens Lachmund, Karin Bijsterveld, Frank Huisman, and Ernst Homburg.

Others both in Holland and abroad have also critically evaluated my work at different times. Their many suggestions have improved my work greatly. I thank John Pickstone, Vladimir Jankovic, Carsten Timmermann, Eddy Houwaart, Toine Pieters, AndreasHolger Maehle and Sebastian Pranghofer.

I thank the members and participants of the WTMC research school for inspiring and provoking workshops and summerschools. The AIO's of the Faculty of Arts and Social Sciences at Maastricht University have always created a great open community. For $\mathrm{PhD}$-soups and fun I thank Sophie, Susan, Vivian, Merel, Maaike, Martijn, Cornelia, Ludo, Julia, Nikki, Thijs, Saskia, Leen, Leentje, Alissa en Serge. A special thanks to Sophie for many lunches and more. 


\section{Acknowledgements}

After leaving Maastricht, I found a warm welcome with my new colleagues at Museum Boerhaave in Leiden. They have provided me with the support and means to finish my thesis in an agreeable manner.

Maud and Babette: what a wonderful gift to spend my years in Maastricht with you by my side. Intellectually stimulating, physically enduring in the gym, but always with great joy, our times were invaluable to me. For sharing good and bad times, making cherished memories, her friendship and warmth; I especially want to thank Maud. I feel honoured to have you here as my paranimf.

To my dear friend Grietsie: I am very grateful for her emotional support and proud that she will be at my side as a paranimf. I also thank my friends Floortje en Andreas for helping me keep at a healthy distance from my research.

I like to thank my family for their faith and trust in me: Lara, Frederik, Suze, their partners and children. My parents have always given me unconditional support and love. Dank jullie wel voor alle onvoorwaardelijke steun.

David: Meeting you has been a gift far beyond any science or book. Thank you with all my heart. Gràcies de tot cor. 


\section{Introduction}

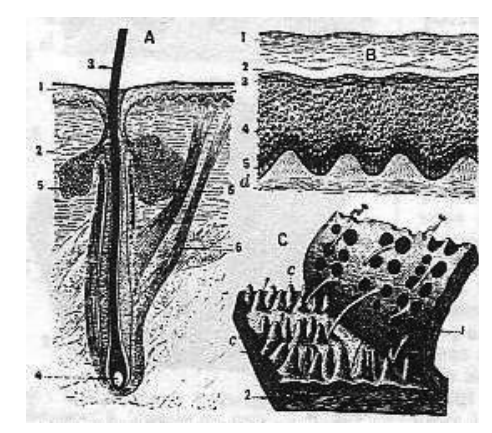

Figure 1.1 Peau. (1897). In C. Augés Nouveau

Larousse illustré. Dictionnaire universel encyclopédique.

Imagine a medical picture of skin. The illustration above might coincide with your visual conception of skin as an organ consisting of some layers of tissue surrounding your body. Yet the depiction of skin is about much more than black and white layers of cells set down on a piece of paper. Depictions of skin are also about the beauty of skin, about horrifying diseases and shame, about the technologies used to reveal the inner secrets of skin and about values for taking care of skin. Designated "one of the most wonderful structures of the human body" skin has been depicted in soap advertisements as a layer of physical and moral cleanliness since the latter half of the nineteenth century. ${ }^{1}$ Physicians have also used attractive and colourful depictions of skin diseases and anatomical structures for various purposes such as theory building and knowledge dissemination. Moreover, in the nineteenth century photographs of people with skin diseases underscored the new awareness of skin as a distinctive surface qualifying identity. Like the illustration above, pictures of skin have mediated between medical science and popular understandings of the body. This book explores the many aspects involved in the medical depiction of skin in history. More particularly it shows how in the nineteenth century pictures of skin were mobilised to amaze, educate, persuade and illuminate a variety of readers in often unexpected ways.

Even the apparently most obvious depictions of skin, like the microscopical picture above, were part of important changes in the conception of skin. For physicians in the nineteenth century skin became an organ with its own diseases, its own typical anatomy 


\section{Chapter 1}

and its own norms for treatment. Most importantly physicians used particular ways to visualise skin depending on the context, their aims and their public. This book analyses how nineteenth-century pictures of skin functioned in relation to new knowledge claims about skin and new investigation and visualisation technologies.

The study of medical depictions draws on questions of knowledge/art relationships. The relationship between knowledge production and pictures is intriguing. The creation of knowledge is deeply entwined with visualisation in pictures on paper. In science and medicine images have been used to investigate bodies, to produce texts about bodies and to transmit knowledge of bodies. ${ }^{2}$ Depicting may even be considered an integral part of knowledge creation. In the microscopical practice of the early nineteenth century for example the microscopist would look through the microscope with one eye while keeping the other eye on the drawing of the specimen of skin, which was done at the same time. ${ }^{3}$ As historians of science have noted, the relationship between science and art is not unilateral but rather complex. ${ }^{4}$ Instead of considering science and art as separate categories, we should rather inquire into the ways in which "objects become visible in culture" ${ }^{5}$ In this book I explore how skin was visualised in nineteenth-century medical culture. This will involve consideration of the often very different functions and uses of depictions of skin as they are involved in knowledge practices and in the appropriation of new investigation and visualisation technologies.

Skin is special. Nowadays considered to be the largest human organ, the skin occupies a remarkable position as mediator between the inner body and the outside world. In the nineteenth century physicians used it as a surface to inquire into the health of their patients, while microscopists examined it as an object to learn about skin physiology and anatomy. The skin was a gateway into the body and disease, as well as a canvas of expression and individuality. In nineteenth-century medicine people's skins were studied, treated, cut, dissected, sutured, scrutinised and depicted over and over again. The resulting pictures of skin were in turn not merely consequences of research, but had lives of their own. Pictures of skin functioned as junctions where (popular) medical knowledge of the skin was defined, delineated, exchanged and communicated.

At the heart of this history are pictures. In the nineteenth century pictures were an integral part of the study of skin diseases, in microscopical studies and in popularisations of skin. They can be found in every shape and size. I analyse dermatological, microscopical and photographic pictures and advertisements about skin. Visualisations

2 See for example: Kemp, M., Wallace, M., \& Londen, H. G. (2000). Spectacular bodies: the art and science of the buman body from Leonardo to now. London: Hayward Gallery Berkeley, CA: University of California Press.

3 Jacquin, J. v. (1829). Bemerkungen über Mikroskope und ihren Gebrauch für Naturforscher. Zeitschrift für Physik und Mathematik, 5, 129-160. Jacquin provides detailed descriptions of the way to draw microscopic specimens. He writes on page 158: "Dann wird (...) mit dem linken Auge ins Mikrokop gesehen, und mit dem rechten gezeichnet." See chapter 3 for an extensive analysis of microscopical depiction of the skin.

4 Baigrie, B. S. (Ed.). (1996). Picturing knowledge: historical and philosophical problems concerning the use of art in science. Toronto: The University of Toronto Press; Jones, C. A., \& Galison, P. (Eds.). (1998). Picturing science, producing art. London/New York: Routledge; Norton Wise, M. (2006). Focus: science and visual culture. Making visible. Isis, 97, 75-82.

5 Jones, C. A., \& Galison, P. (Eds.). (1998), p. 1. 


\section{Introduction}

in medical science indeed deserve attention as "physical, material artefacts mediated by past and present forces". ${ }^{6}$ The historical contextualisation of pictures of skin, as I suggest in this book, demonstrates that pictures are more than simple, straightforward 'illustrations'. Pictures of skin gain a variety of meanings in different scientific, medicocultural contexts of production, dissemination and usage. Technology mattered here. The technological intervention of microscopy and photography changed the depiction of skin in the nineteenth century.

A history of depicting skin may benefit from several fields of study. While both art historians and historians of science and medicine have written about anatomical illustrations and medical pictures of the entire body, pictures of the skin have to date received little attention. ${ }^{7}$ In the post-modern age interest in the body as a subject of cultural analysis has brought the skin to the attention of scholars. ${ }^{8}$ Literary critics, psychologists, art historians and others have begun to analyse the skin in our present culture and in psychic or bodily experience. ${ }^{9}$ By tracing the meanings and understandings of skin in history, these scholars have undone the skin of its self-evident image. In her study Skin: on the cultural border between self and the world (2002), literary historian Claudia Benthien pointed to the changing cultural roles and meanings of skin in science, literature and art since the eighteenth century. She contends that even though medicine has opened the skin and produced new knowledge, the skin has become an increasingly rigid boundary of the body. ${ }^{10}$ Moreover, she shows how conceptualisations of coloured skin, skin as a boundary and skin as a mirror of the soul are moulded in history and culture. Recently, literary scholar Steven Connor underlined the multiple readings of the skin in Western culture in his work The book of skin. By studying a wide variety of medical and literary texts, Connor emphasises the various cultural codifications of the

6 Tucker, J. (2006). The historian, the picture, and the archive. Isis, 97, 111-120. Quoted from p. 112.

7 On medical illustration see for example: Kemp, M. (1993). The mark of truth: looking and learning in some anatomical illustrations from the Renaissance and eighteenth century. In W. F. Bynum \& R. Porter (Eds.), Medicine and the five senses (pp. 85-121). Cambridge: Cambridge U.P.; Petherbridge, D., \& Jordanova, L. (1997). The quick and the dead: artist and anatomy. S.l.: The South Bank Center; Porter, R. (2001). Bodies politic: disease, death and doctors in Britain, 1650-1900. London: Reaktion Books.

8 For post-modern essays of the body see for example the Zone series on the body edited by Jonathan Crary, Michel Feher, Hal Foster, and Sanford Kwinter: Feher, M., Naddaff, R., \& Tazi, N. (Eds.). (1989). Fragments for a history of the human body. New York: Urzone; Crary, J., \& Kwinter, S. (Eds.). (1992). Incorporations. New York: Zone. On the photographic depiction of the human body see for example: Ewing, W. A. (1994). The body: photoworks of the human form. London: Thames and Hudson. On the history of parts of the body see: Benthien, C., \& Wulf, C. (2001). Körperteile: eine kulturelle Anatomie (Orig.-Ausg. ed.). Reinbek bei Hamburg: Rowohlt Taschenbuch Verlag. For more recent work on the early modern preoccupation with the human body see: Egmond, F., \& Zwijnenberg, R. (Eds.). (2003). Bodily extremities: preoccupations with the human body in early modern European culture. Aldershot: Ashgate.

9 See: Anzieu, D. (1989). The skin ego: a psychoanalytic approach to the self (C. Turner, Trans.). New Haven, Conn: Yale University Press; Joost, T., \& van Everdingen, J. J. E. (Eds.). (1996). Omtrent de huid. Cultuurhistorische verkenningen. Amsterdam/Overveen: Boom/Belvédère; Benthien, C. (2002). Skin: on the cultural border between self and the world. (T. Dunlap, Trans.). New York: Columbia University Press; Pazzini, K.-J. (2001). Haut: Berührungssehnsucht und Juckreiz. In C. Benthien \& C. Wulf (Eds.), Körperteile: eine kulturelle Anatomie (pp. 153-173). Reinbek bei Hamburg: Rowohlt Taschenbuch Verlag; Hanke, C., \& Nössler, R. (Eds.). (2003). Haut. Tübingen: konkursbuch Verlag Claudia Gehrke; Connor, S. (2004). The book of skin. Ithaca, New York: Cornell University Press.

10 Benthien, C. (2002), p. 1. 


\section{Chapter 1}

skin from the marking of the skin to scenes of religious anointment. ${ }^{11}$ Cultural studies of skin have therefore stressed the idea of the skin as a cultural subject shaped by history.

My approach in this book however is to investigate skin as a visual subject of medical history. Both historians of science and medicine and art historians have so far largely neglected the depiction of skin. ${ }^{12}$ Traditionally, historians of dermatology, themselves often dermatologists by profession, have been concerned with knowledge practices around the diseased skin. They have provided us with exciting stories of the main figures in dermatology, emphasising their 'discoveries' and contributions to the knowledge of skin diseases. ${ }^{13}$ Pictures of skin diseases are therefore often considered detached from their original context to illustrate current understandings of dermatology. However, by taking a pragmatic approach, stressing the practical uses and functions of pictures of skin in knowledge practices in medicine, I show how a contextual history of the depiction of skin brings technologies, medical knowledge and visual cultures together. New ways of knowing skin were combined with new ways of depicting the skin to form a visual language of skin.

\section{Learning about visual language: characteristics and dynamics}

In our culture we are constantly confronted with all sorts and types of pictures of the human body. Medical and scientific pictures seem to rule just as much in places where knowledge about the body is made or used professionally as they do in public realms. ${ }^{14}$ Indeed, the intriguing role of images in science and medicine has been at the centre of many analyses. Scholars from various disciplines have approached pictures predominantly with a focus on the problem of 'representation'. According to Ian Hacking, representation is the key activity of human beings: "Human beings are representers. Not homo faber, I say, but homo depictor. People make representations. (...) People make likenesses. They paint pictures, imitate the clucking of hens, mould clay, carve statures, and hammer brass. Those are the sorts of representations that begin to characterize human beings". ${ }^{15}$ The issue of representation, then, questions the relationship between an object in the world and its sign, visual or otherwise. In the case of visual representation the relationship between the object and its sign may seem clear-cut, but this straightforwardness is deceptive. ${ }^{16}$ Depending on the philosophical

11 Connor, S. (2004): Chapter 3: Disfiguring, and Chapter 7: Unction.

12 An important exception is the work by art historian Mechtild Fend: Fend, M. (2005). Bodily and pictorial surfaces: skin in French art and medicine, 1790-1860. Art History, 28(3), 311-339.

13 See for example: Pusey, W. A. (1979). The history of dermatology. New York: AMS Press; Crissey, J. T., \& Parish, L. C. (1981). The dermatology and syphilology of the nineteenth century. New York, N.Y: Praeger division of CBS Educational and Professional Publishing.

14 On the dissemination of medical images to a popular audience see for example: Dijck, J. van (2005). The transparent body: a cultural analysis of medical imaging. Seattle, WA: University of Washington Press.

15 Hacking, I. (1983). Representing and intervening. Cambridge: Cambridge University Press, p. 132. Italics in original.

16 Hall, S. (1997). Representation: cultural representations and signifying practices. London: Sage, p. 20. 


\section{Introduction}

understanding of visual representation, for example, ideas about the ontological status of the object represented, the social construction of the representation itself or the accuracy of the representation may diverge. ${ }^{17}$ In the case of the depiction of the skin a focus on representation would result in questions such as: What is the relationship of the actual skin to its illustrations? Does skin exist outside its depiction? The problem of representation therefore often revolves around the 'what' in representation. However, it is not my intention to discuss this representational dimension of the depiction of skin: I want to study the functions and uses of pictures in practice. How did pictures of skin function in processes of scientific investigation and the making of medical knowledge? How did pictures take part in the dissemination of knowledge on skin and in the appropriation of imaging technologies in popular contexts? One way of partially avoiding the debates about representational reference is to look at visualisation as a practice. In an article on representation in scientific practice philosopher and anthropologist of science Bruno Latour has even described visualisation as part of inscription practice as science. ${ }^{18}$ However, the work on illustrations in science studies has been criticised for a lack of attention to the contents of the pictures themselves. ${ }^{19}$ I want to avoid entering into the ongoing discussion about the implications of the concept of representation by focusing on pragmatic questions that ask how depictions are used and functioned in practice and how they are subject to historical change.

In his review of the production of scientific images science studies scholar Michael Lynch noted the gains of a pragmatic analysis of visualisation in science. He pointed to "the useful analogy between the pragmatic uses of linguistic expressions and the various uses of graphs, models, and pictures in scientific work" ${ }^{20} \mathrm{He}$ proposed to "disrupt traditional obsessions with representation by investigating an array of pictorial and graphic 'games". ${ }^{21}$ Such a pragmatic analysis allows for an appreciation of diverse practices and uses of visualisation in science. Lynch stresses that this approach may do away with endless debates, such as the realist-constructivist debate, which seem to arise when heterogeneous ways of visualisation in scientific practice are forced "into a single conceptual framework". ${ }^{22}$ In this book I use the suggested pragmatic approach in order to analyse the visual culture of skin in nineteenth-century medicine.

Apart from the problem of representation, there is another dilemma that arises in studies of the depiction of the skin: the word-image dichotomy. So far, art historians,

17 See: Tibbets, P. (1990). Representation and the realist-constructivist controversy. In M. Lynch \& S. Woolgar (Eds.), Representation in scientific practice (pp. 69-84). Cambridge, Mass: The MIT Press.

18 See Latour, B. (1990). Drawing things together. In M. Lynch \& S. Woolgar (Eds.), Representation in scientific practice (pp. 19-68). Cambridge/London: The MIT Press; Rheinberger, H.-J. (1994). Essay Review: Representation(s). Studies in History and Philosophy of Science, 25(4), 647-654. Rheinberger on Latour p. 650: "No one else has made this drastic move from 'representation in scientific practice' to 'inscription as scientific practice.".

19 Pang, A. S.-K. (1997). Visual representation and post-constructivist history of science. Historical Studies in the Physical and Biological Sciences, 28(1), 139-172; p. 143.

20 Lynch, M. (1998). The production of scientific images: vision and re-vision in the history, philosophy, and sociology of science. Communication and Cognition, 31(2-3), 213-228; p. 217.

21 Idem. Lynch's use of the term 'games' refers to Ludwig Wittgenstein's work on the pragmatic uses of languages in different language games.

22 Lynch, M. (1998), p. 217. 


\section{Chapter 1}

cultural studies scholars and historians of dermatology have approached pictures of the skin in science and medicine from two extremes. On the one hand historians of dermatology have treated illustrations of skin diseases, if noticed at all, as "after images of verbal ideas". ${ }^{23}$ They understand illustrations mostly as subordinate to texts about skin diseases. Exceptions to this subordination include catalogues of exhibitions and overenthusiastic glorifications of dermatological illustrations by non-historians. Many collections of dermatological images have in fact appeared as catalogues. ${ }^{24}$ Because of their purpose of display only, most of these works remain at a rather descriptive level, apart from exceptions such as the work of Franz Ehring. ${ }^{25}$ His exhaustive and precise review of dermatological imaging provides a basis for the analysis of links between the images and their contexts. In a paper on early dermatological illustration historian of dermatology John Crissey also described illustrations of skin diseases in relation to the text. ${ }^{26}$ Yet Crissey provides the illustrations with a decorative role. On the other hand, art historians and cultural studies scholars have considered dermatological images as "self-sufficient works of art", detached and isolated from their context of (knowledge) production, use and function. ${ }^{27}$

In this book I seek to escape from these extremes that seem to struggle with a word-image dichotomy, where attention is focused on either the image or the text. I consider the concept of visual language apt to "bridge the gap between word and image". ${ }^{28}$ In 1976 historian of science Martin Rudwick introduced the concept of visual language to understand the historical role of images in geology. ${ }^{29}$ His seminal article on the emergence of a 'visual language' for geological science has set the agenda for many studies on visual representation in the history of science. Rudwick used the concept to draw attention to the visual modes of communication between scientists. Illustrations are part of a visual communication that has to be learned and which changes over time:

23 I borrowed this term from art historian Samuel Edgerton in: Edgerton, S. Y. (1985). The Renaissance development of the scientific illustration. In J. W. Shirley \& F. D. Hoeniger (Eds.), Science and the arts in the Renaissance (pp. 168-197). Washington, London, Toronto: Associated University Presses; p. 168.

24 See for example: Thyresson, N. (1986). Dermatology through the centuries: an exhibition from the Waller Collection. Uppsala, Reprocentralen HSC.

25 Ehring, F. (1989). Hautkrankheiten: 5 Jahrhunderte wissenschaftlicher Illustration. Stuttgart: Fischer Verlag. For another extraordinary collection on skin see: Zeuch, U. (Ed.). (2003). Verborgen im Buch, verborgen im Körper: Haut, zwischen 1500 und 1800. Wiesbaden: Harrassowitz.

26 Crissey, J. T. (1951). Early dermatologic illustration. A.M.A. Archives of Dermatology and Syphilology, 64, 417424.

27 I borrowed this term from: Jacyna, L. S. (1998). Pious pathology: J.L. Alibert's iconography of disease. In M. Gijswijt-Hofstra \& R. Porter (Eds.), Constructing Paris medicine (pp. 185-219). Amsterdam: Rodopi; p. 187. For art historical work on dermatological illustrations see for example: Dahm, S. (1981). Frühe Krankenbildnisse: Alibert, Esquirol, Baumgärtner. Köln: Forschungsstelle des Instituts für Geschichte der Medizin der Universität zu Köln.

28 Brian Baigrie pointed to the fact that other historians of science and art have "attempted to bridge the gap between word and image by suggesting that scientific illustration involves a kind of visual language". Introduction to the edited volume: Baigrie, B. S. (1996), p. xxiv.

29 Rudwick, M. J. S. (1976). The emergence of a visual language for geological science 1760-1840. History of science, 14, 149-195. 


\section{Introduction}

In other words, a geographical map - or any other visual diagram in geology - is a document presented in a visual language; and like any ordinary verbal language this embodies a complex set of tacit rules and conventions that have to be learned by practice. Again, like an ordinary language, these visual means of communication necessarily imply the existence of a social community which tacitly accepts these rules and shares an understanding of these conventions. ${ }^{30}$

Rudwick's analysis of a visual language in geology was inspired by the art historical work of Ernst Gombrich. In Art and illusion (1960), Gombrich used the term visual language to argue that artists make use of pictorial formulas, thereby constructing a relational model instead of producing a faithful record: "The form of a representation cannot be divorced from its purpose and the requirements of the society in which the given visual language gains currency". ${ }^{31}$ Rudwick, then, took the concept into the history of science and made an analysis of the application of visual language as a non-verbal means of communication. The development of geology as a new science was accompanied by "the construction of a visual language that was appropriate to the subject-matter of the science, and which could complement verbal descriptions and theories by communicating observations and ideas that could not be expressed in words" ${ }^{32}$

Following Rudwick, other historians of science took note of the concept of visual language in analyses of illustration in the scientific disciplines of zoology and chemistry. ${ }^{33}$ Art historian Samuel Edgerton also made a plea for the historical treatment of scientific illustration as "a unique form of pictorial language, with its own "grammar and syntax"; that is, symbols and conventions conveying information just as do words and sentences". ${ }^{34}$ Historian of science David Knight stressed the treatment of scientific illustrations in relation to their context in his article on scientific theory and visual language. ${ }^{35}$ He noted how much scientific illustrations depend on their context by pointing to the relativity of visual language: "scientific language and the concerns associated with it changes, whether it be visual or ordinary language." ${ }^{36}$ It is precisely in these kinds of dynamics of visual language that I am interested when regarding the depiction of skin in the nineteenth century.

In using the term 'visual language' I do not want to draw a strict one-to-one relationship between knowledge and pictures. Historian of science Renato Mazzolini stressed the importance of non-verbal sources in science as means for the communication of

30 Rudwick, M. J. S. (1976), p. 151.

31 Gombrich, E. H. (1960). Art and illusion: a study in the psychology of pictorial representation (1st ed.). London: Phaidon Press, p. 90.

32 Rudwick, M. J. S. (1976), p. 177. Italics in original.

33 The concept visual language has been used to analyse illustrations in zoology and chemistry: Blum, A. S. (1993). Picturing nature: American nineteenth-century zoological illustration. Princeton N.J.: Princeton U.P.; Knight, D. M. (1993). Pictures, diagrams and symbols: Visual language in nineteenth-century chemistry. In R. G. Mazzolini (Ed.), Non-verbal communication in science prior to 1900 (pp. 321-344). Firenze: Olschki; Knight, D. M. (1996). Illustrating chemistry. In B. S. Baigrie (Ed.), Picturing knowledge: historical and philosophical problems concerning the use of art in science. (pp. 135-163). Toronto etc.: The University of Toronto Press.

34 Edgerton, S. Y. (1985), p. 168.

35 Knight, D. M. (1985). Scientific theory and visual language. Acta Universitatis Upsaliensis, Series 22, 106-124.

36 Ibid., p. 124. 


\section{Chapter 1}

information. ${ }^{37}$ However, as my study reveals, the picture - as a medium - can also change knowledge and introduce or leave out information without human intention. Or, as Bruno Latour puts it: "information is never simply transferred, it is always radically transformed from one medium to the next." 38 I do not therefore focus on the merely referential aspects of the visual language (what does a visual symbol represent?), but analyse the uses and functions of pictures as mediators, in visual language. Moreover, I will not use the term 'pictorial convention' in the art historical sense. This term seems to suggest too much of a fixed, descriptive idea of pictorial styles that are imposed from outside. Instead, I show how the dynamics in visual language of skin allows for variable meanings and functions of pictures between the realms of science, medicine and popular culture.

My approach in this book is an application of the concept of visual language as a tool for investigating the multiple functions and uses of pictures. Not only scientific pictures, but also medical and popular illustrations of skin can be studied using this concept. I will show how the concept of visual language allows for a pragmatic analysis of the uses and functions of pictures of the skin in various contexts. Moreover, the concept of visual language may do away with the need to fit all illustrations involved with knowledge production inside one particular framework. In this respect I follow Martin Kemp, who does not opt for "a grand, unifying theory" for scientific illustration:

The relationship between illustration and visualization seems quite different in the various sciences, though we can frequently observe intricate conjunctions in the structure of metaphor, analogy, and 'aesthetics' that is used to locate a specific field of study within its broader intellectual, theological, and social nexus. I have to say, as far as I am concerned, the lack of conformity to a grand theory makes matters more interesting to me as a historian of visual representation than less so. ${ }^{39}$

There is no straightforward story to be told about the scientific and medical depiction of the skin in the nineteenth century. Instead, my approach appreciates the different functions of visualisation in the domains of science, medicine and popular culture.

By looking at the dynamics of visual language of skin in and between the domains of science, medicine and popular culture, my approach takes the study of pictures of the skin one step further than previous analyses. Although the concept 'visual language' has been used for the study of scientific illustrations, I want to broaden it to include an analysis of medical images and popular pictures such as advertisements and their interactions. The broadening of this scope is significant, since a lack of attention has been noted in the contextual treatment of illustrations in medical history. ${ }^{40}$ Cultural

37 Mazzolini, R. G. (Ed.). (1993). Non-verbal communication in science prior to 1900. Firenze: Olschki, preface.

38 Latour, B. (1998). How to be iconophilic in art, science, and religion. In C. A. Jones \& P. Galison (Eds.), Picturing science, producing art (pp. 418-440). London/New York: Routledge; p. 425.

39 Kemp, M. (1996). Temples of the body and temples of the cosmos: Vision and visualization in the Vesalian and Copernican revolutions. In B. S. Baigrie (Ed.), Picturing knowledge: historical and philosophical problems concerning the use of art in science (pp. 41-85). Toronto: University of Toronto Press; p. 83.

40 Exceptions to this general statement are the works by Roy Porter and Sander Gilman in the Picturing History series published by Reaktion: Gilman, S. L. (1995). Health and illness: images of difference. London: Reaktion Books; Porter, R. (2001). 


\section{Introduction}

historian Sander Gilman has argued that medical historians have often treated medical illustrations as either mere illustrations or 'high art'. ${ }^{41}$ The dichotomised historical treatment of images of skin, then, is in keeping with Gilman's diagnosis of the use of images in the history of medicine. By applying the concept of visual language to medical pictures of the skin, I am agreeing with Gilman's approach to medical images by looking at the various functions of the "vocabulary of images". ${ }^{42}$

\section{Exploring the visual history of skin in medicine}

The main argument holds that the depiction of skin has changed meanings of skin. In four chapters I identify key ways in which pictures of skin have functioned in processes of knowledge production and dissemination, scientific microscopical investigations, the plea for skin cleanliness and the introduction of photography as a new visualisation technology in medicine. The reader is taken on a journey through various scenes of depiction of skin in roughly chronological order. By analysing the pictures themselves, as well as accompanying primary medical and scientific textual sources, I show how, in four episodes over the course of the nineteenth century, pictures of the skin shaped new meanings of skin in the visual culture of medicine. Each episode explores a different aspect of the visual language of skin: pictorial vocabularies of skin diseases (chapter two), uses of pictures in knowledge creation on skin (chapter three), normative dimensions of pictures of skin (chapter four) and the function of pictures of skin in dynamics between the public and medical professional arena (chapter five).

Chapter two discusses the relationship between classifications of skin diseases and depictions. I examine how knowledge and pictures interacted in French and British medical books on skin diseases between 1790 and 1840. My approach counters existing literature on early depictions of skin diseases by concentrating on the relationship between contemporary knowledge production of skin diseases and ways of depiction. Instead of treating pictures as illustrations, I take depiction as a key activity in theory building on skin diseases. In the early decades of the nineteenth century physicians developed two distinctly different ways of depicting diseased skin. Both typified fragments of skin and the whole patient was used to visualise diseased skin. The coloured illustrations of skin diseases that were published in the early decades of the nineteenth century are inextricably tied up with visual knowledge of skin diseases.

In chapter three I turn to the depiction of the smaller structures of healthy skin in the context of microscopic practice in Germany and France between 1820 and 1850. A case study of the illustrations of skin pores shows how illustrations fulfilled multiple functions in microscopical investigation processes. Pictures played an important rhetorical role in microscopical research. Moreover, the historical development in the depiction of the skin pores exemplifies how the skin was visually redefined from a permeable layer into 


\section{Chapter 1}

a thick boundary organ. Building on previous work about changing body conceptions in the eighteenth century, I examine the changing meaning of the skin in microscopical depictions. I argue that microscopical work on skin in the first half of the nineteenth century produced the image of an anatomically thickened, complex skin. The visual articulation of the interior of the skin itself revealed new ideas about the interactions between the inner body and its outer milieu.

While chapter three is about the scientific use of visual language of skin, chapter four focuses on the depiction of skin cleanliness in British soap advertisements between 1840 and 1900. This chapter considers the role of pictures in the sanitary age of bodily cleanliness as a new morale. Several editions of the popular book Healthy skin by the British physician Erasmus Wilson are analysed to show how a concept of skin cleanliness as a new morale was constructed in the context of public health. The virtues of skin cleanliness were expressed visually in the late Victorian soap advertising campaign for Pears' soap. By examining soap advertisements of 'dirty boys' and lovely ladies, I argue that a highly normative visual language of clean skin accompanied the popularisation of medical and scientific knowledge of the skin in Great Britain in the second half of the nineteenth century.

Chapter five is concerned with the appropriation of photography as a new way of visualising diseased skin. By looking at early British, French and American photographic atlases of skin diseases, I trace the emergence of medical photographical standards in the depiction of the body. I demonstrate how the visual language of diseased skin, as discussed in chapter two, changed with the introduction of photography. The combination of mechanical reproduction and manual colouring makes the early photographic atlases in dermatology unusual and profoundly 'hybrid' works. The appropriation of photography as a new visualisation technology posed new dilemmas for physicians. They had to find a way to demarcate professional photography from popular photographs. As in all the chapters, this case is used to provide an analysis of the changing relationships between pictures, medical and scientific knowledge of skin, illustration techniques and particular medical and cultural practices.

In the concluding chapter I further discuss the implications and opportunities of understanding pictures of skin as visual language. Pictures reflect more than mere illustrations. Pictures of skin reflect the production and dissemination of knowledge, the popularisation of that knowledge and the demarcation of knowledge in professional contexts from the popular realm. They provide a fresh entry into the history of our bodily cover. Exploring the depiction of skin means exploring changing concepts of skin. 


\title{
Surface of recognition
}

\section{A visual vocabulary of diseased skin}

\begin{abstract}
There is another circumstance, however, which renders the diseases of the skin equally capable of methodological classification with the other objects of natural history, namely, the facility of representing them by drawings. ${ }^{1}$
\end{abstract}

A knowledge of the elementary forms under which they [the diseases of the skin] appear is a necessary preliminary to the study of the whole of their stages; a strange alphabet has to be learned before the page of information can be approached. ${ }^{2}$

Like animals, flowers and minerals, in the early nineteenth century skin diseases were regarded as being equally suitable for classification and visualisation in illustrations. As with natural history illustration, the depiction of diseased skin involved the development of certain pictorial conventions. In similar fashion to, for example, zoological illustrations in the nineteenth century, knowledge production on skin diseases is related to typical ways of depiction. ${ }^{3}$ Until the late eighteenth century illustrations of skin diseases were not commonly found in medical books. However, from the early nineteenth century onwards physicians concerned with skin diseases started to develop specific visual arrangements of them in pictures. Slowly, the building blocks for a visual language of diseased skin were created. This chapter analyses how such a visual language took shape in Great Britain and France between 1790 and 1840.

Knowledge production and ways of depiction are strongly related. Pictures of skin diseases started to proliferate from around 1800 . They were not simply illustrative for newly introduced arrangements of skin diseases, but became crucial in knowledge construction and dissemination. Students were able to learn about the visual characteristics of skin diseases at a single glance. Depictions of skin diseases were eventually standardised and this made communication among physicians easier. This chapter shows how pictures of

1 Bateman, T. (1817). Delineations of cutaneous diseases: exhibiting the characteristic appearances of the principal genera and species comprised in the classification of the late Dr. Willan; and completing the series of engravings begun by that author. London: Longman, Hurst, Rees, Orme, and Brown, p. iv.

2 Green, J. (1838). A practical compendium of the diseases of the skin. Philadelphia: A. Waldie, p. VI. Quoted in Crissey, J. T., \& Parish, L. C. (1981), p. 38.

3 Historian Ann Shelby Blum has shown how pictorial conventions emerged in American zoological illustration practices in the nineteenth century. In her work, she relates different approaches and meanings of natural history and animals to typical ways of depiction. A Linnaean system of classification for example, was accompanied by a certain style of illustration that emphasized morphology. See Blum, A. S. (1993). Picturing nature: American nineteenth-century zoological illustration. Princeton N.J.: Princeton U.P. 


\section{Chapter 2}

skin diseases emerged that were inextricably bound up with theories and classifications of skin diseases and how pictures of skin diseases came to matter in medical contexts. Hardly any consideration has been given to pictorial aspects of early nineteenth-century dermatological books in the context of knowledge development. The iconography in books on skin diseases by the famous French physician Jean-Louis Alibert (1768-1837) has to date been a most popular subject among authors in various fields. ${ }^{4}$ Medical historian Jacyna's analysis of Alibert's illustrations stands out from other art historical and cultural studies analyses of Alibert, because Jacyna places pictures in the context of Alibert's writings. ${ }^{5}$ Yet even Jacyna does not account for the specific relationship between early depictions of skin diseases and nosographical aspirations of knowledge production on skin diseases in a broader context. Historians of dermatology on the other hand have paid a great deal of attention to emerging nosologies of skin diseases, but have disregarded the role of illustrations. ${ }^{6}$ I suggest moving beyond the one-sided focus on one famous man, or one modern classification, or one national context. Only an analysis of different pictures of skin diseases from different national contexts may start to reveal the kind of ingredients for a visual language emerging in early nineteenth-century Europe.

This chapter examines how a 'visual language' of diseased skin emerged in the early decades of the nineteenth century. Following historian of science Martin Rudwick, we see how a "complex set of tacit rules and conventions" emerged to form a visual language for the depiction of skin diseases. ${ }^{7}$ More specifically, we follow how a particular vocabulary for pictures of skin diseases materialised in the early decades of the nineteenth century. Physicians developed specific ways of depicting skin diseases in an ongoing exchange with newly developed arrangements and nomenclature. Initially, two competing ways of classifying skin diseases emerged in Great Britain and France (Paris). Each classification carried its own theory and diagnostics and was accompanied by its own way of depiction. The two styles constituted the building blocks of a visual language that consisted of a merger of the two styles. To explore the construction of that visual language of skin diseases, illustrations from British and Parisian works on skin diseases will be discussed in relation to their nosological grounding. When skin as a diseased surface became interesting for physicians to observe, to 'read' and to classify, depictions became necessary as a visual language.

The construction of a visual language of diseased skin is examined in works on skin diseases by British and French physicians between 1790 and 1840. An investigation of pictures in the books of two influential physicians shows how the ingredients for the depiction of diseased skin emerged in particular localised knowledge practices. I will first look at the way pictures became part of books on skin diseases by the British physician

4 See: Dahm, S. (1981).; Stafford, B. M. (1991). Body criticism: imaging the unseen in Enlightenment art and medicine. Cambridge, MA: The MIT Press, pp. 300-305; Benthien, C. (2002), pp. 54-57.

5 Jacyna, L. S. (1998).

6 See Pusey, W. A. (1979); Crissey, J. T. \& L. C. Parish (1981); Tilles, G., \& Wallach, D. (1989). Histoire de la nosologie en dermatologie. Ann. Dermatol. Venereol., 116, 9-26; Tilles, G., \& Wallach, D. (2002). Les doctrines en dermatologie. In D. Wallach \& G. Tilles (Eds.), La dermatologie en France (pp. 63-76). Toulouse: Éditions Privat. The work by Ehring is an exception: Ehring, F. (1989).

7 Rudwick, M. J. S. (1976), p. 151. 


\section{Surface of recognition}

Robert Willan (1757-1812). Willan explicitly brought illustrations into play for his powerful and influential classification of skin diseases. His work would set the basis for the focus on the local form - the topical morphology - in the depiction of diseased skin. In a subsequent section the historical roots of Willan's classification are discussed. Next, I point to the importance of illustrations in the dissemination of knowledge on skin diseases by following Willan's approach to Paris, where several physicians appropriated Willan's classification and depiction. In Paris, however, we find that Jean-Louis Alibert also produced an important classification of skin diseases accompanied by yet another way of depiction. In the latter part of the chapter I concentrate on Alibert's clinical depiction of skin diseases in the 'whole patient'. Both Willan's depiction of the local form and Alibert's clinical depiction were to become the building blocks of a visual language of diseased skin in the nineteenth century. In the last section we see how a story of competing nosologies led to a repertoire of local and clinical ways of depiction forming a visual language for modern dermatology.

\section{Classification and visualisation}

Early illustrations of skin diseases were closely intertwined with systems of classification. Works on skin diseases illustrated with hand-coloured engravings started to appear in Great Britain and France between 1790 and 1830. The British physician Robert Willan (1757-1812) published a very important book with coloured images of skin diseases in $1798 .^{8}$ More than before pictures became part of the theory and classifications of skin diseases. Many dermatologists with an interest in the histories behind their trade regard the work of Robert Willan as the foundation of modern dermatology. ${ }^{9}$ His approach to and classification of skin diseases are seen as the first manifestation of modern professional dermatological terminology. Yet Willan's illustrations of skin diseases are notably part of the nosological developments of his time. His work marks a transition towards a more prominent role for pictures in medical writings on skin disease. In this section we see how, in Willan's work, early illustrations of skin diseases and classifications emerged as knowledge claims closely linked to each other. His work initiated one of the crucial pictorial ingredients for a visual language of skin diseases in the nineteenth century.

Willan started his descriptions of skin diseases in 1798. The first part of Description

8 Willan, R. (1798). Description and treatment of cutaneous diseases. Order 1. Papulous eruptions on the skin, coloured plates. London. On Robert Willan and his work see for example: Lane, J. E. (1926). Robert Willan. Archives of Dermatology and Syphilology, 13(6), 737-760; Haldin-Davis, H. (1931). The foundations of British dermatology. Annals of Medical History, 3, 368-386; Booth, C. C. (1968). Robert Willan MD FRS FSA. The British Journal of Dermatology, 80, 459-467; Pusey, W. A. (1979), p. 61-67; Tilles, G., \& Wallach, D. (1999). Robert Willan and the French Willanists. British Journal of Dermatology, 140(6), 1122-1126; Voorde, K. van de, Regenmortel, N. van, \& Hee, R. van (2003). Robert Willan (1757-1812) en de systematiek van de dermatologie. Geschiedenis der Geneeskunde, 9(5), 260-269.

9 See Lane, J. E. (1926), p. 738; Haldin-Davis, H. (1931), p. 369; Pusey, W. A. (1979), p. 61; Crissey, J. T. and L. C. Parish (1981), p. 26; Tilles, G. \& D. Wallach (2002), p. 65. 


\section{Chapter 2}

and treatment of cutaneous diseases appeared that year. ${ }^{10}$ Three other parts with engraved plates were published in 1801, 1805 and 1808 and were subsequently assembled into a single volume in 1808: On cutaneous diseases. ${ }^{11}$ On cutaneous diseases was the first of two volumes on skin diseases and contained descriptions and illustrations of Willan's first four 'Orders' of skin diseases. Willan ultimately divided skin diseases into eight orders, with subdivisions into Genera, Species and Varieties. ${ }^{12}$ On cutaneous diseases was translated into German and an American edition was published in $1809 .{ }^{13}$ The planned second volume of On cutaneous diseases describing the remaining four orders would never appear, as Willan died on Madeira in $1812 .{ }^{14}$

Willan chose to focus on skin diseases when he was working as a general physician. When he published the first part of Description and treatment of cutaneous diseases, Willan, who had been born into a Quaker family, was working as a physician at the Public Dispensary in Carey Street (London). ${ }^{15} \mathrm{He}$ was admitted to the Royal College of Physicians in 1785 and in 1790 received the prestigious Fothergillian Gold Medal from the Medical Society of London in honour of his novel plan to (re)arrange and describe cutaneous diseases. ${ }^{16}$ Apart from his work on skin diseases, Willan also lectured on the principles and practices of medicine and wrote on public health in London. ${ }^{17}$ Nonetheless, Willan was and still is best remembered for his illustrated work on skin diseases. ${ }^{18}$ His popular approach to skin diseases was adopted in medical centres in cities throughout continental Europe in the first half of the nineteenth century.

Willan himself was not responsible for the widespread success of his classification of skin diseases. After Willan's early death, his pupil and personal friend Thomas Bateman published a format of the classification that was spread between 1813 and 1850. Bateman (1778-1821) purchased the copyrights of Willan's books, his watercolour drawings and engravings. ${ }^{19}$ He had succeeded Willan as physician to the Carey Street Hospital

Willan, R. (1798).

11 Willan, R. (1808). On cutaneous diseases. Vol. I. London: J. Johnson. The history of the first volume of On cutaneous diseases is rather complex. The contents and illustrations of the compiled work On cutaneous diseases does not exactly match to the available editions of the separate first volume of Description and treatment of cutaneous diseases. For a detailed description of the complex yet subtle events surrounding the publication of the volumes and editions see: Beswick, T. S. L. (1957). Robert Willan: The solution of a ninety-year-old mystery. Journal of the History of Medicine and allied Sciences, 12, 349-367.

12 For a discussion of the differences between Willan's initial arrangements see appendices A-D in: Beswick, T. S. L. (1957), pp. 363-365. Like other authors, I take Bateman's referral to "the eight orders of Dr. Willan” as basic principle, see: Bateman, T. (1813), p. xi; Pusey, W. A. (1979), p. 67; Tilles, G. and D. Wallach (1999), p. 1123.

13 See 'Willan's writings' in: Lane, J. E. (1926), pp. 755-757.

14 On Willan's biography see: Lane, J. E. (1926), pp. 752-755.

15 MacCormac, H. (1933). At the public dispensary with Willan and Bateman. The British Journal of Dermatology and Syphilis, 45, 385-895.

16 Lane, J. E. (1926), p. 740.

17 Ibid., p. 745.

18 Both contemporaries and present-day authors and dermatologists remember Willan for his work on skin diseases. See for example: Bateman, T. (1812). A biographical memoir of the late Dr. Willan. Edinburgh Medical and Surgical Journal, 8, 502-512; Beswick, T. (1957), p. 349; Staughton, R. C. D., \& Smith, M. (2000). Choosing a dermatological hero for the Millennium. Clinical and Experimental Dermatology, 25(1), 82-95.

19 On Bateman see: Levell, N. J. (2000). Thomas Bateman MD FLS 1778-1821. British Journal of Dermatology, 143, 9-15. 
in 1804 and now took upon himself the task of advocating and extending Willan's intellectual legacy. Building on the work of Willan, Bateman published his pocketsize Practical synopsis of cutaneous diseases according to the arrangement of Dr. Willan in $1813 .{ }^{20}$ It was translated into at least four foreign languages and became enormously popular, as the 11 editions show. ${ }^{21}$ Later, Bateman also released the promised second volume of Willan's arrangement in 1817, under the extensive title Delineations of cutaneous diseases: exhibiting the characteristic appearances of the principal genera and species comprised in the classification of the late Dr. Willan; and completing the series of engravings begun by that author. ${ }^{22}$ For this volume Bateman used the original drawings by Willan and had them engraved by Stewart, while adapting some of the original plates from the first volume. ${ }^{23}$ In the hands of Bateman Willan's arrangement and visual representation of skin diseases came to the attention of a much wider audience. Dermatologist Nick Levell has even argued that "without Bateman, Willan's full classification might never have been brought to the attention of the world". ${ }^{24}$ After the publication of Bateman's Synopsis, Willan's (adapted) classification of skin diseases also became known in Europe as the Willan-Bateman classification for arranging and naming skin diseases. ${ }^{25}$ Within just a few decades the practices of visualising, recognising and treating skin diseases had changed profoundly. New images of diseased skin dominated in Europe.

In the Willan-Bateman approach skin diseases are defined according to their morphological appearance - the form of the diseased skin. In On cutaneous diseases Willan proposed to bring order to the chaos of preceding classifications and skin disease nosology. He argued that earlier classifications were "artificial" and "inconsistent". ${ }^{26}$ Some authors reduced all the diseases to two or three types and others would name every new form or appearance, leading to a pandemonium of names for skin diseases. Bateman in his Synopsis later stated that "the words Leprosy, Scurvy, Herpes, Scabies, Dartres (...) have become so indefinite, as to be merely synonyms of cutaneous disease" ${ }^{27}$ Willan had set himself the following tasks: to "fix the sense of the terms employed by proper definitions", to "constitute general divisions or orders of disease, from leading and peculiar circumstances in their appearance, and to describe at large their specific

20 Bateman, T. (1813). A practical synopsis of cutaneous diseases according to the arrangement of Dr. Willan, exhibiting a concise view of the diagnostic symptoms and the method of treatment. London: Longman.

21 See Booth, C. C. (2000), p. 85. As far as known, Bateman's Synopsis was translated into German (1815), French (1820), Italian (1822), and Swedish (1838). The work went through eleven editions between 1813 and 1850, among which two American printings. Also, the emperor of Russia had ordered some copies and offered Bateman a ring "as a signs of imperial approbation". Levell, N. J. (2000), p. 9.

22 Bateman, T. (1817).

23 Ibid., p. v.

24 Levell, N. J. (2000), p. 10.

25 See for example: Gomes, B. A. (1823). Ensaio dermosographico, ou succinta e systematica descripção das doenças cutaneas conforme os principios e observaçôes dos doutores Willan e Bateman, com indicação dos respectivos remedios aconselhados por estos celebres authores e alguns outros. (2nd ed.). Lisboa: Typ. de Academia Real des Sciencias; Calmann, L., \& Bruyn, H. de (1839). Beknopt handboek der huidziekten, volgens het Willan-Batemansche stelsel. Amsterdam: s.n.

26 Willan, R. (1808) quoted in: Haldin-Davis, H. (1931), p. 370.

27 Bateman, T. (1814). A practical synopsis of cutaneous diseases according to the arrangement of Dr. Willan, exhibiting a concise view of the diagnostic symptoms and the method of treatment (Third ed.). London: Longman, Hurst, Rees, Orme, and Brown, p. ix. 


\section{Chapter 2}

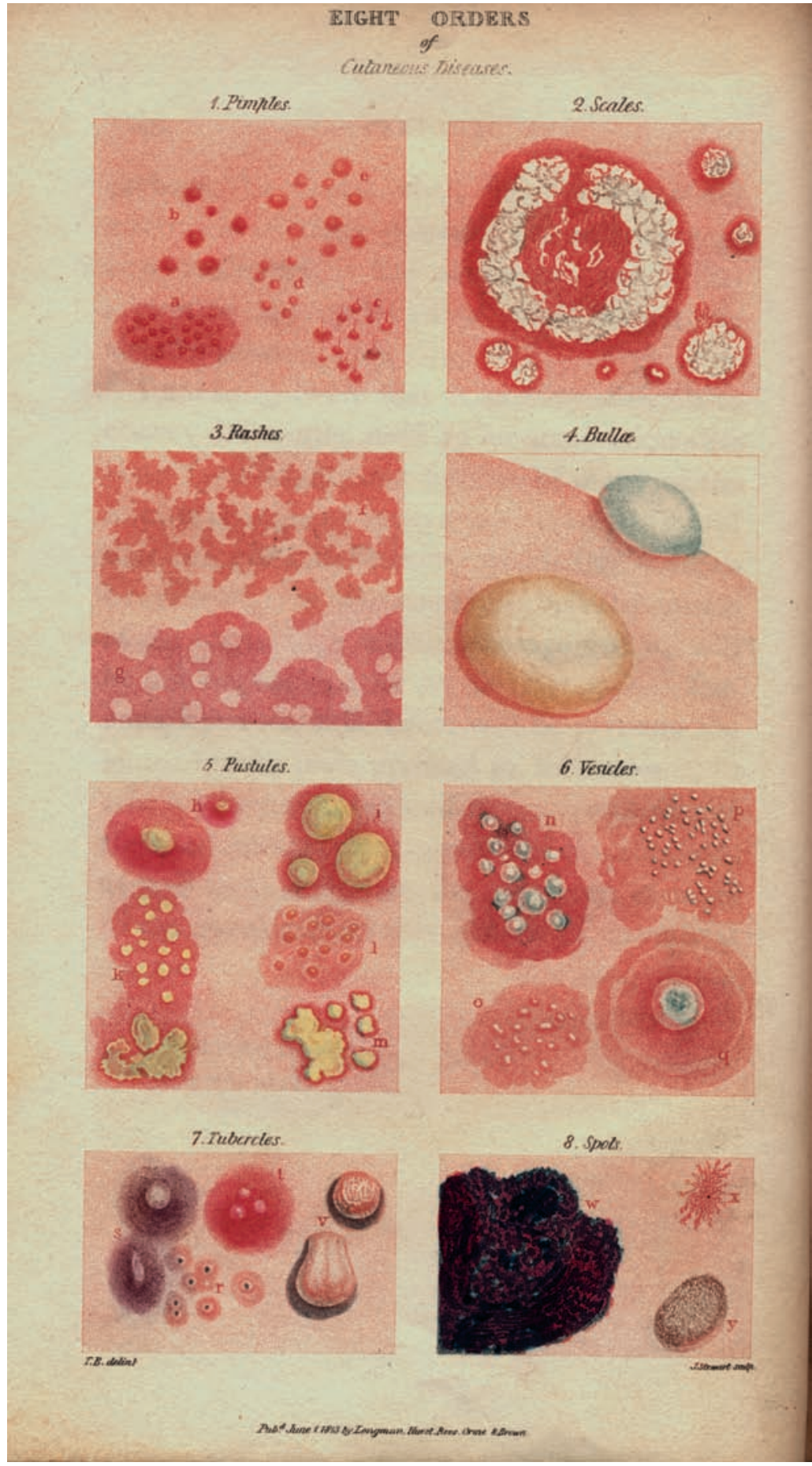

Figure 2.1 'Eight orders of cutaneous diseases.' In Bateman's 1817 A practical synopsis of cutaneous diseases. (8vo). (C) BIUM Paris. 


\section{Surface of recognition}

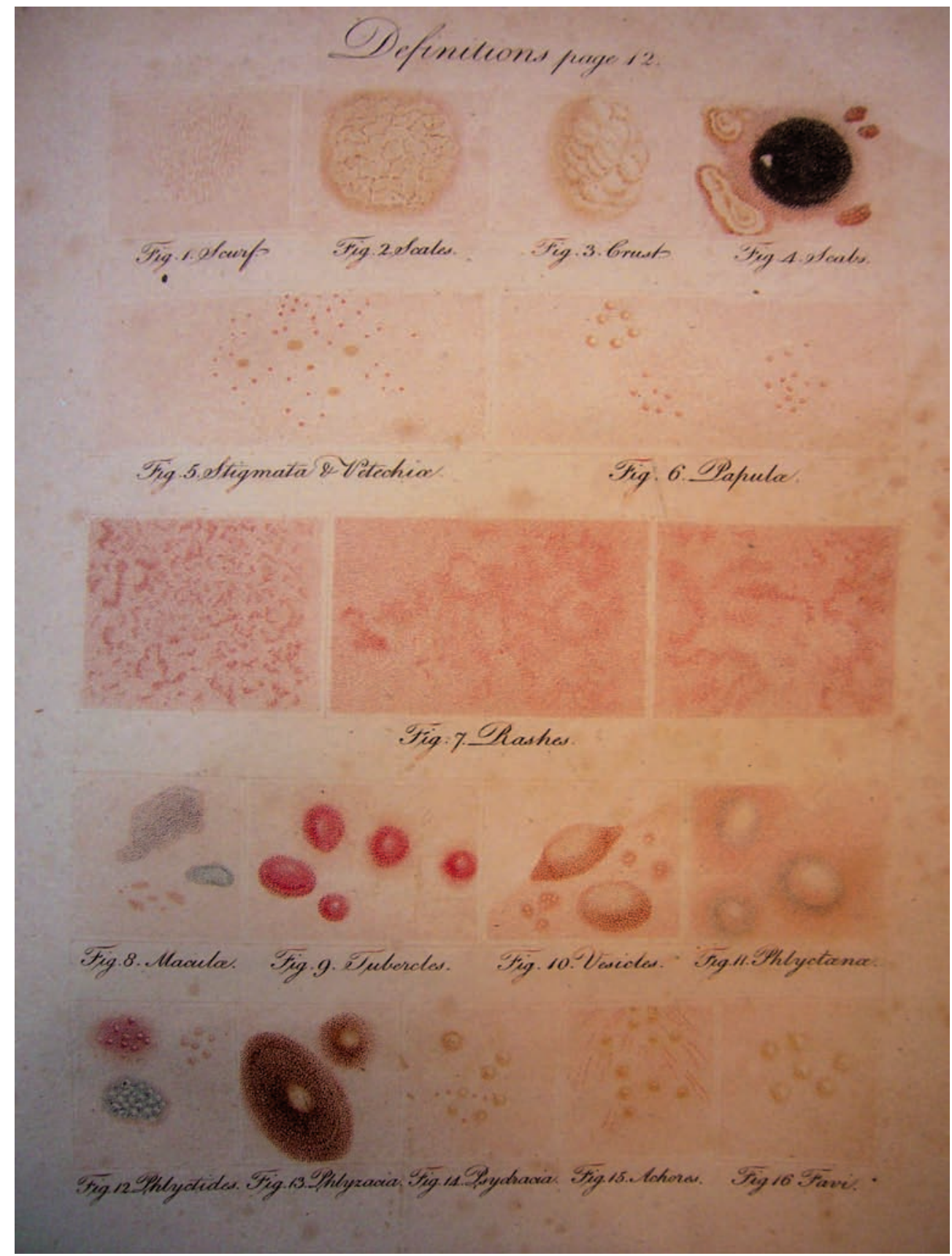

Figure 2.2 'Definitions’ of diseased skin in Robert Willan's 1808 On cutaneous diseases. Vol. I. (4to). 


\title{
Chapter 2
}

forms or varieties", to "class and give names" to the undefined, and to "specify the mode of treatment for each disease". ${ }^{28}$ The outcome was a classification of skin diseases in eight orders, as described by Bateman in his Synopsis: I. Papulae (Pimples), II. Squamae (Scales), III. Exanthemata (Rashes), IV. Bullae (Blebs), V. Pustulae (Pustules), VI. Vesiculae (Vesicles), VII. Tubercula (Tubercles), VIII. Maculae (Spots) (see figure 2.1). ${ }^{29}$ Diseases such as Lepra, Acne, Psoriasis, Scabies, Eczema, Elephantiasis, Smallpox and Birthmarks were now categorised under one of the eight basic orders using the "definitions" of morphological appearance, as Bateman called them after Willan. ${ }^{30}$ Each disease could be reduced to one of the eight "forms of cutaneous eruptions" ${ }^{31}$ According to Bateman, the new arrangement and nomenclature were supposed to:

\begin{abstract}
[L]ead to more clear and definite views on the various forms of cutaneous disease, and should enable practitioners to write and converse respecting them with perspicuity, by fixing the meaning of the terms which they employ, we may consider this as an important object gained: and it will at length, perhaps, be found that, for the successful treatment of these diseases, the discovery of new medicines is less necessary than a discriminate appropriation of those which we already possess. ${ }^{32}$
\end{abstract}

A definite vocabulary of skin diseases would consequently allow for better communication among physicians and could even be of clinical value. Bateman argued that a clear-cut nomenclature carried "manifest advantages", such as the "improvement of observation" and better "discrimination", and it would function as a "means of communication". 33 Identification of skin diseases by their outward appearance and form could lead to a more adequate treatment, because "practical errors" resulting from confusion of terminology would be prevented. ${ }^{34}$ The recognition of the outward form was most important for diagnosis. A common language of skin diseases was supposed to enhance communication, diagnosis and treatment. To recognise was to name, to name was to know, and knowing implied better treatment.

The Willan-Bateman nosology was founded upon textual and visual definitions of eight outward forms of cutaneous eruptions. The visual definitions of skin diseases were important to Willan. His first volume of On cutaneous diseases contained 33 hand-coloured copper engravings. The first plate of 'Definitions' depicted the macromorphological appearance of the various orders of skin diseases (see figure 2.2). The plate consists of five rows, each with two to five sections or squares. The morphological appearance of the particular order was depicted in each square. Each order was represented by one illustration in a square. The illustration represented a most typical form of cutaneous

28 Idem.

29 Initially, Willan arranged the skin diseases into seven orders, combining the bullous and vesicular eruptions in one order, see Beswick, T. (1957), p. 363. As the first volume of Delineations by Willan only contained the description of the first four orders, Bateman finished the classification into eight orders: Bateman, T. (1814), p. xxiv.

30 Bateman, T. (1814), p. xx.

31 Ibid., p. xix.

32 Ibid., pp. xvii-xviii.

33 Ibid., p. viii.

34 Ibid., p. ix. 


\title{
Surface of recognition
}

eruption for one order. A particular disease like roseola (measles) could then exhibit multiple forms, yet the characteristic form belonged to the exanthemata (Order 3). The visual definitions formed the building blocks for the emergent visual language of diseased skin.

Using such a large quantity of illustrations was new for books on skin diseases. Willan emphasised that the inclusion of illustrations in his work was new. ${ }^{35} \mathrm{He}$ argued that the use of illustrations had both advantages and disadvantages:

\begin{abstract}
In order to convey distinct ideas on the subject, I shall elucidate every genus by coloured engravings representing some of its most striking varieties. This method is new, and will be attended with many advantages; though at the same time subject to a variety of imperfections. Such representations cannot sufficiently express the various degrees of opacity and clearness in Pustules; nor the quantity of the matter discharged from superficial ulcerations; neither can they extend to every minute circumstance in the course of the disease, being necessarily taken at some fixed period of it. I would therefore wish the drawings to be considered only as auxiliaries to the verbal descriptions: as such, they will be more especially useful in showing the number, form, size, and colour of the Papulae, Pustules, Tubercles, Spots, etc. constituting the disease, which appearances cannot be clearly communicated in words. ${ }^{36}$
\end{abstract}

Willan described the illustrations as useful visual definitions of the appearance of diseased skin adding to the verbal description. As aids to the textual parts in the book, the illustrations exemplified different kinds of pathologies of the skin surface. The images captured something that was impossible to put into words: the characteristic visual appearance of diseased skin. Indeed, illustrations were important for Willan despite his reservations. On the one hand Willan mentioned illustrations as additional aids to the text. On the other he referred to those aspects of skin diseases that could not be put in words: the "number, size, form and colour" of skin eruptions. Whereas the text described the temporal changes of the eruptions, the illustrations displayed the spatial characteristics of skin diseases. Impossible to express in words, the number, size, form and colour of skin diseases demanded a visual language.

Willan's visual categories of skin diseases were spread by Bateman in his synopsis. The popularity of Bateman's pocketsize work enabled the visual definitions to travel far beyond the boundaries of Britain. In his Practical synopsis of cutaneous diseases Bateman made a strong link between classification and visualisation. The book contains a single plate explaining the external forms of the eight orders of skin disease (see figure 2.1). Similar to the plate by Willan, Bateman's illustration showed the morphological forms of skin diseases. Bateman stressed that the plate was not a mere supplement, but a fundamental part of the classification of skin diseases:

35 See Haldin-Davis, H. (1931), p. 374: “The claim made by Willan that illustrations were a novelty in a book in skin diseases is supported by the fact that after an extensive, (although I will not say an exhaustive), search among medical periodicals produced towards the end of the eighteenth century, I have only been able to find one illustration depicting a skin disease."

Willan, R. (1808), pp. x-xi. 


\section{Chapter 2}

I am fully aware that it is very difficult to convey by words, used in an acceptation that is not familiar, distinct notions of many of the minute changes of appearance in the skin; and that one great deficiency, which Dr. Willan's larger work was calculated to supply, by means of the engravings which accompanied it, will be left unprovided for by this Synopsis. Perhaps, however, this defect will be partially obviated by the plate prefixed to this volume, in which I have endeavoured to convey an idea of the fundamental principles of the classification as well as to designate the characters of some of the more remarkable genera of cutaneous disease. ${ }^{37}$

The plate consisted of eight compartments, exhibiting "the eight forms of cutaneous eruptions, and (...) also some of the genera and species". ${ }^{38}$ The division into eight compartments corresponded to the classification into eight orders, while within each compartment itself multiple forms, stages or variations of skin diseases were illustrated. Illustration number 7 for example demonstrated "different forms of tubercles; as in ( $\mathrm{r}$ ) Acne punctata, and (s) Acne indurate; in (t) Sycosis: and in (v) Molluscum" ${ }^{39}$ A Tubercle was defined in the text as "a small, hard, superficial tumour, circumscribed, and permanent, or suppurating partially". ${ }^{40}$ As in Willan's work, text and image together constituted the classification. The text explained the consistency, feel, proportion and temporal development of a particular skin eruption. It would for example state that a Pimple is a "very small and acuminated elevation of the cuticle (...) commonly terminating in scurf" or that a Scale is "hard, thickened, whitish and opaque". ${ }^{41}$ The visual counterpart showed the appearance in form, colour, size and density. With a single glance at Bateman's plate, physicians from Portugal to America could grasp the new classification of skin diseases.

\section{Skin diseases in early medical traditions}

The Willan-Bateman approach to skin diseases was firmly rooted in the eighteenth century spirit of nosology. To understand the position of the Willan-Bateman classification, we need to place it on a broader palette of earlier traditions and conceptions of skin diseases. According to Bateman, Willan's classification resided in the same principle as a system by the Hungarian physician Josef Plenck (1735-1807). ${ }^{42}$ Among a wide variety of books on diverse subjects in medicine, Plenck had published Doctrina de morbis cutaneis in $1776 .{ }^{43}$ In this small work Plenck proposed a classification of skin diseases into 14 orders. ${ }^{44}$ With

37 Bateman, T. (1814), p. xviii.

38 Ibid., p. xix.

39 Idem.

40 Bateman, T. (1814), pp. xxii-xxiii.

41 Ibid., p. xx.

42 See Bateman, T. (1814), pp. x-xi. Plenck's name is spelled differently in various sources. On Plenck see: Lane, J. E. (1933). Joseph Jacob Plenck 1738?-1807. Archives of Dermatology and Syphilology, 28, 193-214.

43 Plenck, J. J. (1776). Doctrina de morbis cutaneis: Viennae. This book was translated in German, Italian and Dutch. See for a reprint of the Dutch edition: Plenck, J. J. (1980). Leerstuk wegens de huidziekten: waar in deze gebreken onder hunne orden, geslagten en soorten gebragt worden (R. Arends, Trans.). Dordrecht: Nicolaas de Rot en Johannis Crevel Boekverkopers.

44 Bateman noted that "nine of the fourteen classes very nearly correspond with the eight orders of Dr. Willan" and that Willan's definitions and terms "accord accurately with those of the Hungarian nosologist". Bateman, T. (1814), p. xi. 


\section{Surface of recognition}

this classification Plenck strove to "reduce to a system the vast and unclassified mass of these diseases". ${ }^{45}$ He argued that before him authors were used to dividing the diseases of the skin into "sharp" diseases, which are short term and appear with fever, and "longterm" diseases characterised by an absence of fever and a long-term settlement. ${ }^{46}$ Plenck's ambitions to launch a new nosology of skin diseases followed in the line of the "celebrated men" Sauvage, Linnaeus, Vogel and Cullen. ${ }^{47}$ Willan's classification and terminology in part go back to Plenck's system. Yet Plenck's Doctrina did not contain any images, neither did it explicitly stress the morphological basis of skin diseases. What happened before physicians such as Plenck, Willan and Alibert introduced their classifications and illustrations of skin diseases in the early decades of the nineteenth century? How had physicians conceived of diseased skin until then? In this section I explore conceptions of skin diseases preceding early nineteenth century visual definitions of diseased skin.

In the sixteenth century visions of skin diseases followed Galenic humoral theory. ${ }^{48}$ The lectures on skin diseases by the Italian physician Hieronymous Mercurialis (15301606) are exemplary in this respect. ${ }^{49}$ His pupil Aicardius published Mercurialis's lectures on skin diseases in the treatise De morbis cutaneis et omnibus corporis humani excrementis (1572). Following the teachings of Galenic medicine, Mercurialis saw disease as a disturbance in the balance of bodily fluids or humours. In this line of thinking the skin had no "common functions". ${ }^{50}$ However, the skin was involved in several processes, such as the reception of nourishments from the veins which "the skin must of necessity assimilate, unite, and distribute". ${ }^{51}$ Skin diseases would result from reception of waste materials or a disturbance of the humours it contains.

The skin, all physicians apparently agree, has been placed about the bodies of animals as a protective covering for the flesh and members. Hippocrates in his book on bones seems to have said that nature had a further purpose in providing skin. He wrote that it is a binding for the body parts, which, being individually separate, require a common bond, and this is the skin. Thus the divine Plato rightly likened the skin to a fisherman's net, as Galen did also. Since this is the only function of the skin, which has no use save as a receptacle for waste materials, as Galen taught, it is subject to a variety of diseases, all of which I intend to discuss. I shall classify them under two headings: the types of diseases peculiar to the scalp, and those affecting the entire skin. ${ }^{52}$

45 Plenck quoted (translation) in Lane, J. E. (1933), p. 198.

46 Plenck, J. J. (1980), p. 1. My own translation from the Dutch reprinted edition.

47 Lane, J. E. (1933), p. 198.

48 More research is needed on this subject to understand the views towards skin diseases in relation to the work of Vesalius for example. Here, I am only concerned with the work of Mercurialis.

49 Mercurialis, H. (1601). De morbis cutaneis et omnibus corporis humani excrementis tractatus locupletissimi. Venetiis. See also the translation of De morbis cutaneis in: Sutton, R. L. (1986). Sixteenth century physician and his methods: Mercurialis on diseases of the skin. The first book on the subject (1572). Kansas City, Mo.: The Lowell Press.

50 Mercurialis, H. (1601) in Sutton, R. L. (1986), p. 13. Mercurialis followed Galen in the idea that all body parts had two functions, a common one which was useful to all other parts, and an individual function.

51 Idem.

52 Ibid., p. 11. 


\section{Chapter 2}

As the scalp contained the brain, it was very moist and therefore subject to particular defects. The diseases of the entire skin on the other hand were organised into three types: "of colour, of roughness or smoothness, and of bulk". ${ }^{53}$ Mercurialis considered Lepra and scabies as diseases of roughness and smoothness, while moles and other "skin tumours" were diseases of bulk.

Authors of disease systems in the seventeenth century did not pay a great deal of attention to diseases of the skin. The works of the great British clinician Thomas Sydenham (1624-1689) for example deal very little with diseases of the skin. ${ }^{54}$ London physician and anatomist Thomas Willis on the other hand devoted 28 pages to the diseases of the skin in the second volume of his Opera Omnia from 1681.55 Willis distinguished between the outer scarfskin and "the Skin it self". ${ }^{56}$ Since the scarfskin or cuticle was insensible, it had hardly any diseases associated with it. The other diseases of the skin were manifold according to Willis. They differed from each other depending on the appearance of tumours or the presence or absence of fever.

During the seventeenth century the anatomical conception of the skin was framed within a new interest in the small structures of the human body. The Italian anatomist Marcello Malpighi (1628-1694) for example wrote about the anatomical make-up of the skin in his Opera Omnia from 1686. ${ }^{57}$ In his Exercitationes he devoted one part to De externo Tactus Organo. His work is remembered most for the descriptions of a specific sensitive layer of the skin, hairs, hair follicles and excretory glands. ${ }^{58}$ Malpighi's work on the anatomy of the skin did not, however, contain any illustrations. The first illustrative text on the anatomy of the skin in vernacular English appeared in $1698 .{ }^{59}$ The London surgeon William Cowper (1666-1709) claimed that he had 'improved' Govard Bidloo's work and plates. He subsequently discussed the anatomy of the cuticula, the general external surface, hair, fat and the internal "common membrane" ${ }^{60}$ Cowper's descriptions of the skin seemed to follow a hydraulic model of the body. In his text on the layers and structures of the skin Cowper referred to 'vessels', 'ducts' and the transportation of fluids by the skin. ${ }^{61}$ He stated that the skin comprised an anatomy of its own. ${ }^{62}$ The relationship between these important new anatomical investigations and early nineteenth century microscopical conceptions of the skin will be discussed in more detail in chapter 3 .

Surgeons used the new anatomical findings on the skin in early eighteenth century writings on skin diseases. The London surgeon Daniel Turner (1667-1741) published

\footnotetext{
Ibid., p. 12.

See: Thyresson, N. (1986), p. 35.

Idem.

See Willis in Thyresson, N. (1986), p. 36.

57 See for a reprint of the original: Malpighi, M. (1975). Opera Omnia: figuris elegantissimus in aes incisis illustrata. Hildesheim etc.: Olms.

58 See for example: Pusey, W. A. (1979), p. 46.

59 See: Wilson, P. K. (1992). William Cowper's anatomy of human skin. International Journal of Dermatology, 31, 361-363.

60 Ibid., p. 361.

61 Ibid., p. 362. Wilson does not refer to Cowper's hydraulic metaphors for describing the anatomy of the skin.

62 Ibid., p. 363.
} 


\section{Surface of recognition}

one of the earliest elaborated works on skin diseases in $1714 .{ }^{63}$ In his De Morbis Cutaneis (1714) he used Cowper's anatomical and experimental studies of the skin. Turner referred to the skin's ability to transport humours and its function as a passageway for diseases to enter the body. ${ }^{64}$ Before Turner no surgeon had devoted a whole book to skin diseases alone. In contrast to authors writing on skin diseases in general medical works before him, Turner distinguished between diseases with an 'inward' origin and diseases with an 'outward' origin. ${ }^{65}$ Among diseases with an outward origin Turner grouped syphilis, haemorrhoids and bites of venomous "creatures", while lepra, smallpox and spots were of inward origin. ${ }^{66}$ Accordingly, Turner directed his treatments to improve both "the external manifest presentation of the diseases" and the internal cause. ${ }^{67}$ Yet Turner probably did not consider himself as a classifier of skin diseases. ${ }^{68}$ His work was more in line with "eighteenth century compilations of diseases of specific body parts" than with later nosological enterprises concerning all diseases. ${ }^{69}$

During the eighteenth century skin diseases were increasingly classified within gross arrangements of diseases. ${ }^{70}$ Comprehensive nosologies encompassing all human diseases became popular. In particular the taxonomical work of the Swedish naturalist Carl Linnaeus (1707-1778) was very influential in the natural sciences, leading physicians to group diseases into classes, species and varieties as in botany. ${ }^{71}$ The French physician and botanist Boissier de Sauvages (1706-1767) also used a nosology inspired by botanical traditions and the works of Thomas Sydenham in his medical practice and teachings. Based mostly on symptoms, de Sauvages grouped the "superficial affections" (Affectus superficiarii) in his Nosologia methodica (1763). ${ }^{72}$ Among other classes in the first volume of this work, such as fevers, inflammations, painful diseases and convulsive disorders, Boissier de Sauvages denominated the superficial affections as Class I. These encompassed the genera Maculae, Efflorescentiae, Phymata and Excrecentiae. However, Sauvages did not define these diseases as skin affections, but he took the affected external part of the body as the point of departure for this class. Moreover, his arrangement of the genera and species of superficial affections indicates a close relationship of local and general phenomena. For him, the skin was not a basic unit of disease.

Towards the end of the eighteenth century treatises dedicated to skin diseases in

63 Turner, D. (1714). De morbis cutaneis. A treatise of diseases incident to the skin. London: R. Bonwicke. For an outstanding discussion of Daniel Turner's life and work see: Wilson, P. K. (1999). Surgery, skin and syphilis: Daniel Turner's London (1667-1741). Amsterdam: Rodopi.

64 Wilson, P. K. (1999), pp. 66-67.

65 Ibid., p. 64.

66 Idem. See Table 4.1.

67 Idem.

68 Ibid., p. 73.

69 Idem.

70 On the history of nosology of skin diseases in the eighteenth century see also: Tilles, G., \& D. Wallach (1989), pp. 12-16.

71 Bynum, W. F. (1993). Nosology. In W. F. Bynum \& R. Porter (Eds.), Companion encyclopedia of the history of medicine (Vol. 1, pp. 335-356). London: Routledge.

72 Boissier de Sauvages, F. (1763). Nosologia methodica sistens morborum classes, genera et species, juxta Sydenhami mentem et botanicorum ordinem. Amsterdam: Frères De Tournes. On his arrangement of see also: Thyresson, N. (1986), pp. 41-42. 


\section{Chapter 2}

particular appeared. In France professor of medicine Anne-Charles Lorry (1726-1783) published Tractatus de morbis cutaneis in $1777 .{ }^{73}$ Lorry made a distinction between affections that originated in the general interior system of the body (transported to the skin) and affections that originated in the skin itself. ${ }^{74}$ Furthermore, Plenck's work Doctrina de morbis cutaneis from 1776 was also entirely dedicated to the diseases of the skin. ${ }^{75}$ Despite the increasing attention to the skin as a locus of disease, few illustrations of skin diseases accompanied the nosologies. Illustrations were expensive, but used if deemed necessary. The fourth edition of Boissier de Sauvages' Nosologia methodica (1791) already contained some illustrations of affected skin (but not on skin diseases as such) that are important to note. Although the content of the work is very different from Willan's approach to skin diseases, a striking similarity between the two modes of illustration is apparent. Years after de Sauvages' death, the German physician Christian Friedrich Daniel made some additions and illustrations to the Nosologia methodica, including representations of smallpox, scarlet fever, measles and rubella. ${ }^{76}$ Plate XIII contains square compartments numbered 1 to 34 depicting various stages of smallpox (variola). Both the compartmental layout and the focus on the local morphology of the affected skin return in Willan's first plate. Indeed, like de Sauvages and many others, Willan seemed attracted to the application of taxonomical methods and visualisation to classify diseases.

Willan reinforced the eighteenth century idea of a natural history of skin diseases by using illustrations. In his plates Willan made an 'exhibit' of diseased skin, thereby displaying the various skin diseases as natural objects. Likewise, Thomas Bateman explicitly referred to affected skin as an object of natural history in his Synopsis. He even compared the proposed classification of cutaneous diseases to an "arrangement of natural objects" ${ }^{77}$ In the same way as botanists had depicted the various types of forms for leaves, Willan and Bateman depicted the types of morphologies for diseased skin. Their system, including depictions, therefore combined natural history tradition with a new emphasis on skin as a diseased organ, leading to a key classification embodied in pictures.

Willan and Bateman continued in the spirit of the nosological endeavours of the eighteenth century, while also breaking away from past ideas about skin diseases. Theirs was a classification of diseases for a particular organ, focusing on local morphological appearances. Where previous conceptions of affected skin revolved around symptoms and signs of disease in the whole body, Willan concentrated on the observation and diagnosis of the local. A new emphasis on pathological anatomy at the turn of the century shifted physicians' attention to the local lesion. ${ }^{78}$ Willan's work was situated between eighteenth-century system thinking about skin diseases and localist clinical and

76 Daniel, C. F., \& Boissier de Sauvages, F. (1790-1797). Nosologia methodica sistens aegritudines morbos passiones ordine artificiali ac naturali. Castigavit emendavit auxit icones ... adiecet C.F. Daniel. Lipsiae, E. B. Schwickerti. Tome II, plates XI-XV. See also: Ehring, F. (1989), pp. 64-65.

77 Bateman, T. (1817), p. vii.

78 Bynum, W. F. (1994), Science and the practice of medicine in the nineteenth century. Cambridge: Cambridge University Press, p. 45. 


\section{Surface of recognition}

pathological approaches. On the one hand Willan adhered to the older medical principle of 'alternation': "when an eruption appeared, internal disorders would be relieved, and when it disappeared the visceral troubles might start again. (...) If the morbid matter broke out on the skin, its disappearance under treatment might mean either its extinction or its repulsion inward, where it would only start more mischief" ${ }^{79}$ Eruptions on the skin surface were consequently seen as relating to an alternation between bodily outside and inside. Willan also explained the emergence of skin diseases by referring to predisposition, the communication of fevers and spreading of other kinds, and 'unclear causes' ${ }^{80}$ For the last category he reverted to dietary, climatic, physical or mental stimuli as causes of disease.

Yet Willan also partly rejected classical ideas. He fiercely condemned the medical regime of humoralism for example. He considered the humours to be "wholly imaginary" and they should not therefore serve as a guide for treatments. ${ }^{81}$ Extreme blood-letting and purging were dismissed, although on the occasion of a severe or mortal form of disease he would allow for blood-letting. ${ }^{82}$ Moreover, in his attempt to free himself from the older lines of thought, Willan advocated the cultivation of (visual) inspection in diagnosis. To him, the patient's narrative was of less concern than accurate observation. ${ }^{83}$ In this respect his approach (and that of others after him) was clearly related to the new pathological anatomical view on illness exposing the locus of illness and the pathological lesion. The organ-based approach formed an ordering of diseases by bodily location, instead of classifying them under a vast nosological arrangement. ${ }^{84}$ This link between pathology and the diagnosis of skin diseases grew even stronger when French physicians adopted the Willan-Bateman approach after 1816. In the context of the pathological tradition at the Paris hospitals the Willanist method of classifying and diagnosing skin diseases started to compete with other existing views on skin diseases. Inspired by the new approach, physicians and students started to learn and write about skin diseases in similar ways to Willan and Bateman. Indeed, even ways of depicting skin diseases were adopted and adapted as a new language to visually describe and communicate about diseased skin.

\section{Images that matter: more compartments of skin}

Images travel. They travel and provide a means of communication between physicians and across national boundaries. During their travels they are re-evaluated and adapted

79 Findlay, G. H. (1949). The achievement of Robert Willan. British Journal of Dermatology, 61(8-9), 281-286. On p. 283.

80 Ibid., pp. 283-284.

81 Ibid., p. 282.

82 Findlay, G. H. (1949), p. 282.

83 Findlay writes that "History-taking was only of special concern in de diagnosis of syphilis. Otherwise he [Willan] felt that everything could be achieved by overcoming the unwillingness of mankind to observe accurately." Findlay, G. H. (1949), p. 284.

84 See Bynum, W. F. (1994). p. 30-31. 


\section{Chapter 2}

so that new images may emerge as a result. The Willan-Bateman approach and pictures became popular in new contexts following the widespread success of Bateman's Synopsis through Europe. The visualisation of diseased skin as a local morphological alteration gained currency in new territories. Competing with other approaches, Bateman's illustrations underwent revisions and merged with other modes of depiction. This section is devoted to unravelling how this happened and what it meant for the development of a visual language of diseased skin.

In France a 'natural' approach to skin diseases had prevailed until 1816. The view of the famous physician Jean-Louis Alibert (1768-1837), today often praised as the 'founder' of French dermatology, dominated conceptions of skin diseases in Paris. ${ }^{85}$ After the French Revolution Alibert had become physician to l'Hôpital Saint Louis in Paris. He was educated at the École de Santé in Paris, where he became part of the new elite and met Pierre-Jean-Georges Cabanis (1757-1808) and Xavier Bichat (1771-1802). ${ }^{86}$ Cabanis was one of the prime movers of the reorganisation of medical education who stressed the importance of the hospital for teaching, practical research and patient care. ${ }^{87}$ He brought Alibert to the Saint Louis in 1799. Built on the outskirts of Paris in 1607 as a place of isolation for plague patients, the Saint Louis Hospital had always been a place to take care of patients in times of epidemics. In times of no epidemics the hospital 'specialised' in patients with chronic skin problems and ulcerations such as the 'itch', syphilis and scurvy. ${ }^{88}$ When Alibert arrived at the Saint Louis, he became very interested in the study and teaching of skin diseases. In 1807 he was appointed chief medical officer at the Saint Louis. He would become famous for the establishment of the first great teaching centre of skin diseases.

In contrast to the Willan-Bateman approach, Alibert's classification of skin diseases was based on many more criteria besides the local outward appearance of the skin eruption. Even though his classification also resided in observation, he classified skin diseases upon their signs, symptoms, cause, course and duration. ${ }^{89}$ Between 1806 and 1814 he published his observations of skin diseases at the Saint Louis in his Description des maladies de la peau. ${ }^{90}$ His commitment to Hospital Medicine made him a fervent believer in clinical observation. ${ }^{91}$ In 1817 he argued for a 'natural nosology' of all

Alfaric, A. (1917). J. L. Alibert: fondateur de la dermatologie en France: sa vie, son oeuvre, 1768-1837. Paris: J.-B. Baillière; Everett, M. A. (1984). Jean Louis Alibert. The father of French dermatology. International Journal of Dermatology, 23(5), 351-356; Crissey, J. T., Parish, L. C., \& Holubar, K. (2002). Historical atlas of dermatology and dermatologists. Boca Raton etc.: Parthenon Publishing Group, p. 18. Despite its hagiographic overtone, Alfaric's work is useful as a source of historical events in Alibert's lifetime. Alfaric's work is to be preferred over more recent writings on Alibert by dermatologists, since the latter articles are often even more biased towards current dermatological theory and practices.

86 Crissey, J. T., \& Parish, L. C. (1981), p. 41.

87 Bynum, W. F. (1994), p. 29.

88 On Alibert and the Hospital Saint Louis see pp. 32-35 in: Ghesquier, D. (1999). A Gallic affair: The case of the missing itch-mite in French medicine in the early nineteenth century. Medical History, 43, 26-54.

89 Wallach, D. Jean-Louis Alibert (1768-1837) in: Staughton, R. C. D., \& Smith, M. (2000). See also: Tilles, G., \& Wallach, D. (2002), pp. 63-76.

90 Alibert, J. L. M. (1814). Description des maladies de la peau observées à l'Hôpital Saint-Louis. Paris: Barrois, Snr.

91 Jacyna, L. S. (1998), p. 190. For an extensive sociological analysis of the new clinical practice of physical examination in Paris hospital medicine see: Lachmund, J. (1997). Der abgehorchte Körper. Zur historischen Soziologie der medizinischen Untersuchung. Wiesbaden: Westdeutscher Verlag. 


\section{Surface of recognition}

diseases, proposing a philosophical classification that grouped together all diseases with similar 'affinities'. ${ }^{92}$ Like Willan's nosology, this classification was also rooted in eighteenth-century botany and medicine: "Quoique les espèces en nosologie ne puissant être compares aux espèces de la zoologie et de la botanique, on ne peut néanmoins s'empêcher de convenir qu'elles sont toutes fondées sur le rapprochement de certains symptômes qui sont toujours les mêmes". ${ }^{93}$ Alibert's naturalist method called for careful observation of nature and an arrangement of associated characteristics within families. ${ }^{94}$ In his Description this approach resulted in an arrangement of skin diseases into two classes: the diseases of the scalp (teignes) and the diseases of other parts of body (dartres). ${ }^{95}$

For Alibert, as for Willan, illustrations were very important. Even today the 53 hand-coloured copper plate engravings that accompany his Description amaze many physicians by their excellent quality. ${ }^{96}$ In contrast to Willan's small fragments of diseased skin, Alibert's plates displayed skin diseases in highly individualised portraits. ${ }^{97}$ This way of depiction was very much connected with Alibert's approach to skin diseases. As I show later in this chapter, Alibert's convention of the clinical depiction of individualised patients gave rise to another pictorial convention alongside (and later combined with) the Willanist macromorphological imagery. Preceding the rise of another way of depicting skin, however, Alibert's approach came under fierce attack by his own pupils after 1816 . From this point on the Willan-Bateman classification for the diagnosis and treatment of skin diseases became the dominant approach in medical teachings in Alibert's very own hospital clinic.

By 1815 Alibert was renowned in France for his work on skin diseases. The new king Louis XVIII was impressed by Alibert's Description and appointed him as his personal physician. ${ }^{98}$ As he was required to stay and travel with the court at all times, Alibert was no longer able to run his clinic and teach on skin diseases. He therefore turned his clinics at the Saint Louis Hospital over to his pupil Laurent Biett (1781-1840). As the war between England and France had ended in 1813, relations between the countries had been re-established. Thereupon Biett took a patient with him to visit several London hospitals in 1816, where he ended up meeting Bateman at his clinic in the Carey Street Dispensary. Bateman introduced Biett to the Willanist approach to diagnosing and classifying skin diseases. Convinced by the approach, Biett started teaching and spreading the method on his return to Paris. ${ }^{99}$ In the years that followed

Alibert, J. L. M. (1817). Nosologie naturelle, ou les maladies du corps humain distribuées par familles. Paris: Caille \& Ravier. See also: Tilles, G., \& Wallach, D. (1989), p. 18. Besides his works on skin diseases, Alibert published many other works (e.g. on fevers and the physiology of passions).

93 Alibert, J. L. (1817) quoted in Tilles, G., \& Wallach, D. (1989), p. 18. Among others, Alibert was influenced by Sydenham and Pinel.

94 Tilles, G., \& Wallach, D. (2002), p. 68.

95 Wallach, D. (2000), p. 92.

96 See for example: Crissey, J. T. (1951), p. 420; and Stafford, B. M. (1991), p. 300.

97 Benthien, C. (2002), p. 54.

98 Alfaric, A. (1917), p. 81.

99 Ibid., p. 131. 


\section{Chapter 2}

the Willan-Bateman approach came to dominate teachings in the Paris hospitals.

Following Biett, many major Parisian physicians working on skin diseases adopted (and adapted) the Willan-Bateman approach. Historians of dermatology often refer to these followers in the French school as the "French Willanists". ${ }^{100}$ Among them were Biett's pupils Alpheé Cazenave (1795-1877) and Camille Gibert (1797-1866) and the celebrated general physician at the Charité Hospital in Paris Pierre François Olive Rayer (1793-1867). ${ }^{101}$ The Willanist emphasis on the local morphology of skin affections met with a positive response in the French context where principles of localism, tissues and lesions were central in the pathological anatomy of the hospital teaching environment. Important French physicians such as Corvisart (1755-1821) and Laennec (1781-1826) were involved in the shift in Paris hospitals from diagnostic dependence on the symptom to the lesion as central notion. ${ }^{102}$ Accordingly, the 'French Willanists' implemented the Willan-Bateman approach to skin diseases and placed the 'elementary lesion' at the forefront. In their Abrégé pratique des maladies de la peau (1828) Cazenave and Henri Schedel explicitly referred to the classification of skin diseases upon their exterior forms and elementary lesions: "Ainsi, nous avons classé les maladies de la peau (...) d'après leurs formes extérieures, leurs lésions élémentaires". ${ }^{103}$ The Abrégé pratique des maladies de la peau was a compilation of the clinical lectures by Biett, Cazenave's and Schedel's teacher, and was to become a very important means in the spread of the Willan-Bateman classification throughout Europe in the nineteenth century. ${ }^{104}$ The localist approach to skin diseases was now very successful all over Europe.

With the appropriation of the Willan-Bateman approach, the French Willanists also adopted and adapted Willanist ways of depicting skin diseases. This is very striking in an early treatise by the general physician Pierre Rayer. He published a work on skin diseases in 1826, when he was working at the Hôpital Saint-Antoine in Paris. ${ }^{105}$ This Traité théorique et pratique des maladies de la peau comprised two volumes and a separate atlas with ten coloured stipple engraved plates (see figure 2.3). The layout of all the plates shows an exceptional resemblance to the plate in Bateman's Synopsis. Every plate contains four to ten square frames, or compartments, filled with a local macromorphological image of a skin disease and its different types, varieties or stages. Each compartment shows a fragment of affected skin, which may be more or less depicted as a recognisable part of the body. Like Bateman's plate, the copper engravings in Rayer's work focused very much on the local skin lesion. Yet Rayer did not merely copy Bateman's concepts

100 See Tilles, G., \& D. Wallach (1999); Crissey, J. T., Parish, L. C., \& Holubar, K. (2002), pp. $27-38$.

101 Tilles, G., \& Wallach, D. (1999), p. 1124.

102 Bynum (1994), p. 45; Lachmund, J. (1997). See also: Foucault, M. (1963). La naissance de la clinique: une archéologie du régard médical. Paris: Gallimard.

103 Cazenave, P. L. A., \& Schedel, H. É. (1828). Abrégé pratique des maladies de la peau: d'après les auteurs les plus estimés, et surtout d'après des documents puisés dans les leçons cliniques de M. le docteur Biett. Paris: Béchet jeune, p. xiv.

104 The work was translated in English (1842) and Spanish (1851), and went through several editions.

105 Rayer, P. F. O. (1826). Traité théorique et pratique des maladies de la peau, fondé sur de nouvelles recherches d'anatomie et de physiologie pathologiques. Paris: J.-B. Baillière. On Rayer see: Beeson, B. B. (1930). Pierre François Rayer 17931867. Archives of Dermatology and Syphilology, 22, 863-867; and Théodoridès, J. (1995). Pierre François Olive Rayer (1793-1867). Journal of Medical Biography, 3(4), 192-196. 


\section{Surface of recognition}

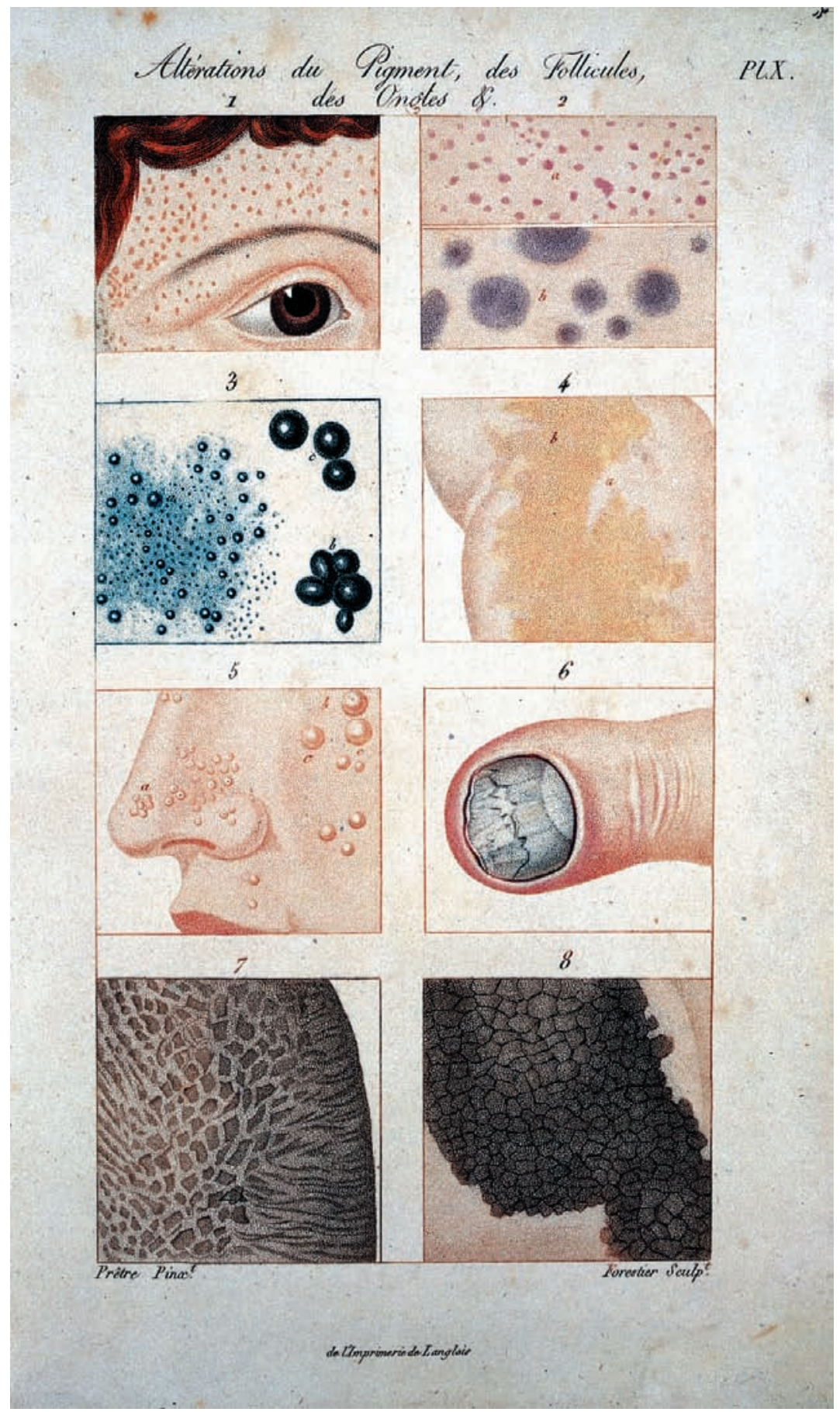

Figure 2.3 'Alterations du pigment, des follicules, des onotes.' In Rayer's 1826 Traité théorique et pratique des maladies de la peau, fondé sur de nouvelles recherches d'anatomie et de physiologie pathologiques. $(21 \mathrm{~cm}, 8 \mathrm{vo})$. Wellcome Library, London. 


\section{Chapter 2}

and depiction. Instead, he tailored the macromorphological style of depiction to his own classification plan for skin diseases. He adopted Willan's nomenclature and adjusted it to his own anatomical and physiological pathological findings. ${ }^{106}$ Rayer intended using the book to communicate his observations and findings on skin diseases to medical students.

Rayer's atlas presents an example of the extension of the localist fragmented way of depicting skin diseases. He used a similar vocabulary to communicate and present his studies in skin diseases to his students and fellow physicians. Many historians of dermatology have overlooked the first edition of Rayer's Traité and have concentrated one-sidedly on the second revised edition from $1835 .{ }^{107}$ Yet the compartmental way of depicting skin diseases in the first edition explicitly reveals the French adaptation of the Willan-Bateman way of depiction. In the introduction to the Traité Rayer defended his way of depiction by comparing it to the works of Willan and Alibert. He complained about the disadvantages of Willan and Alibert's plates:

\footnotetext{
Quelques auteurs ont essayé de rendre les descriptions des maladies de la peau plus frappantes à l'aide de figures coloriées. Les deux plus belles collections en ce genre sont, sans contredit, celles de Willan et Bateman (1) et de M. Alibert (2). Plusieurs de ces planches n'offrent cependant que l'indication d'une des périodes des inflammations qu'elles sont destinées à représenter. Aussi est-il arrivé que telle maladie décrite comme pustuleuse, a été figurée à l'état squameux (...). Les fautes que je viens de signaler ont dû être évitées dans la composition des planches de cet ouvrage. Les formes primitives des inflammations de la peau et les altérations qui leur succèdent y ont été représentées avec soin, d'après nature ou d'après les meilleures gravures qui en ont été publiées. ${ }^{108}$
}

Whereas Willan himself had already admitted the 'drawback' of the static quality of his illustrations, Rayer now chose to pay more attention to the temporal aspect of disease development in his depictions. In his plea for a fragmented composition of his plates, Rayer underlined the significance of visualising different stages of skin affections in one square or piece of skin. In contrast to Alibert in particular Rayer refused to visualise skin diseases in highly individualised portraits of patients. He would rather choose to present different stages of affection within one typified piece of skin:

Des figures de grandeur naturelle, dans lesquelles on aurait représenté la tête, le tronc, les membres ou tout le corps, n'auraient pu faire partie d'un ouvrage élémentaire; elles n'auraient eu, d'ailleurs, que le faible avantage d'offrir la même altération sur un plus grand nombre de points. Cent pustules et vingt tubercules de la couperose, par exemple, épars sur le visage d'une femme dont on a fait dessiner la tête et le buste, avec des ajustements d'un style plus ou moins élégant, ne donnent pas une idée plus nette de la forme pustuleuse de cette affection et des tubercules par lesquels elle se

106 Rayer, P. F. O. (1826), p. vii: "En adoptant la nomenclature de Willan qui m'a paru incontestablement la plus exacte, je n'y ai apporté qu'un petit nombre de modifications indispensables."

107 See for example: Wallach, D., \& Tilles, G. (1991). L'oeuvre dermatologique de Pierre Rayer. Histoire des Sciences Médicales, 25, 278-284; and Crissey, J. T., \& Parish, L. C. (1981), p. 118.

108 Rayer, P. F. O. (1826), p. xxiv. 


\section{Surface of recognition}

termine quelquefois, qu'un lambeau de peau sur lequel ces altérations sont figurées. Enfin, quelques papules du prurigo ou du lichen, quelques plaques squameuses de la lèpre ou du psoriasis, etc., suffissent pour faire connaître le caractère de ces maladies, sans qu'il soit nécessaire de représenter toutes les régions du corps sur lesquelles ces formes phlegmasiques ont été observées. ${ }^{109}$

Here Rayer clearly expressed the close relationship between the communication of elementary knowledge about skin diseases and his way of depiction. The fragmented, macromorphological way of depicting skin diseases consequently reinforced the focus on the elementary lesions. In this pictorial convention the diseased skin became a readable surface, much like a storyboard that unfolds the scenes of developing skin diseases.

It was not only French physicians such as Rayer who adapted the compartmental depiction of skin diseases. Closer to home British physicians also embraced and revised a compartmental way of depicting skin diseases. The London physician Anthony Todd Thomson (1778-1849) had worked with Willan. He published his Atlas of delineations of cutaneous eruptions in $1829 .{ }^{110}$ The work contained 12 coloured plates with copper engravings. Each plate contained three to seven squares of affected skin, very much like Rayer's first edition of the Traité. However, Thomson's intentions with the atlas were explicitly educational. He wanted to "place in the hands of the Student a cheap substitute for the valuable but expensive Delineations of Dr. Bateman". ${ }^{111}$ Most of the illustrations in the atlas were indeed reduced fragments derived from the plates in the Delineations by Bateman. The educational value of the atlas was increased by the depiction of several stages of each skin affection within one illustration:

The Editor has endeavoured to render them [the reduced representations] more useful to the Student than plates usually are, by marking on the Plate the commencement, progress, and terminations of each eruption, as far as this can be accomplished in a single representation. (...) The advantage of teaching by the eye, as an aid to verbal description, in communicating a knowledge of the diseases which these Plates are intended to represent, is so obvious, that the Editor hopes these delineations will be regarded as important additions to the Synopsis; whilst, at the same time, the separate publication of the Atlas places it in the power of any one either to purchase it with the present Editions of the Synopsis, or, if he be satisfied with the former Editions, to purchase the Atlas independent of the Synopsis. ${ }^{112}$

Thomson here referred to the seventh edition of Bateman's Synopsis, which he edited himself. ${ }^{113}$ In this way Thomson extended the macromorphological way of depicting

109 Ibid., pp. xxiv-xxv.

110 Thomson, A. T. (1829). Atlas of delineations of cutaneous eruptions; illustrative of the descriptions in the Practical synopsis of cutaneous diseases of Thomas Bateman. London: Longman, Rees, Orme, Brown, and Green.

111 Ibid., Advertisement.

112 Idem.

113 See for example: Bateman, T., \& Thomson, A. T. (1829). A practical synopsis of cutaneous diseases according to the arrangement of Dr. Willan, exhibiting a concise view of the diagnostic symptoms and the method of treatment (7th ed.). London: Printed for Longman, Rees, Orme, Brown \& Green. Thomson also edited the $8^{\text {th }}$ edition of the Synopsis (1836). 


\section{Chapter 2}

skin diseases with illustrations as teaching aids.

Rayer and Thomson's continuations of the localist, fragmented and compartmental way of depicting skin diseases demonstrate the onset of a visual language of diseased skin. We should regard both works as transformations and appropriations of Bateman's work and classification. Both ways of depiction are visually comparable and functioned in educational settings. Whereas Rayer's compartmental depiction stressed the elementary lesions as an analytical basis for skin diseases, Thomson's coloured fragments of affected skin were designed as practical visual teaching aids for the student. ${ }^{114}$ In fact, Thomson himself took steps to convince the reader that his work was original in comparison to Rayer's Traité:

The Author conceives that it is but justice to himself to say, that the plan of this Atlas was sketched out, and many of the Plates executed, before the work of Rayer, "Traité Théorique et Pratique des Maladies de la Peau," was published. He mentions this circumstance to secure himself from the charge of having borrowed the

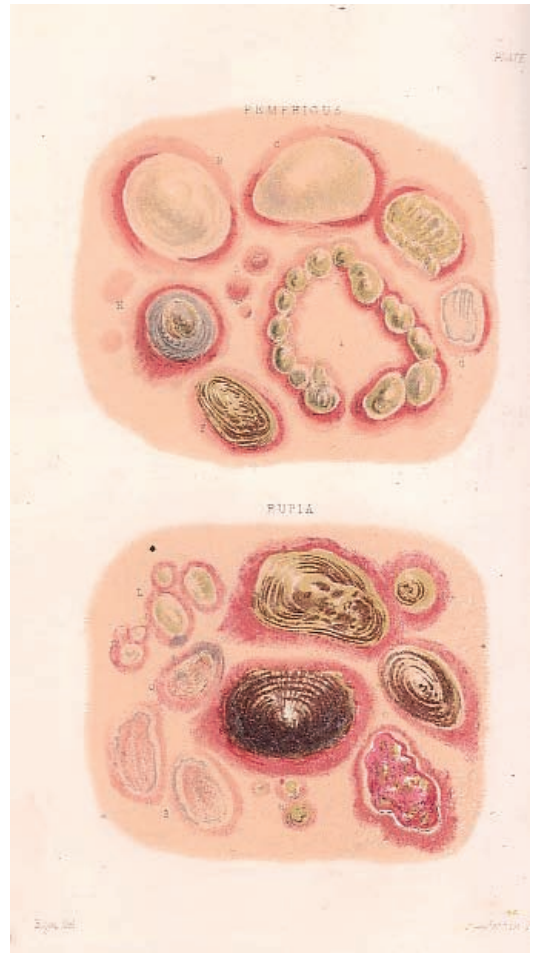

Figure 2.4 'Bullous and rupious eruptions.' In Wilson's On diseases of the skin (1863). $(24 \mathrm{~cm})$ idea of this mode of illustration from his continental contemporary. He has anticipated in the publication of his design: but flatters himself that in no other respect can the French work be regarded as having the advantage of his Atlas. There is a want of fidelity in the representations, and carelessness in the tinting of the French work, which he trusts cannot be charged against the Atlas. ${ }^{115}$

Thomson obviously downplayed the work by Rayer to promote his own atlas. In so doing he shows how similar the way of depiction in the two works is.

In the course of the nineteenth century many different variations and translations of the macromorphological way of depicting skin diseases in small fragments of skin appeared. The abstracted, anonymous piece of skin showing a typical image of the configurations of herpes, eczema or lepra remained an important pictorial convention in the visual language of communicating knowledge on skin diseases (see example in figure 2.4). Yet alongside the highly typified, fragmented and localist depiction of skin diseases, another manner of depicting skin diseases emerged in the early nineteenth century. The French

114 Hand-written and hand-painted copies of Thomson's work exist in notebooks at the Wellcome Institute for the History of Medicine (Archive and Manuscripts material on Thomas Bateman, record number MS1092/1093). One of the authors was possibly a student.

115 Thomson, A. T. (1829), Advertisement. 


\section{Surface of recognition}

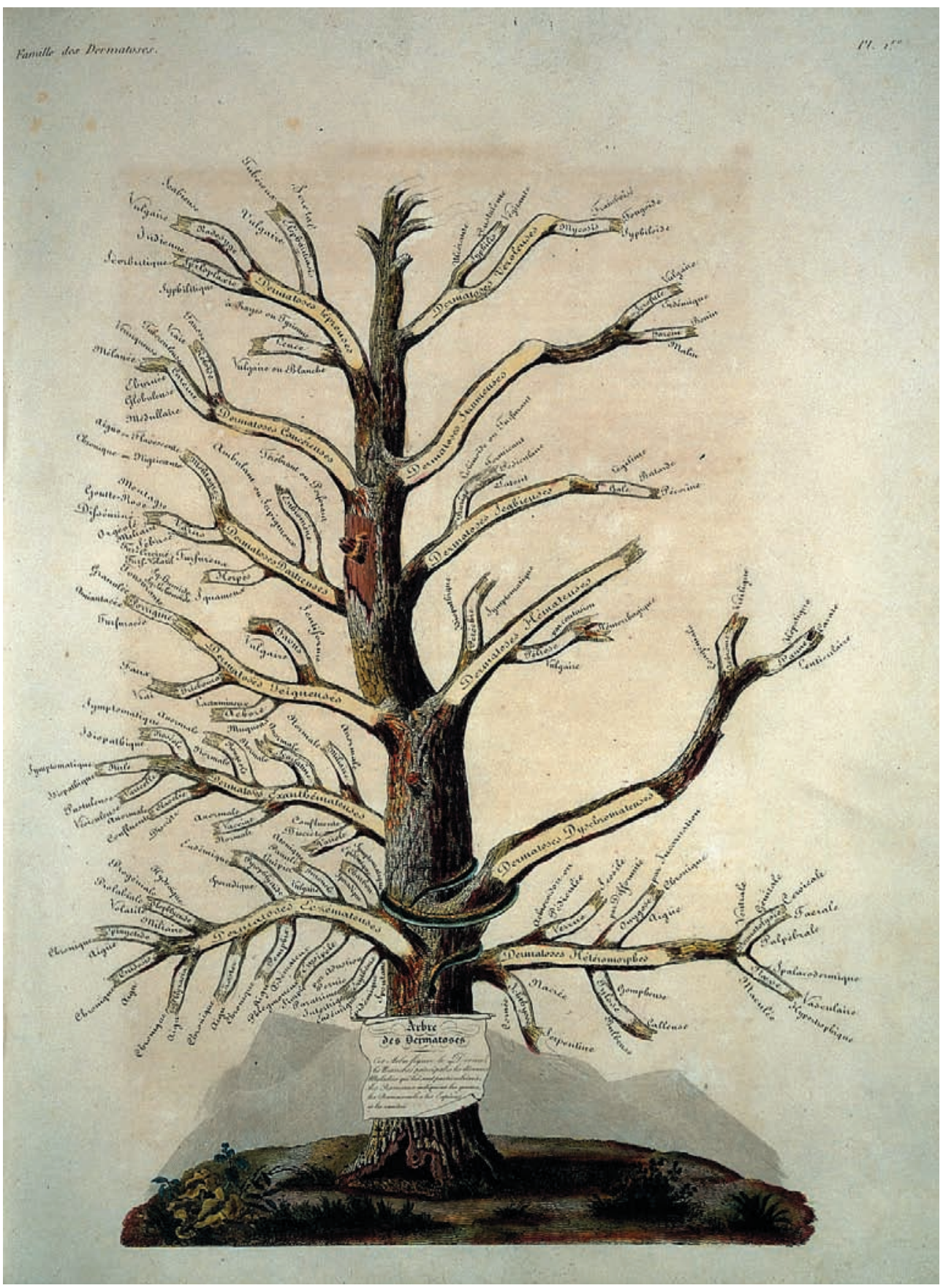

Figure 2.5 Alibert's 'Arbre des Dermatoses'. In his 1833 Clinique de l'hôpital Saint-Louis ou traité complet des maladies de la peau. Wellcome Library, London. 
physician Alibert had already introduced his portrait-like illustrations of skin diseases in his publication of 1806. In the years of his absence from the Saint Louis Hospital the WillanBateman approach and pictorial convention had taken over. On his return to his clinics in 1827, once his royal duties at the court had ended, Alibert would find an unpleasant surprise.

\section{The return of Alibert: clinical depiction}

When Alibert came back to the study of skin diseases at the Saint Louis Hospital in 1827, the Willan-Bateman approach ruled in his former clinics. Alibert was very disappointed to find that his own pupils, whom he had trusted to continue his legacy, had adopted foreign Willanist ideas. ${ }^{116}$ This made him even more determined to fiercely defend and extend his own understanding of skin diseases. With the help of a group of selected scholars, he retreated from the hospital and for two years worked on his new grand project on skin diseases. ${ }^{117} \mathrm{He}$ intended to make a big comeback with a work that would blow the minds of his audience. In 1829 his time had come.

Under the watchful eye of a large audience, Jean-Louis Alibert revealed his new revised and improved classification of skin diseases on April 29, 1829. Physicians and students were captivated by Alibert's passionate oration. A burst of applause sounded when Alibert presented two paintings of his now famous "Arbre des Dermatoses" at the end of his animated speech (see figure 2.5). ${ }^{118}$ The tree symbolised a classification of families of skin diseases that was intended to override the Willan-Bateman approach by its brilliance. Based on numerous observations, Alibert introduced a philosophical classification of skin diseases that accounted for the clinical observations, the cause of the skin disease, treatments and the relationships between the 12 families of diseases. ${ }^{119}$ The tree symbolised his complex classification. The sign on the image of the tree read: "Arbre des Dermatoses. Cet arbre figure le derme, les branches principales des diverses maladies qui lui sont particulières, les rameaux indiquent les genres, les ramuscules les espèces et les variétés". ${ }^{20}$ As indicated above, Alibert understood skin diseases as aggregations of symptoms, cause, duration and appearance. Where for the Willanists skin diseases were individual separate entities, Alibert considered them as closely 'related'. He indicated how the skin diseases "se touchent par différents points et sont plutôt dispersées entre elles comme les feuilles des arbres". ${ }^{121}$ Here, in the garden of l'Hôpital Saint Louis, the conflict between two approaches to skin diseases reached a climax.

116 Crissey, J. T. \& Parish, L. C. (1981), p. 47.

117 Alfaric, A. (1917), pp. 136-137.

118 Ibid., p. 139.

119 Dermatoses eczémateuses, exanthémateuses, teigneuses, dartreuses, cancéreuses, lépreuses, véroleuses, strumeuses, scabieuses, hémateuses, dyschromateuses, and hétéromorphes. See: Alibert, J. L. M. (1832). Monographie des dermatoses, ou, précis théorique et pratique des maladies de la peau. Paris: Chez le Docteur Daynac; Alibert, J. L. M. (1833). Clinique de l'hôpital Saint-Louis ou traité complet des maladies de la peau. Paris: Cormon et Blanc.

120 Tilles, G. (1989). La naissance de la dermatologie (1776-1880). Paris: Roger Dacosta, p. 39.

121 Alibert, J. L. M. (1832) quoted in Wallach, D. \& Tilles, G. (2002), p. 69. 


\section{Surface of recognition}

The story goes that only a few days later Alibert's triumph was swept away by his pupil and adversary Biett, who regained the public for the Willan-Bateman approach. In his lesson Biett carefully and systematically cut down each branch of Alibert's tree and firmly installed the Willan-Bateman approach as the most scientific, clear and simple method for understanding skin diseases: "Le désir seul d'être utile à la science m’a inspiré; j’ai cru trouver plus de clarté, de facilité, de naturel dans la méthode de Willan, je l'ai suivie. Nulle puissance au monde ne peut arrêter les recherches de l'homme". ${ }^{122}$ In the years that followed Alibert became the subject of ridicule and attacks by Willanist followers at the Saint Louis. ${ }^{123}$ His 'tree of dermatoses' in particular became a favourite theme for mockery. In 1833 Biett's students Cazenave and Schedel wrote "l'arbre de dermatoses est déjà mort". ${ }^{124}$ Alibert's "romantisme cutané"125 had lost its flair and was eclipsed by the Willan-Bateman doctrine.

Yet the story of Alibert does not end here. Even though Alibert's fire died, his legacy became manifest in his imagery of skin diseases. He published two illustrated clinical works about skin diseases in 1832 and $1833 .{ }^{126}$ His publications, including earlier works, introduced an important second pictorial building block for a visual language of diseased skin in the 1830s. Alibert was the first to systematically depict skin diseases in the clinical case of the individualised patient. With his manifold illustrations of hospitalised patients with skin diseases, Alibert initiated a clinical 'naturalistic' way of portraying skin diseases as part of an aggregated view of the patient, his disease, his story, signs and clinical observation all together. Accordingly, Alibert depicted all the details of the person with the disease in his illustrations. He introduced the 'clinical' convention in the visual communication and presentation of skin diseases.

Alibert's way of depicting skin disease was connected with emerging attention to the 'clinical picture' in hospital medicine. With his new classification of skin diseases symbolised by his 'tree', Alibert responded to Willanist tendencies to reduce skin diseases to local lesions. Willan had only seen very few patients in his dispensary, leading to a classification that did not account for complex issues of skin diseases Alibert argued. Alibert's desire was to investigate skin diseases by collecting and classifying as many individual cases and phenomena as possible:

J'esquisse l'histoire d'une famille de maladies qui sont devenues très-fréquentes dans le siècle où nous vivons; je trace le tableau d'un grand nombre de phénomènes morbides qui manifestent dans tous les ages, dans tous les rangs, dans toutes les conditions du monde civilisé ; j’ai tenté beaucoup d'effort pour appliquer la méthode des naturalistes au classement de ces phénomènes; je me suis attaché à décrire l'hôpital Saint-Louis, comme les botanistes décrivent un pays ou un jardin. ${ }^{127}$

122 Biett (1829) quoted in Alfaric, A. (1917), p. 141.

123 Alfaric, A. (1917), pp. 144-149.

124 Cazenave, P. L. A., \& Schedel, H. É. (1833). Abrégé pratique des maladies de la peau, d'après les auteurs les plus estimés et surtout d'après les documents puisés dans les leçons cliniques de M. le docteur Biett (2e ed.). Paris, p. 18. Quoted in Wallach, D. and G. Tilles (2002), p. 70.

125 Alfaric, A. (1917), p. 149.

126 Alibert, J. L. M. (1832); Alibert, J. L. M. (1833).

127 Alibert, J. L. (1833), p. 1. 


\title{
Chapter 2
}

For Alibert the individual case of the patient was always the point of departure. Even his way of selecting patients for his illustrations in his books and his lectures demonstrate his clinical gaze in the hospital context:

\author{
Un jour se présenta un pauvre diable affecté d'éléphantiasis bien dessiné, bien caractérisé: \\ C'est superbe, s'écria Alibert. \\ 'M. le Dr, ça peut-il se guérir?' \\ 'Je vous ferai peindre.' \\ 'Mais, monsieur, puis-je espérer d'en guérir ?' \\ 'Certainement, certainement ; mais je vous ferai peindre.' \\ 'Pourrai-je avoir lit dans votre service?' \\ 'Il vous en faudrait dix que vous les auriez'." 128
}

Alibert's illustrations were important as clinical records. Many of the plates in his books are in large portfolio size and contain beautifully detailed engravings of cases (see figure 2.6). ${ }^{129}$ In his Synopsis Thomas Bateman had already condemned Alibert's Description (1814) by claiming that "the merit of his publication belongs principally to the artists, whom he has had the good fortune to employ". ${ }^{130}$ According to Alibert himself, however, the illustrations served a very clear goal. They were part of his clinical doctrine to study the diseases of the skin in the individual case of the patient:
J'ai voulu enfin par les couleurs effrayantes du peintre, instruire pour ainsi dire par la vue, faire ressortir et constater davantage le caractère des maladies de la peau, fixer leurs moindres nuances, frapper en un mot les sens de mes lecteurs et reproduire vivants devant eux les divers phénomènes qui avaient étonné mes regards. ${ }^{131}$

In his illustrations Alibert intended to reproduce the characteristic case of the patient in all its striking aspects. The patient should present himself to the reader in a similar way as Alibert had observed him in the clinic. At the Saint Louis he was able to make many observations of skin eruptions in order to learn about their varieties:

As I worked in an operating theatre where these diseases were constantly being treated, I was the best person to throw some light on the confusion which had characterized previous work. I was able to monitor the progress, the phases, the decline, the resurgences and the evolution of different exanthemata. It was in the hospitals that the different characteristics were most evident because we were able to follow them through all the stages of their development. ${ }^{132}$

128 Poumes de la Siboutie (1910) quoted in Alfaric, A. (1917), p. 54.

129 For elaborated descriptions of Alibert's pictorial works see: Ehring, F. (1989), pp. 104-107.

130 Bateman, T. (1817), pp. xii-xiii.

131 Alibert (1806) quoted in: Alfaric, A. (1917), pp. 76-77.

132 Alibert, J. L. (1825). Description des maladies de la peau, observées à l'Hôpital Saint-Louis, et exposition des meilleures méthodes suivies pour leur traitement (2 ed.). Bruxelles: Auguste Wahlen, discours préliminaire, p. i, quoted and translated in: Ghesquier, D. (1999), p. 33. 


\section{Surface of recognition}

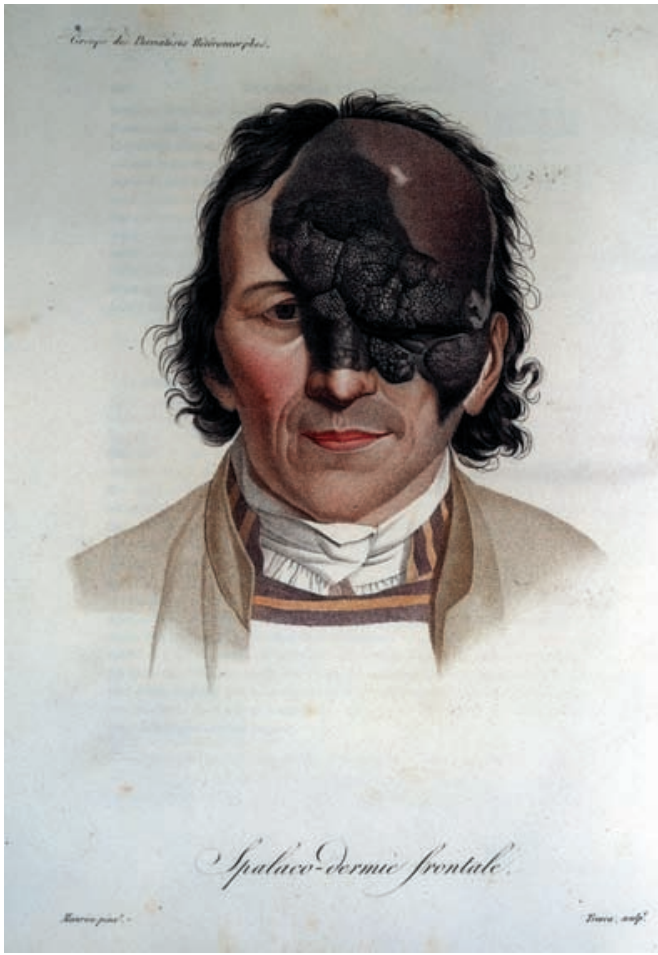

Figure 2.6 Portrait-like illustration 'Spalaco-dermie frontale.' In Alibert's Monographie des dermatoses, ou, précis théorique et pratique des maladies de la peau (1832) (fol.). Wellcome Library, London.

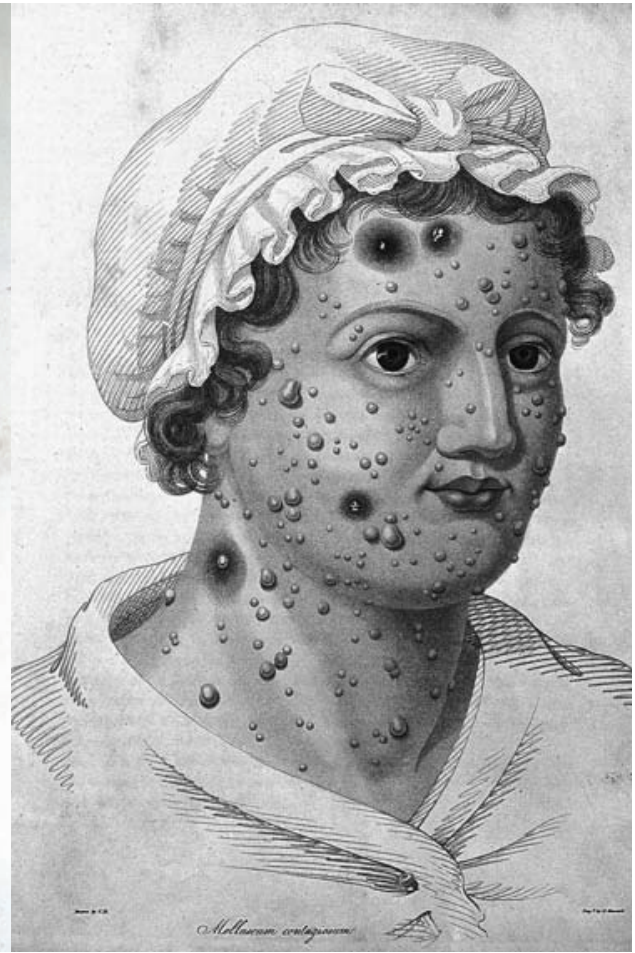

Figure 2.7 Bateman's puppet-like figure 'Molluscum contagiosum.' In Delineations of cutaneous diseases: exhibiting the characteristic appearances of the principal genera and species comprised in the classification of the late Dr. Willan; and completing the series of engravings begun by that author (1817) (4to). Wellcome Library, London.

Medical historian Jacyna discussed Alibert's empiricism and focus on clinical observation in his analysis of Alibert's pictures. ${ }^{133}$ Alibert's work exemplifies the rhetoric of Paris Medicine with its emphasis on clinical observation and examination instead of armchair speculation. For Jacyna Alibert's illustrations even figure in an understanding of the hospital as a theatre. Next to their educational clinical purposes, the illustrations served as "spectacular devices" to impress the reader. ${ }^{134}$

The clinical pictorial style of Alibert's images had a different focus from the macromorphological convention. In the macromorphological way of depiction the characteristic visual form of the lesion was the focal point. Alibert's images, however, show the clinical case as point of departure. Like the written narratives of the patients in Alibert's work, the images showed a high level of detail of the individual. Alibert's 


\section{Chapter 2}

engravings are remarkable for their detailed presentation of the gross skin deformity, the patient's facial features, their distinctive personal temper, posture and clothing. Where the few patients depicted in Willan and Bateman's illustrations give hardly any clues as to their state of mind, the patients depicted by Alibert's artists were described as sitters for a clinical portrait (see figure 2.7 for comparison). As Jacyna has shown, Alibert's way of depiction indeed corresponds to his extensive textual attention to the patient's narrative and his own medical beliefs in the interaction between internal character and outward appearance: "Alibert insisted upon the validity of the physiognomic axiom that the outer envelope faithfully represented the individual's inner essence. The transformations of the body in diseases served only to emphasize this correspondence". ${ }^{135}$ Other authors have also pointed to the relationship between Alibert's iconography and his understanding of skin diseases: "The Illustrations [sic] of skin diseases in Alibert's atlases always included the entire person with physiognomy and clothes, and not only a part of the skin with a lesion. This is the iconographic counterpart of Alibert's 'natural' method." 136

\section{A visual language of skin diseases}

Both the attention to the local lesion and the clinical case return in pictures of skin diseases in the course of the nineteenth century. Important physicians in hospitals all over Europe used a mixture of both ways of depiction in their works. The famous Austrian clinician Ferdinand von Hebra (1806-1880), for example, published his successful Atlas der Hautkrankheiten (1856-1876) containing 104 plates of patients. ${ }^{137}$ Hebra used both the focus on the local typical lesion as well as a detailed picture of the entire patient in his atlas and teachings:

The purpose we have in view in publishing this work consists of our wish to portray as best we can a clinic for patients suffering from skin diseases. With this aim in our mind, the illustrations are intended to replace the patients as the subject matter of our lectures, whilst the text is meant to take the place of the lecturer's words. ${ }^{138}$

Many of the coloured lithographs in Hebra's atlas are very much portrait-like images of patients with a skin disease. However, since Hebra wanted to be able to show the particular pathological lesion within the individual case of the patient, he used a thin outline overlay in each picture "on which the lesions are depicted in outline and numbered". ${ }^{139}$ He consequently found a way of combining the clinical and the morphological traditions

135 Ibid., p. 197.

136 Staughton, R. C. D., \& Smith, M. (2000), p. 91.

137 Hebra, F., Elfinger, A., \& Heitzmann, C. (1856-1876). Atlas der Hautkrankheiten / Text von Ferdinand Hebra; Bilder von Anton Elfinger und Carl Heitzmann; herausgegeben durch die Kaiserliche Akademie der Wissenschaften. Wien: Druck der Kaiserlich-Königlichen Hof- und Staatsdruckerei in Commission bei C. Gerold's Sohn.

138 Hebra quoted in Ehring, F. (1989), pp. 160-161.

139 Ehring, F. (1989), p. 161. 


\section{Surface of recognition}

of depicting skin diseases. Both the typical lesion and the individual case of the patient were visually intertwined in his work.

The amalgamation of the clinical and morphological styles was already visible in the 1830s. When new aetiological and other classifications of skin diseases emerged, the initial distinction between the two pictorial conventions became diffuse. From the 1830 s onwards physicians deployed a visual language of skin diseases that combined the clinical with the local to present knowledge and communicate with each other. While the study and treatment of skin diseases emerged as a specialisation in the middle of the nineteenth century, pictorial conventions were consolidated. The morphological and clinical pictorial styles remained dominant conventions during the nineteenth century, although never in a 'pure' form. Both ways of depiction formed the starting points for a pictorial tradition continuing with modes of depicting skin diseases in the nineteenth century.

The merger of morphological and clinical depictions went hand in hand with new approaches to skin diseases. Pierre Rayer's second, completely revised edition of his Traité théorique et pratique des maladies de la peau from 1835 shows the introduction of pathological anatomical findings in the study of skin diseases. ${ }^{140}$ Rayer combined 'Alibert-like' empirical clinical observations in many hospitals ${ }^{141}$ with changes in the Willanist elementary forms of skin eruptions:

Le meilleur moyen d'acquérir ces connaissances est d'observer un grand nombre de faits individuels, de s'attacher à démêler les formes élémentaires des éruptions, leurs transformations et leurs dégradations successives. ${ }^{142}$

The illustrations in the atlas of the Traité were part of Rayer's combined approach. With a staggering 400 figures in 21 engraved coloured plates the atlas is impressive. In his preface to the atlas Rayer explained how he combined the illustration of individual observed cases with characteristic images of skin lesions in fragments to cater for both the medical practitioner and the student:

L'utilité d'un Atlas qui réunirait dans un même cadre la généralité des maladies de la peau, et dans lequel elles seraient représentées fidèlement, avec leurs diverses apparences, et groupées dans un ordre systématique, ne peut donc être contestée; car une pareille collection, pour atteindre pleinement le but, doit rappeler au praticien ce qu'il a vu, aider l'étudiant à acquérir l'art du diagnostic, et suppléer jusqu'a un certain point, pour l'un et pour l'autre, à l'absence même des malades. ${ }^{143}$

140 Rayer, P. F. O. (1835). Traité théorique et pratique des maladies de la peau, avec un atlas in quarto (2me ed., entièrement ref.). Paris: J.B. Baillière.

141 In his Préface to the atlas of the Traité (1835), Rayer mentions many places in Paris where he observed patients with skin diseases: l'Hôpital Saint-Louis, l'Hôpital la Pitié, le Bureau Central des Hôpitaux, and l'Hospice de Vénériens. Rayer, P. F. O. (1835), p. 9.

142 Rayer, P. F. O. (1835), p. 10.

143 Ibid. 


\section{Chapter 2}

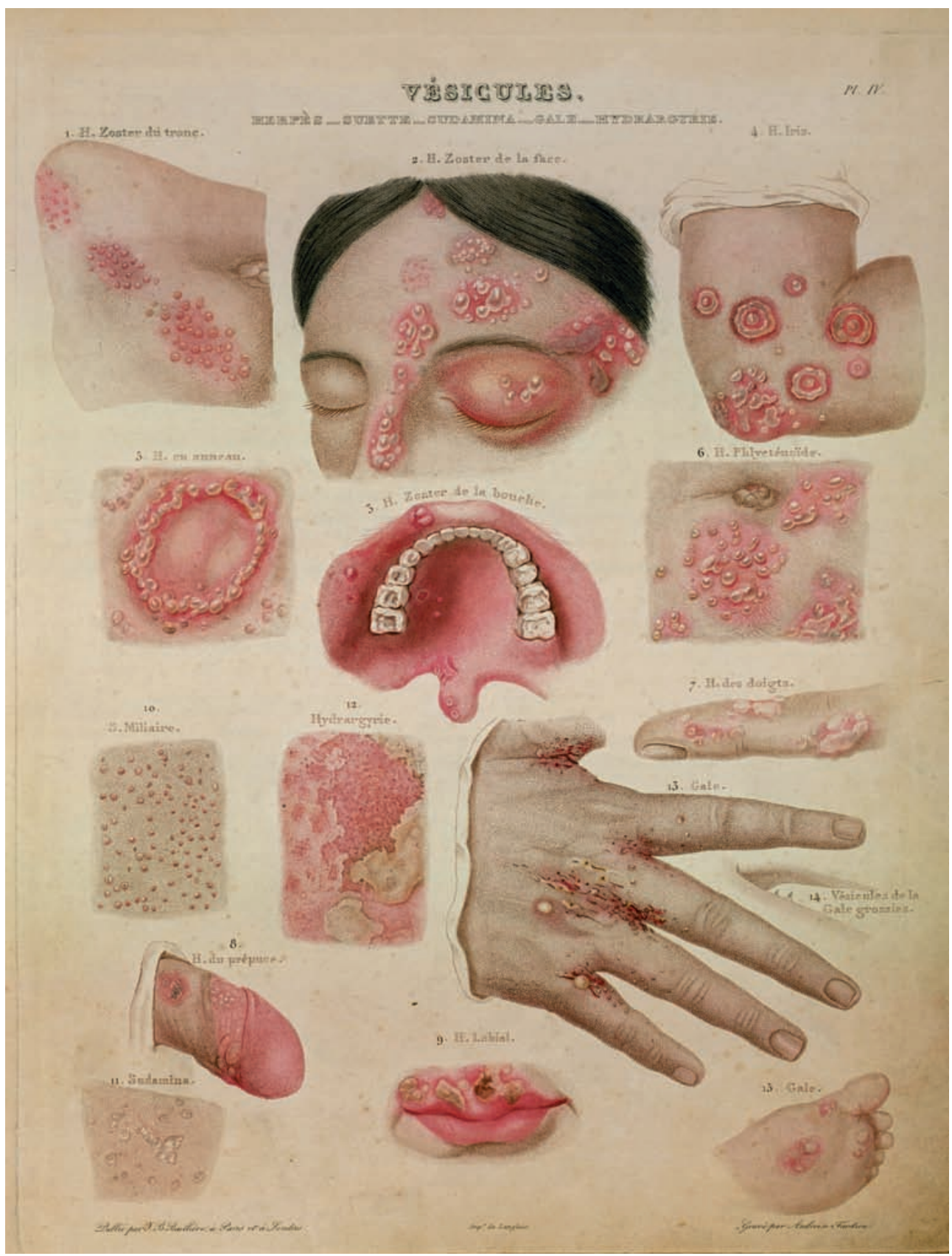

Figure 2.8 Plate 4 in Rayer's 1835 atlas with the second revised edition of Traité théorique et pratique des maladies de la peau: atlas (8vo). 'Vésicules. Herpès, suette, sudamina, gale, hydrargyrie.'

(C) BIUM Paris.

http://www.bium.univ-paris5.fr/histmed/medica/page?00584\&p=22 


\section{Surface of recognition}

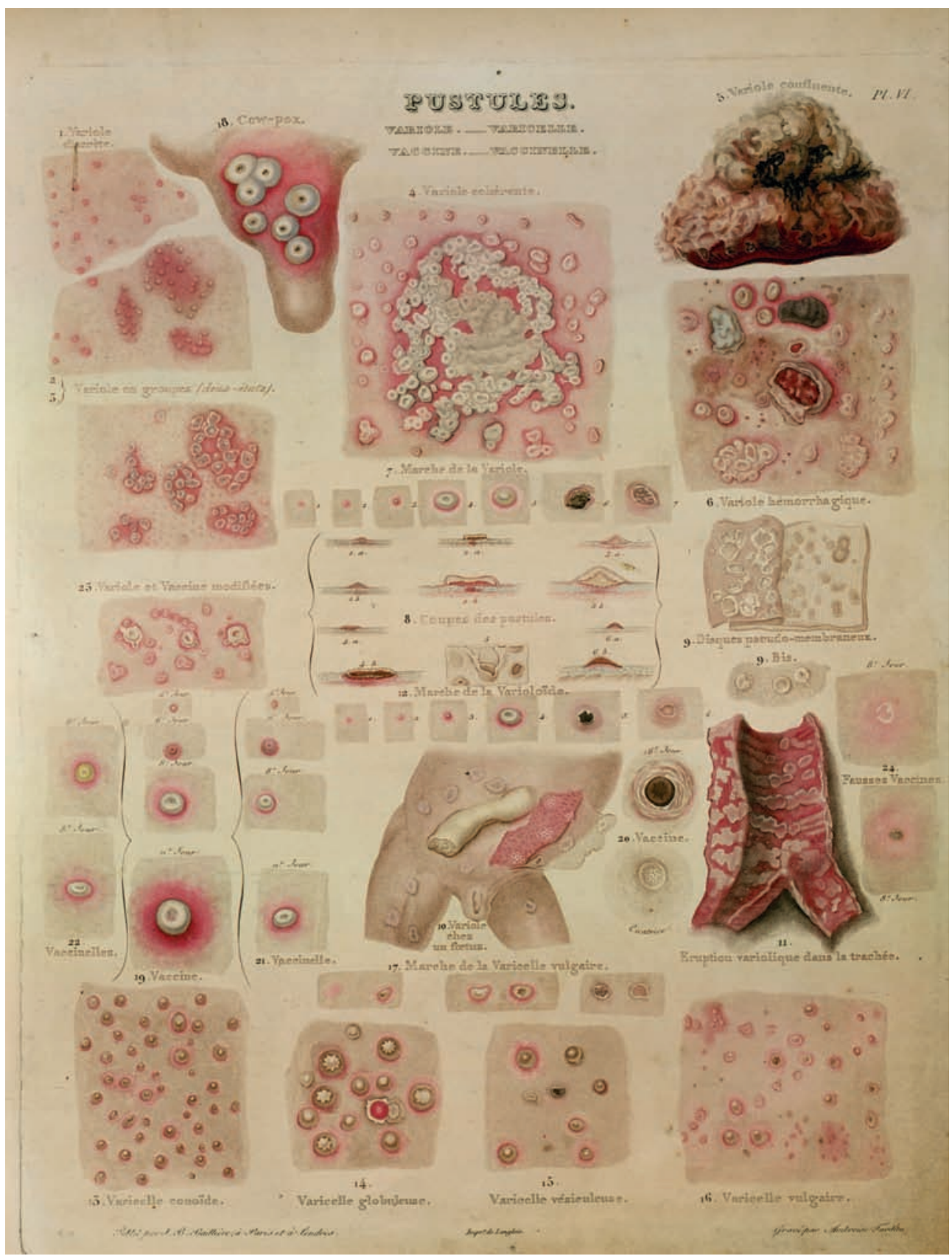

Figure 2.9 Plate 6 showing 'Pustules. Variole, varicelle, vacine, vacinelle.' In Rayer's 1835 Traité théorique et pratique des maladies de la peau: atlas. (C) BIUM Paris.

http://www.bium.univ-paris5.fr/histmed/medica/page?00584\&p=31 


\section{Chapter 2}

Apart from the emphasis on the illustrations as instructive tools in diagnostic practice, Rayer described the atlas as a 'collection' of cases and eruptions. This collection of images consisted of both individual cases and abstract patches of affected skin (see figure 2.8). In accordance with Bichat's emphasis on tissues (membranes in French) and the lesion as the elementary unit in pathology in Paris hospital medicine, Rayer was also interested in the local pathology of skin diseases. Plate VI for example shows cross-sections of variola (pustules in smallpox) (see figure 2.9). He described his subject as 'les maladies dont se compose de la pathologie cutaneé' and frequently used terms like 'membranes' and 'membraneux' in his descriptions of the plates. Although he (probably) did not use the microscope, Rayer's work would inspire the microscopic studies of skin (diseases) by German physicians later in the century (see chapter 3 in this book for an extensive analysis of microscopical investigation and depiction of skin).

Outside the Paris hospital context too physicians combined clinical and morphological depiction in their attempts to display knowledge of skin diseases visually. The German physician Friedrich Jacob Behrend (1803-1889) published his atlas of skin diseases in 1839. ${ }^{144}$ His work contained one distinctly morphological plate, but all the other plates showed collections of lesions as well as patients. Behrend himself stated that his work had an 'encyclopaedic' nature. This enabled him to use copies and parts of illustrations from the plates by Rayer and Alibert. ${ }^{145}$ As a new and cheap reproduction technique, lithography provided him with a means of producing his encyclopaedic style of depicting skin diseases. Behrend even claimed that lithography was a better technique for visualising skin diseases than copper engraving. ${ }^{146}$ The firm alliance between lithography and the depiction of skin diseases was further proved by the appearance in the course of the nineteenth century of manifold atlases with coloured lithographs of skin diseases. ${ }^{147}$

The cross-fertilisations show how the morphological and clinical depictions merged and marked the presence of a definite visual vocabulary for skin diseases. Where Willan searched for the typical in the individual (and focused on the typical), Alibert showed and assembled the specific individual cases to derive rules from them. Both approaches were inspired by natural history methods, yet they were accompanied by different

144 Behrend, F. J. (1839). Ikonographische Darstellung der nichtsyphilitischen Hautkrankheiten. Leipzig: F.A. Brockhaus.

145 Ibid., p. XI.

146 Ibid: "Es wurde Steindruck gewählt und nicht Kupferstich, um einen billiger Preis zu erzielen. Bei dem hier dazustellenden Gegenstande grade reicht die Kreidemanier auf Stein, derer wir uns bedienten, eben so weit als Kupferstich, ja in gewissem Betrachte entsprach sie undern Zwecken noch besser. Durch Kreide auf Stein lässt sich Fleisch und Haut, welches dich hier allein darzustellen war, viel weicher, saftiger, voller geben als durch irgend ein anderes Verfahren, und nur durch Kupferstich in punktirten Manier, wenn die Nadel von ganz ausgezeichneten, theuer zu erlangenden Künstlern gehandhabt wird, lässt sich Besseres erzielen. Bei Darstellung der Hautkrankheiten kommt überaus Vieles, ja fast Alles auf das Colorit an und wenn nun, wie es bei nicht ganz vorzüglichem Kupferstich fast immer der Fall, der Druck zu scharf wird und durch die aufgetragene Farbe zu deutlich hervortritt, so wird das Colorit nicht so gut, wie bei Kreide auf Stein, wo die durch den Druck gegebenen Schatten viel weniger scharf abgegränzt erscheinen und daher dem Ansehen der natürlichen Haut, wo auch die Schatten und Lichter unbestimmt ineinandergehen, ähnlicher erscheinen.

147 See Ehring, F. (1989), p. 152 ff. 


\section{Surface of recognition}

pictorial 'collections' of 'specimens'. Physicians like Rayer and Behrend combined the two ways of depiction in order to accompany new approaches to skin diseases. Mixtures of both ways of depiction now formed a common ground for physicians to deal with skin diseases. Pictures were not merely supplementary aids, but governed as a visual language of diseased skin. 
Chapter 2 


\title{
Thickening skin
}

\section{Microscopy and the science of skin}

\begin{abstract}
Um eine durch das Mikroskop erforschte Beobachtung aufzubewahren, und Anderen deutlich mitzutheilen, ist eine gute Zeichnung vielfältig unerlässlich. ${ }^{1}$

Goede afbeeldingen zijn (...) eene algemeene taal, die voor ieder verstaanbaar is, tot welken landaard hij ook moge behooren, mits hij geen volkomen vreemdeling is in de soort van onderzoek waartoe zij betrekking hebben. ${ }^{2}$
\end{abstract}

Early nineteenth-century microscopical investigations of the skin went hand in hand with drawing. In microscopical practices in Germany between 1820 and 1850 anatomists and physiologists increasingly produced drawings of the intimate anatomical structure of healthy and diseased skin. Inner structures of the skin itself were named, renamed, defined, redrawn and functionally redefined. Within the framework of new approaches to physiology and anatomy the structural nature of the skin became the object of attention. A new image of the skin materialised in microscopic pictures in a process of visual articulation. ${ }^{3}$ This chapter argues how a shared microscopic depiction of the skin emerged in the early nineteenth century. Moreover, these microscopic pictures functioned as devices for a visual rhetoric that reinforced a substantial shift in the meaning of the skin from an open porous cover towards a thick, functional and protective boundary organ of the human body.

Anatomical depictions of the skin were no innovation of the nineteenth century. Pictures of the anatomical make-up of the skin had appeared in the large anatomical atlases of the seventeenth century. Govart Bidloo's atlas Anatomia Humani Corporis (1685), for example, contained a plate with the anatomy of the skin, showing different layers and hairs. ${ }^{4}$ However, except for some early microscopical studies, the skin itself

1 Jacquin, J. v. (1829), p. 157.

2 Harting, P. (1848). Het mikroskoop, deszelfs gebruik, geschiedenis en tegenwoordige toestand. Tweede deel. Utrecht, Van Paddenburg \& Comp, p. 349.

3 The term 'visual articulation' does not imply the visualisation of a pre-existing idea. Instead, I introduce the term 'visual articulation' to refer to the way the meaning of skin came into being through its depictions in the context of microscopical investigations between 1820 and 1850. Cf. Latour's concept of 'articulation' in Prentice, R. (2005). The anatomy of a surgical simulation: The mutual articulation of bodies in and through the machine. Social Studies of Science, 35(6), 837-866.

4 On Bidloo's atlas see: Fournier, M. (1985). De microscopische anatomie in Bidloo's Anatomia Humani Corporis (1685). Tijdschrift voor de geschiedenis der geneeskunde, natuurwetenschappen, wiskunde en techniek, 8(4), 187-208; Knoeff, R. (2003). Over 'Het kunstige, toch verderfelyke gestel'. Een cultuurhistorische interpretatie van Bidloos anatomische atlas. Gewina, 26, 189-202. 
was rarely the object of investigation or depiction. More often a flayed canvas of skin would feature as a titleholder on the title page of anatomical treatises. ${ }^{5}$ It was only in the new context of the resurgent microscopical activities of the early nineteenth century that the skin became the object of intensive observation. Ever more frequently depictions were part of these studies.

While the physicians Willan and Alibert were publishing their works on the classifications of diseased skin in clinical settings, other physicians were investigating the anatomy of the skin with the help of the microscope. In recent work on the history of microscopy historians of science have noted that the renewed interest in microscopy from the 1830s onwards was related to a context of new theoretical and social frameworks and not necessarily to the technological enhancements of the compound achromatic microscope. ${ }^{6}$ In microscopical communities in Germany and Paris medical research on organs and tissues was growing. Cell theory was launched in 1839 and in the 1850s Rudolf Virchow introduced cellular pathology. ${ }^{7}$ In the climate of newly emerging microscopic communities comparative studies were also made of the structure of human and animal skin. Why this new interest in the skin? What were microscopists looking for? How were pictures involved in their research? And what did these findings imply for the scientific and medical understanding of the skin? In this chapter the depiction of the skin is taken as an activity deeply rooted in microscopical research. Not only did microscopists create pictures of the skin, the pictures were also actively involved in the construction of new ideas about the skin.

Scholars of art history and cultural studies have linked the history of the skin to a profound shift in the conception of the human body around the time of the French Revolution. This shift is often connected to Mikhail Bakhtin's argumentation of a cultural shift in perception of the body between the Renaissance and the onset of bourgeois modernity. ${ }^{8}$ The process entailed the replacement of a 'grotesque' image of the body as open and porous to a closed-off, delimited and individuated body. In her work on the body in the French Revolution historian Dorinda Outram has linked this shift to Norbert Elias' notion of Homo clausus. ${ }^{9}$ Outram argued that the dominance of the closed, individuated body image was only completed with the new political culture of the French Revolution.

5 On flaying and flayed skin see: Bohde, D. (2003). Abgeschunden, gegerbt und beschriftet - die menschliche Haut als mahnendes Schaustück in der niederländischen Anatomietradition. In U. Zeuch (Ed.), Verborgen im Buch, verborgen im Körper: Haut, zwischen 1500 und 1800. (pp. 131-137). Wiesbaden: Harrassowitz; Bohde, D. (2003). Skin and the search for the interior: The representation of flaying in the art and anatomy of the cinquecento. In F. Egmond \& R. Zwijnenberg (Eds.), Bodily extremities: preoccupations with the human body in early modern European culture. (pp. 1047). F Aldershot: Ashgate. On cultural interpretations of flaying see: Benthien, C. (2002), Chapter 4.

6 See La Berge, A. (1999). The history of science and the history of microscopy. Perspectives on Science, 7(1), 111142 , p. 136. On the history of microscopy see also: Fournier, M. (1996). The fabric of life: microscopy in the seventeenth century. Baltimore: The Johns Hopkins University Press; Ruestow, E. G. (1996). The microscope in the Dutch Republic: the shaping of discovery. Cambridge: Cambridge U.P.; Wilson, C. (1995). The invisible world: early modern philosophers and the invention of the microscope. Princeton N.J.: Princeton U.P.

7 For a review of the microscopical tradition in the history of medicine see: Bracegirdle, B. (1993). The microscopical tradition. In W. F. Bynum \& R. Porter (Eds.), Companion encyclopedia of the history of medicine (pp. 102-119). London: Routledge.

8 Bakhtin, M. (1984). Rabelais and his world (H. Iswolsky, Trans.). Bloomington: Indiana University Press.

9 Outram, D. (1989). The body and the French Revolution: sex, class and political culture. London: Yale University Press. 
Scholars writing on the historical conceptions of skin in art, literature and medicine have taken up this idea of a changing body image towards an individuated and 'sealed-off' body in the late Enlightenment. They argued for a concurrent changing conception of the skin from an open porous layer to a closed boundary limit for the body. ${ }^{10}$ Art historian Mechtild Fend explicitly associates the introduction of the term 'boundary' in the work by Xavier Bichat with the emergence of the skin as limit of the body. ${ }^{11}$ Yet most historical accounts of the body and the skin have bypassed the production of knowledge on the skin in microscopical practice. This chapter shows that the shift of body image gained currency in the production of a microscopical picture of skin in the early nineteenth century. The visual articulation of the interior of the skin in microscopic pictures defined a new idea of the relationship between the inner body and the outer milieu.

Skin pores were always at the centre of microscopical investigations of the skin. Almost invisible to the human eye, these little openings in the skin received a lot of attention from microscopists. This chapter illustrates the shift in the image of the skin by focusing on the case of the skin pores. Illustrated texts by physiologists and anatomists in Germany and France from 1820 to 1850 are used to discuss how the skin was visually redefined into a thick protective organ for the body in microscopical research processes. The first section of the chapter introduces previous research on the skin pores confirming the 'openness' of the skin in the early eighteenth century. The subsequent parts then explore the intertwined functions of illustrations in microscopical research on the skin in the early nineteenth century. Finally, I will argue that these functions of illustrations and the shift towards a thickened skin and closed-off body are closely linked developments.

\section{Open passage and present pores}

On a hot day in the summer of 1693 the Dutch microscopist Antoni van Leeuwenhoek (1632-1723) aimed his microscope at the skin of the palms of his hands:

I cleaned well, part of the Skin of my Hand, and by my Microscope, in a space not bigger than a Sand, I saw the Sweat issuing out at about Fifty places, which as they touched, joined together into one little Bubble. After drinking about a Quart of French-Wine over Night, I found myself a little out of order the next morning, at Dinner I drank a Pint and half more, and after about Two Hours, I drank Half a pint of Tea very hot, that I might throw my self into a Sweat; (...) I examined it (...). I made this Experiment, to see if any of the salt Particle to be found in my Sweat, were like those found in Wine. ${ }^{12}$

10 Benthien, C. (2002), p. 37; Fend, M. (2005).

11 Fend, M. (2005), p. 314.

12 Leeuwenhoek, A. van (1693). An extract of a letter from Mr. Anthony Van Leeuwenhoek, to the R. S. containing his observations on the seeds of cotton, palm, or date-stones, cloves, nutmegs, goose-berries, currans, tulips, cassia, lime-tree: On the skin of the hand, and pores, of sweat, the crystalline humour, optic nerves, gall, and scales of fish: and the figures of several salt particles, etc. Philosophical Transactions, 17, 949-960; p. 954-955. 


\section{Chapter 3}

Van Leeuwenhoek's description of the microscopical inspection of his sweat referred to the idea of the skin as an open passageway for bodily fluids and substances. More specifically, Van Leeuwenhoek assumed that sweat was transported through the skin by means of 'pores'. ${ }^{13}$ Pores though were not specific features of the skin per se. In other microscopic investigations of the roots and seeds of plants Van Leeuwenhoek also observed parts "full of Pores". ${ }^{14}$

Apart from Van Leeuwenhoek, other microscopists also made observations of the human skin in the late seventeenth century. In the context of mechanical philosophy microscopic activities flourished between the 1660s and 1690s. The well-known English botanist and microscopist Nehemiah Grew (1641-1712) had published his investigations of the skin in a short piece in the Philosophical Transactions in $1684 .{ }^{15} \mathrm{In}$ his descriptions Grew indicated how the existence of pores in the skin was a general and unquestioned matter for physicians:

By Pores, Physicians mean no more, than certain permeable spaces between parts of a Body.

Wherefore, that there are Pores in the skin of every man's Body, is no more to be question'd, than whether Men do ever Sweat or Perspire. ${ }^{16}$

Grew's observations focused more in particular on the pores in the hands and feet, which were "hitherto (...) described by no Anatomist", Grew declared. ${ }^{17} \mathrm{He}$ observed the skin with an "indifferent Glass" and included a figure of the pores standing in rows upon the "Ridges" of the palm of the hand, each pore like "a little Fountain" producing sweat (see figure 3.1). According to Grew, the pores functioned as an open passage for the discharge of "perspirable" and "noxious" parts of the blood "which by the continual use of the Hands and Feet, are plentifully brought into them". ${ }^{18}$ This was why, Grew argued, the sweat of the feet with many people "is much more offensive than any other part of the Body". ${ }^{19}$ The pores were therefore thought to form a continuous open communication pathway between the body and its environment.

The concept of the skin as an open, porous envelope dominated thinking about the body and diseases well into the eighteenth century. Grew's findings in particular served as the starting point for physicians working on skin and skin diseases. In De morbis cutaneis (1714) the London surgeon Daniel Turner relied upon Grew's observations of the pores to explain the excretions and uptake of substances by

13 Ibid., p. 955.

14 Ibid., p. 950.

15 Grew, N. (1684). The description and use of the pores in the skin of the hands and feet, by the learned and ingenious Nehemiah Grew, M.D. Fellow of the College of Physicians and of the Royal Society. Philosophical Transactions, 14, 566-567.

16 Ibid., p. 566.

17 Idem.

18 Ibid., p. 567. Italics in original.

19 Idem. 


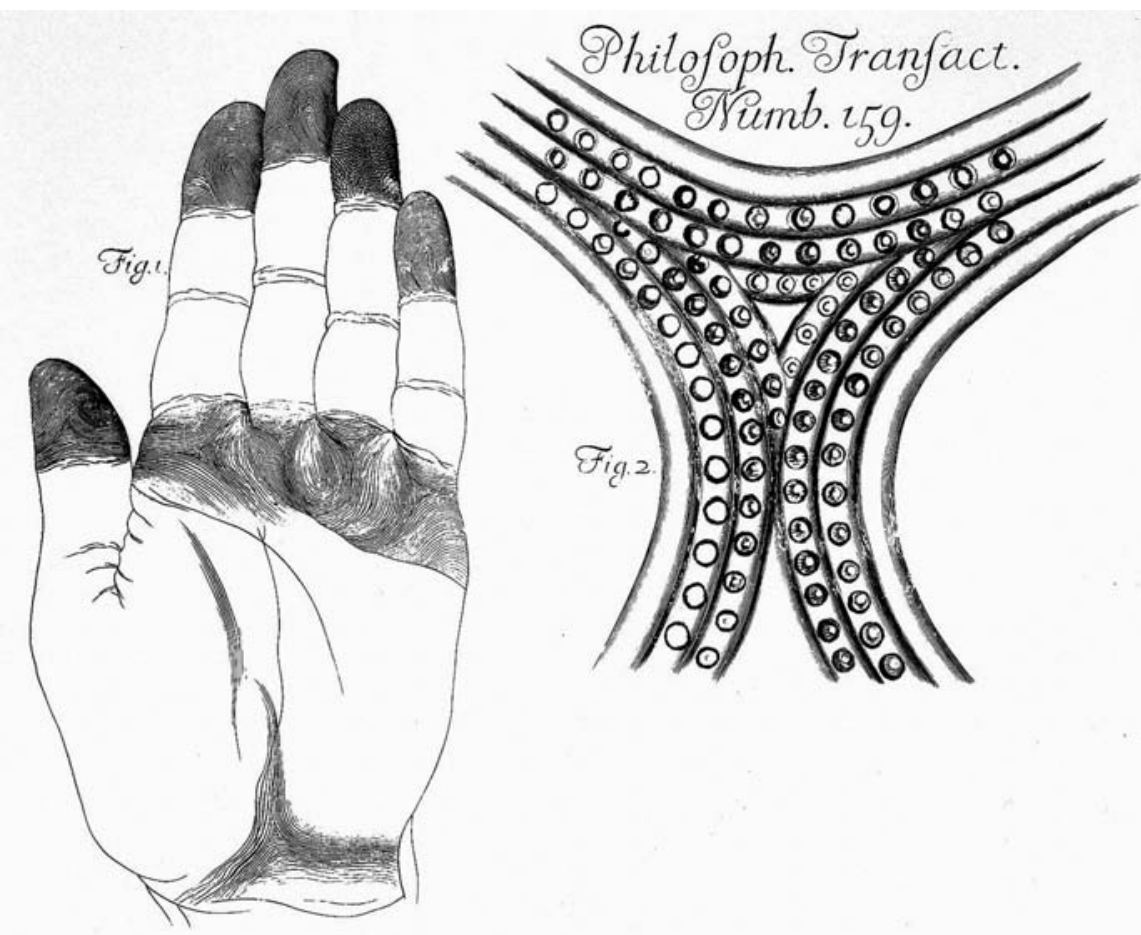

Figure 3.1 Grew's depiction of the pores in the skin. (1684). In Philosophical Transactions $(24 \mathrm{~cm})$. Wellcome Library, London.

the skin. ${ }^{20}$ The openness of the body in the seventeenth and eighteenth centuries was not therefore limited to the passage of sweat through the skin out of the body. When discussing the entrance of 'outward' origins of diseases, Turner referred to the skin pores. Medical historian Philip Wilson describes Turner's ideas about pores as follows:

Turner claimed that the precise aetiology or 'efficient Cause' of most internal distempers consisted of 'immaterial Beings' that were 'imperceptible' to the senses. Each skin pore, he continued, offered a 'sufficient [entry] Passage' for the 'cause' of apoplexy, epilepsy, 'convulsive and hysterical' disorders, and 'Pestilential' diseases, including the plague. ${ }^{21}$

So for Turner, as indeed for his contemporaries, the skin pores served as passageways in the spreading of diseases from the surrounding environment to the inside of the body. Artificially closing off the pores, however, was unwise, for that could cause dangerous

20 See Wilson, P.K. (1992), p. 69 note 53: Wilson notes how Turner copied much of the account of Grew in De morbis cutaneis. See Turner, D. (1714).

21 Wilson, P.K. (1992), p. 67. 


\section{Chapter 3}

fevers. Moreover, relieving blocked pores by sweat-inducing remedies, for example, formed an important task for physicians, as claimed by Turner and his colleague physicians. ${ }^{22}$ Bathing too was hazardous, because the water was able to pass through the pores into the body and disturb organs and functions. ${ }^{23}$

Eighteenth century accounts of bodily experiences by patients confirm the openness of the body and the porous conception of the skin. In her work on the medical histories of women in the writings of the German physician Johannes Storch (1681-1751) Barbara Duden points to the conception of the skin as an open system. ${ }^{24}$ In accordance with the humoural body, the skin pores were seen as bodily orifices and points of entrance or exit, like the eyes, nose, breasts, anus and navel..$^{25}$ The skin was "made permeable from the inside: it has "sweat holes" which heat could open to allow the discharge of humidity, bloody matter, and impurities" ${ }^{26}$ Similarly, patients of the Swiss doctor Samuel Tissot (1728-1797) referred in their accounts to their evacuations from the bodily interior to the exterior. ${ }^{27}$ Medical historians Pilloud and Louis-Courvoisier have used the term 'porosity' in their characterisation of the body in the accounts of Tissot's patients. ${ }^{28}$ Porosity implies "an exchange between interior and exterior of the body" ${ }^{29}$ Pilloud and Louis-Courvoisier maintain, however, that the openness of the body to the world in these accounts should not be delimited to the corporeal level: "The body is submitted to a logic that is both physiological and moral, maintaining its integrity only through a fluidity of exchanges between interiority and exteriority". ${ }^{30}$ Body and environment were both open to each other, with the skin pores as one of the important orifices for exchange.

By the early decades of the nineteenth century the conceptualisation of the skin pores changed. Although microscopy had flourished in the seventeenth century, the instrument was relatively little used in the eighteenth century, at least not for scientific purposes. In the early nineteenth century, however, the tool was reintroduced for scientific analyses and used in a widespread investigation into the physiology and anatomy of the human body. Within a few decades the microscopical exploration of the anatomical structure of the skin had put an end to the skin as open cover of the body. The image of an open, porous skin was replaced by a new image. In the early nineteenth century the skin, with the help of the microscope, was visually articulated as a functionally active, thick organ.

22 Ibid., p. 67.

23 Vigarello, G. (1988). Concepts of cleanliness: changing attitudes in France since the Middle Ages (J. Birrell, Trans.). Cambridge: Cambridge University Press, p. 95.

24 Duden, B. (1991). The woman beneath the skin: a doctor's patients in eighteenth-century Germany (T. Dunlap, Trans.). Cambridge, Mass: Harvard University Press.

25 Ibid., p. 120.

26 Ibid., p. 121.

27 Pilloud, S., \& Louis-Courvoisier, M. (2003). The intimate experience of the body in the eighteenth century: between interiority and exteriority. Medical History, 47(4), 451-472.

28 Ibid., p. 470.

29 Idem.

30 Ibid., p. 472. 


\section{Skin as object of investigation}

In the 1820 s and 1830 s the skin became the object of several types of analysing practice. At universities in the German states in particular anatomists, physiologists and physicians studied different aspects of the skin. Two aspects of their analyses were particularly prominent: the skin pores and tactile sense. Examinations into these aspects reconstructed the skin within changing perspectives on physiology and anatomy. In this section I give an outline of the context in which the microscope was deployed to study the skin and in which pictures were produced. What studies were done on the skin in the early nineteenth century?

In the course of the nineteenth century physiology and anatomy separated as disciplines. Experimental physiology replaced old anatomy and old physiology as a dominant discipline "for the investigation and discussion of the phenomena of life in the human and the animal". ${ }^{31}$ In France François Magendie introduced a physiology that took animal experiments as the starting point for the study of bodily functions. ${ }^{32}$ Not the anatomical facts, but the outcomes of experiments served as insights into bodily processes. Historians of science have widely acknowledged this shift towards "a concept of bodily functions independent of anatomical structures" in the context of Romantic Naturphilosophie..$^{33}$ Between 1770 and 1820 changes in the institutional German academic structure went hand in hand with new ideas about knowledge acquisition of the body. ${ }^{34}$ In the newly established German system the body became the subject of a thorough investigation. Anatomists and physiologists took part in a large-scale investigatory enterprise to disclose the functions and morphological structure of bodily tissues.

In the context of changing perspectives on physiology the skin became an interesting object for investigation. Physiologists were first primarily interested in the secreting and the tactile functions of the skin. Both aspects were initially part of the larger researches of sense physiology. Sense physiologists at German universities such as Johannes Müller (1801-1858) and Jan Evangelista Purkinje (1767-1869) conducted experiments to study sensual perception (vision, speech and hearing). Both Purkinje and Müller came under the influence of Germany's most eminent anatomist, Carl Rudolphi (17711832). Rudolphi held the chair of anatomy and physiology at the University of Berlin, where Müller started his career in 1822, at around the same time that Purkinje started in Breslau. ${ }^{35}$ Although Rudolphi was critical of the speculative tendencies of Purkinje's

31 Cunningham, A. (2002). The pen and the sword: recovering the disciplinary identity of physiology and anatomy before 1800. I: Old physiology - the pen. Studies in History and Philosophy of Biological and Biomedical Sciences, 33, 631-665; quoted from p. 632.

32 Idem. For a general overview see also: Hagner, M. (2003). Scientific medicine. In D. Cahan (Ed.) From natural philosophy to the sciences (pp. 49-87). Chicago/London: The University of Chicago Press.

33 Hagner, M. (2003), p. 64.

34 Broman, T. H. (1996). The transformation of German academic medicine, 1750-1820. Cambridge: Cambridge University Press.

35 Steudel, J. (1975). Müller, Johannes Peter. In C. C. Gillispie (Ed.) Dictionary of scientific biography (p. 568). New York: Charles Scribner's Sons. 


\section{Chapter 3}

research, he still agreed with his approach to physiology. ${ }^{36}$ Key to this new approach was the experimental study of sensations. This specific methodological approach in sense physiology was denoted by historian of science Jutta Schickore as exploring "how experience allows the subject to acquire objective knowledge". ${ }^{37}$ Schickore studied the early works of Johannes Müller to discuss how he dealt with the problem of the subject-object relationship in sense physiological experiments on vision. However, sense physiologists also analysed the skin in empirical research.

We can find such an experimental approach to the skin, as well as attention to the tactile sense and excretion, in the early work of Jan Evangelista Purkinje. Purkinje (1767-1869) was appointed professor of physiology at Breslau in $1823 .{ }^{38}$ In his medical Habilitationsdissertation of 1823, Commentatio de Examine Physiologico Organi Visus et Systematis Cutanei, Purkinje's subject matter revealed his interest in bodily dependency of sensory experience. ${ }^{39}$ Purkinje proposed a so-called "Individual-physiology", with the empirical investigation of an individual organism or organ as the basic principle. ${ }^{40}$ Next to the physiological investigation of the eye, Purkinje described his physiological examination of the skin. In contrast to the seventeenth-century microscopists who studied the skin, Purkinje considered the skin as a physiological object of empirical investigation.

Purkinje's experimental analysis in his Commentatio shows how the skin emerges as an object of investigation through the experience of the researcher. As with some other sense physiologists, Purkinje concentrated his investigations on the function of the senses by means of self-experimentation. His description of the physiology of the skin was based on his own experience of the skin with the senses. He discussed the feeling, the looks, the smell and the sensations of the skin. Tactile experiences such as dryness, moistness or rigidity of the skin surface were put alongside the different possible outward appearances, colours and feelings of pain or coldness. In this way all the different senses were deployed empirically to acquire knowledge about the skin. The examination of the skin using all the senses included the contact between the skin of the researcher and the skin as a research object. Purkinje warned the reader in this respect that the subjective properties of the researcher's skin, such as dryness or dampness, should not be confused

36 Coleman, W. (1988). Prussian pedagogy: Purkyne at Breslau, 1823-1839. In W. Coleman \& F. L. Holmes (Eds.) The investigative enterprise: experimental physiology in nineteenth-century medicine (pp. 15-64). Berkeley Calif.: University of California Press, p. 18.

37 Schickore, J. (2003). The 'philosophical grasp of the appearances' and experimental microscopy: Johannes Müller's microscopical research, 1824-1832. Studies in History and Philosophy of Biological and Biomedical Sciences 34, 569592; p. 581.

38 Kruta, V. (1975). Purkyne (Purkinje), Jan Evangelista. In C.C. Gillispie (Ed.) Dictionary of scientific biography (p. 214). New York: Charles Scribner's Sons.

39 Purkyne, J. E., Kruta, V., Ebert, J., Zlábek, K. (1979). Abhandlung über die physiologische Untersuchung des Sehorgans und des Hautsystems / von Johann Evangelista Purkyn ; übers. von Joachim Ebert und Karel Žlábek; eingeleitet und erläutert von Vladislav Kruta. Halle/Saale: Deutsche Akademie der Naturforscher. Leopoldina. Original publication: Purkyne, J. E. (1823). Commentatio de Examine Physiologico Organi Visus et Systematis Cutanei. Vratislaviae: Typis Universitatis.

40 Purkyne, J. E., Kruta, V., Ebert, J., Zlábek, K. (1979), pp. 9-10. 
with the observed properties of the skin as object. ${ }^{41}$ When in doubt, Purkinje proposed the alternate use of the back and the front of the hand or even feeling with the nail. The nails and hair too were for that matter themselves objects of investigation for Purkinje. ${ }^{42}$ Since the hair and nails had their origin in the epidermis, they also had to be examined. Purkinje suggested observing the following features of the nails and hair in a number of individuals: the thickness of hairs, their length and fineness, their curve and direction, how they grow out of the skin, form, structure, colour, transparency, firmness or softness, solidity, electricity, hygroscopic quality and chemical composition. ${ }^{43}$ In addition to these physical qualities, Purkinje argued that the qualities of nails and hair were also important for the skin as an organic system. The hair and nails formed parts of the skin system and so were tackled with a similar empirical method. In Purkinje's approach the whole skin system was made into a physiological object for empirical observation.

The excreting function of the skin also attracted Purkinje's attention. He defined the skin as a "system" ${ }^{44}$ Apart from its sensory qualities the skin, according to Purkinje, had an "organic conformation". ${ }^{45} \mathrm{He}$ considered the pores as important parts in the configuration of the epidermis, the outermost layer of the skin. When discussing the skin pores, Purkinje referred to the ongoing controversy about the existence of skin pores at the time. The physiologist Alexander von Humboldt (1769-1859), for example, had searched in vain for the pores with a compound microscope using 312-fold magnification. ${ }^{46}$ Purkinje himself explained that pores were present in the epidermis, but they were hidden and invisible to the naked or 'armed' eye because of the elasticity of the surface. ${ }^{47}$ To the pores Purkinje ascribed the function of sucking in blood and the secretion of sweat or blood. ${ }^{48}$ They were connected to channels that allowed the passing of liquids, even though these channels too were not visible in a small section of skin. Yet the existence of the channels was proven by the results of the excretion and suction, the sweat and the blood. Furthermore, Purkinje argued that the blockage of the pores in old age caused and explained the slower skin function in aging people. ${ }^{49}$ The pores were not visible, but they nonetheless existed according to Purkinje. The idea of an open skin remained intact, but Purkinje's experimental and experiential investigations marked the onset towards another conception of skin.

In the years following Purkinje's dissertation of 1823 other researchers adopted a

41 Ibid., p. 36.

42 Ibid., p. 47.

43 Ibid., p. 47: "Pilorum frequentia, longitudo, et exilitas, flexio atque e cute procrescentium directio, figura, structura, color, pelluciditas, durities aut mollities, firmitas quae tensioni resistit aut facile cedit, electricitas, qualitas hygroscopica, immo si fieri potest chyemica mixtio, in diversis individuis inquisitioni subjiciantur."

44 Systematis Cutanei.

45 Purkyne, J. E. (1823), p. 39: "Jam ab hisce mere sensualibus cutis propriatibus transgredior ad organicam ejus conformationem."

46 Eichhorn, H. (1826). Ueber die Aussonderungen durch die Haut und über die Wege, durch welche sie geschehen. Archiv für Anatomie und Physiologie, 405-486; p. 29.

47 Purkyne, J. E., Kruta, V., Ebert, J., Zlábek, K. (1979), p. 125. The 'armed' eye points to the use of a magnifying glass.

48 Purkinje (1823), p. 39.

49 Ibid., p. 40. 
similar experimental attitude towards the skin. Excretion and tactility remained the main focus in these studies. Purkinje had conducted his analysis of the skin with a magnifying glass, as did two German physiologists after him. In 1826 and 1827 two papers on the excretion of the skin were published in the Archiv fir Anatomie und Physiologie. The German physician Heinrich Eichhorn from Göttingen wrote a lengthy paper on the excretions "through" the skin in $1826 .{ }^{50}$ A year later Ernst Heinrich Weber (17951878), professor of anatomy in Leipzig, published on his observations of the skin, the skin glands and hair. ${ }^{51}$ Weber would later further publish on his experimental studies of cutaneous sensations using a compass. ${ }^{52}$

Both articles exemplify the doubts about the character of skin pores and the controversy about excretions by the skin at this time. Ernst Weber's description of the pores and the skin shows particularly well how he handled the skin as an object of physiological investigation, focusing on empirical knowledge about form and function. In previous years several physiologists had tried to prove the existence of skin pores in experiments. Yet nobody had been able to find the pores as described and depicted by Grew in $1684 . .^{53}$ Weber put one of the physiological experiments from 1823 to the test. The French anatomist Pierre Béclard attempted to press mercury through the skin pores in an experiment in $1823 .{ }^{54}$ Béclard also found that manually introduced openings (produced with needles) in a piece of "Oberhaut" were neither visible with the naked eye nor with a magnifying glass. ${ }^{55}$ Weber now repeated and confirmed Béclard's findings. Weber concluded that the elasticity of the skin concealed the openings and that the role of light in mechanical enlargement with magnifying glasses and the microscope made it impossible to observe small openings under a high magnification. ${ }^{56}$ In an emerging debate on microscopy the erroneous role of light in observation became an important epistemological and methodological point of interest. ${ }^{57}$ For Weber, however, this problem explained his failure to locate and prove the existence of the skin pores experimentally.

The porous nature of the skin became a contested issue in the early nineteenth century. Weber's vocabulary in his article from 1827 in the Archiv für Anatomie und Physiologie is telling. Particularly interesting is the multiplicity of his terms referring

51 Weber, E. H. (1827). Beobachtungen über die Oberhaut, die Hautbälge und ihre Vergrösserung in Krebsgeschwülsten und über die Haare des Menschen. Archiv für Anatomie und Physiologie, 198-225.

52 See: Weber, E. H. (1835). Ueber den Tastsinn. Archiv für Anatomie, Physiologie und wissenschaftliche Medicin, 152-160; Weber, E. H. (1846). Der Tastsinn und das Gemeingefühl. In R. Wagner (Ed.) Handwörterbuch der Physiologie: mit Rücksicht auf physiologische Pathologie. Dritter Band (pp. 481-588). Braunschweig: Vieweg. For studies of Weber's works see: Bueck-Rich, U. (1970). Ernst Heinrich Weber (1795-1878) und der Anfang einer Physiologie der Hautsinne. Juris: Zürich; Hoffmann, C. (2001). Haut und Zirkel. Ein Entstehungsherd: Ernst Heinrich Webers Untersuchungen „Ueber den Tastsinn“. In M. Hagner (Ed.) Ansichten der Wissenschaftsgeschichte (pp. 191-223). Frankfurt: Fischer.

53 Weber, E. H. (1827), pp. 198-199.

54 Béclard, P. A. (1823). Élémens d'anatomie générale ou description de tous les genres d'organes qui composent le corps humain. Paris: Béchet.

55 Weber (1827), p. 199.

56 Ibid., p. 199.

57 See: Schickore, J. (2001b). Ever-present impediments: Exploring instruments and methods of microscopy. Perspectives on Science 9 (2), 127-146. 
to sebum (skin smear) producing parts in the skin. Weber was convinced that special sebum producing "organs" were present in the skin..$^{58}$ Nonetheless, Weber used different labels for these organs. He referred to "Hautbälge", "Talgdrüsen", "glandulae sebaceae", "Balgdrüsen" and "Hautdrüsen". ${ }^{59}$ This mixed vocabulary indicates a transition to a conception of an excreting skin with its own producing structures inside.

The article by the German physician Eichhorn similarly emphasised the ambiguity of the position of the sweat pores. One of Eichhorn's explicit goals was to prove that in the early eighteenth century Van Leeuwenhoek had not seen pores for the exchange of fluids through the skin in his microscopical observations. Instead, Eichhorn claimed that the different secretions, such as sweat and sebum (skin smear), were excreted through "sweat pores" and by sebum producing glands of the hairs. After performing several observations, dissections and experiments, Eichhorn happily concluded that he had found the "sweat pores" with "sweat channels" of the skin: "Das Auffinden der Sweissporen mit ihren Canälchen hat mir in jeder Hinsicht ausserordentlich viel Vernügen gemacht; denn es ist damit gegangen, wie mit dem Ei des Columbus" ${ }^{60}$ The description of his empirical experiments had been the only way for Eichhorn to prove the existence of the "sweat pores" ${ }^{61}$ His account comprises over 50 pages of descriptions and instructions for observation. Also, several precautions had to be taken in order actually to find the pores: a simple magnifying glass was essential, ${ }^{62}$ proper positioning of the skin with the sweat was necessary and of course one should follow the directions as given by Eichhorn. ${ }^{63}$ Similarly, precautions had to be taken to find the so-called "sweat channels" in specimens of skin from a dead body. A piece of skin was placed in cold water. Then boiling water was added, with constant movement of the cup containing the skin specimen, until one was able to remove the top layer of the skin with a pair of tweezers. ${ }^{64}$ After this preparation the small sweat transporting channels would become visible. In both cases, with either the 'live' skin or the dead specimen, the skin was handled and shaped in such a way that the pores or channels would become visible to the observer. This means that the existence of the sweat pores as claimed by Eichhorn became entwined with an empirical-physiological method and context.

Eichhorn's 'sweat pores' were not the same as Van Leeuwenhoek's pores in the skin. ${ }^{65}$

58 Weber (1827), p. 203.

59 Ibid., pp. 202-208. "Talgdrüsen" may be translated as tallowglands.

60 Eichhorn, H. (1826), p. 475.

61 "Es will mir daher doch fast etwas anmasslich vorkommen, wenn mir hin und wieder wohl Aerzte gesagt haben: dass Schweissporen da seyn müssen, haden wir naturphilosophischen Aerzte schon lange gewusst, das sinnliche Wahrnehmen ist dabei ja gar nicht nothwendig, das ist überall etwas Triviales. Diese Herren wissen freilich alles durch die unmittelbare Anschauung des Absoluten. (...) ....als bis mir durch sinnliche Wahrnehmung ein anderer Glaube in die Hand gethan würde; so habe ich denn so bei mir gedacht, es sey doch wohl recht gut, noch einmal nach den Schweissporen recht ordentlich zu suchen." Eichhorn (1826), p. 419.

62 Eichhorn emphasised the use of a single magnifying glass in his studies of the sweat pores. Larger magnifications of a compound microscope for example, could lead to dangerous deceptions. See Eichhorn, H. (1826), on note 1 p. 423 and pp. 430-431.

63 Ibid., pp. 429-431: "\$54. Vorsichtsmassregeln bei der Aufsuchung der Schweissporen am lebenden Körper."

64 Ibid., p. 432.

65 Eichhorn refers to Van Leeuwenhoek's microscopical observation of the pores in the year 1717, see p. 476 in Eihchorn, H. (1826). 
According to Eichhorn, Van Leeuwenhoek's methods had not provided him with the right conditions to see the pores (as seen by Eichhorn). ${ }^{66}$ The way Van Leeuwenhoek had operated would have made it impossible to see the pores, Eichhorn argued. By putting the entire skin under the microscope, pressure would prevent anything from being seen at all. ${ }^{67}$ Only by following Eichhorn's preparations would the sweat pores become visible. Eichhorn's pores differed from Van Leeuwenhoek's. In his article Eichhorn himself referred to this difference between his pores and the pores found by Van Leeuwenhoek. Eichhorn quoted naturalists and physiologist Johann Friedrich Blumenbach, who reacted to Eichhorn's specimens with the sweat channels: "Das sey ganz etwas Anderes, als mit den Leeuwenhoekschen Poren" ${ }^{68}$ Similarly, Eichhorn explicitly distinguished between his pores and the ones observed during investigations by others. With regard to the pores observed by the German anatomist Friedrich Osiander Eichhorn explained: "jedoch das sind ganz andere, als die von mir aufgefundenen [Poren]". ${ }^{69}$ In the theoretical, methodological and practical arrangements of Eichhorn's context different pores were produced compared to the early eighteenth-century context of Van Leeuwenhoek and others.

For both Eichhorn and Weber the skin became an object of physiological observation and experiment in the 1820s. They studied the excreting function of the skin and the problem of the existence of the skin pores associated with it. Their studies mark a turning point in the assumptions about the open porous nature of the skin. In the next decade microscopical studies into the anatomy of the skin would build on physiological investigations and the interest in skin as an object of investigation. Microscopic studies consequently further changed the ideas about the skin pores in a visual manner.

\section{Visual articulation of the skin interior}

In the 1830s closer microscopical observations of healthy skin followed physiological interest in the skin. By then microscopists in Germany and France (Paris) were especially interested in the skin structures involved in excretion. Analysis of skin physiology now demanded more insights into the structure of the skin as well, according to those studying the skin. In contrast to the previous physiological studies of the skin, the microscopic studies of the intimate composition of the skin included multiple illustrations. These illustrations mattered. They visually exposed the interior of the skin and its 'newly' discovered elements. Now the 'mysteries of the organisation' of the skin were the focus of investigations. ${ }^{70}$ In scientific publications a new schematic image of the interior of the skin was put to the fore in microscopical depictions.

66 Ibid., pp. 476-477.

67 Ibid., p. 477.

68 Quoted in Eichhorn, H. (1826), p. 476.

69 Eichhorn, H. (1826), p. 484. Emphasis in original.

70 The French anatomists Breschet and de Vauzème referred to "les points les plus mystérieux de l'organisation" of the skin in: Breschet, G., \& de Vauzème, A. R. (1835). Nouvelles recherches sur la structure de la peau. Paris: J.-B. Ballière, p. 3. 
A renewed interest in microscopy emerged in German universities from the 1830s. In Breslau Purkinje - now holding the chair of physiology - introduced his students to the Plössel microscope, a new and powerful achromatic instrument. ${ }^{71} \mathrm{He}$ obtained the microscope in 1832, which marked the onset of a new period in his research. ${ }^{72}$ With some of his students Purkinje started a collective research project devoted to the study of the microscopic anatomy of human tissues. ${ }^{73}$ This research contributed to the later creation of human histology. Purkinje's enthusiasm for the application of the microscope for physiological investigations was reflected in his contribution on microscopy to Wagner's Handwörterbuch der Physiologie from 1844:

Oder endlich richtet sich das Sehen nach den kleinsten mit dem bloßen Auge nicht mehr unterscheidbaren Theilchen mit hülfe des Mikroskops; dies ist die Aufgabe der Mikrotomie und Mikroskopie. Das letzte Ziel dieser Art Forschung ist die vollkommne Durchsichtigmachung alles räumlich Gebildeten und so das volle Bewußtwerden alles Sichtbaren. ${ }^{74}$

Purkinje praised the microscope for its ability to visualise the smallest objects invisible to the naked eye in scientific enquiries. Microscopy enabled visualisation of the smallest interior elements of the skin as well.

From the mid-1830s microanatomists analysed the structure of skin tissues. In 1833 one of Purkinje's students, Alphons Wendt, wrote his medical Inauguraldissertation on the human epidermis. ${ }^{75}$ The text appeared in Latin, but a German translation of the work was published in Johannes Müller's Archiv für Anatomie, Physiologie und wissenschaftliche Medicin in $1834 .{ }^{76}$ In the article Wendt reported on his microscopical observations of the structure of the epidermis, the outermost layer of the skin. One of his most spectacular descriptions concerned the microscopical observation of the 'sweat channel' as a neatly delimited 'organ' in the skin. ${ }^{77}$ Contrary to existing ideas about the secretion of sweat, which assumed the transportation of sweat through the skin. Wendt found that the sweat was produced inside the skin itself:

Es ist daher klar, dass das von Früheren über die Schweissecretion Gesagte nicht richtig ist; dass diese Fäden den Schweiss nach aussen führen, leidet wohl keinen Zweifel; da aber ihr unteres Ende verschlossen ist, so muss auch der Schweiss in die Höhlen derselben abgesondert werden, (...). Wir müssen die daher, wie die Hauttalgdrüsen, als einfache Drüsen betrachten. ${ }^{78}$

71 Coleman, W. (1988), p. 24.

72 Kruta, V. (1975), p. 216.

73 Coleman, W. (1988), p. 21.

74 Purkyne, J. E. (1844). Mikroskop. In R. Wagner (Ed.), Handwörterbuch der Physiologie: mit Rücksicht auf physiologische Pathologie. Zweiter Band (pp. 411-441). Braunschweig: Vieweg.

75 Wendt, A. (1833). De epidermide humana. Vratislav.

76 Wendt, A. (1834). Ueber die menschliche Epidermis. Archiv für Anatomie, Physiologie und wissenschaftliche Medicin, 278-291.

77 Ibid., p. 285.

78 Ibid., p. 290. 


\title{
Chapter 3
}

By comparison, Weber, Eichhorn and others had written about the excretion of sweat through the skin. Wendt's microscopical observations proved a different composition of the skin. No longer did a direct opening connect the body with its environment. Instead, a new structure inside the skin was specified in microscopical observations.

The observations in Wendt's article mark a shift towards a novel way of thinking about the excretion of sweat and the openness of the skin. Wendt himself stressed the importance of the new sweat threads or "Fäden" as he called them. He noted that it was initially his master Purkinje who had observed the structures in a prepared specimen of skin of the inner hand. Wendt had subsequently elaborated on Purkinje's observations:

\begin{abstract}
Purkinje, der die auf diese Weise behandelte Epidermis der Handfläche untersuchte, machte zuerst eine für die nähere Kenntniss der Schweisswege höchst wichtige Entdeckung. Er bemerkte unter den Grübchen der Epidermis fadenförmige, genau begrenzte Organe, die aus der Cutis hervorkommend, in häufigen spiralen Windungen zu den Grübchen emporsteigen. Bei fortgesetzter Untersuchung fand ich, dass diese Fäden (...) verschiedene Formen annehmen. Das Ende des Fadens in der Cutis war wegen des mannigfach verwickelten Gewebes dieser Membran schwer zu finden, (...), zuweilen aber lag diess Ende klar vor (...) und schien mit abgerundetem, geschlossenem Grunde zu endigen. ${ }^{79}$
\end{abstract}

The terms "Ende", "genau begrenzte Organe" and "geschlossenem" are particularly significant here. These words indicate that there was no more talk of direct passage through the skin. The concept of the pores as closed holes was an important claim that indicated a transformation in the image of the skin. The skin no longer seemed an open passageway for transportation, but more a mediating organ harbouring functionally organised structures and processes of its own.

Moreover, the microscopical observations of the new structure inside the skin entailed a particular visual specification as well. The illustrations of the sweat 'Fäden' functioned as a visual articulation of the newly found structures. Wendt's article contained six illustrations. The third figure of the engraved plate (Tab. IV in the journal) showed the different forms of the Fäden (see figure 3.2). In his explanation of the illustrations Wendt wrote that the picture showed the course of the "Spiralfäden", yet another name for the same new structure. ${ }^{80}$ Wendt further explicitly indicated that the illustration depicted the structure of the Fäden. ${ }^{81}$ In a very schematic way the illustration reinforced the idea of the structure as a little 'sack' with a closed side. ${ }^{82}$

However, the new structure needed specific instrumental and methodological circumstances to become visible under the microscope. First, a particular preparation of

79 Ibid., p. 285.

80 Ibid., p. 291.

81 Ibid., p. 288: "Wir habe der beschriebenen Formen in der dritten Figur abbilden lassen. Ihre Structur scheint auch einfach körnig und polypös, wie den oberen Theilen zu seyn.”

82 With regard to the tallow-glands, Wendt used the term 'sack': "(...) Säcken die von der Epidermis ausgingen, mit abgerundetem Ende sich in die Cutis einsenkten und mit der oeffnungen in der Epidermis genau zusammenbringen.”. Wendt (1834), p. 281. 


\section{Thickening skin}

the specimen was necessary: a piece of skin needed to be treated with liquid potassium carbonate, which made the layers transparent and solid as well, making it easier to cut the piece into small slices with a sharp knife. ${ }^{83}$ Second, the spiralled structure would only become visible under the microscope with the right focus of the lens. ${ }^{84}$ The visualisation of the structure was therefore restrained by controlled preparation and instrumental methodology. Historian of science Jutta Schickore has referred to the importance of these quantitative physical and chemical methods for microanatomists in the 1830 s to gain control over their objects. ${ }^{85}$ She shows how increased methodological control by microanatomists in the microscopical study of the retina led to a more complex inner structure of the retina. ${ }^{86}$ In the case of the visualisation of the new structures in the skin with the microscope, the right preparation and observation methods were indispensable. Visualisation thus presumed a greater experimental conditioning of the skin as a subject of microscopical study.

Hundreds of miles from Breslau anatomists in Paris were also interested in the microscopic structure of the skin. In 1834 Gilbert Breschet and Augustin Roussel de Vauzème published their new investigations into the structure of the skin in the Annales des Sciences naturelles. ${ }^{87}$ The main author, Gilbert Breschet (1784-1845), was a surgeon at the Hôtel Dieu and professor of anatomy at the Faculté de Médecine in Paris. Breschet was a notable anatomist who had published and translated several works on general anatomy, morphology and pathological anatomy. One of his works was devoted to the anatomy and physiology of the auditory organ and hearing in humans and vertebrates, which shows his interest in the anatomy of the senses. ${ }^{88}$ Together with his fellow anatomist Roussel de Vauzème, Breschet continued his interest in the anatomy of the sensory organs by investigating the anatomy of human and animal skin with the help of a microscope. Their article with three engraved plates was published as a separate small work in 1835: Nouvelles recherches sur la structure de la peau. ${ }^{89}$ The illustrations in these plates played an important role in the visual definition of the microscopic structure of the skin.

In their work on the skin Breschet and Roussel de Vauzème aimed to contribute to the little known structure of the skin so far with empirical observation. According to them, previous research on the skin was not accurate and lacked information on the "organic elements of the cutaneous tissue". ${ }^{90}$ Breschet explicitly reproached 'speculative' research in favour of empirical observations. So he wanted to correct the lack of knowledge by

83

84

85

86

87 Breschet, G., \& de Vauzème, A. R. (1834). Nouvelles recherches sur la structure de la peau. Annales des Sciences naturelles. Tome second. Septembre, Octobre et Décembre.

88 Breschet, G. (1833). Études anatomiques et physiologiques sur l'organe de l'ouie et sur l'audition, dans l'homme et les animaux vertébrés. Présentées à Académie royale des sciences le 27 Aout 1832. Paris: Madame Veuve Thuau.

89 Breschet, G., \& de Vauzème, A. R. (1835).

90 Ibid., p. 1: "des élémens organiques du tissue cutané". 


\section{Chapter 3}

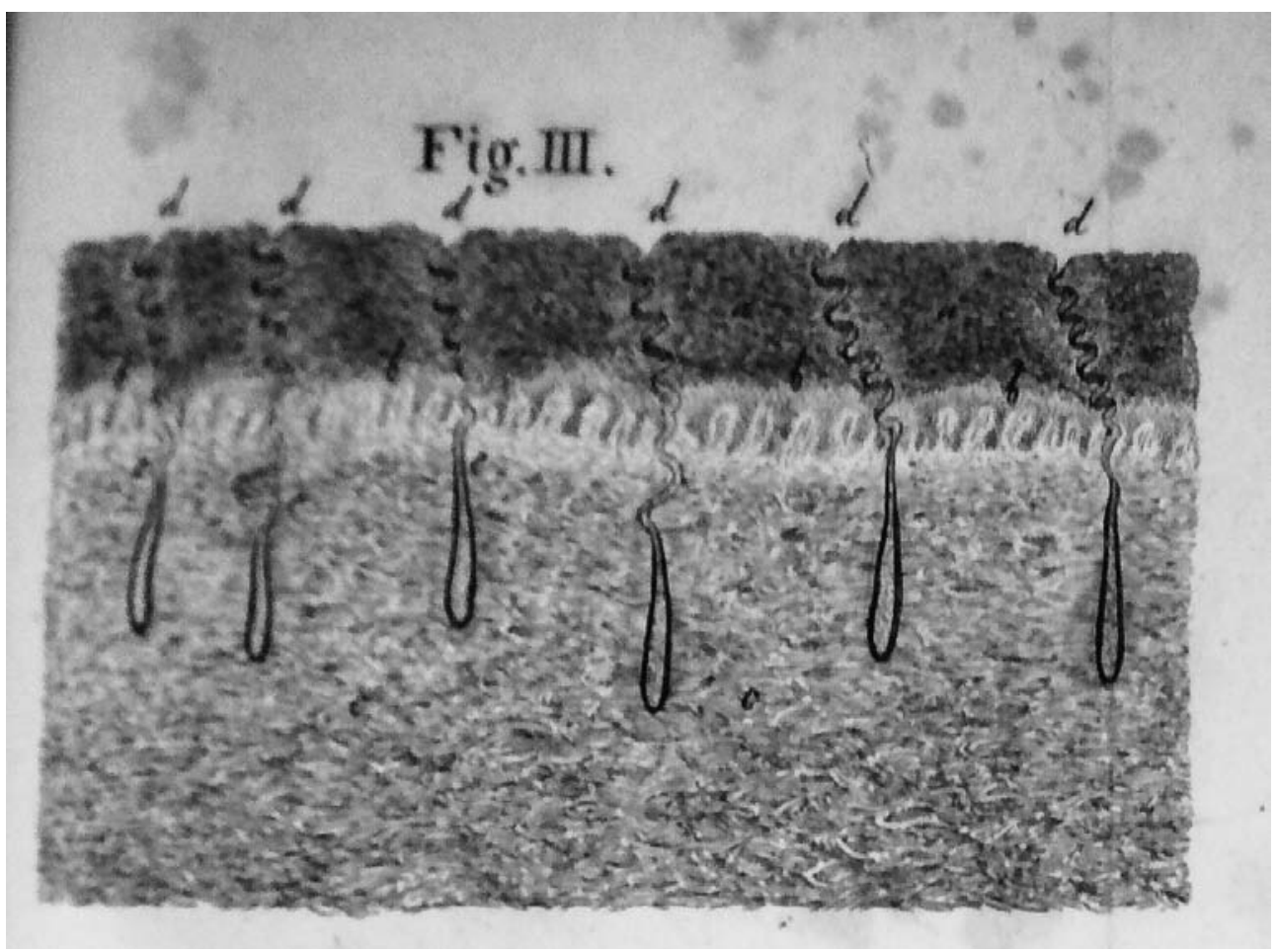

Figur 3.2 Wendt's depiction of the sweat 'Fäden' in 1834. Archiv für Anatomie, Physiologie und wissenschaftliche Medicin $(22 \mathrm{~cm})$.

repeating observations with the microscope, while being aware of the possible dangers of microscopic errors and illusions. ${ }^{91}$ He suggested that only those critiques that were based on empirical research by anatomists who were perseverant enough to pick up the scalpel and microscope themselves should be taken seriously. If such empirical research had been done earlier, we could already have known about the 'intimate composition' of the skin, argued Breschet. ${ }^{92}$ This emphasis on repeated empirical observation and the awareness of flaws in microscopy point to a more general attentiveness to intricate methodologies in the debate on microscopy at the time. ${ }^{93} \mathrm{New}$ ways of analysing the microscopic structure of the skin were in the making.

Depictions of microscopic structures were important components of the new ways of analysing skin in Breschet's work. In his research Breschet compared the structures of the human skin and the skin of a whale by discussing the different subsequent elements of their composition. ${ }^{94}$ According to Breschet, the skin consisted of six parts: Derme,

91 Ibid., p. 2.

92 Ibid., p. 2: "on serait arrive depuis long-temps à la connaissance de la composition intime de la peau".

93 For an extensive discussion of epistemological and methodological discourses in German microscopy see: Schickore, J. (2001b).

94 Breschet, G. \& de Vauzème, A. R. (1835), p. 3: "l'examen comparatif de la peau de l'homme avec celle d'une baleine franche". 


\section{Thickening skin}

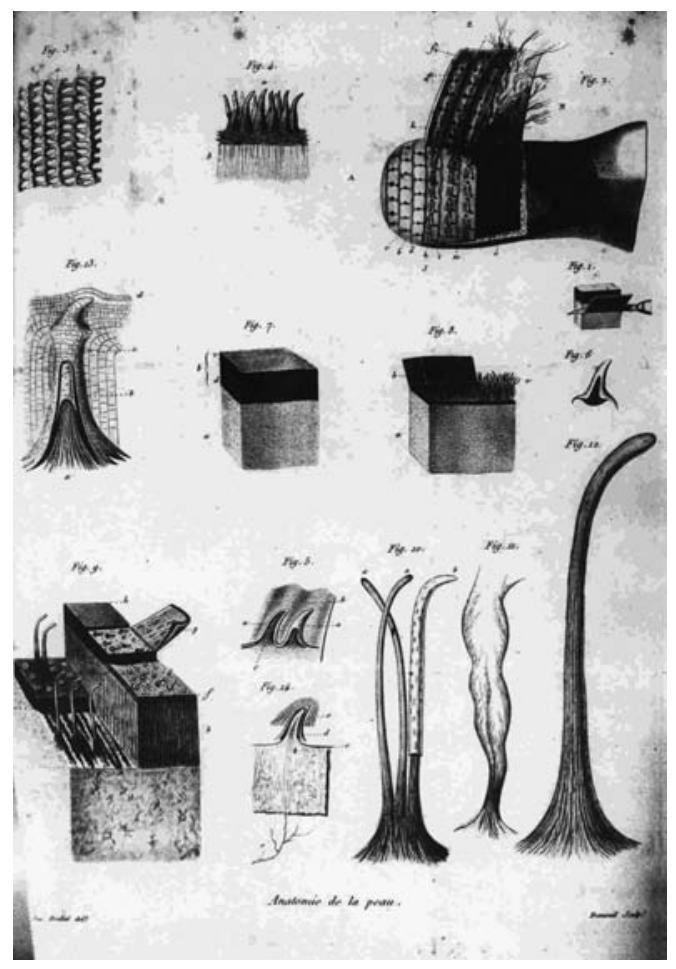

Figure 3.3 Plate 9 in Breschet \& de Vauzème's researches on the anatomy of the skin (1835) (8vo).

Papilles, Appareil diapnogène, Appareil d'inhalation, Appareil Blennogène and Appareil chromatogène. ${ }^{95}$ Each chapter of the treatise covered the anatomical preparation, a description and various animal forms for one part. Moreover, the parts were depicted on three plates, with a total of 48 figures (see example in figure 3.3). In the plates the parts of the skin are displayed in schematic black and white copper engraved figures. In his depictions Breschet gave a fairly prominent place to the sweat conducting channels. While the first plate mostly showed figures of the skin papilla, the second plate was devoted to the display of the 'internal' organs and structures composing the skin, with the sweat producing organ as one of the main components. Visually, the sweat organ was portrayed as a little hairy ball, with a spiralled tube opening on the skin surface (see figure 3.4). In his explanation of the figures Breschet described the appearance of the morphology of the sweat excreting system when seen with a strong magnifying glass and a microscope. The sweat transporting channels, for example, were displayed as seen enlarged under the microscope. Other active, functioning organs inside the skin were articulated visually as well. A visual image of the internal structure of the skin was therefore brought into being. 


\section{Chapter 3}

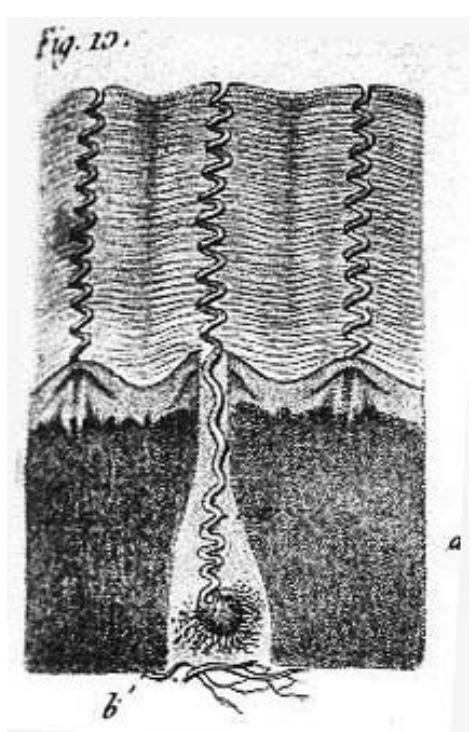

Figure 3.4 Breschet \& de Vauzème’s depiction of the sweat organ. 'Organe sudorifere.' In Nouvelles recherches sur la structure de la peau (1835).

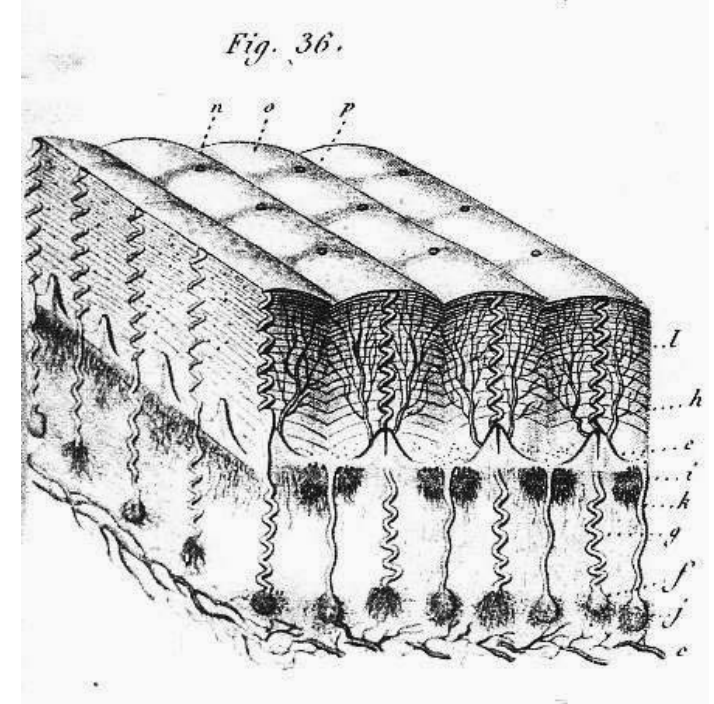

Figure 3.5 A schematic representation of the skin. In Breschet \& de Vauzème Nouvelles recherches sur la structure de la peau (1835).

However, the intimate structure of the skin did not betray its appearance very easily. Because of its complex structure the skin was extremely difficult to prepare. The dense, elastic and resistant quality of the skin made it almost impossible to study. ${ }^{96}$ Breschet described how difficult it had so far been to depict the internal structure of the skin. In a note to his explanation of the figures he wrote how analyses of the skin had so far been represented in pictures of square specimens of skin without exposing its internal structure. In his study with de Vauzème Breschet solved this problem by reverting to depictions of schematic compositions of the structures inside the skin (see figure 3.5). Just like the study of the skin part by part, Breschet depicted the separate parts or functional organs and then composed a schematic figure of the skin. Without schematisation the entire composition of the countless quantities of structures in the skin would compromise the clarity of the relationships between the different structures:

Jusqu'ici les études de la peau ont été représentées par échantillons carrés, dont l'esprit ne peut saisir les rapports. Pour éviter cet inconvénient, nous avons figure un talon entier compose d'après nature, en observant la forme et la situation respective des parties, mais sans égard pour le nombre. S'il veut fallu par exemple, offrir aux yeux la quantité précise de papilles qui se trouvent au talon, la planche entière eût été loin d'y suffire. Pour l'intelligence des rapports des objets si nombreux dans leur petitesse, nous avons été force de composer ainsi plusieurs autres figures. ${ }^{97}$ 


\section{Thickening skin}

Figure 3.5 is an example of a figure that illustrates how the skin was visually thickened in these schematic compositions of the microscopic structures inside the skin. This picture showed the "composition of a synthesized figure or Scheme of the human skin". ${ }^{98}$ Each part of the skin in this figure symbolised a different functional structure. The production of sweat for example was articulated by the sweat producing organ and its channels to the surface ending in the pores.

The anatomical investigation of the skin by Breschet resonates with the developments in medical microscopy in Paris in the 1830s. As Anne La Berge has shown, many of the leading physicians in the Paris school used the microscope for research and teaching activities. ${ }^{99}$ Although Parisian physicians did not embrace microscopy in the same way as German physicians and scientists, an active microscopy community developed in Paris in the 1830s. Breschet's use of the microscope in his investigations on skin epitomises La Berge's argument that medical microscopy developed in the context of Paris clinical medicine and pathological anatomy in the 1830s. ${ }^{100}$ Breschet preferred research in comparative anatomy, morphology, physiology and pathology to the practical clinical anatomy that is known as being typical of the Paris medical school. ${ }^{101}$ To Breschet the use of the microscope to study the anatomy of organs followed from his interest in morphology, pathology and physiology. In 1828 he had already published a paper on the microscopic structure of nerves together with François Raspail, one of the most notable physicians using chemistry and microscopy in the study of plant tissue. ${ }^{102}$ Within the context of Paris medicine Breschet thus belonged to one of the earliest generations of physicians using the microscope.

Yet the position of Breschet and his work on skin seems even more significant when considering his connection to developments in German anatomy and physiology. Breschet's work on the structure of the skin connected Parisian ways of analysing skin with German ways of analysing tissues. Whereas in Germany physiologists stressed the generative and developing nature of human structures and forms, Parisian physicians emphasised dissection and morphologies of normal and abnormal tissues. ${ }^{103}$ With his accent on the structural organisation of the skin and the comparison between anatomical forms of skin, as well as his microscopical interest in anatomy and physiology, Breschet connected both ways of analysing. He recognised that without a proper knowledge of the anatomy of the skin, insights into physiological functions of the skin would remain

98 Ibid., p. 119: "composition d'une figure synthétique ou Schema de la peau humaine".

99 La Berge, A. (1994). Medical microscopy in Paris, 1830-1855. In A. La Berge \& M. Feingold (Eds.), French medical culture in the nineteenth century (pp. 296-326). Amsterdam-Atlanta G A: Rodopi; La Berge, A. (1998). Dichotomy or integration? Medical microscopy and the Paris clinical tradition. In C. Hannaway \& A. La Berge (Eds.), Constructing Paris medicine (pp. 275-312). Amsterdam, Atlanta G.A.: Rodopi.

100 La Berge, A. (1998), p. 280.

101 Huard, P., \& Imbault-Huart, M.-J. (1975). Gilbert Breschet ou le savant polyglotte (Clermont-Ferrand, 7 juillet 1784 - Paris 10 mai 1845). Gazette Médicale Tome 82(23), 2839-2840.

102 Breschet, G., \& Raspail, F. (1828). Ricerche microscopiche sulla struttura dei nervi. Annali universali di medicina Serie 1, 46, Fascicolo 136.

103 On different forms of analysis in science, technology and medicine see: Pickstone, J. V. (2000). Ways of knowing: a new history of science, technology and medicine. Chicago: The University of Chicago Press; in particular chapter 5. 


\section{Chapter 3}

obscure. ${ }^{104}$ Moreover, his connections with German physiology were also expressed in activities. He had translated Johann Friedrich Meckel's Handbuch der menschlichen Anatomie into French in 1825 and this French translation later served as the basis for Italian and English translations. ${ }^{105}$ In 1823 he also published in the German Archiv für die Physiologie, where he already made reference to the use of the microscope in his research. ${ }^{106}$ In addition, Breschet was a member of many learned societies outside Paris: Madrid, Rome, Bologna, Vienna, Berlin, Bonn, Heidelberg, Copenhagen, London, Dublin and Philadelphia. ${ }^{107}$

It did not take long before Breschet's findings and pictures of the structures inside the skin were picked up by microanatomists working on skin in German settings. In 1835 Ernst Friedrich Gurlt (1794-1882) published a paper on comparative research of the human skin and the skin of pet animals in the Archiv für Anatomie, Physiologie und wissenschaftliche Medicin. ${ }^{108}$ Gurlt specialised in the anatomy and physiology of domesticated mammals (Haussäugethiere) and was especially interested in the excretion of sebum and sweat by the skin. He argued that only after the latest developments in anatomy and physiology had Breschet and de Vauzème finally proven the true existence of the 'sweat glands'. ${ }^{109}$ He dismissed all the work before the studies of Breschet:

\footnotetext{
Die Haut des Menschen (...) ist zwar schon von den ältern Anatomen vielfälltig untersucht worden, aber in Beziehung auf die Absonderungs-organe des Haut-Talges und des Schweisses nur mit wenig Glück. Bald nahm man Bälge, oder Drüsen für die Absonderung des Haut-Talges (der Hautschmiere) an, bald läugnete man ihr Dasein; eben so verhielt es sich mit den sogenannten Hautporen oder Schweisslöchern, die man als bestehend voraussetzte, ohne sie wirklich nachgewiesen zu haben, oder ohne Grund wegläugnete. Erst in der jüngsten Zeit ist es gelungen, über diesen Gegenstand wie über so viele andere in der Anatomie und Physiologie, mehr Licht zu verbreiten. ${ }^{110}$
}

As in Breschet's work, pictures played a pivotal role in Gurlt's argument. A total of 11 figures on two separate copper engraved plates accompanied the text (see figure 3.6 for example). In the plates Gurlt depicted and compared cross-sections of human, horse, cow, dog, swine and sheep skin. Apart from referring to his own pictures, Gurlt

104 Breschet, G., \& de Vauzème, A. R. (1835), p. 2.

105 Meckel, J. F., Breschet, G. et al. (1825). Manuel d'anatomie générale, descriptive et pathologique. Traduit de l'allemand, et augmenté par A.-J.-L. Jourdan et G. Breschet. Paris: J.B. Baillière; Meckel, J. F., Breschet, G. et al. (1826). Manuale di anatomia generale, descrittiva e patologica. Tradotto del tedesco in francese, ed aumentato da A.G.L. Jourdan e G. Breschet. Versione italiana di P. Giusto. Naples: R. Manzi; Meckel, J. F., Breschet, G. et al. (1838). Manual of descriptive and pathological anatomy. Translated from the German into French, with additions and notes, by A.J.L. Jourdan, and G. Breschet. Translated from the French, with notes, by A. S. Doane, and others. London: G. Henderson.

106 Breschet, G. (1823). Über zwei neugeborne und hirnlose wasserköpfige Kinder. Deutsches Archiv für die Physiologie, 8, 151-156.

107 Huard, P., \& Imbault-Huart, M.-J. (1975), p. 2840.

108 Gurlt, E. F. (1835). Vergleichende Untersuchungen über die Haut des Menschen und der Haus-Säugethiere, besonders in Beziehung auf die Absonderungs-Organe des Haut-Talges und des Schweisses. Archiv für Anatomie, Physiologie und wissenschaftliche Medicin, 399-418.

109 Ibid., p. 402.

110 Ibid., p. 399. 


\section{Thickening skin}

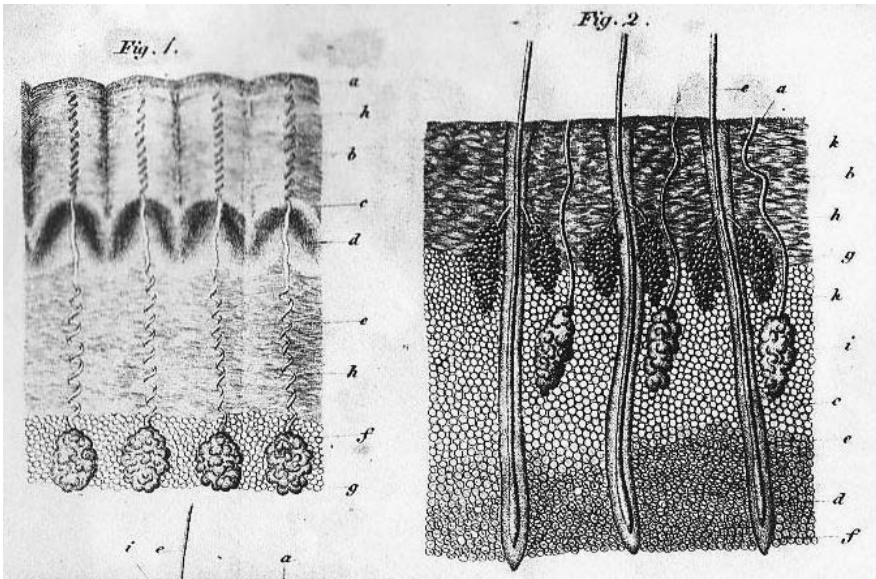

Fiigure 3.6 Cross sections of the skin of the hand and the skin of the head by Gurlt, E. F. (1835) in theArchiv für Anatomie, Physiologie und wissenschaftliche Medicin.

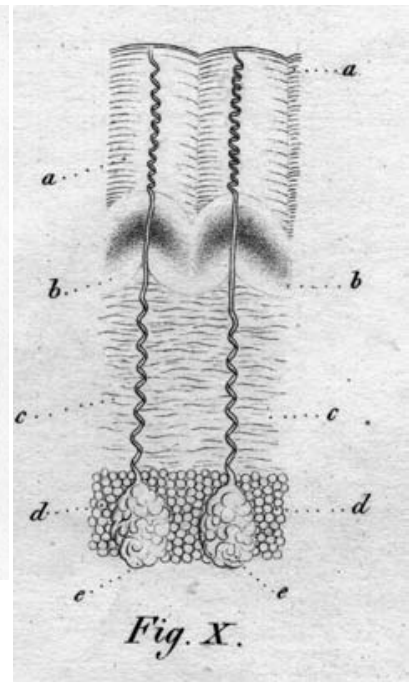

Figure 3.7 Similarity in depiction of the sweatglands. In Wagner's Erläuterungstafeln zur Physiologie und

Entwickelungsgeschichte (1839)

$(37 \mathrm{~cm})$. Museum Boerhaave, Leiden.

repeatedly mentioned Breschet's illustrations of the structures responsible for the excretion of sweat. ${ }^{111}$ When discussing the sweat glands, for example, Gurlt compared his own findings with Breschet's illustrations. He commented on the size, form and position of the sweat glands as they appeared in Breschet's figures. ${ }^{112} \mathrm{He}$ further argued that Breschet and his colleague did not properly explain the typical structure of the little balls in the sweat glands and that this structure was not well indicated in their illustrations. Taking the schematic compositions of the internal structure of the skin by Breschet as a starting point, Gurlt further articulated and redefined the specifics of the sweat glands in his article and engravings. Gurlt thereby continued the schematic way of visualising the inner structures of human (and animal) skin.

The article by Gurlt signified a shift to a vocabulary and visual articulation of sweat glands replacing the dominance of skin pores and sweat channels. In a discussion of the physiology of the skin in a German handbook in 1844 the physiologist Krause called Gurlt's images "the first faithful depictions of the actual glands". ${ }^{113}$ Remarkably enough Krause dismissed the work of Breschet and de Vouzème because of its many

111 See Gurlt, E. F. (1835): p. 405-406, and p. 415.

112 Ibid., p. 406.

113 Krause, C. F. T. (1844). Haut. In R. Wagner (Ed.), Handwörterbuch der Physiologie: mit Rücksicht auf physiologische Pathologie. Zweiter Band (pp. 108-186). Braunschweig: Vieweg, p. 127: "die ersten getreuen (...) Abbildungen der eigentlichen Drüse". 


\section{Chapter 3}

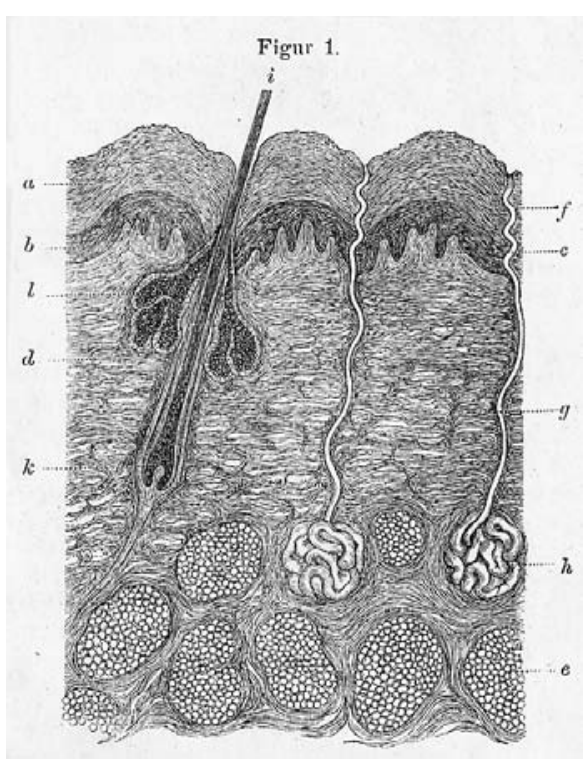

Figure 3.8 Schematic illustration of normal skin. In Neumann, I. (1869). Lehrbuch der Hautkrankheiten. $(22 \mathrm{~cm})$.

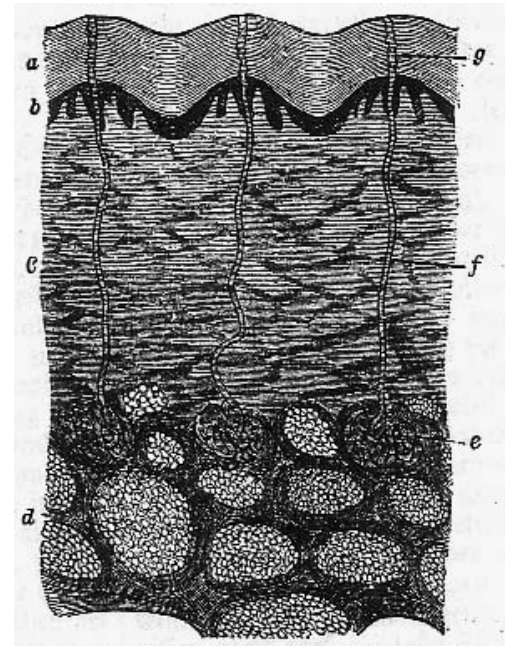

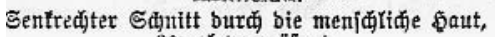
20 mal bergrö Bert.

Figure 3.9 Microscopic depiction of the skin in a German encyclopaedia 1898. Brockhaus' Konversations-Lexicon. (14th edition) $(26 \mathrm{~cm})$.

errors. ${ }^{114}$ The microscopical picture by Gurlt now represented the model image of the sweat glands. Gurlt's figure of the human sweat glands had already been directly copied by Rudolph Wagner in 1839 in his physiological plates (figure 3.7). ${ }^{115}$ Eventually, Gurlt's figure served as a template in the standardisation of a microscopical depiction of the sweat glands of the skin. Microscopical research had therefore articulated a new symbolic scheme of the anatomical composition of skin.

The microscopical depictions articulated a 'thicker' skin as it came to harbour more and more inner structures during the studies by microanatomists in the 1830s. The flat, layered and porous skin was replaced by a picture of an organ that harboured multiple active structures, including the secretion of sweat. In the context of microscopical analysis this symbolical scheme of the inner make-up of the skin was brought into existence by different anatomists, in different settings and in different sequences of figures. The common scheme of the microscopic skin as it developed during the 1830s and 1840s, however, remained a standard for many decades, in many contexts. A standardised depiction of the microscopic structure of the skin, including a hair, sebaceous glands and sweat glands, was shown in anatomical works and many works on skin diseases in the middle of the nineteenth century (see figure 3.8). ${ }^{116}$

114 Ibid., p. 115.

115 Wagner, R. (1839). Erläuterungstafeln zur Physiologie und Entwickelungsgeschichte. Leipzig: Leopold Voss.

116 Simon, G. (1848). Die Hautkrankheiten durch anatomische Untersuchungen erläutert. Berlin: G. Reimer, Taf. I, fig. 1 and 2; Kölliker, A. von (1850). Mikroskopische Anatomie oder Gewebelehre des Menschen 2.Band 1. Hälfte: Specielle 
Yet these pictures did not merely function as the articulation of new knowledge about the skin within microscopical communities and among medical specialists. Although initially the microscopical pictures were mostly shared and distributed among specialists and professionals such as dermatologists, anatomists and microscopists, microscopic pictures of the skin were eventually also printed in books for other audiences. For example, a depiction of a cross-section of human skin enlarged by the microscope appeared with the article on skin in the popular German encyclopaedia by Brockhaus of 1898 (figure 3.9). ${ }^{117}$ Comparable to the emerging standard microscopic picture of skin from the 1840s, this picture contained the sweat glands as one of the main features in the skin. The black and white engraving was similarly schematic in design and showed the opening of the sweat ducts as 'sweat-pores'. For the general public too the pores in the skin had been visually transformed and articulated as part of a structure inside a thickened skin.

The new amount of depictions in articles on the microscopic anatomy of the skin emerging in the 1830s and 1840s contrasted strongly with the lack of microscopical depictions of skin in the preceding decades. Pictures gained increasing importance in the newly established microscopical practices. At the same time the controversial nature of the debate about the skin pores made the pictures more important as evidence. In this sense the very process of microscopical research equalled the visual articulation of new structures inside the skin as proof of the existence of these structures. As historians of science Cambrosio, Jacobi and Keating have argued about the role of images in the early immunological work of Paul Ehrlich: "the establishment of new ways of representing phenomena and the constitution of the entities made responsible for those phenomena were concurrent processes". ${ }^{118}$

\section{Guiding the eye, working the pencil: on the function of pictures in microscopy}

Die Forschung und die Zeichnung gehen hand in hand. ${ }^{119}$

In this section I discuss another function of microscopical pictures besides visual articulation. Microscopical depictions of skin also functioned in a visual rhetoric of microscopical research processes. In microscopic investigations pictures were composed during the process of investigation. Several stages of the research process were thereby being fixed in pictures. This section shows how microanatomists (histologists) constructed pictures of the skin during their researches in the 1830s and 1840s and how we may

Gewebelhre von der Haut, den Muskeln, Knochen und Nerven. Leipzig: Wilhelm Engelmann Verlag, p. 1, fig. 1; Neumann, I. (1869). Lehrbuch der Hautkrankheiten. Wien: Wilhelm Braumüller, p. 10, fig. 1.

117 Haut. (1898). In Brockhaus' Konversations-Lexicon. Vierzehnte vollständig neubearbeitete Auflage. Revisierte Jubiläums-Ausgabe, Achter Band, (pp. 901-903). Leipzig: Brockhaus.

118 Cambrosio, A., Jacobi, D., \& Keating, D. (1993). Ehrlich's "Beautiful Pictures" and the controversial beginnings of immunological imagery. Isis 84, 662-699; quoted from p. 666.

119 See Purkyne, J. E. (1844), p. 435. 


\section{Chapter 3}

understand these pictures as part of a visual rhetoric in their scientific publications. Pictures did not function as empty shells that transferred ideas as communicatory tools. ${ }^{120}$ In addition to the function of visual articulation, microscopical pictures of the skin also functioned at a different level in scientific works as devices in a visual rhetoric of microscopical investigation. Processes of microscopical investigation entailed pictures for both knowledge articulation and visual persuasion. Pictures reinforced arguments by visually demonstrating the microscopical investigative process.

Instructions on the drawing of microscopic specimens were described in handbooks and manuals on microscopy. Manuals on microscopy appeared from the 1840 s onwards, especially in German. ${ }^{121}$ The methods explained in these manuals not only reflected microscopical research practice, they also typified microscopical investigations more and more in the light of possible flaws and errors. ${ }^{122}$ Moreover, the manuals contained specific subsections on the drawing of microscopic objects. Although these manuals were published some ten years after the appearance of the investigations by Breschet and Gurlt in 1835, they show remarkably well how microscopical illustrations functioned as rhetorical devices to (re)construct the investigative process. In this section I draw on both microscopical manuals and later microscopical investigations on skin. An analysis of these works demonstrates that early microscopical pictures of skin reinforced the image of the skin as a thick boundary layer by functioning together as visual demonstrations of the research process.

Drawing microscopic objects formed a crucial part of the entire process of microscopical observation. In the manuals on microscopy authors paid explicit attention to the drawing of microscopic objects by considering it in a separate section. The first German scientific manual on microscopy was written by microanatomist Julius Vogel and appeared in $1841 .{ }^{123}$ Vogel described how to use the microscope and its accessories for microscopical investigations of human and animal tissues and excretions. In the first part of the work he concentrated on clarification of the instrument and its practical use. One subsection concerned the instruments used for the drawing of microscopic objects, including Sömmerring's mirror and the Camera Lucida. These are instruments that would help the inexperienced draughtsman reproduce the image of the microscopic object on paper. The devices would project the microscopic image onto paper lying next to the microscope. The only thing to do then was to outline the image in general. Vogel emphasised that these instruments became necessary even for the experienced draughtsman when absolute accuracy was needed. ${ }^{124}$ The instruments also proved necessary for measurements of the microscopic objects. Additional technologies were

120 Gerald L'E. Turner, well-known for his work on the history of microscopes, discussed how images served in the communication of microscopic results. See: Turner, G. L. E. (1974). Microscopic communication. Journal of Microscopy 100(1), 3-20.

121 See: Schickore, J. (2001b).

122 Ibid., p. 127.

123 Vogel, J. (1841). Anleitung zum Gebrauch des Mikroskopes zur zoochemischen Analyse und zur mikroskopisch-chemische Untersuchung überhaupt. Leipzig: Leopold Voss.

124 Ibid., p. 74: "Wesentlich nothwendig aber sind sie zum Zeichnen solcher Gegestände, bei deren Nachbildung es auf a b s o l u t e Genauigkeit ankommt (...)." Emphasis in original. 
therefore closely involved in the microscopical process of observation and illustration. Other manuals gave similar attention to drawing instruments. The work on microscopy by the German botanist Hugo von Mohl, for example, included sections on different kinds of microscope, on different components, measurements, tests, illumination, observation and the drawing and preservation of microscopic objects. ${ }^{125}$ Von Mohl asserted that the experienced draughtsman would not need any special instrument for the drawing of objects. He described how the drawing devices helped to sketch the general outline of the picture. The details of the drawing however still needed to be filled out by hand. ${ }^{126}$ Instruments were used to secure a proper microscopical drawing, but additional artistic skills were still considered important.

Apart from the use of drawing instruments, microscopists emphasised the importance of drawing for the entire experience of microscopical observation. In an essay on the microscope in the Handwörterbuch der Physiologie Jan Evangelista Purkinje argued for the necessity of drawing when doing microscopical research. ${ }^{127}$ According to Purkinje, microscopic objects required visual notification as they were all 'originally visible objects'. ${ }^{128}$ The aim was to visualise and externalise the acquired subjective "inner" experiences and images of the microscopists on "outside" paper as part of the microscopical work. ${ }^{129}$ Yet, since it was not possible and not necessary to depict all the details of the subjective image, it would suffice to reduce the drawing to characteristic and essential elements. Purkinje also made an important distinction between certain types of microscopic object. In histology schematic depictions were permitted, but in the analysis of special structures of the human body faithful, true-to-life copying required the use of the Camera Lucida and other instruments:

Die Darstellungen für allgemeine Histologie müssen möglichst auf das Wesentliche sich beschränken; die sinnliche Aunschauung muß hier durchaus idealisiert werden. Nicht so ist es mit Darstellungen fûr specielle Structurlehre. Hier müssen möglichst treue Copien geliefert werden. ${ }^{130}$

Like Vogel, Purkinje recommended the use of instruments for drawing copies of the observed, although details still needed to be filled out with a free hand. In general Purkinje underlined the necessity of depictions as concise reflection of the experience of microscopical analysis of a particular object and as (schematic) articulation of the essentials of the object.

125 Mohl, H. von (1846). Mikrographie oder Anleitung zur Kenntniss und zum Gebrauche des Mikroskops. Tübingen: L.F. Fues.

126 Ibid., p. 21: "Die meisten diese Apparate projictiren das microskopische Bild auf ein neben dem Mikroskope ligendes Papier, so dass man nur mit dem Bleistifte den Umrissen des Bildes zu folgen braucht, um eine in Hinsicht auf die Proportionen richtige Skizze desselben zu erhälten. Die weitere Ausfürung der Zeichnung geschieht alsdann aus freier Hand."

127 See Purkyne, J. E. (1844), p. 433.

128 Ibid., p. 433: "ein ursprünglich sichtbarer Gegenstand (wie die mikroskopischen alle sind) zur volkommenen Verständigung meistens auch eine sichtbare anschauliche Mittheilung".

129 Ibid., p. 434: "das nun gewonnene Bild im Innern auch zur äußern Darstellung zu bringen."

130 Ibid., p. 434. 


\section{Chapter 3}

The interaction between observation and depiction in microscopical analysis was noted by several other microscopists. The Dutch physician and microscopist Pieter Harting (1812-1885) declared that drawing microscopical observations was the best means of becoming a proper observer. ${ }^{131}$ Harting argued that microscopical observation as a skill had to be acquired. Only a proper microscopical observer would be able to produce a useful depiction, according to Harting. ${ }^{132} \mathrm{He}$ stated that apart from paper and some pencils, the microscopical observer merely required a good eye, a steady hand and patience. In addition, Harting mentioned 'truthfulness' and 'clarity' as the main qualifications for a microscopical depiction. ${ }^{133}$ However, like Purkinje, Harting stressed the importance of selectivity in microscopical depiction:

\footnotetext{
...dat in slechts in zeer weinige gevallen alles, wat zich bij eene bepaalde stelling van het mikroskoop in het gezichtsveld vertoont ook in de afbeelding moet worden opgenomen, en dat, hoe schijnbaar tegenstrijdig het ook klinke, eene volkomen getrouwe afbeelding daarom nog niet altijd eene volkomen ware is. ${ }^{134}$
}

As the practices of observation and depiction were so entwined and part of one and the same research process, only the microscopical researcher himself was the right person to do the drawing. In every respect depiction was mixed with microscopic experience.

For many microscopists and authors of handbooks the entwinement of depiction with observation introduced problems as well. As early as 1829 microscopist Jacquin reflected on the difficult task of observing the object of interest under the microscope and drawing it at the same time. ${ }^{135}$ Jacquin commented that it is hard for the microscopical draughtsman to look through the microscope with one eye, while keeping the other eye on the paper with the drawing. Adaptation of the instruments, table and observer would help to prevent erroneous depiction. ${ }^{136}$ Similarly, Harting referred in his handbook to the Camera Lucida and other drawing instruments for facilitating and easing microscopical depiction. ${ }^{137}$ Vogel on the other hand pointed to the usefulness of the phenomenon of 'double vue' or 'Doppeltsehen'. ${ }^{138}$ By using this technique, the microscopist would merely require a microscope, a piece of paper and a pencil to secure his observations in an illustration. The 'double viewing' technique, however, was very strenuous on the eyes. Strict methodological guidelines on the use of drawing instruments, such as the ones published in handbooks, would help to circumvent these and other difficulties. Methodological provisions were implemented to gain control over side effects and flaws

131 Harting, P. (1848), p. 336. Harting's work was also translated into German, see: Harting, P. (1859). Das Mikroskop: Theorie, Gebrauch, Geschichte und gegenwärtiger Zustand desselben. (D. F. W. Theile, Trans.). Braunschweig: F. Vieweg und Sohn.

132 Harting, P. (1848), p. 336.

133 Ibid., p. 337: "Deze hoofdvereisten zijn: waarheid en duidelijkheid."

134 Ibid., p. 338.

135 Jacquin, J. v. (1829). For his discussion on drawing microscopic observations: pp. 157-160.

136 Ibid., pp. 157-158.

137 Harting, P. (1848), p. 344-345.

138 Vogel, J. (1841), p. 70-71. Double viewing. 


\section{Thickening skin}

in the instruments and the observer's eyes. ${ }^{139}$ The depiction of microscopic objects became methodologically defined and controlled as part and parcel of the entire research process.

By emphasising depiction as part of observation processes, microscopists created a persuasive value for microscopical illustrations. The illustrations reflected, or constructed, a kind of common observational experience that could be shared among a community of microscopic researchers. As Harting explained, good pictures formed a "common language". ${ }^{140}$ Other historians of science have also noticed comparable functions of microscopical illustrations. In her work on the microscopical investigations of botanist Matthias Schleiden, Soraya de Chadarevian discussed the production of microscopical drawings and the importance of skills. ${ }^{141}$ She describes how credibility of representations for Schleiden was ensured through the skills of the microscopist himself and through the implementation of standards. Michael Dennis on the other hand has shown how the illustrations in Robert Hooke's Micrographia represented "the process of disciplined seeing" ${ }^{142}$ Dennis argued that Hooke used his illustrations to "represent one's own sight, and re-view one's work with other members of the community". ${ }^{143}$ Moreover, Jutta Schickore argued that microscopical drawings were intended to reproduce the concrete experience of a scientific object in microscopy. ${ }^{144}$ From the mid-nineteenth century onwards microscopists considered illustrations to be important as evidence, because they reproduced a 'Naturerfahrung', not merely the singular impression of the senses. ${ }^{145}$ In general, the microscopical illustration is not therefore to be seen as a representation of a 'thing', but as (re)producing the process of microscopy. Microscopical illustration functioned as a persuasive device recalling the process of investigation.

In early microscopical illustrations of the skin a similar rhetoric of visual persuasion in microscopical research processes was at work. Consider the first plate in the work of Breschet from 1835 (see figure 3.3). Both the sequence of the figures and the configuration of the plate serve as a visual reconstruction of the microscopical research process. The first figure of the plate draws attention to the first step necessary for the microscopic study of the skin: producing a very thin slice. ${ }^{146}$ The subsequent figures then move from a macroscopic perspective towards more and more detailed views inside structures. It is as if the viewer is taken on a journey with the microscopist deeper and deeper inside the structures of the skin. In coherence with the text in the legend the reconstruction of the research process in the sequence of the figures functions as a visual argument for

139 Schickore, J. (2001b), p. 140.

140 See Harting, P. (1848) on note 2.

141 Chadarevian, S. de (1993). Instruments, illustrations, skills, and laboratories in nineteenth-century German botany. In R. G. Mazzolini (Ed.), Non-verbal communication in science prior to 1900 (pp. 529-562). Firenze: Olschki.

142 Dennis, M. A. (1989). Graphic understanding: Instruments and interpretation in Robert Hooke's Micrographia. Science in Context, 3(2), 309-364.

143 Ibid., p. 347.

144 Schickore, J. (2002). Fixierung mikroskopischer Beobachtungen: Zeichnung, Dauerpräparat, Mikrofotografie. In P. Geimer (Ed.), Ordnungen der Sichtbarkeit (pp. 285-310). Frankfurt am Main: Suhrkamp.

145 Ibid., p. 294.

146 See also 'Explication des Figures' in: Breschet, G. \& de Vauzème, A. R. (1835), p. 117. 
the presence of structures. ${ }^{147}$ The sweat gland in the second plate of Breschet's work, for example, is shown as one of the parts of the skin that was 'revealed' in the process of microscopical investigation. The illustrations therefore not only play a role as proof that a structure such as the sweat gland exists, but also that its presence must be valid since it was 'uncovered' within the process of microscopical investigation. As Harting formulated in his handbook: "Elke afbeelding moet dienen, om eene afbeelding terug te geven". ${ }^{148}$

A prominent example of visual rhetoric in relation to microscopical investigation of the skin is the work of the German physician Gustav Simon (1810-1857). Following his teacher Johannes Müller, Simon had taken up the microscopical study of diseased skin. He started his scientific training in Bonn, where he made a favourable impression on his teacher Johannes Müller. On his return to his birthplace Berlin he did his clinical studies and worked in general practice as a "physician to the poor". ${ }^{149}$ In 1844 he was invited by Müller to teach as a Privatdocent in the faculty of the Friedrich-Wilhelms University in Berlin ${ }^{150}$. By 1848 he had taken over the clinic for syphilis and skin diseases at the Charité Hospital in Berlin. The first edition of his major work on skin diseases Die Hautkrankheiten durch anatomische Untersuchungen erläutert was published that same year. ${ }^{151}$ This work contained eight copper engravings depicting Simon's findings from his microscopical investigations and was one of the first works to deal with microscopical studies of diseased skin. In his book Simon used the newly acquired insights from microscopic anatomy of the skin to see how that anatomy changed in a diseased state. ${ }^{152}$ According to Simon, his anatomical-pathological research would be of interest to physicians and students, because it discussed both the outward macroscopic changes in the skin when diseased and microscopic changes in the structures of the skin. ${ }^{153}$

This research process from a macroscopic to a microscopic level in Simon's work was reinforced by the illustrations in the plates. Simon himself stated that the illustrations served a better understanding of the textual description of changes in diseased skin. As a counterpart of the chapters in the book Die Hautkrankheiten contained one plate with figures of normal skin and six plates showing microscopical depictions of pustules, corns, warts and tumours of the skin (see figures 3.10 (plate III) and 3.11 (plate V)). All the plates were meticulously filled with figures. Together with the legend the figures in each plate functioned in a visual rhetoric that reconstructed the microscopical investigatory process. The sequence of the figures depicting the corn on a toe in plate III, for example, simulates a perspective on the corn from a macroscopic towards a microscopic level in figures 1 to 5 (figure 3.10). When viewed as a sequence, these figures move from a

147 On visual arguments see also: Zwijnenberg, R. (1999). The writings and drawings of Leonardo da Vinci: order and chaos in early modern thought. (C.A. van Eck, Trans.). Cambridge: Cambridge University Press.

148 Harting, P. (1848), p. 338.

149 Crissey, J. T. and L. C. Parish (1981), p. 124.

150 Ibid., p. 125.

151 Simon, G. (1848).

152 Ibid., see Preface, p. v-vi.

153 Ibid., p. vii. 


\section{Thickening skin}

Simon, Hauthrunkheiten.

1.
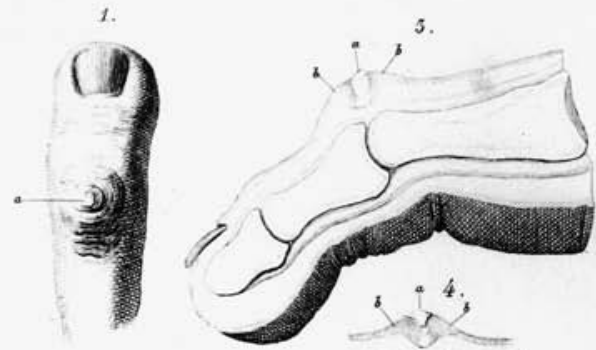

5.

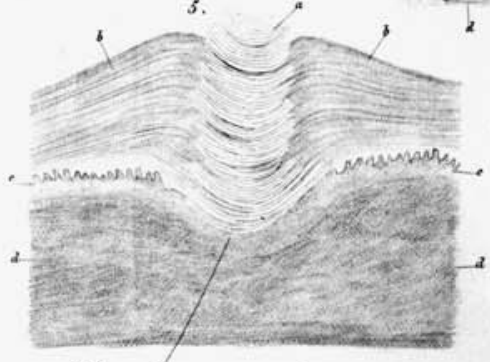

$6=$
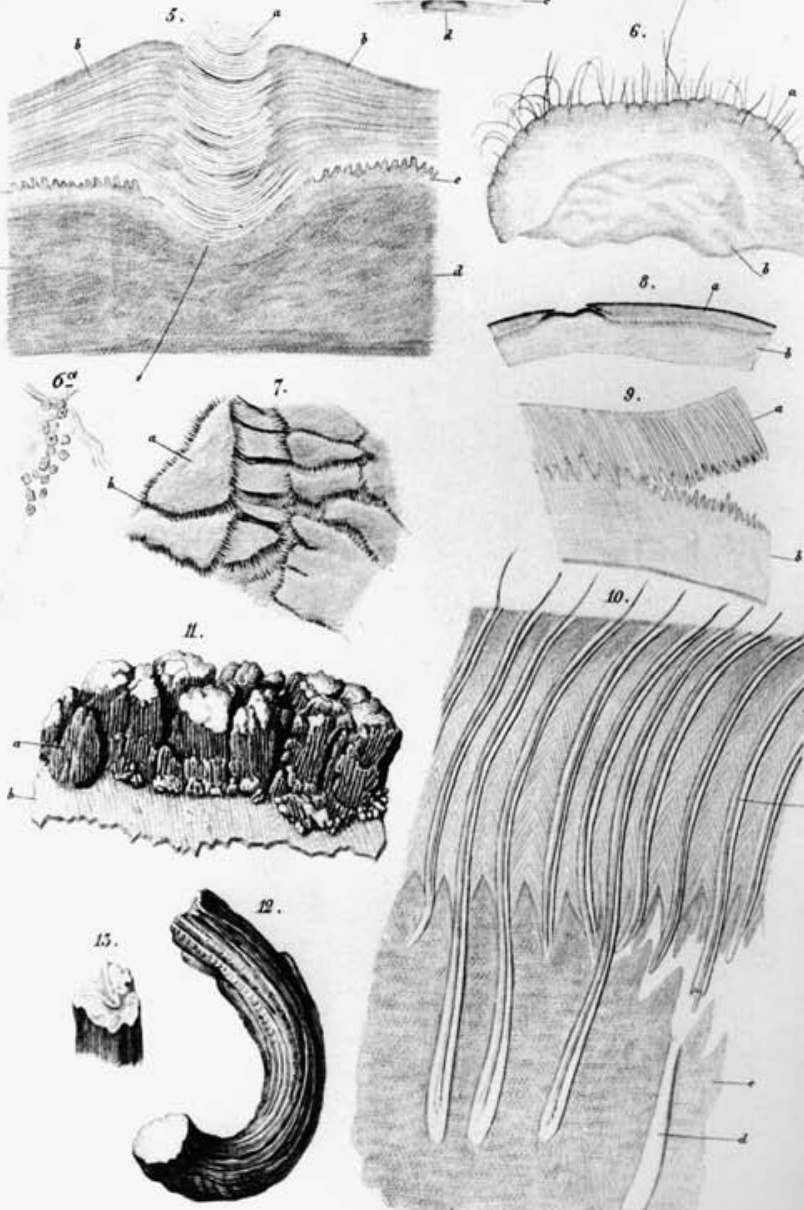

9.

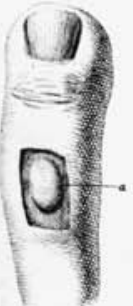

.

Iaf. III.
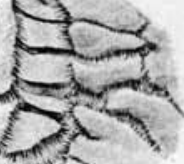

$<$
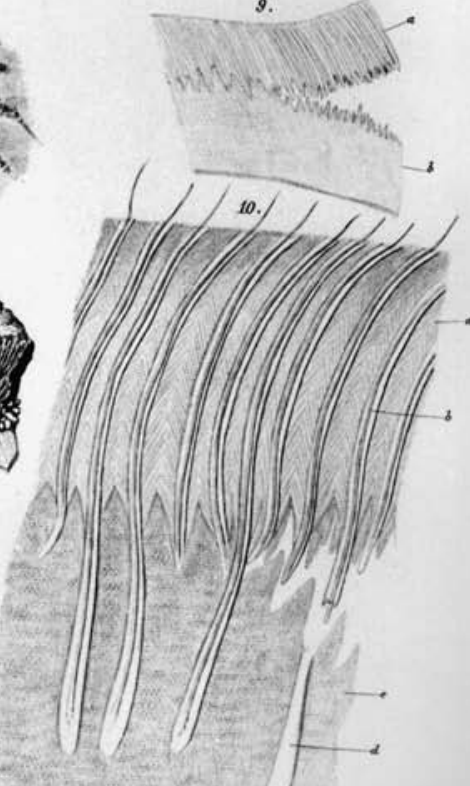

tion.

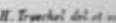

Figure 3.10 Depiction of microscopical research in Table III of Simon's 1851 Die Hautkrankheiten durch anatomische Untersuchungen erläutert. ( $2^{\text {nd }}$ edition). Library Universiteit van Amsterdam. 


\section{Chapter 3}

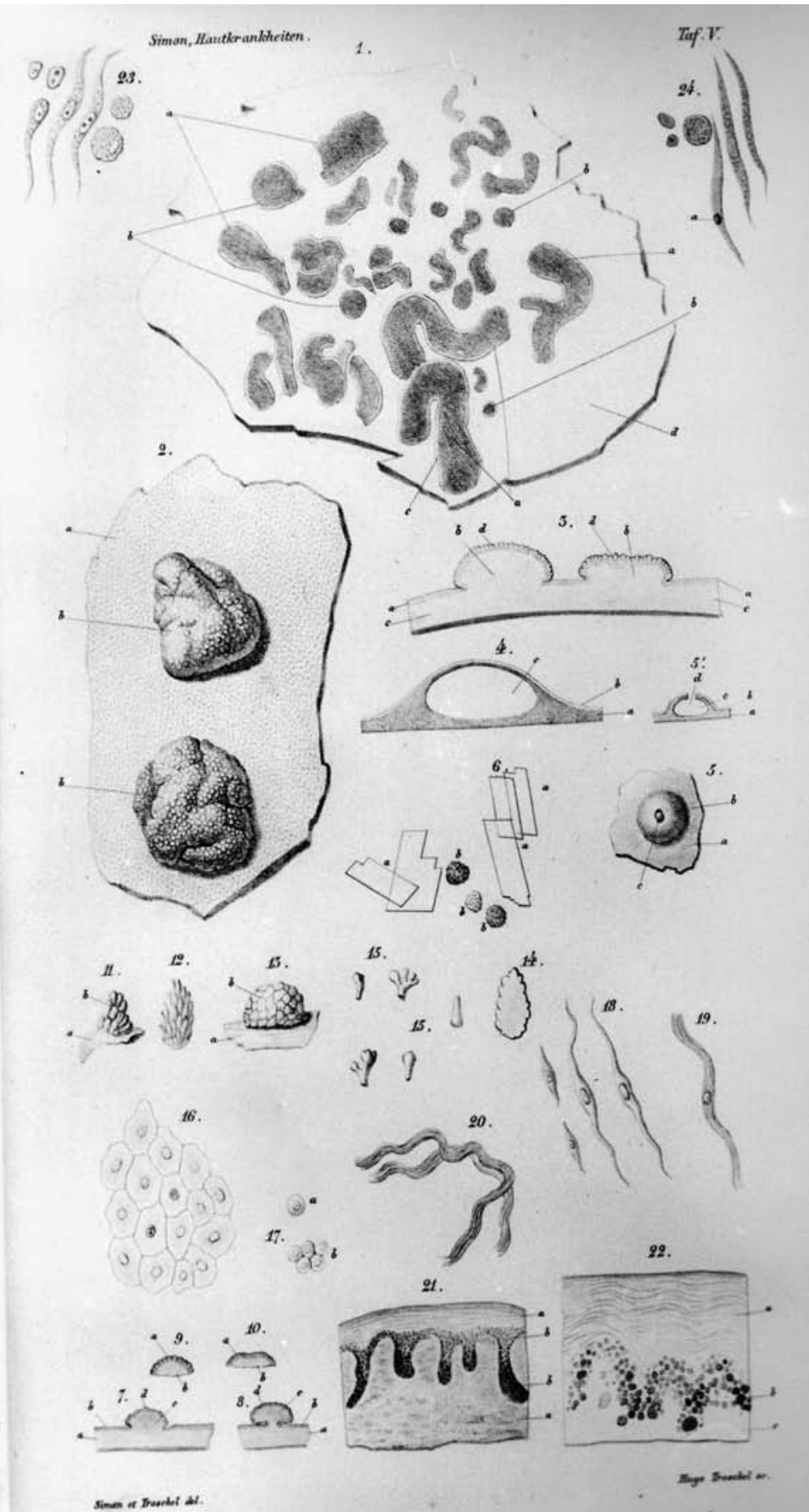

Figure 3.11 Visual dissection of a wart. Table V in Simon's 1851 Die Hautkrankheiten durch anatomische Untersuchungen erläutert. ( $2^{\text {nd }}$ edition). Library Universiteit van Amsterdam. 
general overview on a natural scale to the structures of the corn on a microscopic scale (magnified 20 times). Other figures on plates follow a similar pattern that are in keeping with Simon's aspirations to present both the macro and the micro world of diseased skin. Moreover, some figures also functioned as a visual construction of dissection processes. One sequence followed the dissection of a wart in one figure, which is followed by figures depicting the microscopic structures inside the wart individually (see figure 3.11). By visually penetrating the skin the microscope was not only involved in the reshaping of the healthy skin, but also in that of the diseased skin.

The function of microscopical illustrations as argumentative devices helped to further the idea of the skin as a closed-off organ. The persuasive ability of microscopical illustrations of skin stresses the way these illustrations both result from and reconstruct microscopical investigation processes. I have pointed out that in the illustrations themselves a new visual rhetoric is at work, which created and reinforced a new microscopically defined image of skin during the 1830s and 1840s. ${ }^{154}$ By demonstrating the very key activity of microscopy itself - observation - depictions reinforced the new thickened image of the skin.

\section{Thickening skin: from permeation to mediation}

By 1850 a new image of skin was present within a European community of anatomists and physiologists. In microscopical anatomy the thickened image of skin with the sweat glands as dominant structures became widely accepted. Typically, works on microscopic human anatomy opened with a chapter on the skin. During the 1840s and 1850s many influential textbooks on histology appeared from authors such as Friedrich Henle. ${ }^{155}$ The German anatomist Albert von Kölliker (1817-1905), a student of Johannes Müller and colleague of Rudolph Virchow, published the first main textbook of histology in $1852 .{ }^{156}$ Building on cell theory, this handbook placed the cell at the heart of the knowledge of tissues. In the precursor to this book the microscopic anatomy of the skin was depicted as a thick organ in a woodcut at the beginning of the first part. ${ }^{157}$ Von Kölliker both described and depicted the outside skin as thick layered tissues containing its own characteristic production organs. ${ }^{158}$ Microscopical depictions of skin were becoming more and more part of bodily anatomy. Von Kölliker indicated how in histology pictures had become "almost inevitably necessary" ${ }^{159}$ The microscopic image of skin was here to stay.

154 In contrast to visual culture scholars, I use the term visual rhetoric not to refer to the visualisation of a pre-existing argument (re-presentational relationship). Cf. Hill, C., \& Helmers, M. (Eds.). (2004). Defining visual rhetorics. Mahwah, NJ: Lawrence Erlbaum.

155 Henle, F. G. J. (1841). Allgemeine Anatomie-Lehre von den Mischungs- und Formbestandtheilen des menschlichen Körpers. Leipzig: Leopold Voß.

156 Kölliker, A. von (1852). Handbuch der Gewebelehre des Menschen. Leipzig: W. Engelmann.

157 Kölliker, A. von (1850), p. 1.

158 Idem.

159 Ibid., p. viii. 


\section{Chapter 3}

In the history of the body the microscopical image of skin signalled an important step in the shift towards a conception of the human body as a closed-off entity. In many medical and cultural histories of bodies the skin is discussed as an important surface in hygiene discourses. ${ }^{160}$ Yet in this chapter I have pointed to the significant role of a changing anatomical view of the skin as part of a shift in body image. The visual redefinition of the skin from a permeable layer into a mediating organ with its own internal organelles was an essential part of the emergence of the body as an internal milieu'. The important conception of the human body as an organism with an 'internal milieu' was put forward by the famous French physiologist Claude Bernard in 1857. ${ }^{161}$ His programme placed the scientific activity of experimental physiology at the heart of clinical medicine. As such, the closing of the pores and the creation of a new image of skin in the 1830s and 1840s therefore aligned with broader changes in definitions of body and disease in science and medicine.

The emergence of a microscopical image of skin afforded a new idea of bodily interiority and 'internal milieu' in medicine. As the skin was more involved with the inside, the body itself became a more closed-off entity from the outside. Because of the construction of the skin as a thick mediating boundary layer, the difference between the outside and the inside was increased. Direct communication in the form of two-way traffic was no longer possible. By visually exposing the interior of the skin, microscopists in the first half of the nineteenth century generated a different image of the skin. By the late seventeenth century the skin pores had provided an open communication between the body and its environment. The nineteenth-century concept of the skin as a closed physical boundary went hand in hand with the creation of a new conception of the interior of the body. No further easy penetration through the skin was possible. Instead, there was now an active involvement of the skin with the rest of the body. A shift in the concept of the skin therefore entailed a new attitude towards the interior of the human body.

However, discussions of the permeability of the skin did not cease during the 1850 s following the introduction of a new anatomy of the skin. Physiologists developed a special interest in the role of the skin in balances and exchanges of gases and fluids in the body from around the 1830s. ${ }^{162}$ In the subsequent decades French and German physiologists used animals to perform experiments in an attempt to discover the respiratory and perspiratory functions of the skin. The skin of the experimental animal (sheep, dogs and other mammals) was hermetically sealed off with an artificial layer to record the effects on the life span of the animal. ${ }^{163}$ One physiologist argued, for example, that the death of a rabbit with one sixth part of the skin covered related to changes in

160 See for example: Sarasin, P. (2001). Reizbare Maschinen: eine Geschichte des Körpers 1765-1914. Frankfurt am Main: Suhrkamp, pp. 264-313. In the next chapter of this book, I will discuss the importance of soap advertisements as visual materials concerning skin in sanitary movements in Britain.

161 Bernard quoted in: Corbin, A., Courtine, J.-J., \& Vigarello, G. (Eds.). (2005). Histoire du corps. 2. De la Révolution à la Grand Guerre (Vol. 2). Paris: Seuil, p. 39. See also: Bynum, W. F. (1994), p. 106.

162 Vigarello (1988), p. 170.

163 Ibid., p. 171. See also: Neumann, I. (1869), pp. 7-8. 


\section{Thickening skin}

the respiration of the skin. ${ }^{164}$ Research of this kind shows that by no means had the discussion of the mediation of the skin ended by the middle of the nineteenth century. It did, however, change in character towards discussions of the skin as a functional and also protective organ covering the body with its own inner structures. The role of the skin as an active, physiologically interesting organ for the body became a concern. This could only happen in concurrence with visual articulations of excreting organs inside the skin such as the sweat glands.

The quote by Dutch microscopist Harting at the start of this chapter on microscopical depictions as a general language played a role in two ways in this chapter. First, the microscopical pictures discussed in this chapter functioned on a scientific stage that transcends national contexts and boundaries. The German microscopist Gurlt discussed the merits of the pictures by the Frenchman Breschet. In the communication between microscopists from different (national) communities new structures were articulated visually. In the use and development of this visual language in microscopy the skin was shaped into a different structure of the human body. A second function for pictures as visual language in microscopy raised by Harting is how the understanding of microscopical pictures requires a certain amount of knowledge about microscopical research. A visual language of microscopical depiction was deployed within communities of physicians and anatomists doing microscopical observations. In the previous section I showed how microscopical depiction was part of a rhetoric of microscopical research processes. However, that rhetoric may not be accessible to every audience in the same way. This is why the visual rhetoric reinforcing the investigative process of microscopy worked specifically within medico-scientific communities of microscopists and physicians. Outside communities of specialists microscopical pictures of skin functioned more as visual articulations of skin, as in encyclopaedias for example. The complementary processes of visual articulation and visual rhetoric thus help us to understand more about the functions of visual languages for groups of experts with a shared framework. 
Chapter 3 


\section{4 \\ The incalculable blessings of clean skin}

The present is without a doubt an age of cleanliness, and we have no need of urging the command: Wash ye, and be also clean. ${ }^{1}$

Whoever wishes to preserve the skin in good order (...) must attend sedulously to the use of two things: a proper soap and a proper bath. ${ }^{2}$

Between 1840 and 1900 cleanliness of the skin became a superior, moral and healthy ideal. A clean skin came to signify more than a skin without dirt. This development of the image of clean skin as a sign of self-discipline and purity is very clear in soap advertisements of the British Pears soap company. These advertisements were aimed at selling soap, yet they also became a visual referent for the moral necessity of clean skin in British society. How this concept of a clean skin came about and how skin became a surface of both public and private cleanliness is discussed in this chapter.

In the wake of widespread cholera epidemics and growing industrialised urban communities, sanitary reformers and hygienists called for bodily cleanliness. One of them, William James Erasmus Wilson (1809-1884), British physician and specialist in skin diseases, popularised scientific knowledge of the skin to urge people to start cleaning their skin. His popular books on the skin and his appearances in the popular soap advertisements of the Pears soap company represented the emergence of a new concept of skin cleanliness. Taking the works of Erasmus Wilson as my point of departure, in this chapter I argue that a normative visual language of clean skin took shape in the sanitary movement in Britain. Clean skin and personal hygiene as a new norm for the middle and lower classes were not merely propagated by hygienists and sanitary reformers. In a visual form Pears soap advertisements also brought the new norms of moral and physical cleanliness of the skin into being. Read by a diverse audience in the streets of cities and in printed magazines of all kinds, the visual language of clean skin permeated society in Britain from the 1870s.

In this chapter I show how the scientific microscopic picture of the skin was used and transformed in the context of popularisation efforts of sanitary reform in England in the second half of the nineteenth century. Specialist knowledge of the functions and properties of the skin was presented to the public in soap advertisements and popular works on skin. In the eyes of Victorian society at large clean skin attained a visually present moral of health. In trams, on the street, and at home people were visually

1 Wilson, E. (1868). Toilet soaps. Journal of Cutaneous Medicine and Diseases of the Skin, 1, 446-448; p. 448.

2 Milton, J. L. (1879). The hygiene of the skin. London: Chatto and Windus, p. 76. 


\section{Chapter 4}

confronted with the need and want of clean skin. At first popular soap advertisements might seem far distant from that microscopic picture made by the physician interested in minute structures and sweat glands. Yet in this chapter we will see that both worlds are closely connected by the visual. The microscopical picture of the skin would meet the eye of a general public through popular works propagating the cleanliness of the skin. What happened to the skin during its travels in the public arena? How was the skin represented in the popularising literature of Erasmus Wilson between 1840 and 1900?

While medical historical literature abounds in studies and analyses concerning the emergence of public health and the British sanitary movement in the nineteenth century, the place of the skin in the quest for cleanliness has been largely overlooked by scholars. Many historians have discussed the emergence of new attention to the health of groups (as opposed to the health of individuals) and the importance of bodily cleanliness in medicine in the late eighteenth and early nineteenth centuries. ${ }^{3}$ Moreover, medical historians have shown how a greater concern to preserve a healthy and civilised, moralised society by the state marked a transition from private hygiene to public health during the eighteenth and nineteenth centuries. ${ }^{4}$ They have discussed how the state introduced large-scale sanitary measures to rid the city populations of dirt, diseases and other evils. During the nineteenth century institutions were set up in Western countries such as Great Britain, France, Germany and the United States to assess the problems of water supply, sewage and living and working conditions. Historians have pointed to the way personal cleanliness such as bathing "came about for social rather than medical reasons". ${ }^{5}$ Cleanliness became a means of uplifting the lower classes towards a moral purity. ${ }^{6}$ My analysis of skin cleanliness shows how the skin in particular became the site for controlling private cleanliness and the health of groups at the same time.

The visual history of skin cleanliness has not yet been considered in relation to the transition from private to public health. The popular work by Erasmus Wilson shows how a new conception of skin cleanliness emerged in the middle of the nineteenth century. Wilson wrote a best-selling popular treatise on the maintenance of a healthy skin, which first appeared in 1845: A practical treatise on healthy skin; with rules for the medical and domestic treatment of cutaneous diseases. ${ }^{7}$ This pocket-size volume of around

3 On public health see for example the classic work by George Rosen: Rosen, G. (1993). A history of public health (Expanded ed.). Baltimore and London: The Johns Hopkins University Press. (Original work published in 1958); and the overview by Dorothy Porter: Porter, D. (1993). Public health. In W. F. Bynum \& R. Porter (Eds.), Companion encyclopedia of the history of medicine (Vol. 2, pp. 1231-1261). London: Routledge. For a history of cleanliness see: Vigarello, G. (1988).

4 See: Wear, A. (1993). The history of personal hygiene. In W. F. Bynum \& R. Porter (Eds.), Companion encyclopedia of the history of medicine (Vol. 2, pp. 1283-1308). London: Routledge; Hannaway, C. (1981). From private hygiene to public health: A transformation in Western medicine in the eighteenth and nineteenth centuries. In T. Ogawa (Ed.), Public health: Proceedings of the 5 th international symposium on the comparative history of medicine - East and West (pp. 109-128). Tokyo: Saikon.

5 Wear, A. (1993), p. 1300.

6 On the preservation of health and the regulation of society see further: Labisch, A. (1992). Homo hygienicus: Gesundheit und Medizin in der Neuzeit. Frankfurt/Main; New York: Campus Verlag.

7 Wilson, E. (1845). A practical treatise on healthy skin; with rules for the medical and domestic treatment of cutaneous diseases. London: John Churchill. 
300 pages remained in print for 31 years. It was exemplary for the propagation of clean skin within the sanitary movement. According to Wilson, practical precautions and maintenance advice helped keep the skin healthy, thereby protecting the body from diseases. Visually, the message of keeping one's skin clean and healthy was expressed in the appealing soap advertisements from the Pears company.

In this chapter we follow the history of skin cleanliness in Britain during the lifetime of the British physician Erasmus Wilson. The first section introduces Wilson and his popular book on care for the skin. In the second section Wilson's attention to cleanliness is then placed in the context of sanitary reform. How Wilson introduced skin cleanliness as the key means to sanitary reform is discussed in the third and fourth sections. I show how Wilson underpinned skin cleanliness with scientific knowledge and how he introduced skin cleanliness as a means of asserting control over health and society. New bathing regimes and rituals had to ensure skin cleanliness. In the closing part of the chapter I turn to the crucial process of the visualisation of skin cleanliness in soap advertisements. Through Wilson the norms of skin cleanliness became a common good in the advertisements of the Pears soap company. In the last section I show how these soap advertisements acted as a normative popular visual language propagating clean skin in Britain after the 1870s.

\section{Wilson's skin}

The instructions put forth by the Board of Health for securing our defences against cholera (...) abound in recommendations having reference to the maintenance of the skin in a state of cleanliness of proper activity, of warmth; and it is only by a knowledge of the nature and functions of the skin that we can hope to succeed completely in effecting this object. ${ }^{8}$

Fear of 'Asiatic Cholera' was an important reason for the English physician Erasmus Wilson writing his popular work on care of the skin. This deadly new disease swept through Asia and eastern and western Europe in the 1830s, causing 23,000 deaths during an epidemic in England and Wales in 1832. ${ }^{9}$ In Britain the cholera epidemic set the stage for new state measures to secure public health and the gathering of statistical information on social conditions in British cities. The advice of the central Board of Health urged sanitary reform and bodily cleanliness. For the London surgeon, author on skin diseases and hygienist, Erasmus Wilson, the health of the skin was the starting point for both private hygiene and public health. His concern with the health of society in general was grounded in private cleanliness rituals. Wilson's popular work on the preservation and management of skin and hair serves as an entry into an age of cleanliness that would see a new visual language of skin. In this section we meet the man and his

Wilson, E. (1853). Healthy skin: A popular treatise on the skin and hair, their preservation \& management (4th ed.). London: John Churchill, p. viii.

9 Bynum, W. F. (1994), p. 73. 


\section{Chapter 4}

work. What were his ideas about skin and how did he present them to his readers?

William James Erasmus Wilson was a polymath and public busybody. The Londonborn Wilson established himself as a surgeon, teacher, dermatologist, hygienist and productive author. ${ }^{10}$ He studied medicine at St Bartholomew's Hospital in London and after some years of travel he was appointed as a surgeon to St Pancras infirmary in 1838. Two years later he started lecturing in anatomy at Middlesex Hospital. During his time at Middlesex he set up his own practice. Under the influence of Thomas Wakley, the prominent founder and editor of The Lancet, Wilson became interested in skin diseases. ${ }^{11}$ In the following years he published Practical and surgical anatomy (1838), The anatomist's vade mecum (1840) and Diseases of the skin (first edition 1842). ${ }^{12}$ His Diseases of the skin made Wilson well-known in the medical community. He was elected a fellow of the College of Surgeons in 1843.

Apart from his activities in medicine, Wilson acquired fame through a number of public events. The general public in Britain had become familiar with his name from the publicity surrounding a post-mortem investigation in Hounslow into the body of a soldier who had died after "regimental flogging" in $1846 .{ }^{13}$ As a result of Wilson's statements an Act of Parliament abolishing flogging in the army was implemented. Furthermore, Wilson was well-known for his philanthropy. By 1870 investments in the gas industry and the railways had made him a very wealthy man. In 1871 he famously arranged for an obelisk, known as 'Cleopatra's Needle', to be transported to its 'rightful owner', from Egypt to British soil (see figure 4.1). ${ }^{14}$ This event was followed by publications on Wilson in popular magazines such as Vanity Fair and The Graphic. He was eventually knighted by the Queen and he assumed the prestigious post of President of the Royal Society of the College of Surgeons in $1881 .{ }^{15}$

A public man, Wilson became the specialist on skin for a general audience. His status and the popularity of his best-selling work on skin turned him into a public ambassador of healthy clean skin. The first edition of his popular work on skin appeared in 1845 under the title $A$ practical treatise on healthy skin; with rules for the medical and domestic treatment of cutaneous diseases. ${ }^{16}$ The work was published under different titles and remained in print for 31 years (1845-1876). The title of the third edition was $O n$ the management of the skin as a means of promoting and preserving health, while later editions were called Healthy skin: A popular treatise on the skin and hair, their preservation

10 Gold, S. (1998). Erasmus Wilson - philanthropic polymath: an enigmatic personality. Journal of Medical Biography, 6(2), 97-104; p. 98. For an extensive biography on Erasmus Wilson and his work see: Hadley, R. M. (1959). The life and works of Sir William James Erasmus Wilson (1809-84). Medical History, 3, 215-247.

11 Crissey, J. T., \& Parish, L. C. (1981), p. 134.

12 Wilson, E. (1838). Practical and surgical anatomy. London: Longman, Orme, Brown, Green, \& Longmans; Wilson, E. (1840). The anatomist's vade mecum; a system of human anatomy. London: Churchill; Wilson, E. (1847). On diseases of the skin (2nd ed.). London: John Churchill.

13 Obituary - Sir Erasmus Wilson, F.R.C.S. (1884). The Lancet, August 16, 302-303; p. 303.

14 Hadley, R. M. (1959), pp. 238-239.

15 On Wilson's role in the Royal College of Surgeons see: Past presidents of the College. 4. Sir Erasmus Wilson. (1952). Annals of the Royal Society of Surgeons of England, 10, 66-69.

16 Wilson, E. (1845). 


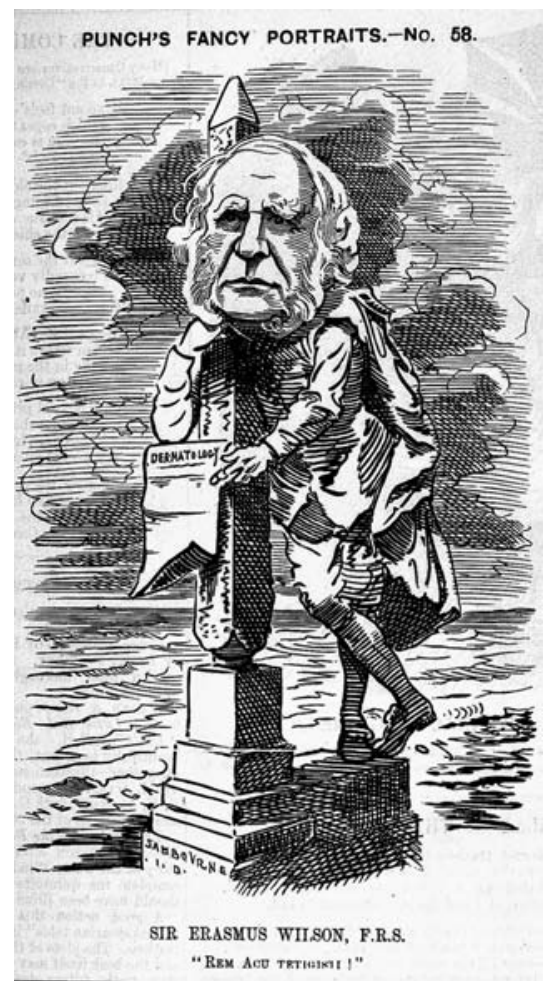

Figure 4.1 'Punch's Fancy Portraits - No. 58. Sir Erasmus Wilson FRS.' In Punch (1881), 81, p. 238. Wellcome Library, London.

and management. ${ }^{17}$ In each edition of the book Wilson provided the reader with ways of caring for the health and cleanliness of the skin.

Wilson's popular work introduced a concept of skin anchored to cleanliness and health. According to the preface to the fourth edition, the purpose of his work was twofold. On the one hand he intended to "supply a knowledge of that part of the economy of man which forms the exterior of his body and is more immediately under his own personal control - namely, the SKIN, the NAILS, and the HAIR". ${ }^{18}$ On the other Wilson wanted to suggest "reasons for the devotion of a certain amount of care and attention to its management". ${ }^{19}$ These reasons were found in the prevention of disease and the cleanliness and preservation of bodily health in general. According to Wilson, the skin was of major importance for the health of the body. Cleanliness was the key to keeping the skin in a good condition. Since the skin was crucial to the health

Wilson, E. (1849). On the management of the skin as a means of promoting and preserving health (3rd ed.). London: Churchill; Wilson, E. (1853). Healthy skin: a popular treatise on the skin and hair, their preservation and management (4th ed.). London: John Churchill; Wilson, E. (1866). Healthy skin: a popular treatise on the skin and hair, their preservation and management (7th ed.). London: J. Churchill.

18 Wilson, E. (1853), p. vii.

19 Idem. 


\section{Chapter 4}

of the entire body, the cleanliness of the skin would favourably affect the health of the body.

Healthy skin was dedicated to scientific knowledge and skin cleanliness. In 16 chapters Wilson discussed three aspects of skin: the anatomy and function of the skin, care for the skin and common diseases of the skin. ${ }^{20}$ In the first five chapters he examined the constitution and the functions of the different parts of the skin: the separate layers, the perspiratory system, the oil glands and the hair. Chapters six to nine were concerned with the management and care of the skin through clothing, diet, exercise and ablution (bathing). The last eight chapters of the book were devoted to the background and treatment of several common disorders of the skin, such as rashes, warts and corns, birthmarks and baldness. All the chapters conveyed Wilson's aims to provide knowledge and urge his readers to take care of their skin. The skin was presented as the most important link to bodily and spiritual cleanliness and purity.

Inspired by the calls for cleanliness of the Board of Health, Wilson had set himself the task of writing a book on the health of the skin for a large audience. According to Wilson, the threat of Asiatic Cholera called for a "necessity of cleanliness". ${ }^{21} \mathrm{He}$ especially stressed the importance of public baths and washhouses. He pressingly and enthusiastically described how the first public bath in London, at Euston Square in the parish of St. Pancras, was "week after week thronged with the votaries of Cleanliness and Health" ${ }^{22}$ Quoting from a report on this public bath, Wilson noted that since its opening in 1848 674,866 people had visited the establishment. ${ }^{23}$ As Wilson claimed, these visitors had "enjoyed the benefits, that is to say, have obtained the incalculable blessing of clean skins or clean linen" ${ }^{24}$ Skin cleanliness was more than an eradication of dirt. In Wilson's book skin cleanliness became a means of creating a better and healthier society.

The urge for cleanliness was grounded in current anatomical knowledge of skin. In his discussion of the anatomy and functions of the skin Wilson particularly stressed the protective properties of the skin. Since nails were considered to be part of the skin, they figured in the first chapter "On the structure and the uses of the scarf-skin". As Wilson explained in this chapter, the skin consisted of two layers: the outer, horny and insensible scarf skin and the underlying sensitive skin. In general, Wilson anatomically defined the skin as "the soft and pliant membrane which invests the whole of the external surface of the body, following its prominences, its depressions, and its curves" ${ }^{25}$ Protection was a crucial function of the skin. The scarfskin protected the sensitive skin, whereas the sensitive skin performed a protective task with respect to the deeper parts of the body. Hair was also seen as an added defence mechanism for the outer scarfskin. As an appendage of this layer of the skin, the hair was adapted to defend against external factors of different kinds: 
It [hair] is also an agent of defence against external irritants, as the heat of the sun's rays and the bites of insects; and against injuries inflicted with violence, as we see illustrated in the use of the horse's tail on the helmets of warriors. ${ }^{26}$

The skin was to keep external dangers such as dirt, insects and diseases out of the body.

Wilson's explanations of the skin anatomy reveal a strong similarity with the standard scientific image of the skin that was discussed in the previous chapter. Like the physiological image of skin that emerged in the first half of the nineteenth century, Wilson's skin had its own internal organs and functions. Every different part of the skin system fulfilled very specific tasks and performed particular actions. On the sensitive skin, Wilson referred to the wonderful 'vital constitution' of this skin layer in the second chapter of Healthy skin. ${ }^{27}$ Four different kinds of fibre, each with their own specific qualities, were equipped to do different things. A reddish set of strong and elastic fibres, for example, enjoyed a "contractile power", while another set of fibres without any strength or elasticity possessed "a faculty of independent motion". ${ }^{28}$ Together, however, these two types of fibre were able to produce the motions in the skin leading to a certain state, also called 'goose-skin', caused by the "erection of the hairs under the influence of mental emotion or physical sensation". ${ }^{29}$ Every part of the skin therefore had its own functions.

Wilson's scientific explanations were directed towards protection and cleanliness. Ultimately, the anatomical make-up of the skin served to preserve the healthy state of the body in general. The uses of the perspiratory system, for instance, were twofold. This system, consisting of "very minute cylindrical tubes" travelling through the different layers of the skin, regulated the temperature of the body and removed noxious compounds from the body. ${ }^{30}$ Wilson defined perspiration itself as "a fluid whose regularity and continuance of exhalation are not merely conductive, but absolutely necessary to health; without such regularity, the animal temperature would run riot, and substances of an injurious quality would be allowed to permeate the finest and most delicate of the tissues of the body". ${ }^{31}$ When discussing the management of the skin through clothing, Wilson actually recalled this important function of perspiration. He wrote that clothing should permit the transpiration of the skin, since transpiration was "so necessary to comfort and even to life". 32 Consequently, the scientific anatomical knowledge of the skin acted as a foundation of the rules for the management of the skin. After defining the skin as anatomically compound and functionally active and powerful, Wilson used this scientific image

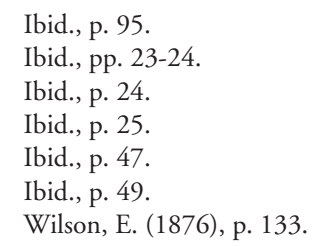




\title{
Chapter 4
}

to educate his readers on care for the skin.

Though the many editions of Healthy skin testified to a great popularity, Wilson also met with fierce critiques. His writing on skin diseases in particular were not very highly regarded in the medical community. In a review in an American medical journal, a physician reportedly wrote in 1877 :

\begin{abstract}
This is the eighth edition of a book first published thirty-one years ago; one which has undoubtedly been the means of distributing a great amount of useful information concerning the nature and care of the skin among the English-reading people. As hitherto, it treats in a popular manner of the anatomy and functions of the skin and its glandular systems, and of the influence of diet, clothing, exercise, and bathing on its health. This portion of the book (...) is wholly commendable. The remaining part, that is devoted to a treatise on the diseases of the skin, we cannot praise. It may communicate that little knowledge which is dangerous, and even that little may be wrong. For example notice what the author says about ringworm: (...) Certainly more dangerous opinions were never put forth, even in the medical literature of the daily or religious press. ${ }^{33}$
\end{abstract}

Despite its strong language, this critique by Wilson's professional colleague indicates how popular Healthy skin was at the time and to what extent it was thought to have an impact on the audience. Wilson proudly referred to the popularity and impact of Healthy skin in his preface to the seventh edition. He thanked his readers for the need for a seventh edition and referred to a quote on Healthy skin by the renowned English dramatist and writer Douglas Jerrold (1803-1857). According to Wilson, Jerrold had written a review of the book that expressed the intentions of the book so well that he decided to include it in the preface, also as reminiscence:

The work before us is a valuable contribution to the medical department of general literature. Not only will Erasmus Wilson have sufficiently established the necessity of baths and wash-houses for the labouring classes, but of THAT BATH AND THAT WASH-HOUSE WHICH THE BASIN AND THE BED-CHAMBER PLACE DAILY AT THE COMMAND OF HIS READERS. Nor will the incumbency be less obvious of those attentions to diet, to clothing, and to exercise, which he so convincingly urges as essential to the due performance of the cutaneous function. ${ }^{34}$

\section{Bodily cleanliness in an age of sanitation}

Wilson wrote his popular work on the skin at a time of sanitary reform. His aim was to present skin cleanliness as the crucial issue of sanitation. Historians have paid ample attention to the history of public health and the sanitary movement in Britain and

33 Quoted in: Crissey, J. T. and L. C. Parish (1981), p. 143-144. Original: White, J.C. (1877). 'Healthy Skin', Boston Med. Surg. J., 46: 200-201.

34 Wilson, E. (1876), p. x: Preface to the seventh edition. 
other countries. ${ }^{35}$ Indeed, the history of cleanliness has been related to changing ideas about bodily hygiene in private hygiene and public health at the turn of the nineteenth century. Yet if we want to understand the special nature of the concept of clean skin in Wilson's Britain, a short review of the role of bodily cleanliness in the transition from private hygiene to public health is needed.

Wilson dedicated Healthy skin to Edwin Chadwick (1800-1890). He commemorated Chadwick for "his strenuous and indefatigable labours in the cause of sanitary reform" ${ }^{36}$ Sir Edwin Chadwick was indeed one of the most important figures in the sanitary reform movement in Britain in the nineteenth century. As the last Secretary to Jeremy Bentham, Chadwick advocated public health as the basis of all social progress. Chadwick assumed the leadership of the early sanitary reform movement with his introduction of the New Poor Law (1834) and the Sanitary Report (1842). ${ }^{37}$ The Sanitary Report compiled an account of a broad study of the unsanitary areas in Britain. Growing numbers of inhabitants, lack of proper drainage and outbreaks of disease had created horrible living conditions in towns. Chadwick's verdict on the status of cleanliness in these towns was evident from his 1842 Sanitary Report: "the absence of civic economy in some of our towns [is such] that their conditions in respect to cleanliness is almost as bad as that of an encamped horde, or an undisciplined soldiery". ${ }^{38}$ On the basis of the outcomes of his study of the sanitary conditions of the labouring classes, Chadwick called for the foundation of a public health authority. This central body was to realise systematic changes and improvements in housing sanitation and drainage through local boards of health. Apart from clean water supplies, clean cities and clean houses, Chadwick would later also advocate personal cleanliness. The first British Public Health Act installed the General Board of Health in 1848. In the following years though England did not see any improvement and Chadwick left the scene. Others took over in attempts at professional health management, while the implementation of the Act had mixed results. In spite of the largely 'failed' Chadwickian sanitary regime following the 1848 and 1854 cholera epidemics in Britain, the concept of cleanliness had impregnated popular culture.

Physical cleanliness was related to morality. Physical purity was now defined by rules of cleanliness. For Chadwick environmental factors, such as miasmata, caused diseases of poverty, such as the much-feared cholera, fevers and infantile diarrhoea ${ }^{39}$ : "Chadwick believed these miasmata were generated by squalor, dirt, and excrement and were above

35 On public health in Britain see for example: Wohl, A. S. (1983). Endangered lives: public health in Victorian Britain. London: Dent; Hamlin, C. (1998). Public health and social justice in the age of Chadwick: Britain, 1800-1854. Cambridge: Cambridge University Press. On public health in the Netherlands see: Houwaart, E. S. (1991). De hygienisten: Artsen, staat en volksgezondheid in Nederland 1840-1890. Groningen: Historische Uitgeverij. For an overview of the history of public health in the United States see: Duffy, J. (1990). The sanitarians: a history of American public health. Urbana: University of Illinois Press. For an introduction in the history of public health in France see: Coleman, W. (1982). Death is a social disease: public health and political economy in early industrial France. Madison, Wis.; London: University of Wisconsin Press.

36 Wilson, E. (1853), title page.

37 On Edwin Chadwick see: Finer, S. E. (1952). The life and times of Sir Edwin Chadwick. London: Methuen.

38 Chadwick quoted in: Finer, S.E. (1952), p. 218-219.

39 Miasmatic theory of disease aetiology: "disease causation through non-specific contamination of the atmosphere by gaseous material given off by putrefying, decomposing organic matter”. Porter, D. (1993), p. 1243. 


\section{Chapter 4}

all associated with the putrid smells of insanitary conditions" ${ }^{40}$ To prevent disease among the poor labouring population, cleanliness was needed in every respect. Clean water was needed for cooking, drinking and washing. Moreover, moral depravity, poverty, crime and violence were rooted in physical disorder and disease. ${ }^{41}$ Public as well as private measures, such as sewerage and later also the use of disinfectants such as soap, became focal points in the crusade for good health and social reform.

The desire for purity and morality not only manifested itself in health issues. The quest for purity also emerged as an issue in art, literature and ideology in modern cultures in Europe. ${ }^{42}$ Anthropologist Mary Douglas has even placed the concern with purity at the heart of societies. ${ }^{43}$ In her seminal work Purity and danger she pointed to the way hygiene of the individual and society come together in fear of dirt as disorder. Norms of cleanliness are reinforced by rituals that create a unity in experience. Douglas showed how the distinction between clean and dirty is therefore culturally produced. She asserts that we should understand ritual as "an attempt to create and maintain a particular culture, a particular set of assumptions by which experience is controlled". ${ }^{44}$ Following Douglas, cleanliness rituals of individuals such as the washing of the skin may then culturally and also historically vary over time.

The concept of cleanliness has its own particular history. In his classic work Concepts of cleanliness sociologist and historian Georges Vigarello analyses the historical developments in the meaning and habits of cleanliness in France. ${ }^{45}$ He describes how, in the seventeenth century, cleanliness was connected with the outward appearance of clothing, not with water. In the classical period the visible appearance of white clothing was seen as a sign of cleanliness of the person. During the seventeenth century the word 'cleanliness' came to refer to distinctive attitudes and behaviour. ${ }^{46}$ Towards the end of the eighteenth century, however, cleanliness moved from the realm of the aesthetic and etiquette to the functional realm. The habit of bathing was first taken up by French nobility and later slowly penetrated society as a whole. Initially, the bath was used primarily for therapeutic ends. Vigarello notes that general bathing practices only came about with the introduction of a new kind of hygiene, which emphasised body dirt.

Vigarello therefore suggests that during the nineteenth century cleanliness moved from the visible clothing inwards to the skin. At the end of the eighteenth century physicians started to note the problems of obstructions of the pores for bodily health. The heavy layers of powders and creams that were so fashionable for the face in the seventeenth and early eighteenth centuries were now thought to obstruct the functioning of the skin. Filth, creams and sweat would accumulate in the pores and flow back into

40 Bynum, W. F. (1994), p. 72.

41 Wohl, A. S. (1983), p. 7.

42 Laarse, R. van der, Labrie, A., \& Melching, W. (1998). De hang naar zuiverheid: de cultuur van het moderne Europa. Amsterdam: Het Spinhuis.

43 Douglas, M. (1991). Purity and danger: an analysis of concepts of pollution and taboo (2nd ed.). London: Routledge. (Original work published 1966).

44 Ibid., p. 129.

45 Vigarello, G. (1988).

46 Ibid., pp. 78-79. 
the body, causing all kinds of pains, illnesses and disbalancing of blood and organs. ${ }^{47}$ After 1760 a new kind of cleanliness therefore focused on skin cleanliness and health as well. The scientifically legitimised cleanliness assumed that "to be clean meant protecting and strengthening the body". ${ }^{48}$ At the time of the early investigations of the skin pores and skin anatomy, and skin physiology, in the 1820s and 1830s hygienists stressed the importance of the perspiratory and respiratory functions of the skin. The mediatory role of the skin in both the expulsion and absorption of gases and sweat caused hygienists to emphasise the important role of skin cleanliness for bodily health. ${ }^{49}$

In histories of cleanliness the relationship between hygiene and morality is widely acknowledged. In a paper on cleanliness in America historians Richard and Claudia Bushman point to the social power of cleanliness in the nineteenth century. ${ }^{50}$ Cleanliness, moral worth and health were all intertwined norms that spread from the upper to the middle classes. Finally, there was an urge to "reform the unwashed by converting them to middle-class habits" ${ }^{51}$ Personal cleanliness became a social and cultural force:

\begin{abstract}
Cleanliness had social power because it was a moral ideal and thus as standard of judgement. Cleanliness values bore on all who wished to better their lives or felt the sting of invidious class comparisons. Dirty hands, greasy clothes, offensive odors, grime on the skin - all entered into complex judgements about the social position of the dirty person and actually about his or her moral worth. By the middle of the nineteenth century, among the middle class anyway, personal cleanliness ranked as a mark of moral superiority and dirtiness as a sign of degradation. Cleanliness indicated control, spiritual refinement, breeding; the unclean were vulgar, coarse, animalistic. ${ }^{52}$
\end{abstract}

Children especially were seen as the subject of the moral reform campaign. With regard to the history of public health in industrial France, historian Jean-Pierre Goubert referred to the development of a 'hygienic morality' in French schools by the end of the nineteenth century. ${ }^{53}$ Children were taught the habits of cleanliness, such as the washing of their hands. They learned that decency, cleanliness and tidiness earned respect and sympathy. Cleanliness was understood as both a physical and a moral ideal.

The internalisation of bodily cleanliness norms went together with a social control of cleanliness. Social historian Manuel Frey discussed this issue in his work on the emergence of bourgeois hygiene morals in German society between 1760 and $1860 .{ }^{54} \mathrm{He}$ shows how cleanliness and bathing as self-disciplining emerged in interplay with the disciplining of

49 Ibid., p. 171.

50 Bushman, R. L., \& Bushman, C. L. (1988). The early history of cleanliness. The Journal of American History, 74(4), 1213-1238.

51 Ibid., p. 1230.

52 Ibid., p. 1228.

53 Goubert, J.-P. (1989). The conquest of water: the advent of health in the industrial age (A. Wear, Trans.). Cambridge: Polity, p. 153.

54 Frey, M. (1997). Der reinliche Bürger: Entstehung und Verbreitung bürgerlicher Tugenden in Deutschland, 1760-1860. Göttingen: Vandenhoeck und Ruprecht. 


\title{
Chapter 4
}

others. The widespread distribution of water in industrial cities, for example, changed water from an individual luxury item to a general consumption good and collective agent of cleanliness. ${ }^{55}$ The 'democratic' water flowing in the cities' new sewers and baths during the nineteenth century on the one hand served the intensification of a modern body consciousness and individual control. At the same time water enforced the health and moral control over the working classes, thereby embedding cleanliness norms in society as a whole. ${ }^{56}$

Public baths and washhouses became places in European industrial cities where the social power of cleanliness was exerted. One of the goals of the sanitary movement in Britain was the establishment of public baths and washhouses for the working classes in the industrial cities. ${ }^{57}$ The first public bath opened in Liverpool in 1843. Other cities were soon to follow Liverpool's example. From 1845 public baths were introduced in London..$^{58}$ The Baths and Washhouses Act that was passed in 1846 actually preceded the Public Health Act of $1848 . .^{59}$ In the preface to his popular work on the skin Wilson repeatedly referred to the establishment and advantages of public baths:

\begin{abstract}
The first institution of this kind was established in Liverpool, in 1843, and met with so much encouragement as to attract the attention of philanthropic men in several of the manufacturing towns. The Liverpool institution possessed at that time only eight separate baths and one vapour bath, but so great was the eagerness with which they were sought by the working classes, that "as many as 220 labourers have bathed there on one Saturday". The Bishop of London - from whose speech, at the public meeting held at the Mansion House, in London, in 1844, for the purpose of promoting the establishment of public baths and wash-houses, I quoted the above statement - further illustrated the advantages of the bath, by the remark of a labourer, "that he felt he could do another week's work after he had come from the bath." ${ }^{30}$
\end{abstract}

Wilson continued that at the time of writing his book a public bath had been established in London at Goulston Square, Whitechapel, with 94 baths and 96 washing places. ${ }^{61}$ Other public baths and washhouses in London were established in Glasshouse Yard, East Smithfield, and in the parishes of St. Pancras, St. Martin's, St. Marylebone and other London districts. ${ }^{62}$ Dickens's dictionary of London from 1885 mentioned around 20 principal baths for London, including several public baths and washhouses. ${ }^{63}$ At the Paddington Public Baths, for example, facilities were available for first and second-

Ibid., p. 289.

Idem.

On similar developments in the erection of public baths to promote cleanliness in America see: Williams, M. T. (1991). Washing "the great unwashed": public baths in urban America, 1840-1920. Columbus: Ohio State University Press.

Ibid., p. 291.

Rosen, G. (1993), p. 195.

Wilson, E. (1853), p. ix.

Ibid., p. xi.

Idem.

Dickens's dictionary of London: an unconventional handbook. (1885). London: MacMillan, p. 34. 
class swimming, hot and cold showers and hot and cold baths. ${ }^{64}$ Private hygiene and the promoted personal habits of cleanliness were thus facilitated by public health services. ${ }^{65}$

Wilson's Healthy skin is more than just another example of the intertwining of morality and cleanliness. In his work he argued for skin cleanliness as the essence of both private hygiene and public health. Healthy skin set the agenda for the skin as the locus of cleanliness rituals, healthy bodies and moral control of society. If cleanliness was Wilson's faith, Healthy skin was his bible.

In his argumentation for the skin as the intersection point for morality, cleanliness and health Wilson was inspired by earlier work on hygiene. He referred to some parts of a work written by the famous German physician Christopher Hufeland (17621836). Hufeland's book Die Kunst das menschliche Leben zu verlängern (1797) had been a very popular work on the promotion of physical and moral health and as such is seen as the first work on macrobiotics. ${ }^{66}$ For Hufeland the extension of life required a certain personal lifestyle of sleeping well, exercising, being content and other regimes. Hufeland also briefly mentioned cleanliness of the skin as a means of extending life. ${ }^{67}$ He considered the skin itself as the largest cleansing agent of the human body and of major importance for the body in general. ${ }^{68}$

Wilson enlarged upon Hufeland's ideas about skin cleanliness and placed them within the scheme of sanitary reform in Britain. He appropriated Hufeland's considerations on the close relationship between skin cleanliness and general health with two particular grand aims in mind: the popularisation of new anatomical knowledge of the skin; and the propagation of skin cleanliness as a crucial public health issue. In the following sections I discuss these two aims to show how Wilson positioned skin cleanliness at centre stage of British sanitary reform.

\section{Domesticating skin: popularisation of the microscopic image}

No education can now be considered complete which does not include a certain acquaintance with medical science. The work before us is a valuable contribution to the medical department of general literature. ${ }^{69}$

64 Idem.

65 Wear, A. (1993), p. 1303.

66 Hufeland, C. W. (1797). Die Kunst das menschliche Leben zu verlängern. Jena: Akademische Buchhandlung. Wilson edited a reprint of the English translation of this book: Hufeland, C. W. (1859). The art of prolonging life (E. Wilson, Trans. 2 ed.). London: Churchill. For insights into Hufeland's work see: Pfeifer, K. (2000). Medizin der Goethezeit: Christoph Wilhelm Hufeland und die Heilkunst des 18. Jahrhunderts. Köln, Weimar, Wien: Böhlau.

67 Hufeland, C. W. (1971). Die Kunst das mensliche Leben zu verlängen (Faksimile-Ausgabe des Originals von 1797 ed.). Hamburg: Lichters, Zweiter Theil, p. 163.

68 Ibid., p. 163-164: "Die Haut ist das größte Reinigungsmittel unsers Körpers".

69 Douglas Jerrold quoted in: Wilson (1876), p. x. 


\section{Chapter 4}

In Healthy skin Wilson attempted to make the anatomical knowledge of the skin accessible to a large audience. He transformed scientific knowledge of the skin into a concept of the skin that prescribed both physical and moral health. The effects of this popularisation in Healthy skin are most visible when comparing this popular book with Wilson's medical publications. In the popularisation of the scientific image of skin Wilson sought a scientific legitimacy in his quest for skin cleanliness.

Wilson's Healthy skin was intended to bring the science of skin closer to everyday life. The book should "supply a knowledge" of the skin to its readers. ${ }^{70}$ According to Wilson, knowledge of the structure of the skin enabled the practical care of the skin:

[T]he study of the structure and phenomena of the skin, the nails, and the hair, discloses manifold illustrations of the surpassing beauty and wonderful contrivance of Nature's works and the knowledge which their contemplation bestows explains many circumstances which we are enabled to turn to practical account in the preservation of their beauty and health. ${ }^{71}$

In chapters one to five of the fourth edition in particular Wilson explained the anatomical structure of the skin and hair to his readers. With captivating titles Wilson tried to draw his audience into the anatomy of the skin. His first chapter was dedicated to the outermost layer of the skin, called the scarfskin. In his second chapter Wilson discussed the second layer of the skin and the sensitivity of the skin. The perspiratory system and "phenomena of animal temperature" were the subjects of his third chapter, while another structure, the oil glands, were part of his fourth chapter. Wilson added some sensational material to this chapter by referring to the "Parasitic animals inhabiting the oily substance". ${ }^{72}$ The attractiveness of the text was also explicitly addressed in the title of his fifth chapter on the hair: "The Hair, its structure, mode of growth, and phenomena. Changes of colour of the hair; fabulous stories". ${ }^{73}$ In Healthy skin anatomy therefore became entwined with 'fabulous' and entertaining stories.

The different titles of Wilson's popular work reveal a shift from medical interest towards management of the skin. The subsequent titles of the different editions show how the description of the work evolved from a medically inspired treatise on the skin to a popular essay on the management of the skin to promote health in general. The title of the first edition (1845), A practical treatise on healthy skin; with rules for the medical and domestic treatment of cutaneous diseases, still largely alludes to the transfer of medical knowledge. Whereas in the title of the third edition On the management of the skin as a means of promoting and preserving health (1849) a sanitary agenda is already present, later editions (from the fourth edition onwards) were eventually defined by a grand attractive title Healthy Skin: A popular treatise on the skin and hair, their preservation and management. In order to convey his message of reform - a plea for proper management of the skin - Wilson changed the title to appeal to a wide audience. The contents of the

Wilson, E. (1853), p. vii.

Idem.

Wilson, E. (1853), chapter IV.

73 Ibid., chapter V. 

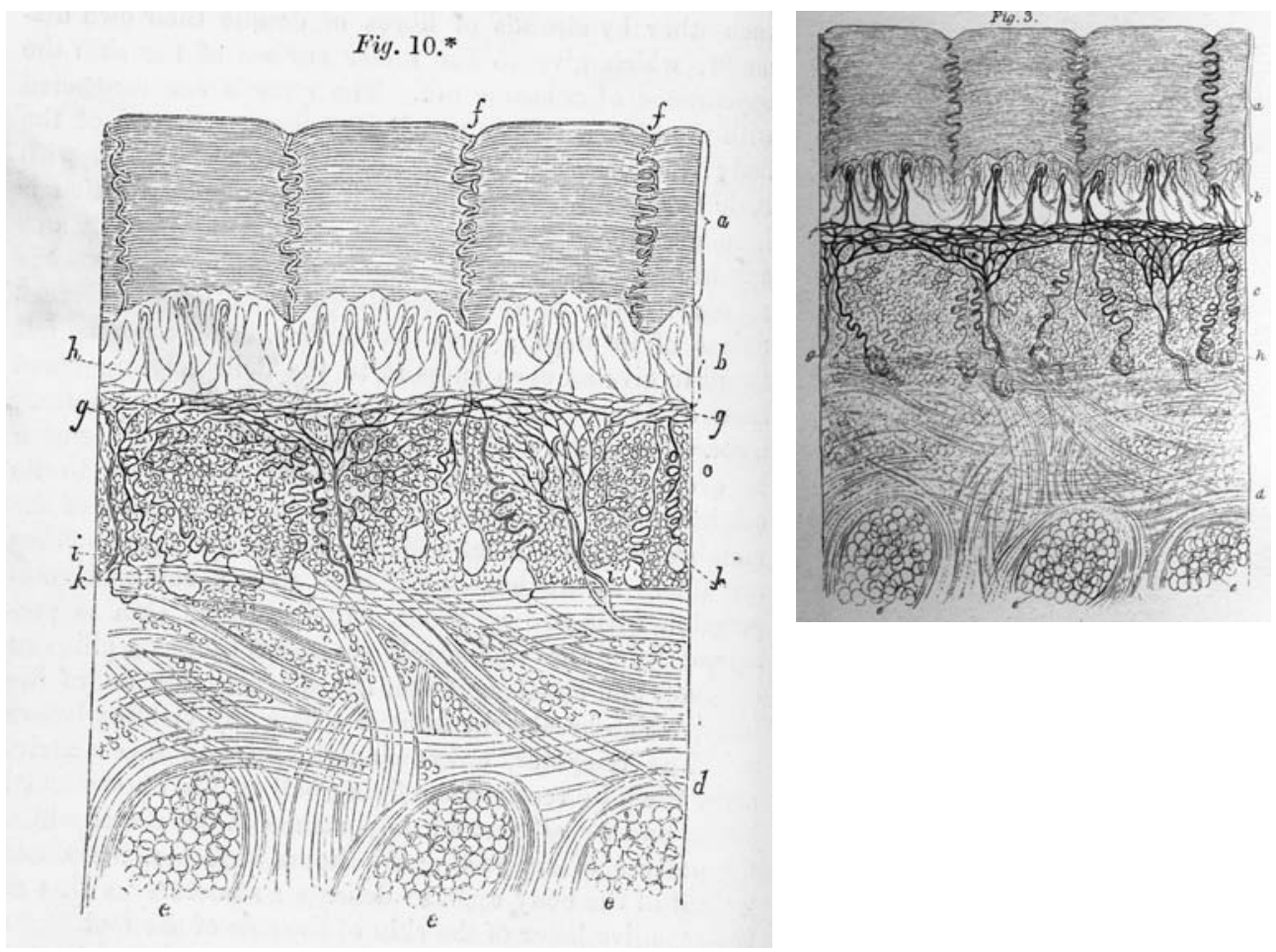

Figure 4.2 Similar illustrations in medical and popular works by Erasmus Wilson.

Left: Microscopical depiction of skin in Healthy skin: a popular treatise on the skin and hair, their preservation and management $(1853)(17 \mathrm{~cm})$. Wellcome Library, London.

Right: Miscroscopical depiction of healthy skin in Wilson's 1863 On diseases of the skin

( $5^{\text {th }}$ American edition) $(24 \mathrm{~cm})$. Museum Boerhaave, Leiden.

book, however, changed very little. In later editions some information on bathing was added, but the general set-up remained the same throughout the various editions.

Microscopical pictures are important in the process of popularisation in Healthy skin. As historians of science Roger Cooter and Stephen Pumfrey have argued, attention in the study of science in popular culture needs to turn "away from texts and towards a greater plurality of signifiers of scientific activity" ${ }^{74}$ In this chapter I seek to do this by taking pictures of skin in popular culture seriously. Later in this chapter I analyse soap advertisements that link the popular writings of Wilson to more broadly dispersed visual language of clean skin in popular culture. In this section I discuss how microscopical pictures of the skin re-emerged in Wilson's popular writings on the skin.

Travelling outside the professional community, microscopical pictures of the skin resurfaced in Healthy skin. Chapters one and two contained several microscopical illustrations, including a depiction of a section of the skin with its different layers (see

74 Cooter, R., \& Pumfrey, S. (1994). Separate spheres and public places: reflections on the history of science popularization and science in popular culture. History of Science, 32, 237-267; p. 255. 


\section{Chapter 4}

figure 4.2 left). This picture is comparable to the standard microscopical picture of the skin discussed in chapter 3. What's more, the depiction in Healthy skin is extremely similar to a microscopic picture of the skin in Wilson's medical work On diseases of the skin (figure 4.2 right). ${ }^{75}$ The illustration in Healthy Skin is a woodcut placed in the text, while the illustration in On diseases of the skin is an engraving placed separately on a plate. These pictures, although very similar, demonstrate that popularisation also involves visual transformations of knowledge.

A comparison of the medical and the popular picture demonstrates the transformation. First, the context of the pictures differed. In his early dermatological work On diseases of the skin (1863) Wilson was one of the first to discuss cutaneous medicine as a separate branch of general medicine. The book contained chapters on physiology, anatomy and pathology next to chapters on the different classes of skin diseases. Many sections in the first chapter on the anatomy and physiology of the skin are very similar to parts of Healthy skin. Yet in contrast to the description of the anatomy and physiology in Healthy skin, the discussion of the skin in the dermatological work is naturally loaded with medical terminology. For example, in $O n$ diseases of the skin Wilson wrote about the 'sudoriparous glands', while the sweat glands were called 'perspiratory glands' in Healthy skin. Moreover, in the medical work Wilson called the sensitive skin layer by its Latin medical name, without explanation. ${ }^{76}$ In Healthy skin, however, he used the term 'sensitive skin' after explaining that anatomical writers also called this layer 'derma' or 'true skin'. ${ }^{77}$ Apart from different usages of medical terms, Wilson tried to make the technical knowledge more readily accessible and enjoyable for his readers by using a style that echoed admiration for the wonderful organ of the skin in Healthy skin. By contrast, the medical text in On diseases of the skin shows a terse style of writing, mostly stating the scientific 'facts'. To his medical audience he wrote about the sweat glands that the "efferent duct and glandular tubulus of the sudiparous gland are lined by an inflection of the epidermis". ${ }^{78}$ In Healthy skin Wilson explained that "in the language of anatomical science" the tube and the sweat gland itself were involutions of the skin. ${ }^{79}$

Second, the microscopical pictures differed in content and position. The illustration in Diseases is positioned in a visual series among other illustrations. Moreover, the legend with the illustration in Healthy skin is much more explanatory than the legend in Diseases of the skin. As a result of the different printing techniques, the woodcut illustration in Healthy skin contains less detail than the engraved illustration in Diseases of the skin. For the lay audience of Healthy skin detail in the illustration was less important.

Amidst appealing examples and entertaining stories, the less detailed microscopical picture of the skin was introduced into the everyday life of the reader. When discussing the anatomy of the scarfskin, for example, Wilson brought recognisable cases to the

Compare Wilson, E. (1853), p. 24, Fig. 10 and Wilson, E. (1863). On diseases of the skin (Fifth American from the fifth and revised London ed.). Philadelphia: Blanchard and Lea, plate II, Fig. 3.

Wilson, E. (1863), p. 3.

Wilson, E. (1853), p. 22.

Wilson, E. (1863), p. 50.

Wilson, E. (1853), p. 41. 
fore: "It is the scarf-skin which the needlewoman pierces in the operation of sewing on the finger; it is the scarf-skin which the cutler shaves in order to test the sharpness of his blade". ${ }^{80}$ Apart from personal experience, Wilson also drew upon examples of imaginative actions of others, such the typical British cricketer who was saved by the defensive portion of his skin:

[T] he entire skin is preserved from the violence of contusion by being pillowed on a soft and elastic medium, the subcutaneous fat of the body, which breaks the force of a blow, by yielding before it. The cricketer, unknowingly, relies on this contrivance, when he receives the flying ball on his outstretched hand; and we all test its importance in the power which we possess of supporting, for hours together, the whole weight of the body upon so delicate a structure as that of the sensitive layer of the skin of the sole of the foot. ${ }^{81}$

Anatomical knowledge and microscopical pictures of the skin were therefore bound up with the ordinary. In Healthy skin knowledge about the skin not only resided in medical terms, but in the day-to-day experiences of bodily health and possible problems. Wilson thereby created the idea that the skin was of major importance to the body and it should therefore be managed carefully.

In Healthy skin Wilson made microscopical pictures part of his popularisation effort. The picture of the sweat gland, for example, was the same in On diseases of the skin and Healthy skin. Amidst writings about anatomical knowledge of the pores and the perspiratory system, the picture gains the form of an icon and symbol for the necessity of attention to the skin. In Wilson's popular work the amount of pores in the skin alluded to its importance for the health of the individual:

Surely such an amount of drainage as seventy-three feet in every square inch of skin $(\ldots)$ is something wonderful, and the thought naturally intrudes itself: What if this drainage were obstructed? Could we need a stronger argument for enforcing the necessity of attention for the skin ${ }^{32}$

Knowledge, pictures and a quest for cleanliness were entwined in Wilson's popular work. Like many contemporaries, Wilson tried to mobilise anatomical and physiological knowledge, as well as microscopical pictures, in the quest for moral bodily cleanliness. Effectively, the scientific image of the skin was used to legitimise Wilson's moral education of skin cleanliness as an essential issue of sanitation.

\section{Clean and healthy skin: education in the tub}

In Wilson's Healthy skin skin cleanliness was the key means to bodily health and societal

$\begin{array}{ll}80 & \text { Ibid., p. } 3 . \\ 81 & \text { Ibid., p. } 23 . \\ 82 & \text { Ibid., p. } 43 .\end{array}$ 


\section{Chapter 4}

control. Wilson presented the skin as the bodily organ directly under personal control. To follow certain regimes was to keep the skin and thereby the body healthy and clean. Yet skin cleanliness was also put forward as a form of hygiene to control others, to keep in control of bodies of the middle and working classes. In Healthy skin the idea of control was present at the level of both private hygiene and public health. Most of all, the skin was presented as the place where control should be performed. Wilson's popular book shows how the skin acquired an intriguing position as a site where both individual, private norms of cleanliness merged with public health control of groups. Here I show how Erasmus Wilson and other hygienists mobilised their popular scientific writings to place skin cleanliness at the heart of new ideals of cleanliness.

Wilson referred to the skin as a means of controlling the body. Throughout Healthy skin Wilson supplied the reader with numerous rules. Diet, clothing, exercise and washing (or ablution) had a positive influence on the health of the skin and thereby on the whole body and mind with it. The diet had to be judicious and rational so as to maintain the temperature of health, while proper clothing had to preserve this healthy state. Wilson discussed several materials, such as wool, cotton and silk, and explained what to wear and what not to wear. Although clothing served to protect the body and skin from alterations and the intense heat from both sun and atmosphere, it was not good to dress in a very tight dress, for example. Such dressing was "objectionable next to the skin; and it explains how a lady, too anxious for the protection of her person against cold, may be suffocated in her own dress". ${ }^{83}$

As another means of control over the skin Wilson mentioned bathing as a significant activity in Healthy skin. Bathing generated and preserved health. The benefits of bathing for the working classes were especially important for Wilson. Clean skin was the propagated moral. Bathing was considered the sole means of achieving skin cleanliness and a proper moral position. Wilson informed his readers over and over again about the many benefits of public baths and washhouses. They did not only function as institutions that carried "cleanliness into the humble abodes of the labouring classes" ${ }^{\text {", }}$ but they could achieve even higher goals:

[T]hey pour forth a stream of health, of happiness, of loyalty, of thoughtfulness; they elevate the moral position of those whom they succour, and the numberless benefits which they confer are not only enjoyed by those who receive, but are reflected upwards and around upon society at large. The Public Baths and Wash-houses are among the noblest of the institutions of this favoured country, as they are one of the greatest discoveries of the present age. May they meet with the support which they deserve. ${ }^{85}$

According to Wilson, baths and washhouses were so important because they acted as "schools for the moral training of the people". ${ }^{86}$ They would furthermore draw the rich 
and the poor closer together: "they are the means of drawing the rich nearer to their poorer brethren; and they enable us to fulfil (...) the Divine injunction, to "love one another"." ${ }^{87}$ Not only therefore did the bearings of skin cleanliness stretch out to uplift the morality of the labouring classes, but they would also profit the health and wellbeing of society.

The moral upgrading of the labouring classes was mediated by skin cleanliness. Apart from the maintenance of the skin in a state of proper activity and warmth, Wilson emphasised the necessity of cleanliness. In the preface to the fourth edition the need for cleanliness was put forward as a known "household truth" and "value". ${ }^{88}$ Wilson was obviously a strong advocate of washing the skin with water. Omit washing and the skin would become covered with a crust of impurities from the skin itself, from the clothes and from the atmosphere. Dust particles, soot, "poisonous gases", miasmata and "infectious vapours" would adhere to the skin and then cause problems all of kinds. ${ }^{89}$ Furthermore, as a consequence of the dirt, the pores would be obstructed, hampering perspiration. Irritation of the skin was another unwanted effect of neglecting to wash it.

Apart from Wilson, other hygienists in England also fiercely promoted skin cleanliness to morally reform the masses. In 1877 Edwin Chadwick presented a paper to the Domestic Economy Congress in Birmingham entitled 'Skin cleanliness; head to foot washing; public measures proposed for its promotion..$^{90}$ Chadwick stated that "skin cleanliness is certainly a great preservative against passing epidemics and against visitations of the most infectious and contagious diseases". ${ }^{11}$ He proposed to reduce the death rate and sickness of children in schools by "the production and maintenance of clean skins by regular head to foot ablutions with tepid water". ${ }^{92}$ Chadwick's proposals focused on "immediate and regular 'tubbing' for the population" to prevent diseases among the filthy skinned. ${ }^{93}$ Moreover, the maintenance of personal cleanliness also involved a "large public moral" and a "social element" ${ }^{94}$ Like many hygienists, Chadwick propagated cleanliness for its moral consequences:

Foreign hygienists are of accord with us on the social evils attendant to filth. Fonssagrives cites Schmalz, who says: -"Not only does the health of man depend largely upon cleanliness, but cleanliness is a condition of their activity, of their good temper, of their eternal satisfaction, and even to a certain degree, of their morality. It is in dirty villages and hovels that idleness, degradation, theft, lying, and all vices flourish. Want of cleanliness not only sullies the purity of the body, but

87 Idem.

88 Wilson, E. (1853), p. x.

89 Wilson, E. (1853), p. 157-158.

90 Chadwick, E. (1877). Skin cleanliness; head to foot washing; public measures proposed for its promotion. Journal of the Society of Arts, August 17, 883-886.

91 Chadwick, E. (1877), p. 883.

92 Idem.

93 Idem.

94 Idem. 


\section{Chapter 4}

that of the soul too." If cleanliness be next to godliness, filthiness is next to devilishness. ${ }^{95}$

Foul-skinned children especially were targeted by Chadwick's proposed sanitary measures. According to Chadwick, all schools should be provided with water supplies for proper and thorough washing facilities. The filth on the children's skin restrained them from common elementary education and Chadwick therefore concluded, " $[t]$ o be rid of dirt is a main end of education" ${ }^{96}$ Popular sanitary rhymes intended for circulation in schools further emphasised the disciplinary ritual of cleaning the skin:

There's a skin without and a skin within

A covering skin and a lining skin:

Both the skin within and the skin without,

Doubled inwards and carried completely throughout.

The palate, the nostrils, the windpipe and throat,

Are all of them lined with this inner coat,

Which through every part is ------ to extend,

Lungs, liver and bowels, from end to end.

The outside skin is a marvellous plan

For extending the dregs of the flesh of man,

While the inner extracts from the food and the air

What is needed the waste of the flesh to repair.

Good people all have a care of your skin,

Both that without and that within.

To the first, give plenty of water and soap,

To the latter little else but water we hope.

All you who thus kindly take care of your skin

And attend to its wants, without and within,

Need never of eh --- feel any fears,

And your skin may last you a hundred years. ${ }^{97}$

This rhyme represents a true moral education on skin cleanliness.

95 Idem.

96 Chadwick, E. (1877), p. 884.

97 Chadwick, E. (1877), p. 886. Lines indicate illegible words. 
At this time Chadwick had already retired from the main national public health services. He used a number of societies, such as the Society of Arts and the National Association for the Promotion of Social Science, to address the public with his ideas for sanitary reforms. Among other things he exercised profound influence on the establishment of Committees on Drill in Schools, street paving and London water supplies. ${ }^{98}$ Like these subjects, skin cleanliness remained part of his ongoing sanitary crusade against "the sanitary evil of personal filth". ${ }^{99} \mathrm{He}$ advocated national compulsory attendance at schools in a condition of absolute personal cleanliness. For Chadwick skin cleanliness was one of the "most important elementary trainings that can be given" to schoolchildren. ${ }^{100}$ In his plea for morality through cleanliness Chadwick created an image of proper clean skin: a skin cleaned with water by personal cleanliness habits, which were imprinted from early childhood. With their papers, pamphlets and other means sanitary reformers therefore educated their public on the sought-after morally charged skin cleanliness. With the dirt from the foul skin rinsed off, the outward and visible signs of indecency, poverty, "moral depravity, mendacity and the lowest vice" went down the drain with it. ${ }^{101}$ The propagated ideal was a clean, white skin that marked a visible state of health and decency.

In the sanitary reform of Victorian England skin cleanliness became a widespread moral ideal. Yet skin cleanliness required the essential technique and regime of the bath or the 'tub', as the English lovingly called it. In the preface to the seventh edition of Healthy Skin Wilson proudly stated that his fellow countrymen of his day were no longer known for their "devotion to his port-wine or to his porter" as they were to their affectionately regarded "tub". ${ }^{102}$ "Tubbing' became a necessary precondition and well organised regime for skin cleanliness. In his book Some habits and customs of the working classes (1867) Thomas Wright expressed his view on the place of cleanliness in the daily life of the working classes. ${ }^{103}$ On Saturday, after a morning's work, a visit to the public bath:

The first proceeding of the workmen upon reaching home is to get their dinner, which they eat upon Saturday and Sunday only in a leisurely manner; and after dinner the smokers charge, light, and smoke their pipes, still in a leisurely and contemplative manner unknown to them at other times. By the time they have finished their pipes it is probably two o'clock, and they then proceed to clean themselves up-that phrase being equivalent among "the great unwashed" to the society one of performing your toilet. The first part of the cleaning-up process consists in "a good wash," and it is completed by an entire change of dress. A favourite plan of cleaning-up on Saturday afternoons is - among those who live within easy reach of public baths - to take their clean suits to the bath, and

98 Finer, S.E. (1952), p. 490.

99 Chadwick, E. (1877), p. 884.

100 Ibid., p. 885.

101 Ibid., p. 883 .

102 Wilson, E. (1876), p. ix.

103 Wright, T. (1867). Some habits and customs of the working classes. London: Tinsley Brothers, Catherine Street, Strand. In the preface to the work Wright denominates himself as a working man and "a unit of the great unwashed" (p. v). 


\section{Chapter 4}

put them on after they have bathed, bringing away their working suits tied up in a bundle. Some of the higher-paid mechanics present a very different appearance when cleaned up from that which they presented an hour or two before, when we saw them sauntering out of the shop gates. ${ }^{104}$

Skin cleanliness as a moral uplifting of the working classes implied a different way of acting, of being, a better way of living, in which physical cleanliness merged with a healthy and moral state of mind. With regard to skin cleanliness, sanitarians emphasised instructions and regulations for self-management. In his book Wilson touched upon every single detail of bathing and water in chapter IX: "On the influence of ablution and bathing on the health of the skin". He called water "the most grateful, the most necessary, and the most universal, of the gifts of a wise Creator" and "one of the symbols of Christianity". ${ }^{105}$ The act of washing the skin was subject to specific rules. Indeed, there were strict do's and don'ts when it came to cleansing the body. After explaining the reasons for washing the face, Wilson continued with a full description of the correct way to wash one's face:

And now dear reader, having determined to wash your face, how will you set about it; there are many wrong ways of effecting so simple a purpose; there is but one right way; I will tell it you. Fill your basin about two-thirds full with fresh water; dip your face in the water and then your hands. Soap the hands well, and pass the soaped hands with gentle friction over the whole face. Having performed this part of the operation thoroughly, dip the face in the water a second time, and rinse it completely; you may add very much to the luxury of the latter part of the process by having a second basin ready with fresh water to perform a final rinsing. And now you will say, What are the wrong ways of washing your face? Why the wrong ways are using the towel, the sponge, or flannel, as the means of conveying and applying the soap to the face, and omitting the rinsing at the conclusion. ${ }^{106}$

A clean skin is therefore directly related to bodily acts, rituals almost in the vocabulary of Mary Douglas. Moreover, materiality is clearly involved; soap, water and towels all play a part in the prescribed and directed act of washing.

Wilson even dictated specific rules for a public bath in London. In 1865 he was asked by a city merchant who had established baths and washhouses in London to write a "code of short rules" for the public bath at Golden Lane, St. Luke's. ${ }^{107}$ The complete set of 21 rules was divided into "Essentials of bathing" and "Time for bathing". The essentials of bathing directed the bather towards the most important habits of the bathing ritual. With regard to the time of bathing, Wilson explained what time of the day was most suitable for baths varying in temperature from cold to hot. These rules acted like a script for bathing; they prescribed how to perform the technique of taking a bath. The Essentials of bathing stated:

104 Ibid., p. 188.

105 Wilson, E. (1876), pp. 159-160.

106 Ibid., pp. 162-163.

107 Ibid., pp. 195-196. 


\section{The incalculable blessings of clean skin}

1. Undress quickly.

2. Immerse the whole body and head at once.

3. Rub the skin and limbs gently with the hands while in the bath; and, in the swimming bath, swim; that you may combine moderate muscular exercise with the action of the water on the skin.

4. Try to feel when you have had enough: - some can bear immersion in water longer than others.

5. Never abuse the bath by bathing too long; your own sensations are a better test than time; you have your sensations always about you, not so your watch.

6. When you have had enough, quit the bath; and throw a large and long towel, mantle-wise, over your shoulders.

7. Dry the body leisurely, with moderate friction, beginning with the head; then take the arms and body; then the legs and feet.

8. Rough friction to the skin is never necessary; neither in the bath, nor out of it.

9. Friction has three purposes; namely, to move the circulation in the skin; to exercise the muscles; and to rub off dirt and loose skin.

10. The cleansing of the skin is very much assisted by soap; soap is tonic to the skin and very wholesome; it removes the old face of the skin and the varnish of dirt that is apt to form upon it; and it brings the atmosphere nearer to the blood and nerves.

11. Never dress until the body is perfectly dry; then the clothing should be resumed leisurely, to give the skin time to feel and breathe the air. A great authority on the bath, Mr. George Witt, F.R.S., finishes a code of rules for the bath with these memorable words: - "Finally, the bather should dress deliberately, walk away slowly, and reflect on the blessing that he has enjoyed."108

These rules present a controllable and regulated skin. They reflect the wish to change the skin cleanliness of the working classes. At the same time the instructions mirror a projection of middle-class morals of skin cleanliness. The function and texture of the skin were subject to a system of materials (soap, towel, water, etc), rules and techniques (bathing rituals) and social control. The skin had become a place where the internalised norms of the upper and middle classes met with the urges to change and control the skin cleanliness of the working classes. Chadwick even made a symbolic reference to the skin as a last stage in the "sewage" of the body, alluding to skin cleanliness as both a private bodily matter as well as an important means of societal cleanliness and health.

\section{Soap advertising and the commodification of clean skin}

Dirt, as Lord Palmerston defined it, is "matter in the wrong place." To remove this to the right place, so far as the human being is concerned, and to remove it without detriment to the health of the skin, is the function of soap. ${ }^{109}$

108 Idem.

109 Pears, F. (1859). The skin, baths, bathing, and soap. London: The author, 91, Great Russell Street, Bloomsburry, (W.C.), p. 99. 


\section{Chapter 4}

Wilson's scientifically grounded conceptions of skin cleanliness found fertile soil in the soap advertisements of the British Pears' soap company. The London-based firm of A. \& F. Pears developed into a well-known large commercial business just after the middle of the nineteenth century. While soap was little used at the start of the nineteenth century, it had grown into a commodity product par excellence by the end of the century. The consumption of soap doubled in Britain between 1841 and 1861 and doubled again by 1891. ${ }^{110}$ As a household commodity soap came to embody prevalent social values, such as "class control ('cleansing the great unwashed') and the imperial civilising mission ('washing and clothing the savage')". ${ }^{111}$ In 1843 the German chemist Justus von Liebig had proposed measuring the character of a nation by the amount of soap it used. ${ }^{112}$ The start of the mass production of soap connected the industry to skin cleanliness. This section shows how skin cleanliness was not only propagated by sanitary reformers such as Wilson, but also in the advertising campaigns of soap companies such as Pears. The advertising campaign of the Pears' soap company is particularly interesting because it made skin cleanliness into a visual subject of the emergent commodity culture.

The large-scale production of soap took off after the removal of the excise on soap in 1853. The Pears' soap company was one of the major soap producers in Britain in the second half of the nineteenth century. The process for the preparation of Pears' transparent Soap was patented as early as $1809 .{ }^{113}$ Although the history of soap making shows that various kinds of soap had been around for hundreds of years ${ }^{114}$, the commercial soap business only developed during the era of sanitary reform. In the first half of the nineteenth century the chemical composition of soap, consisting of a combination of oils or fats and alkali, was adapted in different ways. Large-scale alkali production took off in Britain after 1823.115 The iconic bar of soap became one of the first commodities produced by large companies by the end of the nineteenth century. By that time the brand name 'Pears' had penetrated Victorian society and was omnipresent both in Britain and in the United States.

In the 1850s mass production of everyday products such as soap created a culture of mass consumption. As Thomas Richards has argued, "The Great Exhibition of the Industry and all Nations" in 1851 launched a culture of commodities: "It inaugurated a way of seeing things that marked indelibly the cultural and commercial life of Victorian England and fashioned a mythology of consumerism that has endured to this day". ${ }^{116}$ In all its gloriousness the great assembly of manufactured objects at the exhibition "helped to shape the way advertisers represented commodities for the rest of the century and to

110 See note 128 in: Wohl, A. S. (1983), p. 71.

111 McClintock, A. (1998). Soft-soaping empire. Commodity racism and imperial advertising. In N. Mirzoeff (Ed.), The visual culture reader (pp. 304-316). London: Routledge, p. 304.

112 Liebig, J. von (1844). Familiar letters on chemistry, and its relation to commerce, physiology, and agriculture (J. Gardner, Trans. 2nd corr. ed.). London: Taylor and Walton.

113 Pears, F. (1859), p. v.

114 Gibbs, F. W. (1939). The history of the manufacture of soap. Annals of Science, 4, 169-190.

115 Hunt, J. A. (1999). A short history of soap. The Pharmaceutical Journal, 263(7076), 985-989.

116 Richards, T. (1990). The commodity culture of Victorian England: advertising and spectacle, 1851-1914. Stanford, CA: Stanford University Press, p. 18. 
define the most familiar imperatives of modern commodity culture". ${ }^{117}$ Shortly after the Great Exhibition in 1851 England became overwhelmed with famous men and scientists confirming the value of things in bold statements: "Every walk of life and every part of the human body now seemed to have some kind of commodity ministered to it". ${ }^{118}$ For the skin, it was the bar of soap.

For England the Pears' soap company provides a good example for the advertising of skin cleanliness. ${ }^{119}$ From 1835 Francis Pears was in charge of the Pears company, then still a small business. In his work The skin, baths, bathing, and soap Francis Pears wrote how his practical knowledge as a soap maker had driven him to write a book on the skin and soap. He wanted to educate his readers on the subject of soap, as well as on the skin. In his opinion "the indifference of the uneducated public with respect to soaps is marvellous". ${ }^{120}$ Pears was, obviously, wildly enthusiastic about the importance of the skin and its beauty: "What a wonderful thing is the skin! It is the largest and most important integument of the whole human organism!". ${ }^{121}$ With his book Pears aimed to provide the public with a "brief sketch, with a practical aim" that would help his reader to better care for their skin. ${ }^{122}$ His work reads like a song of praise to the skin and the benefits of soap. Pears relied heavily on the ideas of Wilson, given the many references to Wilson's work. ${ }^{123}$ With the entrance of his new business partner Thomas Barratt (1842-1914) in 1865 , Pears changed his soap selling strategy. With the increasing buying power of the middle classes, Pears saw his opportunity to expand and develop his soap company. Pears' soap would become a major consumer product with the help of mass-market advertising.

Soap and skin cleanliness became part of the commodity culture. While the soap industry began producing for the masses, physicians encouraged the use of soap for the skin. At the Great Exhibition of 1851 the A. \& F. Pears company was awarded a prize medal for soap. The jurors' report stated: "The jury have tried Transparent Soap, 25 years old, manufactured by A. and F. Pears, of which A. Pears was the inventor, and found it to be very good". ${ }^{124}$ It was not just the jury of the exhibition who praised Pears' transparent soap. In the preface to the work The skin, baths, bathing, and soap (1859) Francis Pears referred to "the numerous unsolicited Testimonials" he received from scientific men "who had no motive to praise except the recognition of professional excellence". ${ }^{125}$

Physicians such as Wilson emphasised the beneficial workings of soap for the skin.

117 Ibid., p. 21.

118 Ibid., p. 22.

119 For examples of soap advertising in America see: Sivulka, J. (2001). Stronger than dirt: a cultural history of advertising personal hygiene in America, 1875 to 1940. Amherst, NY: Humanity Books, pp. 84-106.

120 Pears, F. (1859), p. v.

121 Idem.

122 Idem.

123 Ibid. See for example p. 7 for references to Wilson's work.

124 Quote from the juror's report from the Great Exhibition of the Industry of all Nations in: Pears, F. (1859), page in back of the book.

125 Pears, F. (1859), p. v. 


\section{Chapter 4}

In Healthy skin Wilson referred to soap as an "indispensable aid" for washing, since "in no other way can the unctuous substance of the surface of the skin and the dirt which adheres to it be thoroughly removed" ${ }^{126}$ He reasoned that the alkali of the soap dissolved with the oily fluid of the skin, and removed the dirt with it, so that "every washing of the skin with soap removes the old face of the scarf-skin, and leaves a new one". ${ }^{127}$ In an article on toilet soaps in the Journal of Cutaneous Medicine Wilson advocated the necessity of soap for the skin. ${ }^{128} \mathrm{He}$ provided a meaningful account to praise the importance of soap:

\footnotetext{
We once knew a beautiful woman, with a nice complexion, who had never washed her face with soap all her life through; her means of polishing were, a smear of grease, e.g. cold cream, then a wipe, and then a lick with rose-water. Of course we did not care to look too closely nor to approach too closely such an avowal; and we have met in the world with persons so unfortunate as to be unable to bear soap to their skin at all. We pity both; for soap is the food for the skin. Soap is to the skin what wine is to the stomach, a generous stimulant; and a solvent to boot of the surface which holds the dirt. It not only removes the dirt, but the layer which carries the dirt, and it promotes the displacement of the old cuticle to make for the new, to increase the activity of change in the skin; it is the essence of reproduction, because it creates the want, the law of living organisation. ${ }^{129}$
}

In the moral crusade for cleanliness soap provided the answer. To control and manage the clean skin soap proved an indispensable artefact. Wilson's representation of soap in the above-mentioned article shows how all the aspects of cleanliness work together to constitute a specific meaning of the skin: the agential anatomy of the skin needs to be controlled and managed with soap in the personal cleanliness ritual of washing, which leads to a higher moral state.

In his article on soap Wilson expressed a very positive view of Pears' transparent soap. He mentioned the variety and choice of soaps available since the removal of the excise on soap. In his comments on the different kinds of soaps Wilson articulated his love for the magic substance. Carrick's elderflower soap, for example, was "so sweet, so agreeable, so wholesome" and an "old friend". ${ }^{130}$ His assessment of Pears' transparent soap was also very positive:

Turn we to toilet soaps, and there we find a name engraven on the memory of the oldest inhabitant, Pears - Pears' transparent soap, an article of the nicest and most careful manufacture, and scentless or scented, one of the most refreshing and agreeable of balms to the skin. ${ }^{131}$

It was only a few years later that this statement about Pears' soap was about to start a

126 Wilson, E. (1853), p. 160.

127 Ibid., p. 10.

128 Wilson, E. (1868).

129 Wilson, E. (1868), pp. 446.

130 Ibid., p. 447.

131 Idem. 
whole new life in a different, public context. At the end of the nineteenth century the statement on Pears' soap by Wilson had turned into a slogan that appeared in magazines, on posters and different paraphernalia. A visual array of symbols of skin cleanliness emerged in the Pears soap advertising campaign. Indeed, the displacement and travel of Wilson's praise of Pears soap into advertising not only shows the popularisation of scientific knowledge of skin, but also the visualisation process that accompanied skin cleanliness as a moral principle for the masses.

Skin cleanliness became part of mass-media advertising in the Pears campaign after 1865. A resourceful man with talented insights into publicity, Thomas Barratt completely changed the marketing and distribution system for Pears. ${ }^{132}$ With his new advertising campaigns he started a new way of advertising and many commercial advertising agencies later adopted his methods. One of Barratt's famous actions involved the distribution and circulation in Britain of coins imprinted with the name 'Pears'. Barratt also used the authority of prominent skin specialists, chemists and doctors in the Pears campaign. Among these men was Erasmus Wilson. As a recognised and wellknown public 'specialist on the skin' ${ }^{\prime 33}$, Wilson was the perfect candidate to endorse Pears' transparent soap.

As a member of 'The special commission' of witnesses, Wilson himself appeared in an engraved advertisement for Pears soap in the 1880s (see figure 4.3). ${ }^{134}$ In the ad three specialist judges gather around a bar of Pears' soap. The three eminent skin specialists appear to judge the soap as if it were a experiment or patient. The sheet at the back of the picture comprised a list of men and women who testified in favour of the soap. As such, the image seems to find its drive in the display of the greatest good in a court: the truth. Several objects in the lower part of the advertisement further enhanced the power of science, medicine, knowledge and truth at work. Books and a certificate were to convince the audience of the 'matter of factness' of the goodness of Pears' soap. One book on the far right is of particular interest to us. The back of the book reads: On the skin - Erasmus Wilson, probably a reference to Healthy skin. In a way the scientific image had found its way to the public through the soap ad. In a visual spectacle of the power of knowledge and truth a visual relationship was established between the skin science of books and the magic powers of soap. The moral ideal of skin cleanliness thus gained a visual element in the popular arena.

Yet the visualisation of skin cleanliness in Pears advertisements also entailed transformations of knowledge. One exemplary transformation was the use of a text by Wilson in an advertisement as a slogan. Figure 4.4 shows a Pears' soap advertisement containing a statement by Wilson as "a most Eminent Authority on the skin" (see Figure 4.4). This quote is reproduced from Wilson's article on soap in the Journal of Cutaneous Medicine. In the advertisement the quote refers to Pears soap as a proper means for acquiring "a bright, clear complexion, and a soft skin". In the new context

132 Dempsey, M., \& Pears A. and F. Limited. (1978). Bubbles: early advertising art from A. \& F. Pears Ltd. London: Fontana, p. 3.

133 Wilson also wrote several articles on the skin in medical dictionaries, see: Hadley, R. M. (1959), p. 245.

134 Exact date of advertisement is unknown. 


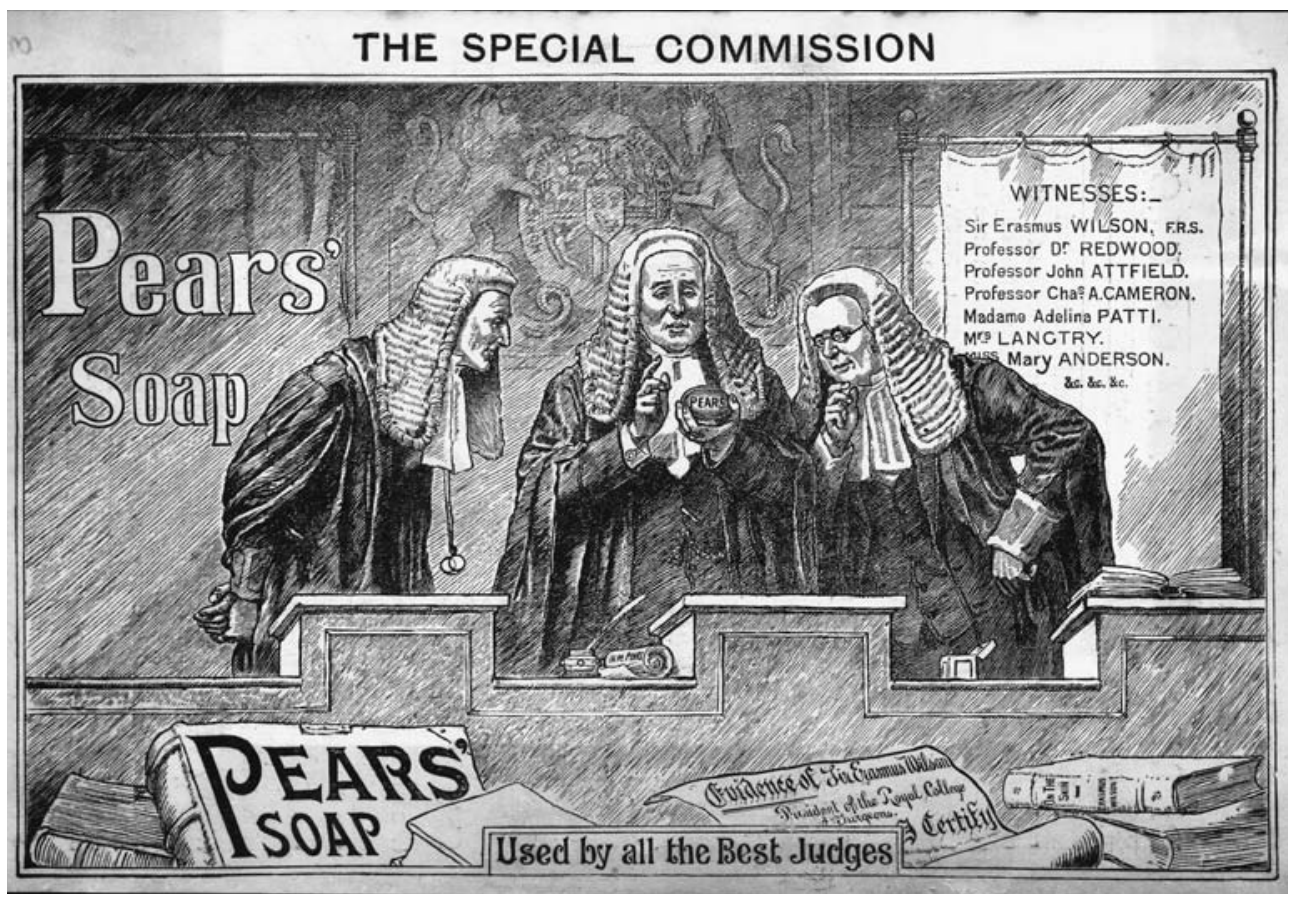

Figure 4.3 Advertisement for Pears' soap featuring Erasmus Wilson. Exact date unknown. Wellcome Library, London.

of the advertisement the quote changed. Wilson's quote was therefore transformed into a guiding testimony for the public. Another, quite striking aspect of the quote is the sentence "The use of a good Soap is certainly calculated to preserve the Skin in health, to maintain its complexion and tone, to prevent its falling into wrinkles". This sentence was not part of the original publication. The words Pears and Soap are written in capitals in the ad, not in the original quote in the medical journal. The transformation is complete. In the article the quote was only one of the soaps to be discussed in a positive way. However, in the Pears advertisement the quote signifies an authoritative statement about the quality of Pears' soap by an expert on the skin. It now seemed as though Wilson had put his reputation on the line for the Pears' soap company. Skin cleanliness, scientific knowledge of the skin and Erasmus Wilson were commercialised in the Pears advertisements.

Wilson's commercial involvement with Pears was a regulated business. Wilson himself was aware of his role in the advertisements, at least at the early stage of the advertising campaign. A letter, probably written by Wilson's business representative, provides some insights into Wilson's relationship with Pears. The letter addressed Mister Henry Hancock of the National Club in Whitehall and is dated the $12^{\text {th }}$ of June 1878 , London. In the letter, the author denied a direct partnership between Wilson and Pears 


\section{Good Complexion! AND Nice Hands!}

$\mathrm{N}^{\circ}$

OTHING adds so much to personal attractions as a bright, clear complexion, and a soft skin. Without them the handsomest and most regular features are but coldly impressive, whilst with them the plainest become attractive; and yet there is no advantage so easily secured. The regular use of a properly prepared Soap is one of the chief means; but the Public have not the requisite knowledge of the manufacture of Soap to guide them to a proper selection, so a pretty box, a pretty colour, or an agreeable perfume too frequently outweighs the more important consideration, viz. : the Composition of the Soap itself, and thus many a good complexion is spoiled which would be enhanced by proper care.

\section{Professor Sir Erasmus Wilson, F.R.\$.,}

Writes in the Journal. of Cutaneous Medicine :-

"TTHE use of a good Soap is certainly calculated to preserve the Skin in

L "health, to maintain its complexion and tone, and prevent its falling

"into. wrinkles. PEARS is a name engraven on the memory of the

" oldest inhabitant; and PEARS' Transparent SOAP is an article of the

"nicest and most careful manufacture, and one of the most refreshing

" and agreeable of balms for the Skin."

70 persons whose skin is delicate or sensitive to changes in the weather, winter or summer, PEARS' TRANSPARENT SOAP is invaluable, as, on account of its emollient, non-irritant character, Redness, Roughness and Chapping are prevented, and a clear appearance and soft velvety condition maintained, and a good, healthful and attractive complexion ensured. Its agreeable and lasting perfume, beautiful appearance, and soothing properties, commend it as the greatest luxury and most elegant adjunct to the toilet.

\section{Testimonial from \\ Madame Adelina Patti.}

"I HAVE found PEARS' SOAP matchless for the Hands and Complexion."

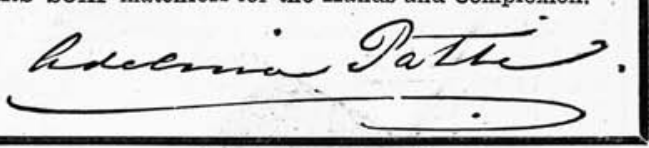

PEARS' ( TABLETS \& BALLS:

Transparent $\{$ 1s. each. Larger Sizes, 1s. 6d. and 2s. 6d.

SOAP.

(The 2s. 6d. Tablet is perfumed with Otto of Roses:)

A smaller Tablet (unscented) is sold at $6 \mathrm{~d}$.

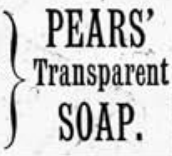

EARS' SOAP is sold everywhere, but insist on having Pears', as vilely injurious imitations are often substituted for extra gain, even by dealers who would be thought RESPECTABLE. some of whom attract the public into their shops or stores by marking Pears' Soap at less than cost price, and then recommend some rubbish on which they get a large profit.

Figure 4.4 Advertisement for Pears' soap with quote by Wilson. Date unknown. Wellcome Library, London. 


\section{Chapter 4}

"the soap manufacturer". ${ }^{135}$ Apparently, Pears had met with a member of the medical profession and stated that he had a partnership with Mr. Erasmus Wilson. The aim of the author of the letter was to firmly deny all communication between Pears and Wilson:

I know that Mr. Wilson has never had any communication with Messrs. Pears firm except through myself. I had some months ago to compel the Firm under threat of proceedings by Injunction to alter at a great expense the whole of their advertisements and this they have done- and with the exception of this I know that Mr. Wilson has never had anything to do with them - Indeed I doubt if there is such a person as Pears in existence and I only regret I was unable to remove from the advertisement all mention of Mr. Wilson's name, but I could not do so as a statement to the effect of that made in the advertisement was incautiously inserted in a work edited by Mr. Wilson. ${ }^{136}$

Despite this statement we may assume that Wilson did not take any action to remove his name from the advertising campaign, since later advertisements still featured his name. In any case Wilson's appearance in the Pears advertisements, wanted or unwanted, created a connection between medical knowledge, skin cleanliness and soap.

In the new culture of consumption people depended less on their own production and more and more on the purchase of mass produced and mass marketed goods. Fashionable goods such as soap provided status and identity. ${ }^{137}$ The ideal of a clean skin was reproduced in this culture through the visual language of soap advertisements such as the Pears campaign. Wilson's name recurred in different advertisements, such as the one in figure 4.4. The plate with the name of Erasmus Wilson activates knowledge of the skin in a new environment. Soap imagery created a new popular, visual referent for the clean skin. In conclusion, we can say that the Pears soap advertisements composed and produced a commodified clean skin. The scientific depiction of skin was transformed and taken up into a new visual language: the skin as common good.

\section{Dirty boys and lovely ladies: norms and visual language}

By the end of the nineteenth century a new, compelling, visual imagery of skin had pervaded the public arena in Britain. Advertising campaigns for soap propagated the image of an ideal clean, beautiful, healthy and white skin. Whereas by the end of the eighteenth century beauty was still marked by a 'fair' skin without any signs of illness, the ideal skin should now be healthy and clean. The history of skin cleanliness gained currency in the morality of commercial soap pictures. Sanitary ideals were interwoven with mass-media marketing of commodities such as soap. The soap pictures became a powerful vehicle for the visual display of the norms of skin cleanliness. Unlike the

135 Manuscript MS. 8007/37/28. Part of larger collection of items on Erasmus Wilson: reference MS. 8007/37. Wellcome Library, London.

136 Idem.

137 Sivulka, J. (2001), p. 61. 


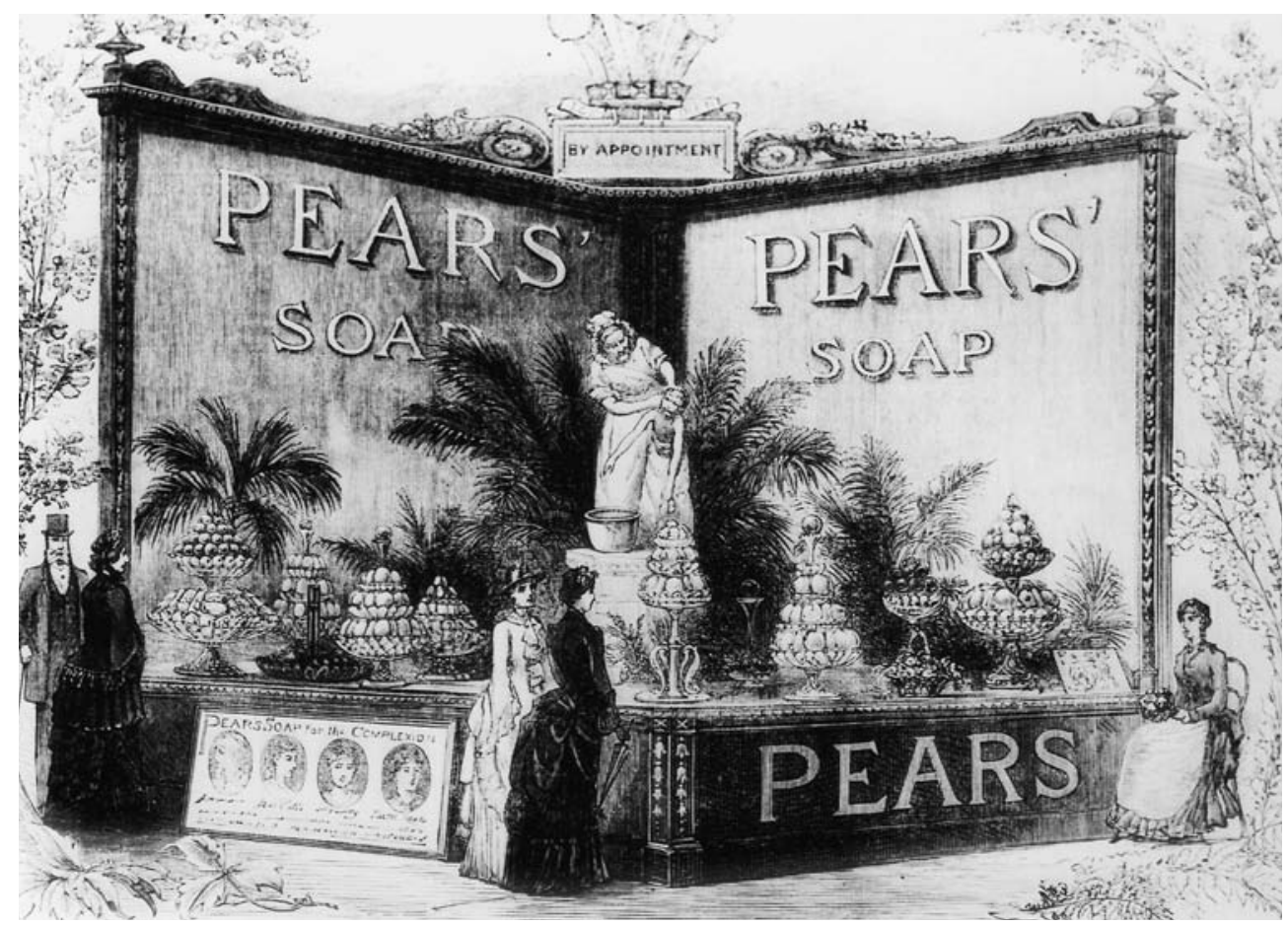

Figure 4.5 'You Dirty Boy' statue by Focardi as part of the Pears' Soap stand at the International Health Exhibition; Illustrated London News, 2nd Aug 1884, p.101.

pictures of skin diseases and microscopical pictures of skin discussed in the preceding chapters, soap advertisements explicitly connected knowledge of the skin with consumer products and a visual ideology of social norms and health. The Pears' soap advertising created a visual culture of skin cleanliness.

Times had changed since Wilson's Healthy skin first appeared in 1845. Sir Erasmus Wilson himself had now reached the status of a celebrity, both in the medical profession and in the eye of the public at large. In 1882 The Lancet published multiple reports informing its readers of the state of Wilson's health, then deteriorating. On April 22 the first report stated: "We are glad to be able to announce that the health of Sir Erasmus Wilson is improving." 138 The concern for Wilson's health came after busy years for him. He had established a paid chair of dermatology at the Royal College of Surgeons, for which he was appointed professor by the Council between 1870 and 1878 . He had also been heavily engaged in philanthropy and in 1881 served as president of the Royal Society of the College of Surgeons. After two years of illness, The Times announced on August 91884 that the "man who knew more about skin disease than any other man of his time" had deceased. ${ }^{139}$ For the general audience the name Erasmus Wilson remained 
well-known as it reminded people of his famous transport of the Egyptian obelisk to Britain in 1871. His name had penetrated into society through the many slogans in the Pears' soap advertisements. Ads for Pears' soap diffused more and more widely through British society in magazines, posters and newspapers. Depicted in colourful ads, Wilson's name had become equivalent to the importance of clean skin in Britain.

Pears' soap advertising acted as a powerful visual language of skin cleanliness. The moral virtues of skin cleanliness were depicted in the late Victorian soap advertising campaign. In the visualisation process new visual codes of skin cleanliness were put forward. When Thomas Barratt became the sole owner of the Pears' soap business, he used colourful advertisements and strong slogans to promote his product in Britain and America. One of his famous strategies was to deploy artworks in his advertising. His commercial exploitation of the painting "A Child's World" by John Everett Millais (1886) became famous as an icon for child innocence in relation to soap and cleanliness as a picture named "Bubbles". ${ }^{140}$ Another less known but more meaningful example with regard to skin cleanliness is Barratt's use of a statue by Giovanni Focardi from 1878 entitled "You Dirty Boy". The terracotta statue was made for Pears by order of Barratt as a shop display figure. It was also prominent on the Pears soap stand at the International Health Exhibition in London in 1884 (see figure 4.5). ${ }^{141}$ Pictures of the figure were also used in black and white and coloured advertisements in

140 See also: Sivulka, J. (2001), p. 96; and Dempsey, M., \& Pears A. and F. Limited. (1978), p. 3-4. For an inspiring analysis of soap bubbles in art and physics see: Schaffer, S. (2004). A science whose business is bursting: Soap bubbles as commodities in classical physics. In L. Daston (Ed.), Things that talk. Object lessons from art and science (pp. 147-194). New York: Zone Books.

141 Part of the Pears Soap Stand at the International Health Exhibition; Illustrated London News, 2nd Aug 1884, p.101. http://www.artandarchitecture.org.uk/images/conway/4b508d6a.html. 

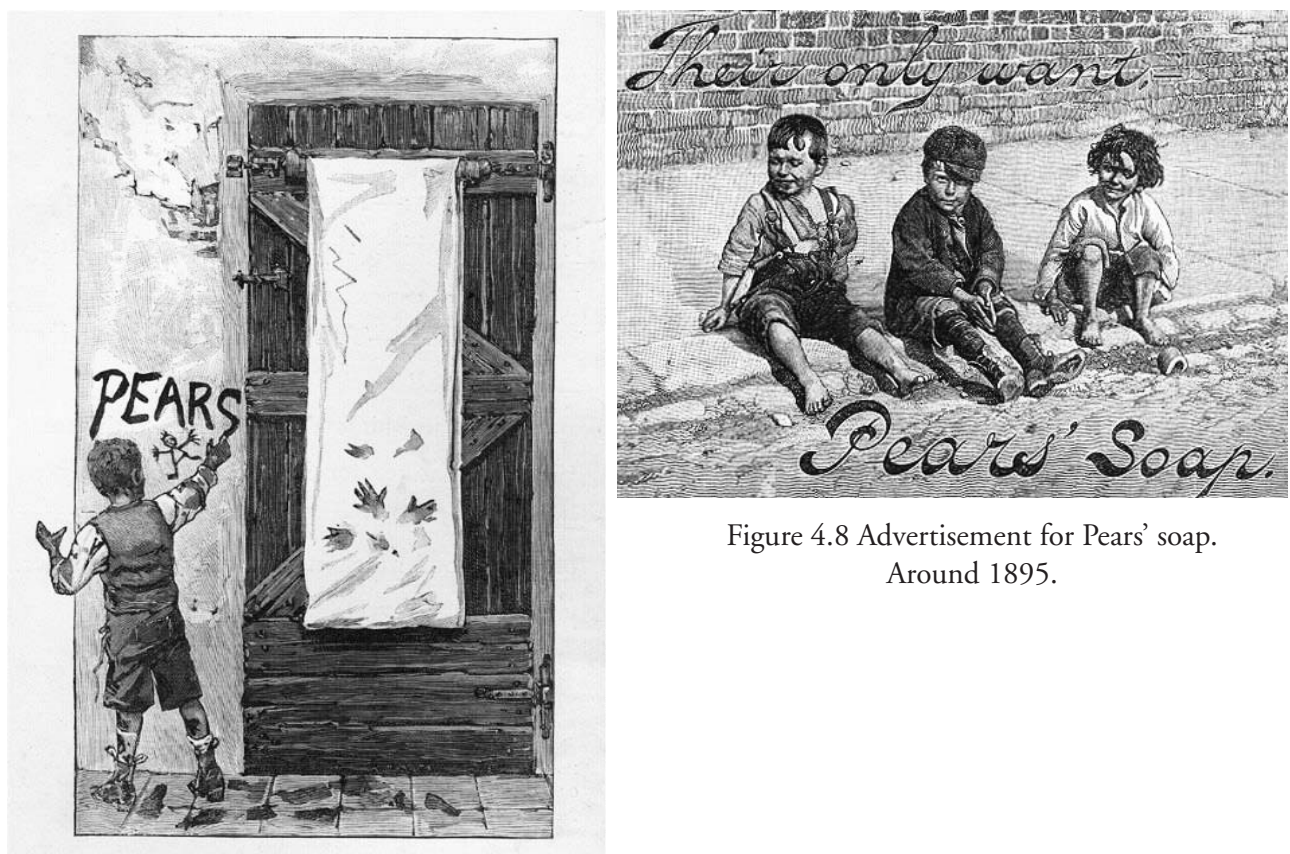

Figure 4.8 Advertisement for Pears' soap. Around 1895.

Figure 4.7 Advertisement for Pears' soap. Around 1894.

magazines (figure 4.6). The 'dirty boy' advertisements typically expressed the norms of skin cleanliness in a visual manner. These advertisements show us how the visual history of skin cleanliness was normatively charged.

The social norms of skin cleanliness were of great importance in Pears soap advertisements. The Dirty Boy ads connected dirtiness to improper behaviour. The word 'Pears' written on a wall by a dirty poor boy in clear need of a good wash in another ad was enough to recall the image of clean skin as a prerequisite for proper behaviour and escape from poor environments (see figure 4.7). Sloppy poor children were depicted in another soap ad stating the pressing line "Their only want, - Pears' Soap" (figure 4.8). Many ads visually propagated the highly esteemed norms of cleanliness by either pointing to those in need of clean skin or those who would embody the norms of cleanliness. Beautiful ladies with perfect white skin endorsed Pears' soap for "Healthful skin, good complexion and soft, white beautiful hands". The image of a nurse would further confirm Pears' soap as a symbol of cleanliness and purity (see figure 4.9). Shaving and washing monks were used to equate cleanliness to the highest morals of all: "Cleanliness is next to godliness" (figure 4.10). Happy babies and young children presented the soft innocence of young skin, while the dirty boy represented the skin in need of cleanliness, education and control. While the poor social classes took the form of the dirty boy who needed to learn 


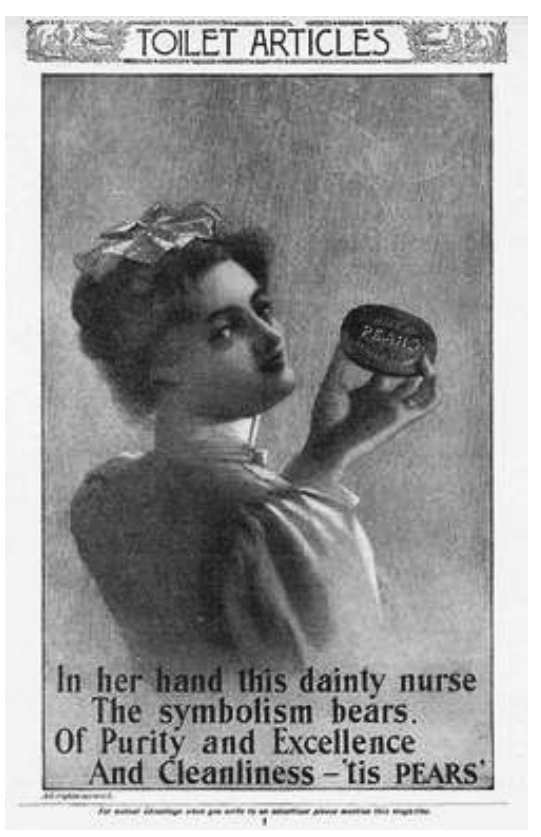

Figure 4.9 Advertisement for Pears' soap. Around 1899.

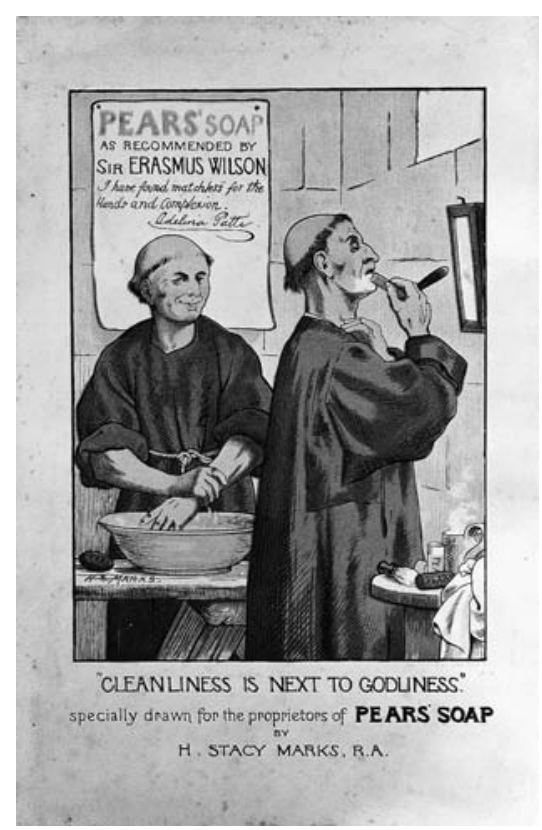

Figure 4.10 Pears advertisement showing monks washing and shaving, with endorsement by Erasmus Wilson.

Lithograph after H. Stacy Marks.

Date unknown. (18.5 x $12 \mathrm{~cm})$.

Wellcome Library, London.

about the norms of skin cleanliness, the norms of the middle classes were embodied by clean white women, holy figures and innocent children.

The normative overtone in the Pears advertising campaign was not restricted to skin cleanliness as merely healthy or beautiful. Some ads connected visual codes that had their origins in racial superiority and British imperialist drive. Feminist scholar Ann Mcclintock argued that "soap took shape as a technology of social purification, inextricably entwined with the semiotics of imperial racism and class denigration". ${ }^{142}$ In Pears' soap advertising the bar of soap was made into a superior means of civilising and brightening "the dark corners of the earth". ${ }^{143}$ Pears' soap would "civilise" the dark-skinned (figure 4.11). In advertisements the visualisation of middle-class values, varying from good manners and body control to imperialism, all took shape on the skin as a visual language. A visual language of clean skin symbolised and reinforced and empowered the norms of skin cleanliness.

The normative visual language of clean skin was widely spread in the lives of people in Britain from the 1880s. Middle-class citizens in cities were often confronted with the 


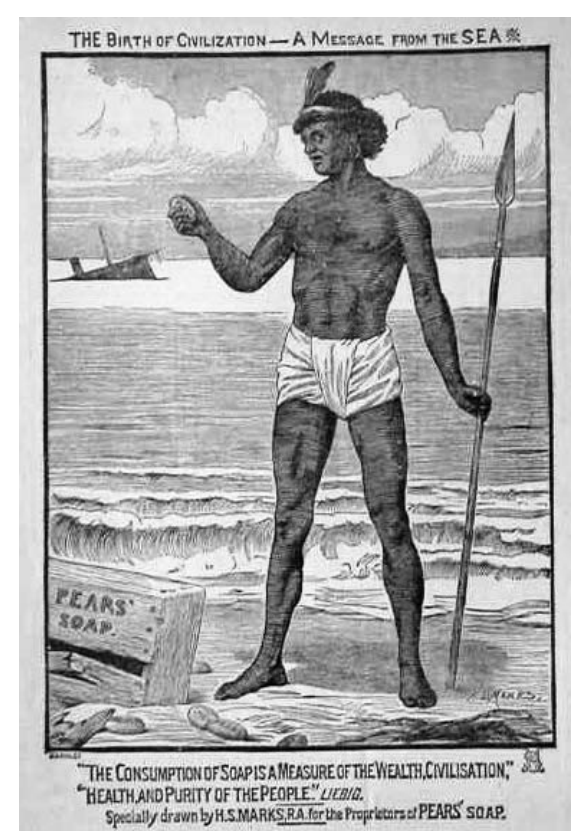

Figure 4.11 The Birth of Civilization - A Message from the Sea".

Advertisement for Pears' soap. Around 1886.

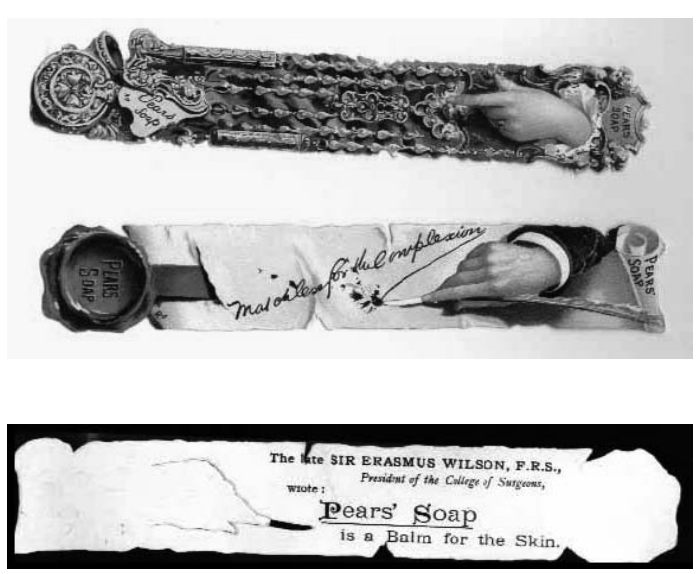

Figure 4.12 Pears' soap bookmarks. Date unknown.

mobility of this normative visual language. Pears advertisements were displayed in popular magazines, at train stations and even on bookmarks. Wilson's quote about Pears' soap was printed on the back of a bookmark, indicating both the dispersion of Wilson's name and the norms of skin cleanliness (figure 4.12). Even when reading a book one was visually reminded of the ideal of a clean skin. Ads were printed in popular magazines such as The Illustrated London News and in children's magazines such as the American St. Nicholas. Full-colour posters of celebrities such as actress and beauty Lillie Langtry endorsing Pears' soap were also present on London city transport. In the painting The Bayswater Omnibus from 1895 the artist G.W. Joy depicted several passengers inside a horse-drawn omnibus with a Pears soap advertisement embellishing the inside of the coach (figure 4.13). Clearly, the Pears advertisements had become an indispensable visual element of modern city scenery and life. A visual culture of skin cleanliness penetrated deeply into the lives and minds of many.

Paradoxically, while the concept of skin cleanliness gained in visuality, cleanliness lost its visibility. By the end of the nineteenth century a new understanding of cleanliness was based on a fight against the invisible monsters of bacteria: "(...) the whitest skin 


\section{Chapter 4}

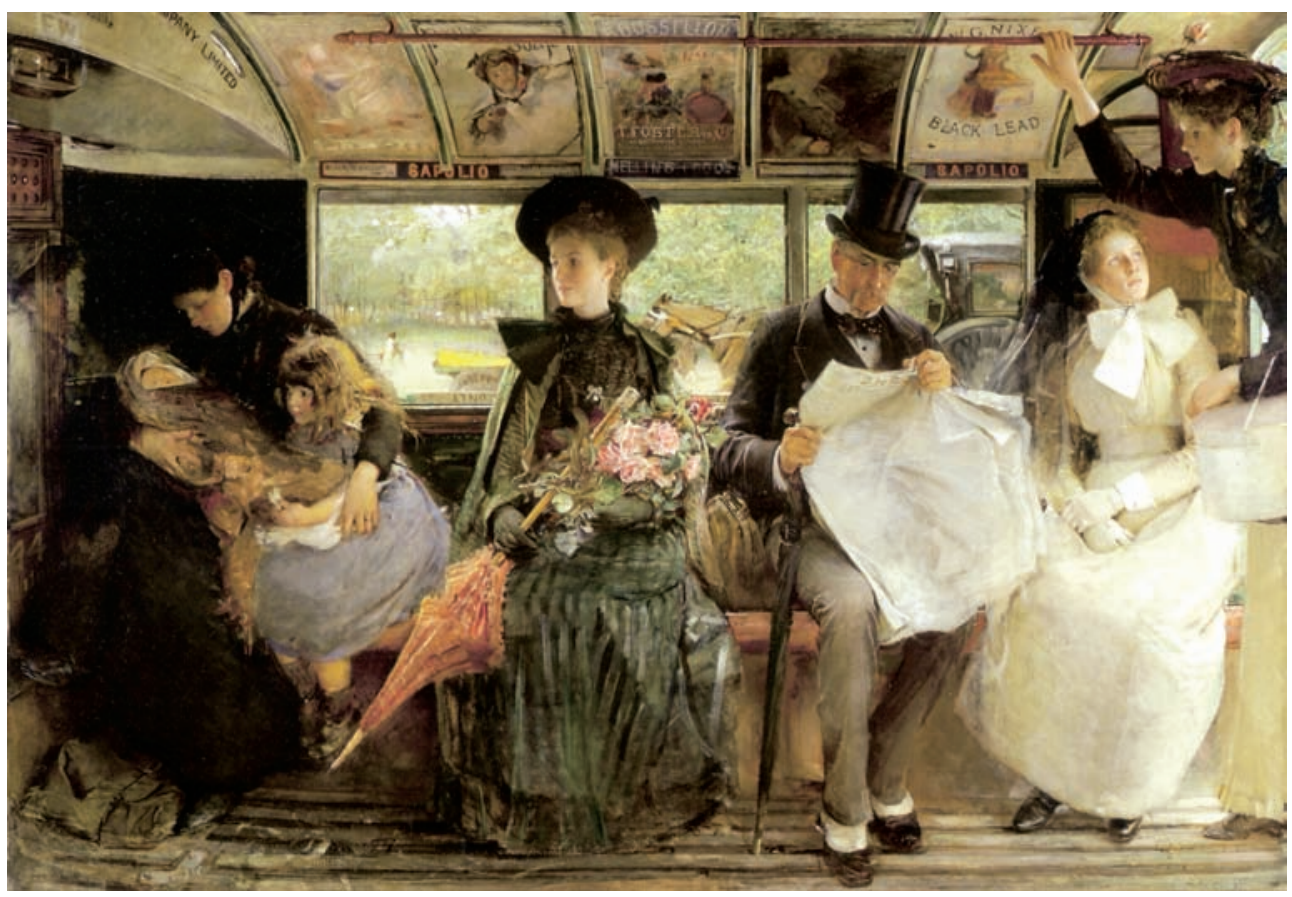

Figure 4.13 Pears' soap advertisement in painting The Bayswater Omnibus by G.W. Joy, 1895 $(172 \times 120 \mathrm{~cm})$, Museum of London.

might sustain every sort of bacteria. It was no longer possible to see what was dirty.". ${ }^{144}$ Therefore, with the development of a normative visual language of clean skin, cleanliness itself became invisible. Yet in the popular domain the morale of skin cleanliness remained visible in soap advertisements. By the early twentieth century the skin had acquired a burden of manifold norms, habits and commodities, all directed towards one aim: to be clean. 


\section{The colours of life}

\section{Early photography of skin diseases}

Photography interceded with the medical depiction of skin. While soap advertisements dominated the streets of London, physicians and specialists in skin diseases were beginning to explore the possibilities of photography. They did so with great enthusiasm. Physicians saw new promise for the depiction of skin diseases and the reproduction of patients in an unparalleled lifelike and accurate way. Specialists in skin diseases argued that with photography an objective, lifelike and accurate depiction of skin diseases finally came within their reach. Yet no physician could have foreseen how the use of photography would shape a new way of medical depiction and how it caused a commotion that reached far beyond medical matters of the hospital. Apart from new promise, unexpected challenges had to be taken up as well. This chapter examines what happened when physicians appropriated photography for depiction in dermatology during the second half of the nineteenth century.

Dermatological photographs were among the first medical photographs to be produced. The use of photography for the depiction of skin diseases should therefore be considered in the context of specialisation in medicine and the emergence of dermatology as a discipline. From the mid-nineteenth century onwards special branches of medicine and surgery were taking shape in German universities and teaching hospitals. Alongside disciplines such as ophthalmology, obstetrics, gynaecology and psychiatry, dermatology was taught in hospital clinics in Germany, France, Britain and America. Specialist hospitals for the treatment and study of skin diseases, chairs and departments of dermatology in general hospitals, local or national societies for dermatology and journals on skin diseases were set up and increasingly came to define dermatology as a discipline in these countries. Physicians of different scientific fields and branches of medicine had started using photography fairly soon after the invention of the daguerreotype method in $1839 .{ }^{1}$ From the 1860 s photographs became a popular means of documenting patients. Physicians regarded the photograph as a suitable didactic medium because it could mimic the clinical presentation of diseases in patients. How was photography taken up by dermatologists?

1 On the early uses of photographs in science and medicine see for example: Gilman, S. L. (Ed.). (1976). The face of madness: Hugh W. Diamond and the origin of psychiatric photography. New York: Brunner/Mazel; Fox, D. M., \& Lawrence, C. (1988). Photographing medicine: images and power in Britain and America since 1840. New York: Greenwood Press; Maehle, A. H. (1993). The search for objective communication: Medical photography in the nineteenth century. In R. G. Mazzolini (Ed.), Non-verbal communication in science prior to 1900 (pp. 563-586). Firenze: Leo S. Olschki; Thomas, A. (Ed.). (1997). Beauty of another order: photography in science. New Haven, London: Yale University Press in association with the National Gallery of Canada, Ottawa; Dermer, R. A. (Ed.). (1999). Medicine and photography [Special issue]. History of Photography, 23(3); Geimer, P. (Ed.). (2002). 


\section{Chapter 5}

What changed in the way skin diseases were depicted when photography emerged as a new visualisation technology? The appropriation of photography by dermatologists offers an interesting case to follow the developments of new standards for depicting diseased skin.

The use of photographs for the depiction of skin diseases in the latter half of the nineteenth century was also connected with developments outside the specialist and professional domains of medicine. Popular conventions induced a visual language of clinical portraits of patients, comparable to popular contemporary portraits. Even for such a seemingly specialist terrain as photography in dermatology, popular pictorial standards initially played a role. How the introduction of a new visualisation technology can lead to unexpected encounters with popular portraits and how the introduction of photography becomes part of a wider discussion on privacy and depiction are also the subject of this chapter. Where the previous chapter focused on the normative aspects of popular visual languages of skin, this chapter returns to the depiction of diseased skin. How did the visual language of diseased skin change when dermatologists appropriated photography for their own purposes? In this chapter the tensions and encounters between old and new illustration technologies for depicting skin diseases, as well as popular and specialist visualisation practices and standards are discussed.

A long-term perspective on photography as a new visualisation technology for dermatology shows how physicians specialising in diseased skin appropriated this novel technology for their own needs. Simultaneously though, unexpected and even unwanted 'effects' of the use of photography as visualisation technology played an important part as well. For physicians as new 'users' of photography the photographs as (visualisation) technology only became functionally important when they were fitted and moulded to meet their needs in the medical context. In this sense I use the term 'appropriation' to emphasise that photography as a technology does not merely refer to physicians who used photography just as a technical artefact. Instead, the appropriation of photography in dermatology involved translations and interaction between photographic equipment, photographers, dermatologists, skills, pictorial and cultural conventions and medical knowledge. ${ }^{2}$ In this chapter I show that the appropriation of photography in dermatology was not a straightforward process, but that it involved the development of new pictorial standards to distinguish between popular and medical specialist photographs.

For a long time medical historians had disregarded the role of photographs. Recently, however, photography of the body has become a favourite and important subject for

2 My understanding of appropriation is in line with the views of appropriation of technology in cultural and media studies: "Their central thesis is that technologies must be culturally appropriated to become functional" in: Oudshoorn, N., \& Pinch, T. (Eds.). (2003). How users matter: the co-construction of users and technology. Cambridge, Mass: MIT Press, p. 12. In my analysis I withhold from the sophisticated interpretations of the term 'appropriation' as used in art history, cf.: Nelson, R. S. (2003). Appropriation. In R. S. Nelson \& R. Shiff (Eds.), Critical terms for art history (2nd ed., pp. 160-173). Chicago: University of Chicago Press. 
many scholars in the field of cultural studies and art history. ${ }^{3}$ As early as the 1950s and mid-1970s historians had started looking more closely at early medical photography in the nineteenth century. ${ }^{4}$ These pioneering historians provided useful inventories and overviews of medical photographic publications. Yet they still mostly regarded the photographs themselves as self-evident historical sources reflecting a past reality. From the late 1970s scholars began to approach photographs as more than a simple source and came to analyse the role and meaning of photographs in different cultural and medical practices. ${ }^{5}$ So far the medical appropriation of photography in dermatology has not been studied. Following historian John Tagg, I discuss photographs in this chapter not as "a magical 'emanation' but as a material product of a material apparatus set to work in specific contexts, by specific forces, for more or less defined purposes". ${ }^{6}$ Countering the view of Roland Barthes, in his work The burden of representation Tagg urges us not to see the photograph as an inflection of a prior reality, but as a material item which produces a new and specific reality and "becomes meaningful in certain transactions and has real effects". 7 Accordingly, I will deal with the roles photographs attained in the clinical practice of dermatology.

Dermatological photographs were important for the emergence of medical photography. As such, their history provides us with interesting insights into the earliest motives for using photography to depict diseases. From the outset medical photography was not a field by and of itself. Early dermatological photographs, together with other specialised photographs, formed the basis for an emerging field. Dermatologists had their own expectations of photography and at the same time met with the unexpected effects of photography for the depiction of skin diseases in unruly practice. In this chapter photographs of skin diseases from England, France and America are discussed. Over 150 photographs were made public in dermatological photographic atlases published between 1865 and 1900. The photographs provide us

3 On photography of the body see for example: Sekula, A. (1989). The body and the archive. In R. Bolton (Ed.), The contest of meaning: critical histories of photography (pp. 343-388). Cambridge, MA: MIT Press. For a discussion of medical photography in a cultural historical perspective see: Didi-Huberman, G. (2003). Invention of hysteria: Charcot and the photographic iconography of the Salpêtrière (A. Hartz, Trans.). Cambridge, Mass: The MIT Press. Photography is furthermore one of the key modern visualisation processes in visual culture studies: Slater, D. (1995). Photography and modern vision: The spectacle of 'natural magic'. In C. Jenks (Ed.), Visual culture (pp. 218-237). New York: Routledge; Mirzoeff, N. (1999). An introduction to visual culture. London: Routledge, pp. 65-90.

4 Burns, S. B. (1979a). Early medical photography in America (1839-1883). New York State Journal of Medicine, 79(5), 788-795; Gernsheim, A. (1961). Medical photography in the nineteenth century, Part I. Medical and Biological Illustration, 11, 85-92; Hansell, P. (1959). Victorian clinical photography. Medical and Biological Illustration, 9, 7077; Ollerenshaw, R. (1968). Medical illustration. The impact of photography on its history. Journal of the Biological Photographic Association, XXXVI, 3-13; Taureck, R. (1980). Die Bedeutung der Photographie für die medizinische Abbildung im 19. Jahrh. Köln: Universität zu Köln.

5 See for example: Fox, D. M., \& Terry, J. (1978). Photography and the self image of American physicians, 18801920. Bulletin of the History of Medicine, 52, 435-457; Kemp, M. (1997). "A perfect and faithful record": mind and body in medical photography before 1900. In A. Thomas (Ed.), Beauty of another order: photography in science (pp. 120-149). New Haven: Yale University Press. For other more recent works on medical photography see references in note 1 .

6 Tagg, J. (1988). The burden of representation. Houndmills: Macmillan Press, p. 3.

7 Idem. 


\title{
Chapter 5
}

with histories of the nature and practices of medical photography.

Photographs of patients with skin diseases published between 1865 and 1900 mark a crucial, transitional period in dermatological and medical depiction, dermatology as a discipline and depiction in popular culture. This chapter illustrates what kinds of pictorial traditions were present, augmented and reformed with the advent of photography as a new visualisation technology. The first section introduces the early photographic atlases in dermatology. The following sections discuss the appropriation of photography in dermatology by referring to the changes in existing visual languages of diseased skin. I show how the old meets the new, how manual artistic crafts meet the mechanical eye of the photographic apparatus and how tradition joins innovation to produce a new form of depiction. In the latter part of the chapter I then argue for the importance of the contested nature of medical photographs at the end of the nineteenth century. Finally, processes of standardisation and institutionalisation in medical photography show how boundaries were constructed to demarcate medical photographs from popular pictures.

\section{Early works}

\begin{abstract}
The study of Skin Diseases without cases or coloured plates is like the study of osteology without bones, or the study of geography without maps. (...) It has been the aim of the author to represent in this series nearly all of the rare as well as the common afflictions of the skin (...) to present their features with photographic accuracy, and to employ color with the utmost care to render the illustrations as life-like as possible. ${ }^{8}$
\end{abstract}

Illustrations were indispensable aids in dermatology throughout the nineteenth century. With the entry of photographic methods for the illustration of skin diseases, accuracy and lifelikeness were brought to the fore as the most important advantages. Indeed, authors of the earliest photographic atlases of skin diseases pointed time and again to these striking qualities of photographs. Skin disorders were among the first fields in medicine where photographic methods were employed. For physicians studying patients with skin diseases photography was considered a visualisation technology par excellence. The publication of the first journal on medical photography in 1869 even directly followed upon the success of a French photographic atlas on skin diseases. The outward manifestations of skin diseases seemed the perfect prey for the all-registering eye of the camera and several photographic atlases were published. In this section I introduce these early photographic atlases of skin diseases.

Shortly after the announcement of photography to the world in 1839, the process became part of scientific and medical practices. In 1839 the Frenchman Louis Daguerre had invented the process of recording camera pictures on metal plates with the utmost precision. Meanwhile, the Englishman Henry Fox Talbot was also working on processes to fix images permanently. In an announcement before the Royal Society in 1839 Talbot 
presented the magical process "by which natural objects may be made to delineate themselves without the aid of the artist's pencil" or photographic drawing. ${ }^{9}$ In his paper Talbot argued that his invention could be applied in the fields of art and portraiture and also for the fixation of microscopic images:

Contemplating the beautiful picture which the solar microscope produces, the thought struck me, whether it might not be possible to cause that image to impress itself upon the paper, and thus let Nature substitute her own inimitable pencil, for the imperfect, tedious and almost hopeless attempt of copying a subject so intricate. ${ }^{10}$

From the very start photography was used for the fixation of scientific and medical images. In the 1840 s physicians, microscopists and astronomers began experimenting with photographic processes for their illustrations. ${ }^{11}$ In America physicians were already using the daguerreotype for the recording of medical subjects by the late $1840 \mathrm{~s}^{12}$ Doctors took pictures of operations and patients with facial and neck deformities, for example. Following the introduction of the collodion process in 1851 and the improvement of the albumen process, the publication of works illustrated with printed photographs increased. With the introduction of the photomechanical collodion or wet-plate process, photographic prints became easier to reproduce and cheaper. Charles Darwin published The expressions of the emotions in man and animals in 1872, one of the first books illustrated with 'heliotypes', produced with the collodion process. ${ }^{13}$ Another method used for the illustration of scientific and medical works was the Woodburytype. With this process it was not possible to print directly onto print paper, resulting in books with tipped-in photographs.

Even in early applications of photographic processes in science and medicine authors always pointed to the accuracy of the pictures. In France two physicians intended to use daguerreotypes for their medical microscopic studies. Alfred Donné (1801-1878), head of the clinic at the Charité Hospital in Paris, published the Cours de microscopie together with his co-worker physician Léon Foucault in $1845 .{ }^{14}$ The Cours was accompanied by an atlas with engraved reproductions after the new micro-daguerreotypes. Using a specially designed apparatus, the "microscope-daguerreotype", Donné and Foucault recorded histological slides of bodily fluids such as blood, milk, mucus and sperm. ${ }^{15}$

9 Fox Talbot, W. H. (1980). Some account of the art of photogenic drawing, or, the process by which natural objects may be made to delineate themselves without the aid of the artist's pencil. In B. Newhall (Ed.), Photography: essays \& images. Illustrated readings in the history of photography. (pp. 23-30). New York: Museum of Modern Art. (Original paper published 1839).

10 Ibid., p. 27.

11 Krauss, R. H. (1978). Photographs as early scientific book illustrations. History of Photography, 2(4), 291-314.

12 Burns, S. B. (1979c). Early medical photography in America (1839-1883). III. The daguerrean era. New York State Journal of Medicine, 79(8), 1256-1268.

13 Krauss, R. H. (1978), p. 296.

14 Donné, A., \& Foucault, L. (1845). Cours de microscopie complémentaire des études médicales: anatomie microscopique et physiologie des fluides de l'économie. Paris: JB Baillière.

15 On photomicroscopy and its place in early medical photography see: Gernsheim, A. (1961), pp. 85-86; Maehle, A. H. (1986). Wie die Photographie zu ein Methode der Medizin wurde. Fortschritte der Medizin, 104(15), 63-65; Régnier, C. (1995). La photographie médicale (1839-1881). La revue du praticien, 45(7), 808-812. 


\section{Chapter 5}

Although the illustrations were still engravings after daguerreotypes, Donné stressed that the new illustration process bypassed the theoretical interventions from the author or the illustrator. Illustrations with an unknown accuracy were the result: "Profitant de la merveilleuse invention du daguerréotype, les objets se seront reproduits avec une fidélité rigoureuse, inconnu jusqu'ici, au moyen des procédés photographiques" ${ }^{16}$ According to Donné, the illustrations represented nature with great fidelity and detail. ${ }^{17} \mathrm{He}$ also saw great potential in the illustrations for teaching microscopy. Like the botanist, the teaching microscopist was now able to show and explain the microscopic image to his students as a daguerreotype. According to Donné, students would now be able to observe and study the microscopic object and recognise it later when looking through the microscope themselves. ${ }^{18}$ Microscopists such as Donné and Foucault were among the first to apply photographic techniques to visualise and disseminate pictures of bodily material in medicine. Later, physicians would refer to similar arguments of accuracy to stress the advantages of photographs of patients.

An important example of early photography of patients is the work of physician Hugh Welch Diamond (1809-1886). His photographs mark the start of photography of insane patients. ${ }^{19}$ Diamond used photography in studying the insane in the women's section of the Surrey County Asylum in England. As one of the founding members of the Royal Photographic Society, he set up a photographic darkroom and studio inside the Asylum, where he photographed typical cases of insanity. ${ }^{20}$ In the $1850 \mathrm{~s}$ Diamond used his photographs to define the visual signs of "types of insanity". ${ }^{21}$ For Diamond photography contained an unequalled potential for analysis, classification and communication. Among other things he praised the new technology for its "unerring accuracy" in recording external phenomena of diseases. ${ }^{22}$ In his view the photographs could be of great use for both diagnosis and treatment. Indeed, Diamond was one of the first physicians to propagate and integrate photographic techniques in medical practice itself. His undertaking of photography of patients thus marks the onset of the appropriation of photography in specific fields of medicine.

External bodily manifestations such as skin diseases were the prime subject in the early photography of patients. ${ }^{23}$ Medical interest in photography resulted in four kinds of photographs and photographic prints between 1840 and 1890: 1. photographs of

Donné, A., \& Foucault, L. (1845), p. 6.

Ibid., p. 9.

Ibid., p. 10.

19 On the origins of psychiatric photography see chapter 14 in: Gilman, S. L. (1982). Seeing the insane: a cultural history of madness and art in the western world, showing how the portrayal of stereotypes has both reflected and shaped the perception and treatment of the mentally disturbed. New York: Wiley in association with Brunner-Mazel; and Burns, S. B. (1980a). Early medical photography in America (1839-1883). V. Beginnings of psychiatric photography. New York State Journal of Medicine, 80(2), 270-282.

20 Gernsheim, A. (1961), p. 88.

21 Kemp, M. (1997), p. 136.

22 Gilman, S. L. (1982), p. 164.

23 For useful overviews of photographs used in medical works see: Taureck, R. (1980), pp. 191-222; and Burns, S. B. (1981). Early medical photography in America (1839-1883). VII. American medical publications with photographs. New York State Journal of Medicine, 81(8), 1226-1264. 
extreme cases with patients showing extraordinary gross physical deformities such as tumours; 2. war photographs of surgical cases, such as soldiers with amputated legs; 3. typical examples of diseases for classifications and typologies of external manifestations of diseases, such as photographs of skin diseases, and 4. photographs of external signs of mental (dys)function. After 1850 these kinds of photographs of patients were published in works from emerging specialist fields in medicine such as military medicine, psychiatry, orthopaedics, physiognomy and dermatology. ${ }^{24}$ Literary scholar Erin O'Conner reasoned that photography was particularly suited to recording patients in these specific fields because of their inherent relationship to the surface of the human body:

Able only to picture a deep problem indirectly, as a superficial swelling, a gross deformity, or a mark on the skin - a rash, a sore, a mole or even a horn - the medical photograph captures pathology as surface. It is for this reason that orthopaedic disorders, war wounds and skin conditions were among the most popular subjects of early medical photography. ${ }^{25}$

Dermatology was one of the first fields in medicine in which physicians started using photography to depict patients. An important early dermatological work illustrated with photographs was published by the English physician Alexander John Balmanno Squire (1836-1908) in 1865: Photographs (coloured from life) of the diseases of the skin. ${ }^{26}$ Squire's work contained 12 hand-coloured tipped-in photographs (original albumens) (see figure 5.1). Later, two other parts of the series containing six and five photographs were published. When he published Photographs (coloured from life) of the diseases of the skin in 1865, Squire was a surgeon at the West London Dispensary for Diseases of the Skin and lecturer at St. Mary's Hospital Medical School in London. He would later acquire a position in the British Hospital for Diseases of the Skin in London. As a physician writing on skin diseases, Squire took part in the strong development towards the specialisation of dermatology as a branch of medicine in the second half of the nineteenth century. ${ }^{27}$

Across Europe organised education in skin diseases as a special type of medicine was starting to grow from the 1850s. Apart from London and Paris as important places for learning about skin diseases, a new centre of gravity emerged in Vienna. The Austrian physician Ferdinand von Hebra (1816-1880) started his influential teaching centre on skin diseases in 1845. The teachings and works of Von Hebra and his followers, also known as the Vienna School of Dermatology, are often seen as the foundation of modern

24 See Maehle, A. H. (1993), p. 565; and Burns, S. B. (1980b). Early medical photography in America (1839-1883). VI. Civil War medical photography. New York State Journal of Medicine, 80(9), 1444-1469.

25 O'Connor, E. (1999). Camera Medica. Towards a morbid history of photography. History of Photography, 23(3), 232-244; quoted on p. 234.

26 Squire, A. B. (1865). Photographs (coloured from life) of the diseases of the skin. London: J. Churchill and Sons. For an overview of photographic works in dermatology see: Neuse, W. H. G., Neumann, N. J., Lehmann, P., Jansen, T., \& Plewig, G. (1996). The history of photography in dermatology: Milestones from the roots to the 20th Century. Archives of Dermatology, 132(12), 1492-1498.

27 Besides this photographic work, Squire published other books on skin diseases. Squire, A. J. B. (1868). A manual of the diseases of the skin. London: John Churchill (four editions between 1868 and 1887); Squire, A. B. (1878). Atlas of the diseases of the skin. London: J. \& A. Churchill, New Burlington Street. 


\section{Chapter 5}

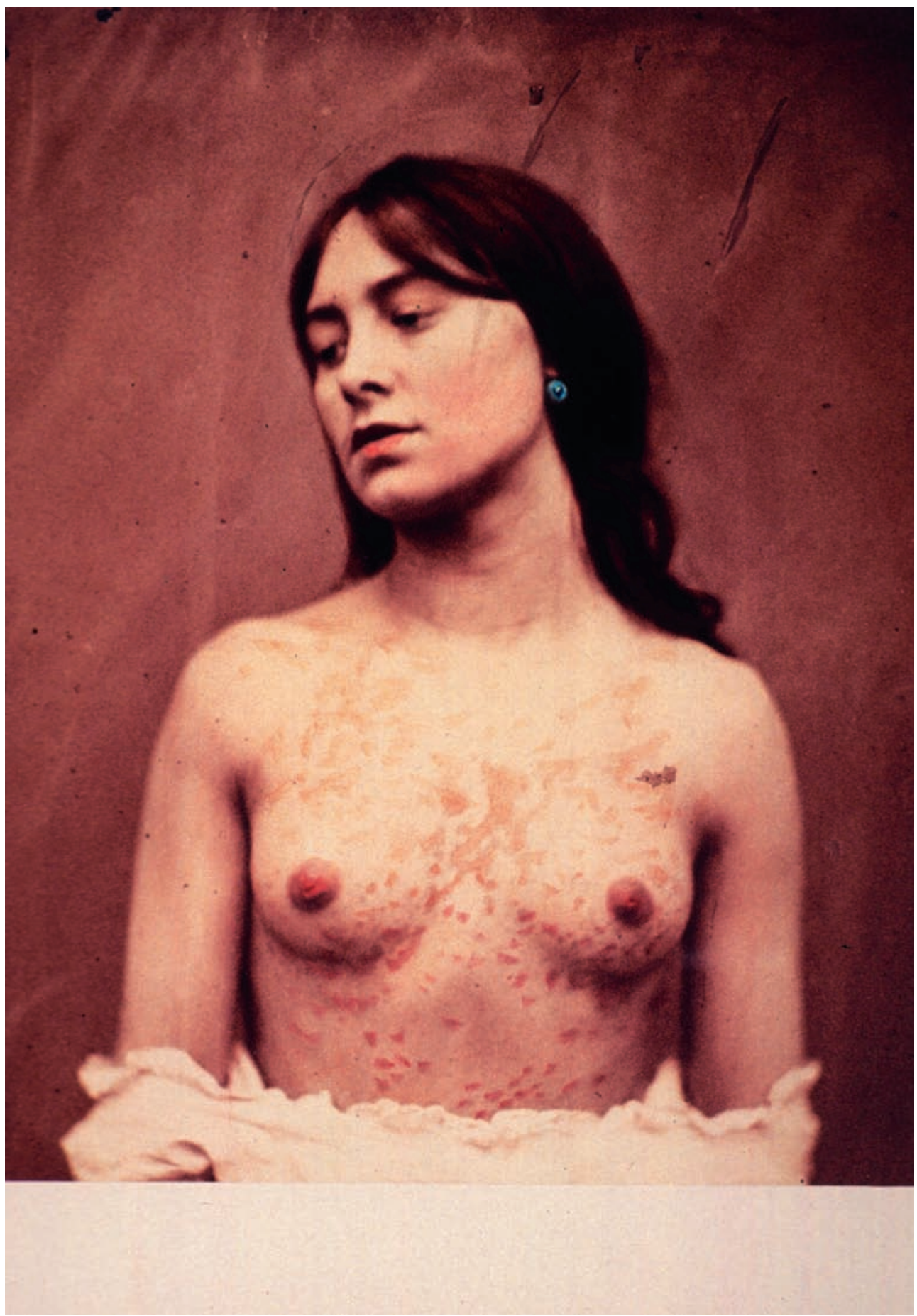

Figure 5.1 'Class V - Vegetable Parasite Diseases, Chloasma.' In Squire’s 1865 Photographs (coloured from life) of the diseases of the skin. $(30 \mathrm{~cm})$. National Library of Medicine, US. 
dermatology. ${ }^{28}$ Concentrating on the pathologies of the skin, Von Hebra introduced a new classification of skin diseases that considered skin disorders in close relation to the inner organs. He also very much concentrated on the study of clinical manifestations of skin diseases in patients in the wards at the Vienna General Hospital. Students from all over the world attended his clinic in Vienna and Von Hebra also maintained strong contacts with Paris and London. Two of Von Hebra's students, Isodore Neumann and Joseph Pick, established chairs of dermatology and founded the Archiv für Dermatologie in 1869. ${ }^{29}$ As the fame of Hebra's centre spread across the world, so dermatology grew in status as a separate discipline in medicine.

Squire's photographic work was an early individual experiment with the depiction of patients with skin diseases as a separate subject of medicine. Infused by a desire to depict his patients with diseased skin as accurately and as lifelike as possible, he decided to try photography:

The great difficulty hitherto experienced in producing illustrations adequately pourtraying the various diseases of the skin, induced me to try if greater accuracy and more life-like representation might not be obtained by means of photographs of diseases coloured from disease coloured from life by one of the best artists. ${ }^{30}$

For Squire the rationale behind the use of photographs for the illustration of diseased skin therefore resided in their 'accuracy' and 'life-likeness'. He also deemed the photographs useful for practical research and comparisons between different clinical cases:

\footnotetext{
My original object in making the experiment was to assist myself in researches into the pathology and treatment of the diseases of the skin. I was thus enabled, by securing accurate representations of remarkable cases, to compare them with other similar cases that subsequently came under my care. It soon became evident that excellent results were to be obtained by this means, and that they might be rendered more widely available by publication. ${ }^{31}$
}

To Squire the photographs as depiction became a stand-in or referent for the actual patient. The format of Squire's work reinforced the conception of the photograph as similar to the case of the patient. Every photograph was accompanied by two pages of text explaining the class of disease at hand, together with the specific case history of the patient. In the photograph clinical information about the patient and general information on skin diseases coincided. Using photographic illustrations he presented his fellow physicians interested in skin diseases with both specificity of the clinical case

28 On Hebra see: Finnerud, C. W. (1952). Ferdinand von Hebra and the Vienna School of Dermatology. A.M.A. archives of dermatology and syphilology, 66, 223-232; and Kimpel, M. (1981). Über den Atlas der Hautkrankheiten (1856-1876) von Ferdinand von Hebra (1816-1880). Köln: Institut für Geschichte der Medizin der Universität.

29 For an overview of Von Hebra's students see: Ormsby, O. S. (1949). History of dermatology, 1847 to 1947. Archives of Dermatology and Syphilology, 59, 374-395; quoted on pp. 375-376.

30 Squire, A. B. (1865), Advertisement.

31 Idem. 


\section{Chapter 5}

of the patient and the general background of the disease.

Squire's photographic work did not pass unnoticed. In 1866 the photographs came to the attention of the French professor of pathology Alfred Hardy of the Hôpital Saint Louis. ${ }^{32}$ Hardy (1811-1893), who specialised in skin diseases, decided to try this new process of dermatological iconography with the help of his student A. de Montméja. ${ }^{33}$ Their efforts resulted in a series of 12 numbers of Cliniquephotographique de l'hôpital SaintLouis (1867-1868), later compiled in a single volume (see figure 5.2). ${ }^{34}$ De Montméja, head of the ophthalmology department at the hospital and novice amateur photographer, was responsible for the 49 albumens of skin diseases. The mounted photographic prints were hand-coloured by de Montméja to bring out the diseased parts of the skin on the black and white albumens. Hardy directed and supervised de Montméja's work. Like Squire, Hardy praised the accuracy of the photographs. ${ }^{35}$ Compared to other illustration techniques such as lithography, photography was more accurate and cheaper. Hardy mentioned the low price of his photographic work in comparison with a work illustrated with coloured lithographical plates. ${ }^{36}$ All the inconveniences of traditional illustration techniques could be overcome by photography. At least, that was what Hardy was hoping for.

The French Clinique photographique was intended for a medical audience keen to learn about skin diseases. According to Hardy, coloured illustrations were indispensable for the study and diagnostics of skin diseases. His aim was to use photography to reproduce the most common types of diseases of the skin. Diagnostics of skin diseases depended to a large degree on the visual identification of colour nuances and detailed configurations on the skin. Hardy therefore argued that for medical students the practice of visiting and examining patients in the ward of the clinic in the hospital was essential to learn about the specific characteristics of skin diseases. However, not everybody was able to see patients for themselves at all times. The photographic work could then function as a substitute for the visual clinical experience:

\footnotetext{
Mais comme tout le monde n'est pas à la même d'avoir continuellement sous les yeux des exemples vivants d'affections cutanées, on a cherché à remplacer les malades par des planches coloriées. (...) C'est un recueil clinique destiné à faciliter l'étude des maladies de la peau, aussi bien pour les étudiants qui veulent les apprendre que pour les médecins qui éprouvent le besoin de les revoir et de se familiariser avec certains détails de ces afflictions. ${ }^{37}$
}

With the help of the photographs as diagnostic learning tools, students and physicians

32 One may assume that the following quote refers to the work by Squire: "Dans le courant de l'été de 1866, M. Hardy eut connaisaance d'essais photographiques faits en Angleterre, (...)”. Hardy, A., \& de Montméja, A. (1868). Clinique photographique de l'hôpital Saint-Louis. Paris: Librairie Chamerot et Lauwereyns, Préface, p. II.

33 Ibid: "iconographie dermatologique".

34 Hardy, A., \& de Montméja, A. (1868). Second edition: (1878). Clinique photographique des maladies de la peau. Paris: Lauwereyns. Third edition 1882.

35 Hardy, A., \& de Montméja, A. (1868), Préface p. I.

36 Idem.

37 Idem. 


\section{The colours of life}

\section{MALADIES PARASITAIRES}

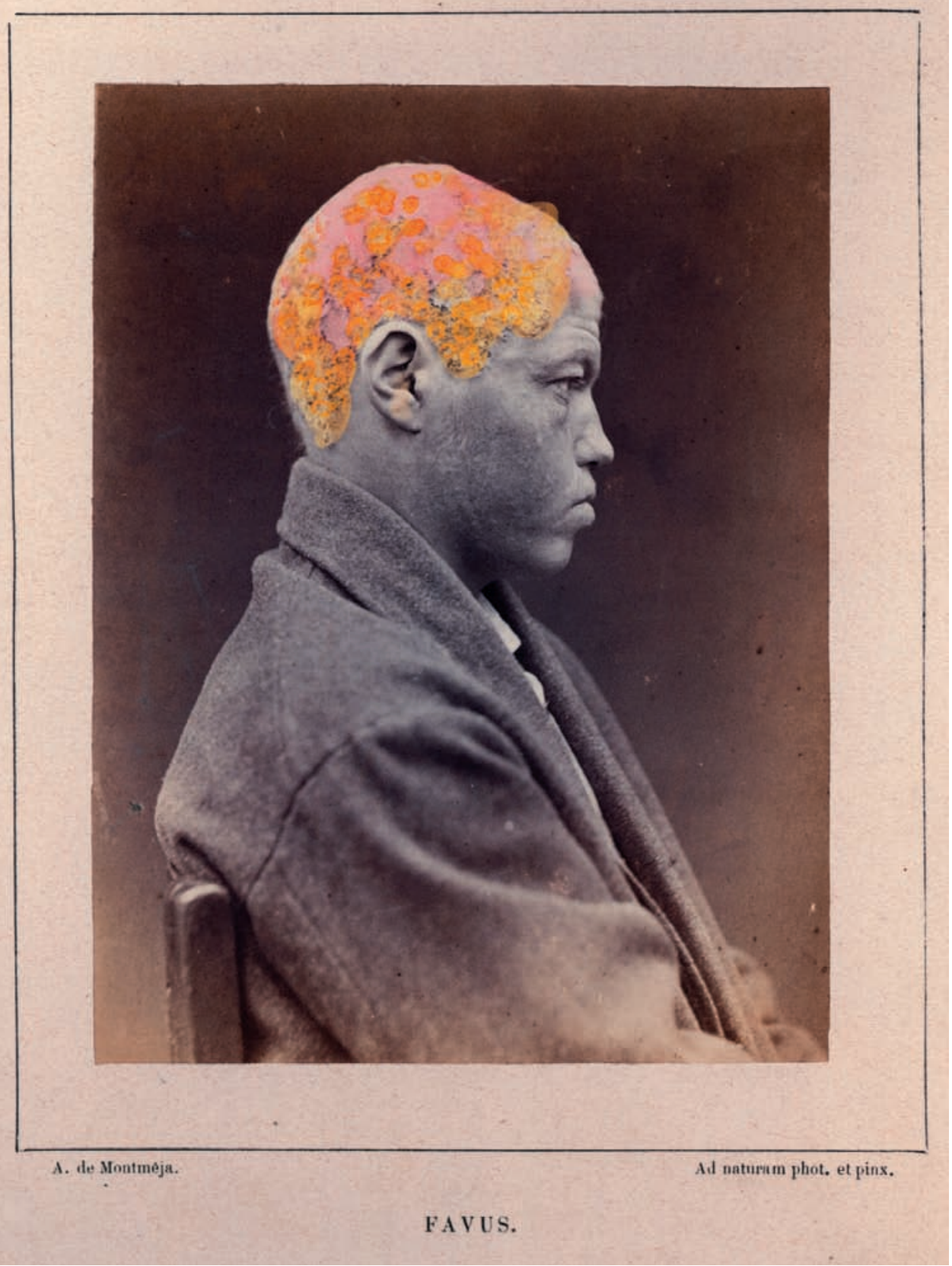

Figure 5.2 'Favus'. In Hardy, A., \& de Montméja, A. (1868). Clinique photographique de l’hôpital SaintLouis $(29 \mathrm{~cm})$. ). (C) BIUM Paris.

http://www.bium.univ-paris5.fr/histmed/medica/page?37462\&p=50 


\section{Chapter 5}

would be able to recognise the typical nature of skin diseases in their daily practice.

De Montméja’s pioneering photographical activities were of key value for the uses of photography in Paris hospitals. A special photographic "atelier" was established on the premises of the Saint-Louis hospital to accommodate de Montméja’s photographical activities. He became the head of the workshop, where he delegated and himself participated in the photographical operations. ${ }^{38}$ Here, the most interesting and rare pathologies from the Hôpital Saint Louis and the Salpêtrière (hospital for the insane and women's medicine) were captured on photographic plates. These photographs were published in the first journal on medical photography, the Revue photographique des hopitaux de Paris, which appeared between 1869 and $1872 .{ }^{39}$ The journal contained articles and photographs of the most rare and interesting cases in the Paris hospitals, written by prominent scientists and specialists. The formation of the Revue was a direct result of the popularity of the dermatological photographs in the Clinique photographique:

Un mode d'illustration, tout à fait nouveau en médecine, nous permet de joindre à cette Revue des planches dont la vérité est toujours supérieure à celle de tout autre genre d'iconographie. Les avantages de la photographie appliquée à la médecine ont valu un plein succès à la clinique photographique des maladies de la peau, par MM. A. Hardy et A. de Montméja. Nous espérons que notre journal, réunissant ces mêmes avantages et ceux qui peuvent résulter d'une plus grande expérience, saura mériter une pareille faveur. ${ }^{40}$

Next to his editorial work for the journal on medical photography, de Montméja also worked on photographs in the field of eye surgery. ${ }^{41}$ Other well-known medical photographic journals in France, such as the Iconographie photographique de la Salpêtrière and the works of Albert Londe and Charcot on hysteria and neurological disorders in women, may be viewed as spin-offs from the early photographic activities of Hardy and de Montméja on skin diseases. ${ }^{42}$

Outside Europe too physicians followed the example of Squire. Shortly after Hardy and de Montméja, the American physician Howard Damon (1833-1884) published his Photographs of skin diseases (1870), which carried 24 mounted albumens. ${ }^{43}$ In the preface to his work Damon showed that he was well-informed about previous photographic works in the field of dermatology by referring to Squire and Hardy. ${ }^{44}$ Another more extensive American photographic work on skin diseases appeared in 1880. As one of the pioneers in American dermatology, George Henry Fox published several photographic works on skin diseases. Photographic illustrations of skin diseases by Fox ran into several

38 See Préface by A. de Montméja in Hardy, A., \& de Montméja, A. (1868).

39 Montméja, A. de, \& Rengade, J. (Eds.). (1869). Revue photographique des hôpitaux de Paris. Paris: Adrien Delahaye, Libraire-Éditeur. Between 1870-1872 edited by de Montméja, A. \& Bourneville.

40 Montméja, A. de, \& Rengade, J. (Eds.). (1869), Avant-propos.

41 Meyer, E., \& Montméja, A. de (1871). Traité des opérations qui se pratiquent sur l'oeil. Paris: Lauwereyns.

42 Bourneville, D. M., \& Regnard, P. (Eds.). (1875). Iconographie photographique de la Salpêtrière. Paris: A. Delahaye.

43 Damon, H. F. (1870). Photographs of skin diseases. Boston: James Campbell.

44 Ibid., Preface. 


\section{The colours of life}

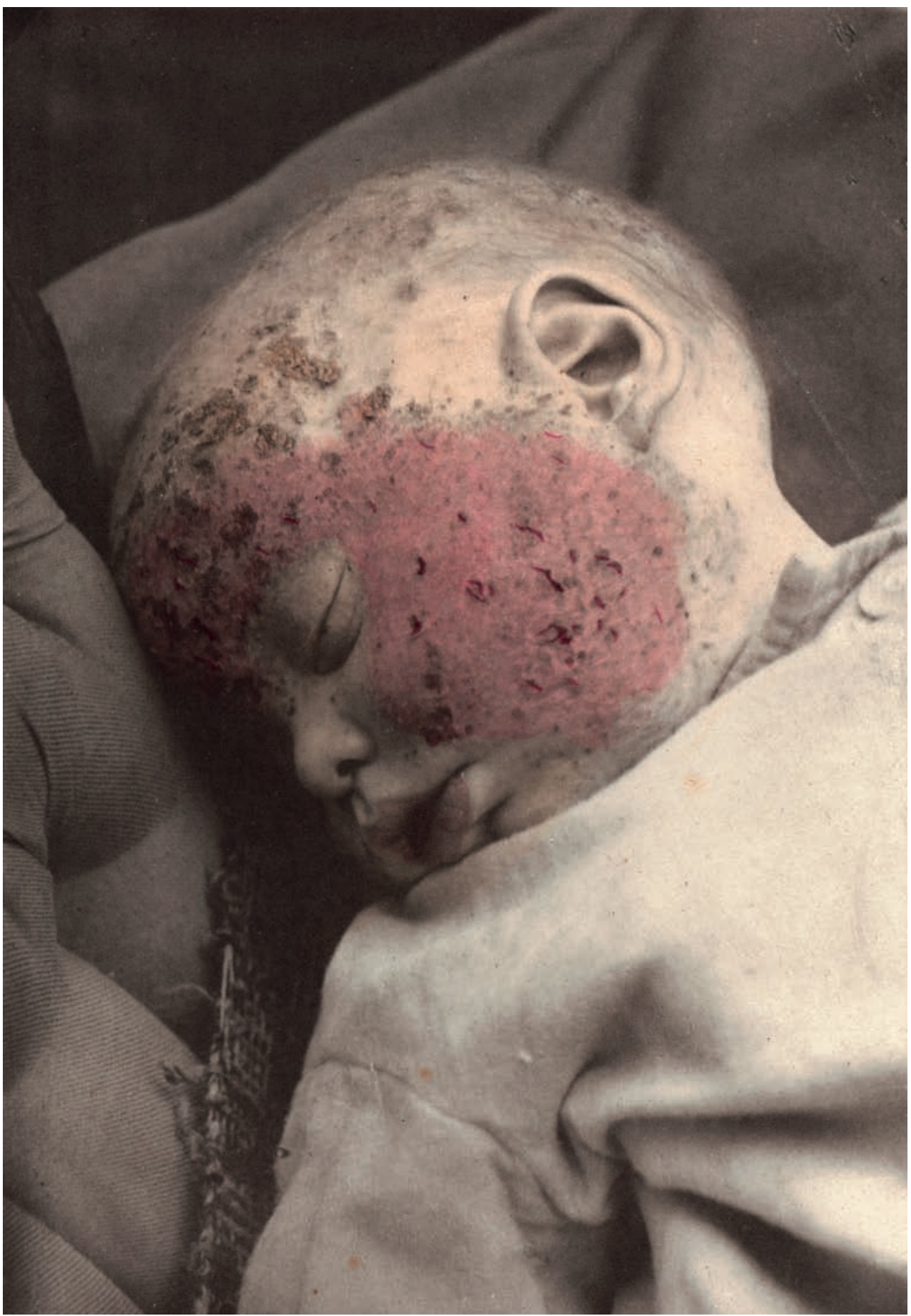

Figure 5.3 'Eczéma infantile.' Planche VII. In Fox, G. H. (1882). Iconographie photographique des maladies de la peau (J.-B. Holman, Trans.) (in-4 ). Library Universiteit van Amsterdam. 


\title{
Chapter 5
}

editions and was translated into French. ${ }^{45}$ It contained 48 plates "from life colored by hand", and would remain the foremost American dermatological atlas for 30 years (figure 5.3). ${ }^{46}$ Like Squire and Hardy, Fox was aiming for a medical audience of students and physicians. His aim was to represent both rare and common disorders of the skin in so-called 'artotypes'. The artotype, a modified albertype process, became one of the most popular kinds of published mechanical photographs in America. ${ }^{47}$ Fox enthusiastically introduced the advantages of the artotype process for depicting skin diseases compared to common photography (i.e. tipped-in albumen photographs):

\begin{abstract}
Photographs, though serving a good purpose in portraying the characteristic location and configuration of the various affections of the skin, have generally lacked an essential element of diagnosis, viz., the color, or have been disfigured by careless daubing, and coloured lithographs have not only been expensive, but in too many lacked fidelity to nature both in form and color. In the series of illustrations now offered to the profession, advantage has been taken of a process recently devised for the reproduction of pictures from photographic negatives. These pictures not only possess the sharpness of detail and brilliancy of ordinary photographs, but, unlike the latter, will not fade through age and exposure to light. ${ }^{48}$
\end{abstract}

The artotype reproduction allowed for cheaper and larger edition runs, so Fox could reach a larger audience than authors of photographic works of skin diseases before him. Like Squire and Hardy, Fox emphasised the accuracy of photography and the importance of the photographs for diagnostics. Fox noted that "a systematic course of clinical study is only possible in our large cities, and yet the physician in any remote locality may be called upon to treat the rarest forms of skin disease" ${ }^{49}$ Photographs were to overcome this problem, as they were the key to providing correct diagnostic information to the reader. Being both 'accurate' and 'life-like', they were praised as the ideal depiction of skin diseases.

The photographic works in dermatology show how physicians interested in the study of skin diseases embraced photography as a technology with great potential. Low cost, accurate representation and lifelike depiction of the patient were seen as the most important advantages of photography. Accurate depictions were considered indispensable aids in the teaching of dermatology as a rising separate branch of medicine. Yet the reception of photography did not take place in a pictorial vacuum in dermatology. If we want to understand the appropriation of photography in dermatology, we also have

Fox, G. H. (1880). Second American edition: 1889. French edition: Fox, G. H. (1882). Iconographie photographique des maladies de la peau (J.-B. Holman, Trans.). Paris: Librairie J.-B. Ballière et Fils. Later photographic works from George Fox include: Fox, G. H. (1881). Photographic illustration of cutaneous syphilis. New York: E. B. Treat; Fox, G. H. (1905). Photographic atlas of the diseases of the skin: a series of ninety-six plates, comprising nearly two hundred illustrations, with descriptive text, and a treatise on cutaneous therapeutics (Physician's ed.). Philadelphia; London: J.B. Lippincott.

46 Burns, S. B. (1981), p. 1243.

47 Ibid., p. 1231.

48 Fox, G. H. (1880), Preface.

49 Idem. 
to examine the relationship between photographs and existing ways of depicting skin diseases.

\section{Extending traditions}

When photographic processes became available and accessible to physicians working on skin diseases, they tried to integrate the new technique into existing traditions of depiction. To a large extent early photographs were to continue in existing pictorial styles. As in the first half of the nineteenth century, visual representation continued to play a crucial part in the study of skin diseases. As argued in chapter two, not only did illustrations of skin diseases serve as an extension of dermatological knowledge, they also shaped knowledge development. Two ways of depicting skin diseases emerged in the early decades of the nineteenth century: one emphasising the abstracted local morphology of primary lesions of the diseases and the other emphasising the clinical pathology of the patient as presented before the physician. These ways of depicting skin diseases became more and more mixed towards the middle of the nineteenth century. When photography became available as a visualisation technology, physicians publishing on skin diseases happily integrated the technology to fit in with existing ways of depicting diseased skin.

With the emergence of pathological anatomy, important changes in the study and understanding of skin diseases had taken place. New microscopical findings on the skin, as discussed in chapter three, were used to explain skin diseases at a tissue level. Physicians started to take the diseased tissues of the skin (skin glands, nerves, vessels, etc) into account when arranging skin diseases in classifications. ${ }^{50}$ Also, the interaction with other tissues in the rest of the body was taken to be important for the understanding of skin diseases. The work by Ferdinand von Hebra signifies the integration of general anatomical pathology into thinking about skin diseases. He applied the ideas of general pathology to the skin similarly to other organs. His masterpiece Atlas der Hautkrankheiten appeared in several parts, containing impressive coloured lithographed plates, between 1856 and $1876 .{ }^{51}$ Hebra compared the atlas with a 'clinic of skin diseases', where the illustrations replaced the patients. As he focused on the clinical representation of patients with skin diseases, the evidence of the clinical view of the patient was the basis for diagnosis and treatment. As in most works on skin diseases from the middle of the nineteenth century, Hebra's depictions both emphasised the typical morphology of the primary lesion (Willan) as well as the individualised patient in whom the disease occurred. In the pathological clinical tradition, with bedside observation of the patient as its starting point, patients were depicted as individual cases carrying typical lesions.

The authors of early photographic works on skin diseases each found a way to continue the mixture between the depiction of abstract morphology and clinical cases. 


\section{Chapter 5}

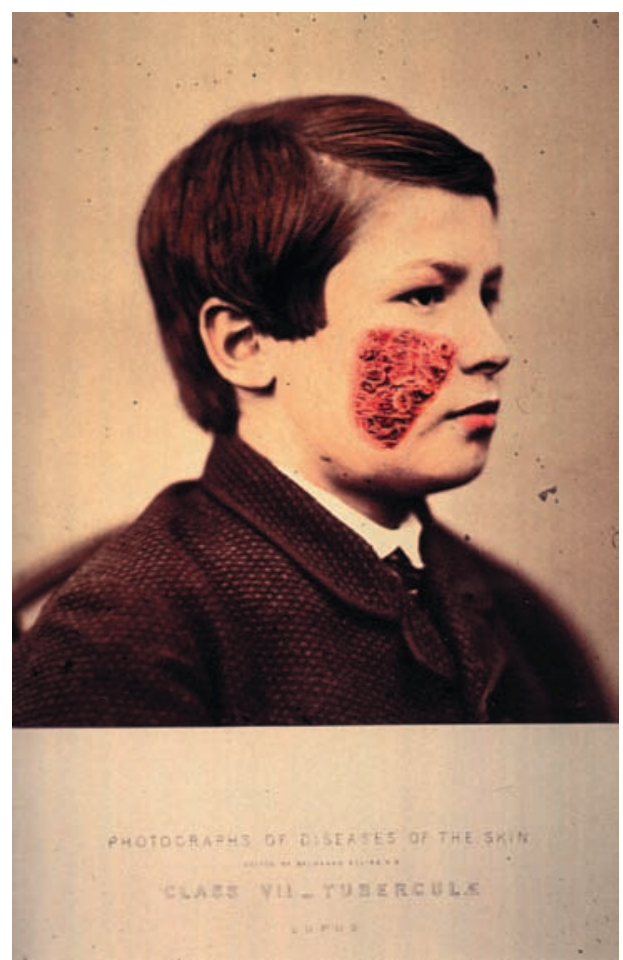

Figure 5.4 'Class VII - Tuberculea.' In Squire's Photographs (coloured from life) of the diseases of the skin (1865). National Library of Medicine, US.

Classification and case histories were combined, but classification was subordinate to the clinical. This combination of cases and classification into types of diseases is very clear in Squire's Photographs (coloured from life) of the diseases of the skin. Each photograph represented one class of skin disease. To illustrate his 12 classes of skin diseases, Squire therefore needed to use 12 photographs. Squire's work shows a strong one-to-one link between photograph (case) and disease. The text with the pictures underlined this link. First, the name of the class and the specific illness represented appeared under each photograph (see figure 5.4: Class VII - Tuberculea). In addition, two pages of text accompanied each photograph. In the text Squire subsequently treated the disease, a general description of the disease, "Its situation", "Its varieties", "Treatment", the "History of the case", the "Present state" and "The photograph". As in previous publications on skin diseases, depiction was deeply intertwined with the classification of skin diseases. One image represented one disease. The Clinique photographique by Hardy and de Montméja shows a similar one-to-one relationship between skin diseases and photographs. Although Hardy proposed another type of classification inspired by Willan, the organisation of the book still linked one skin disease to a single photograph. In contrast to the work of Squire, Hardy and de Montméja did not include a case history of the patient depicted. The text accompanying 


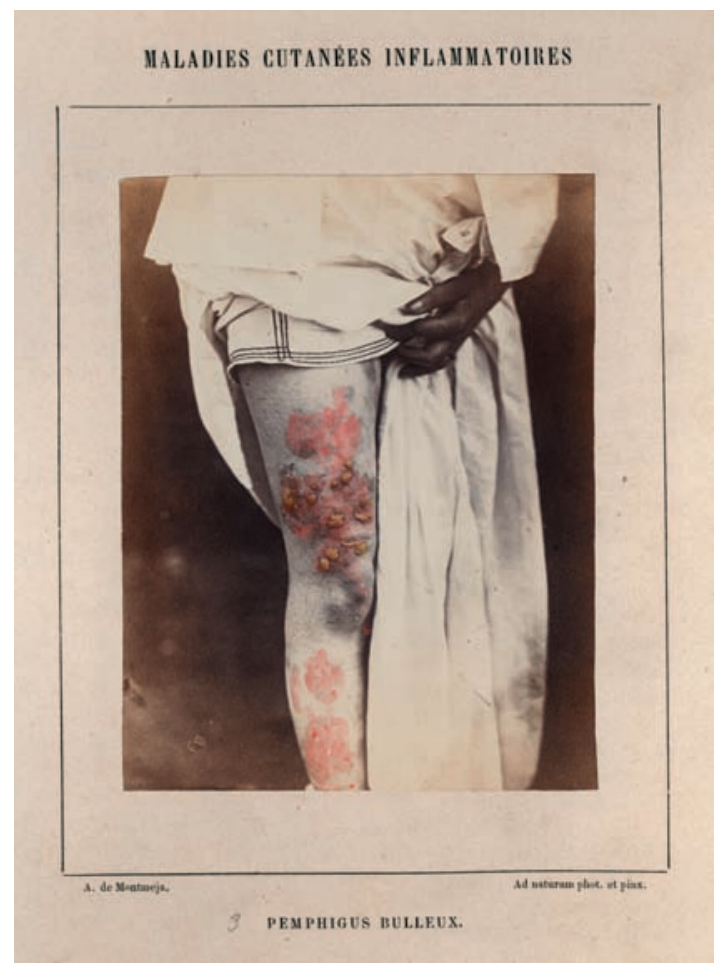

Figure 5.5 Patient revealing her affected skin. 'Pemphigus bulleux.' In Hardy, A., \& de Montméja, A. (1868). (C) BIUM Paris.

http://www.bium.univ-paris5.fr/histmed/medica/page?37462\&p=36

the photographs in Clinique photographique covered only general information about the disease concerned. Hardy discussed the characteristics, symptoms, course and treatment of the disease.

In the photographic works on skin diseases patients were presented by the authors as if the physician were lecturing at the patient's bedside. As the name of Hardy's work suggests, the Clinique photographique functioned as a photographical clinic - a virtual pictorial hospital clinic where the patient was substituted by a photograph. Information about the specific case contributed to creating a clinical situation. Both Fox and Squire included information about the case depicted in the accompanying text. Squire introduced the photographed patient as a specific case with its own history. For the photograph in figure 5.4 the history started as follows: "The portrait is that of a boy of lymphatic temperament, aged 12 , in whom the affliction had existed for eight years". ${ }^{52}$ The typical of the disease was thus situated in the specificity of the case..$^{53}$ In the atlas by Fox a similar relationship between the typical and the specificity of the case was created.

52 Squire (1865), Text to Class VII-Tuberculae, History of the case.

53 Historians of science Lorraine Daston and Peter Galison referred to the 'characteristic' atlas, where the image locates the typical in an individual. See: Daston, L., \& Galison, P. (1992). The image of objectivity. Representations(40), 81-128. 


\section{Chapter 5}

The text next to each photograph consisted of three elements: synonyms for the disease, a description of the observation of the patient and a general description of the skin disease. A remarkable typographical difference between the text of the observation of the case (small print) and the general part on the disease (normal large font) emphasised the need for cases to learn about a disease. The case text with Acne in Fox reads:

\footnotetext{
Case-C.R., aet. 20, U.S. A case contrasting strongly with the foregoing one. The patient was of fair complexion, with a naturally delicate skin. He suffered from dyspepsia, but in other respects was strong and well. The cheeks were hyperaemic and nearly covered with dark-red papules and pustules. ${ }^{54}$
}

As if standing beside the bed of the patient, explaining the history of the case to his students or his colleagues, Fox introduced the story with the photographic plate. By subsequently connecting the case history with general information on the disease, Fox continued his clinical lesson in the atlas. References to other well-known dermatologists such as Hebra locate the case in a broader dermatological context. ${ }^{55}$ This provided the individual case with a meaning and authority exceeding the incidental account, which is a crucial part of the clinical lesson.

Existing conventions in pictorial make-up were continued in dermatological photography as well. The visual abstraction of the skin in small pieces can be seen from the beginning of the nineteenth century in atlases of skin diseases. Photographers of patients with skin diseases also focused on the particular afflicted locality of the skin. This kind of 'topical photography' resulted in photographs of hands, arms, legs, backs, abdomens, scalps and other parts of the body where the integrity of the skin was interrupted by a lesion. Half of the photographs in Squire's atlas fit this topical or local characterisation. About one third of the work by Hardy consisted of photographs of this kind, while the atlas by Fox was two thirds topical photographs. This attention to the local lesion seems a typical consequence of the preference or specificity of the disease for one specific area. For the depiction of eczema of the hands, or the illustration of acne, or the representation of the syphilitic chancre, the photograph seems dictated by the topical appearance of the disease. Ever since the Willanist systematisation of dermatology according to primary lesions, the attention of the physician had been directed towards the local in the observation and treatment of skin diseases.

One important aspect that distinguishes the later topical photographic depiction of the skin from the earlier dermatological illustrations is the role of the patient. In the lithographic or engraved atlases of skin diseases the patient is depicted as a passive person. In the photographs of skin diseases, however, patients often 'showed' the affected parts explicitly. A woman holding up her skirt or a man folding his hands so the camera can record the marked skin reveal more active patients (see example in figure 5.5). Yet these positions were most probably directed or controlled by the photographer or physician. 
As such the patient showing his or her affection signifies how, in a clinical setting, the image takes on a function of a dialogical didactic instrument between physician and patient, between student and teacher.

The authors of the photographic works on skin diseases appropriated photography to fit in with the existing ways of depicting diseased skin. However, photography also introduced new challenges in visualisation. How were you to keep the specifics of the colour of the skin lesions when the mechanical photographic process produced black and white pictures? Had artists become obsolete for depiction? How did physicians make the most of the advantages of photography as a new visualisation technology? In the next section I show how the appropriation of photography took place in a transitional hybrid practice of depiction. Photography did not cause a sudden rupture in the depiction of diseased skin, but its appropriation was rather hybrid.

\title{
Artist and machine: 'la nature prise sur le fait'
}

\begin{abstract}
L'Iconographie photographique des maladies de la Peau, par le Dr G. H. Fox, a obtenu en Amérique un grand et légitime succès, grâce à la haute valeur scientifique et artistique des planches photographique. ${ }^{56}$
\end{abstract}

The translator of the American atlas Photographic illustrations of skin diseases attributed the success of the work to the high "scientific" and "artistic" value of the photographic plates. Early photographic atlases of skin diseases resulted from hybrid production practices. Mechanical illustration processes seemed to merge with manual colouring without any problem. In contrast to lithographic illustrations, the artist was no longer involved in the delineation of the drawing. However, his skills were still in demand for the much-needed colouring of the photographs. Taken as an unproblematic practice to the authors themselves, the colouring reveals exactly part of the transition that was taking place in the appropriation of photography for the depiction of skin diseases.

Colours were essential for dermatological photographs. Without colours the photographs were of no use for learning to recognise diseases in reality. However accurate the photographs were deemed to be, the lifelikeness of the pictures was just as valuable. In the preface to Clinique photographique Hardy pointed to the importance of colour for diagnosing skin diseases. ${ }^{57}$ Because the atlases were expected to fulfil a role as clinical aid for physicians in daily practice, the photographs needed to resemble the clinical case of the patient as much as possible. Indeed, in his preface Fox called colour an "essential element of diagnosis". ${ }^{8} \mathrm{He}$ even criticised previous photographs for their disfigurement by "careless daubing", which referred to sloppy colouring with paint. Apparently,

56 J.B. Holman in: Fox, G. H. (1882), Avant-propos du traducteur.

57 Hardy, A., \& de Montméja, A. (1868), Préface, A. Hardy, p. I: "le diagnostic s’établit ordinairement d'après une certaine nuance de coloration".

58 Fox (1880), preface. 


\section{Chapter 5}

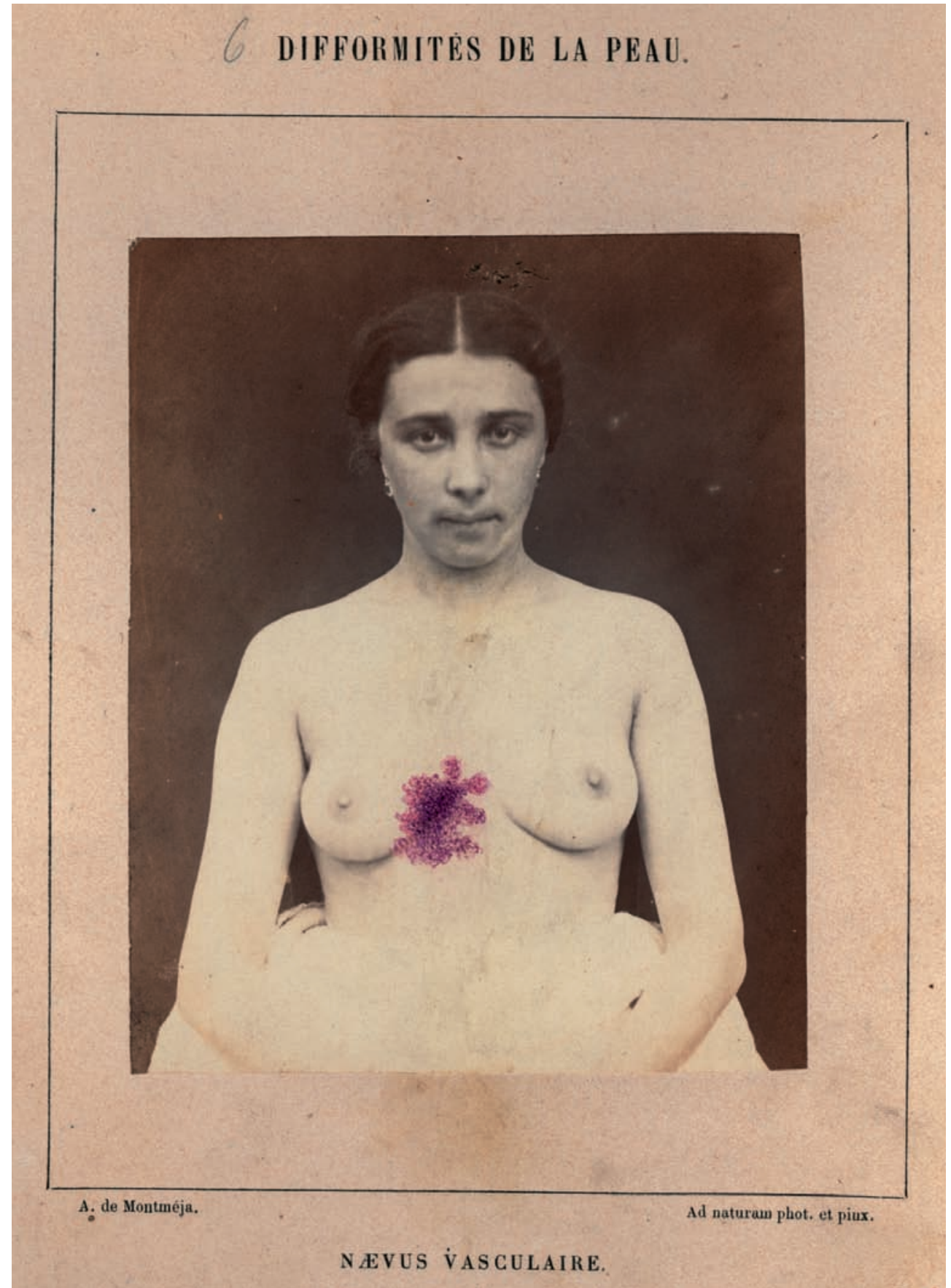

Figure 5.6 Differences in colouring.

Left: 'Naevus vasculaire'. In Hardy, A., \& de Montméja, A. (1868). (C) BIUM Paris. http://www.bium.univ-paris5.fr/histmed/medica/page?37462\&p=27

Right: 'Favus'. In Squire, A. B. (1865). Photographs (coloured from life) of the diseases of the skin. National Library of Medicine, US. 


\section{The colours of life}

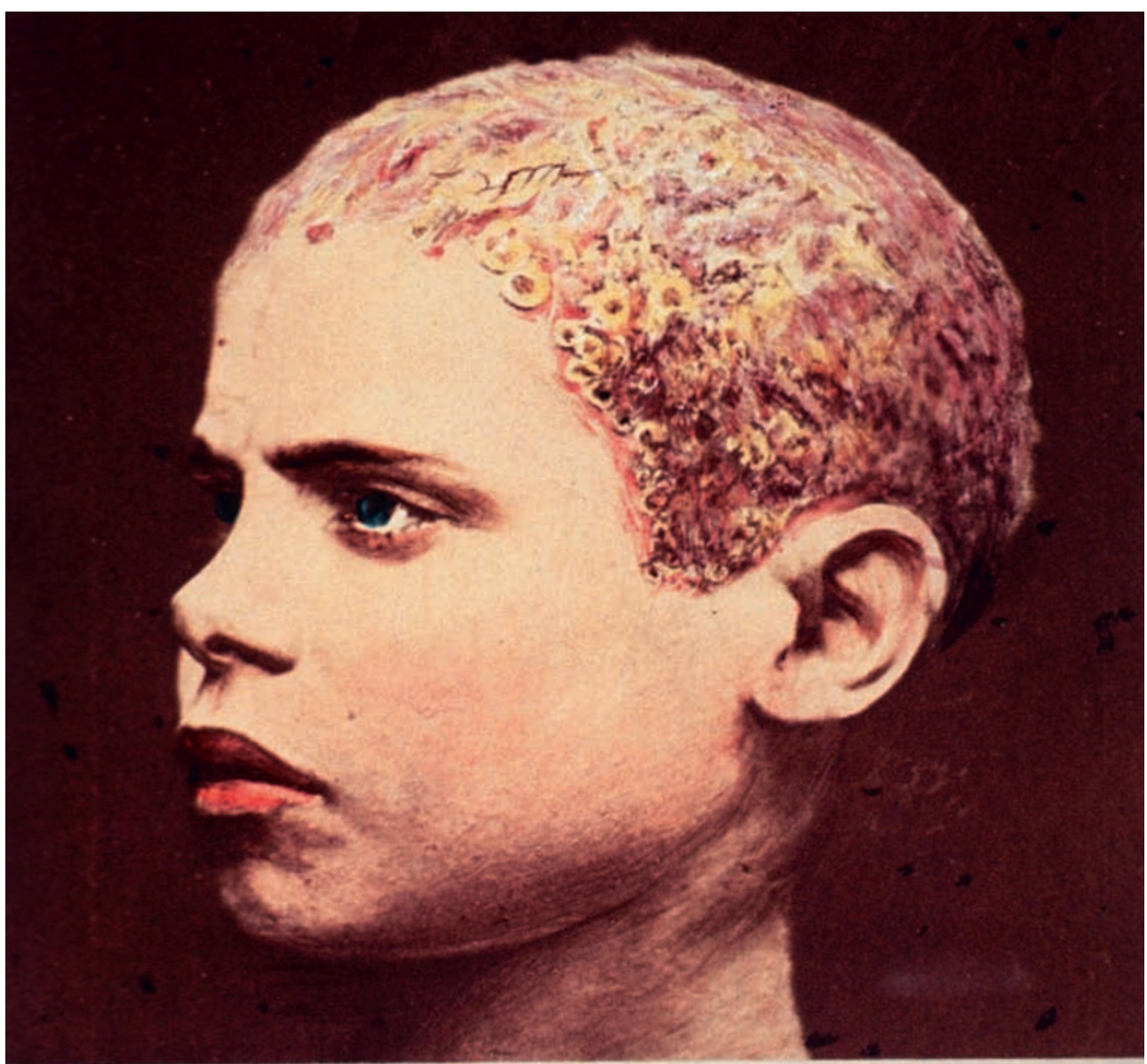

PHOTOCRAPHS OF DISEASES OF THE SKIN

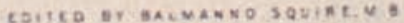

CLASS VI-VEGETABLE PARASITE DISEASES

$$
\begin{aligned}
& \text { (OF THE SCALP) } \\
& \text { FA } \vee \cup S .
\end{aligned}
$$




\section{Chapter 5}

colouring required some special skills to result in high-quality coloured photographs. As a diagnostic aid, the colouring in the photographic atlases was important as a visual pointer in the photographs. ${ }^{59}$ In the works of both Hardy and Fox only the lesion was highlighted with a mixture of watercolours. Nuances of blue, red, pink and greens highlighted the affected parts of the skin in the photographs and directed the observer towards the diseased area. This selective way of hand-colouring photographs of skin diseases was also present in the work of Squire. The artist who coloured the photographs in Squire's work, however, coloured other parts of the image as well, such as the lips or eyes of the patient, for example (see figure 5.6).

Colours intensified the link between the realistic case of the patient and the photographs. To represent the skin disease in the patient with the utmost fidelity, the photographs had to be coloured "from life". Both Fox and Squire underlined the importance of colour for the "lifelikeness" of the illustrations. The subtitle of the work by Fox read "Forty-eight Plates from Life colored by hand", while Squire even implemented "coloured from life" in his main title. Hardy and De Montméja also followed this naturalistic approach for the faithful representation of diseases:

La partie artistique de cette œuvre, et sans contredit la plus importante, a été confiée à un de mes élèves, M. de Montméja, qui joint à une connaissance approfondie des maladies de la peau un talent incontestable de photographe et de coloriste; nous pouvons dire que ses planches représentent la nature prise sur le fait. ${ }^{60}$

Hardy not only praised de Montméja's skills in colouring, but the photographic quality of the plates as well.

The existing pictorial convention of naturalism in colouring was blended in with photographic technology. With the combination of photographic (mechanical) accuracy and colouring by the artist, the authors joined the best of two worlds. Fox referred to the merger of photography and artistry when he expressed his aim of the atlas: to represent features of skin diseases "with photographical accuracy and to employ colour with the utmost care to render the illustrations as life-like as possible". ${ }^{61}$ A figure on the title page of his work similarly shows the intertwined relationship between photography and colouring: the word 'Skin Diseases' appears amidst a photo-camera with the text ' 60 cases' on one side and a painter's palette with the text 'from life' on the other. In the work by Hardy and de Montméja, the heterogeneous production of the photographs manifested itself in the expression 'A. de Montméja. Ad naturam phot. et pinx.' (photographed and painted after nature) below each photograph. Art historian Martin Kemp argued that this line indicates "an emulation of the great tradition of draughtsmen and print makers who boasted that they portrayed things 'from life'." ${ }^{2}$ Even more striking though

59 Art historian Martin Kemp used the term 'visual pointing' in his discussion on the use of colour in Hardy's Clinique photographique, see: Kemp, M. (1997), p. 148.

60 Hardy, A., \& de Montméja, A. (1868), Préface p. I.

61 Fox, G.H. (1880), preface.

62 Kemp, M. (1997), p. 148. 
is the seemingly smooth merger of photography with these older painting traditions as compatible techniques of illustration.

Yet was photography not dictated by an ideal of objectivity precisely because it eliminated the subjective interpretation by the artist? The use of photography in science and medicine in the nineteenth century has been connected to objectivity in historical studies. ${ }^{63}$ According to medical historian Holger Maehle, the supposed objective representation of reality was the main argument for the use of photography in early medical books and articles with photographic illustrations. ${ }^{64}$ For photomicrography (photography of microscopic specimens) in particular the objectivity of photography became an important issue. Subjective ideas by the artist influencing the drawings could now be circumvented. Maehle shows how in bacteriology in particular photographs were seen as evidence and an objective means of scientific communication. ${ }^{65}$ However, after initial enthusiasm for photography in microscopical studies, problems with optical artefacts and the retouching of photographs urged photomicrographers to reconsider and qualify the claim for objectivity towards the end of the nineteenth century. ${ }^{66}$ Maehle also indicates that objectivity was not the primary driving force for clinical photographs, which were mostly used as didactic sources. ${ }^{67}$ For the authors of the photographic atlases of skin diseases, a similar lack of importance existed for the objectivity of the photographs. Artistic skill was not considered a hindrance but a necessary ingredient for lifelike coloured photographs.

The hand-coloured photographs in early atlases of skin diseases demonstrate the slow and subtle transition from artistic illustration techniques to mechanical visualisation processes. With the introduction of photography for the medical depiction of skin there was still room for the artist. However, the artist was not entirely free in his interpretation of the colouring. Artistry became subjected to the restrictions of expertise. Colouring was either performed under the surveillance of an expert on skin diseases or the colour had to be applied by somebody with knowledge of skin diseases. In the Clinique photographique De Montméja indicated that the colouring of the photographs was executed under his watchful eye. Moreover, his master Hardy judged the work in the last resort. ${ }^{68}$ Fox wrote in his atlas that Joseph Geartner, the artist who was responsible for colouring his photographs, had formerly been a physician who studied skin diseases at the hospital of the great dermatologist Hebra in Vienna. ${ }^{69}$ Artistic skills and dermatological knowledge came together in a painter's pencil.

Hand-colouring of photographs was not an uncommon practice in popular photography. The carte de visite, an industrially produced photographic portrait in a

63 See Maehle, A. H. (1993). For further reading on scientific objectivity see for example: Daston, L. (2001). Scientific objectivity with and without words. In P. Becker \& W. Clark (Eds.), Little tools of knowledge (pp. 259-284). An Arbor: The University of Michigan Press.

64 Maehle, A. H. (1993), p. 568.

65 Ibid., p. 569.

66 Ibid., p. 571.

67 Ibid., p. 572.

68 Hardy, A., \& de Montméja, A. (1868), Préface, A. de Montméja, p. III: "Le coloris, confié à des mains habiles, s'exécute entièrement sous mes yeux, avec la sanction de M. Hardy, qui juge en dernier ressort."

69 Fox, G.H. (1880), preface. 


\section{Chapter 5}

card size form, became an extremely popular medium for the circulation of celebrity pictures in France, Britain and America during the 1860s. These photographic portraits on cards were often coloured. In The silver sunbeam (1864), a practical and theoretical textbook on photographic printing, American author and medical doctor John Towler ${ }^{70}$ included an extensive account of ways to colour the 'card-picture' ${ }^{71} \mathrm{He}$ stated how "the colors required to tint or color photographs are the same as those employed in miniature painting, and the same amount of artistic skill is required in the one as in the other" ${ }^{72}$ Towler mentioned the use of 'Naples yellow', 'sap green', 'Prussian blue', 'rose madder' and 'burnt sienna'. ${ }^{73}$ He then explained how to use these colours to paint the face, the hair (blonde, chestnut, black, grey, red and white hair) and different kinds of drapery. His extensive instructions on colouring reveal the amount of skill involved in the use of colour in photographs. A similar level of skill must have been required for the colouring of the dermatological photographs in atlases.

However, apart from artistic abilities, other non-medical specialist skills and knowledge were initially needed for the use of photography to depict skin diseases. For the actual photographic skills some physicians at first had to resort to professional photographers to take the pictures of the patients. With the advent of photographical practices in medicine, popular conventions of photography also had a notable effect on the ways of depicting patients with skin diseases.

\section{Popular photographic conventions}

In his reminiscences the American dermatologist George Fox recalled how he developed an interest in medical photography after he took a patient to the studio of a local photographer:

At the Northwestern Dispensary I first became interested in medical photography. An old patient with white hair and an epithelioma involving the whole lower lip presented such a striking picture that I took him to a photographer on Eighth Avenue and had a dozen card photographs made. Other patients with striking forms of skin disease were next photographed and soon I found I had quite a collection with a large pile of extra prints and was spending hours at E.K. Hough's photographic studio $(\ldots) .^{74}$

Fox probably remembered how the photograph in plate XXXVIII in Photographic illustrations of skin diseases was made. This particular photograph was very much

70 It is interesting to notice that Towler, a well-known writer on the early photography, was also dean of faculty at the Geneva Medical College in New York. See: Burns, S. B. (1979b). Early medical photography in America (18391883). II. Physicians and early photography. New York State Journal of Medicine, 79(6), 943-947.

71 Towler, J. (1864). The silver sunbeam. New York: Joseph H. Ladd. This work was very popular. It went through nine editions and was translated into three languages, see: Burns, S. B. (1979b), p. 947.

72 Ibid. Chapter XXXV.

73 Idem.

74 Fox, G. H. (1926). Reminiscences. New York: Medical Life Press, pp. 158-159. 


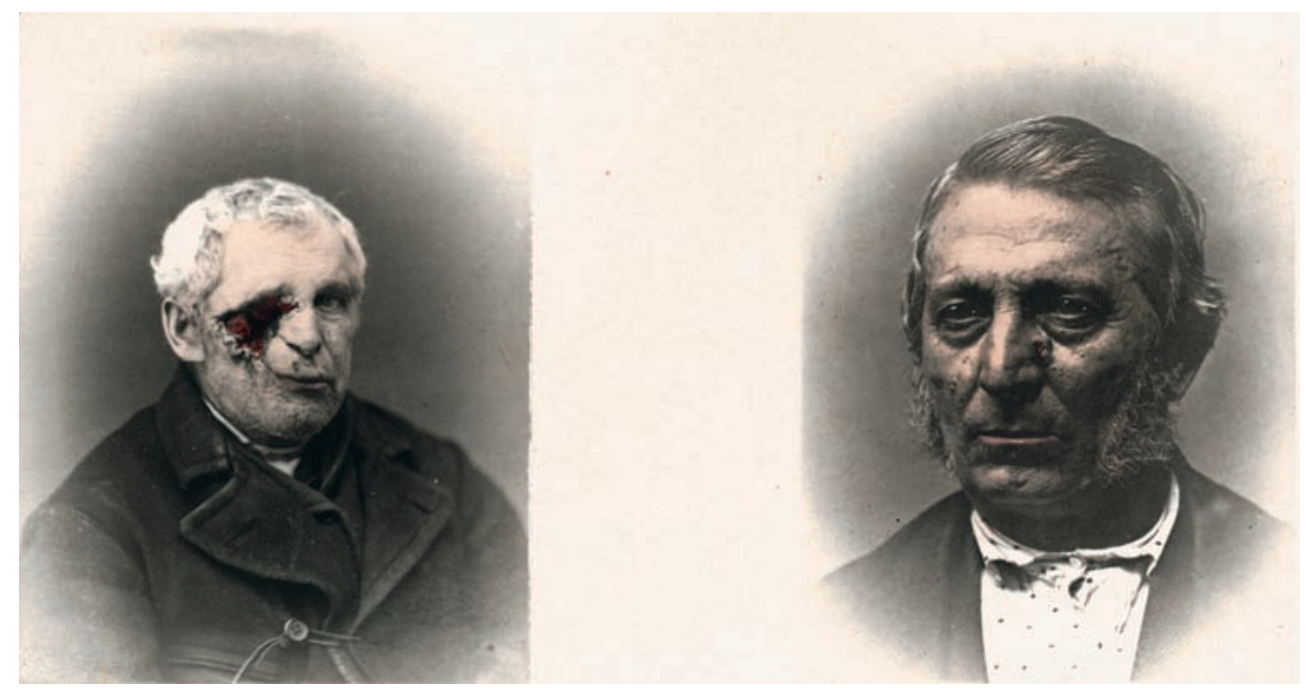

Figure 5.7 Portrait convention in depicting skin diseases. 'Epithélioma.' In Fox, G. H. (1882). Library Universiteit van Amsterdam.

influenced by contemporary portrait photography. In the local photographic studio the patient had apparently been positioned as if his portrait were to be taken (see figure 5.7). Dermatological photographs thus came to bear the mark of the popular photographic conventions of the time. The positioning of the sitter, the framing of the scene and the background all show how changes were taking place in the depiction of patients with skin diseases.

Physicians often relied on professional photographers to take their photographs. In Britain and America in particular the photography of patients was mostly initiated by individual doctors. ${ }^{75}$ Physicians either took the pictures themselves or they took their patients to the local portrait photographer. ${ }^{76}$ American medical photography in particular emerged in close relation to popular portrait photography. Many physicians used the popular daguerrean images for medical consultations, clinical records and publication. ${ }^{77}$ Historians Fox and Lawrence have argued that in the American and British contexts conventions in early medical photography were similar to those in paintings and drawings of portraits and domestic scenes. ${ }^{78}$ Early medical photographs were very much like images depicting everyday life, according to Fox and Lawrence: "Pictures of doctors and of patients looked much like contemporary portraits" ${ }^{79}$

Physicians did not necessarily visit the same photographer to produce their pictures.

76 See Hansell, P. (1959).

77 Burns, S. B. (1979c). On the popularity of daguerreotypes in the United States see for example: Southworth, A. S. (1871). The early history of photography in the United States. The British Journal of Photography, 18, 530-532.

78 Fox, D. M. \& Lawrence, C. (1988), p. 9.

79 Ibid., p. 21. 
The photographic atlas by Fox, for example, contains many photographs of different styles. His atlas contained a collection of photographs of striking cases of skin diseases he had assembled over a period of time. Several photographs were taken from patients who visited medical centres in Fox's home town of New York, while other photographs were sent to him by dermatologists outside New York. In the case histories Fox indicates that the patients attended various medical centres, such as the Women's Medical College, the New York dispensary, the New York Dermatological Society and the Bellevue Hospital in New York. As far as we know, photographer Oscar G. Mason took many of the photographs in the atlas by Fox. After a career as a daguerreotypist, Mason would go on to become one of the first American photographers to specialise in medical photography. Between 1869 and 1909 he was in charge of the photographic department at the Bellevue Hospital in New York. Apart from Mason, however, many other photographers (and physicians) seem to have been involved in the production of the images in Fox's atlas.

Popular photographers sometimes put studio requisites to use. Several photographs in the atlas by Fox clearly show how the photographer used common studio devices to stage the scene. Patients leaned against a pillar and children played with toys to keep them quiet (see figure 5.8 left). Chairs were also often used to make the patient hold certain poses (see figure 5.8 right). The use of these props suggests how the making of photographs differed from other illustration techniques. Instead of the artist, now it was the habits of the photographer, his studio and his conventions that came into play for the depiction of skin diseases. With the inclusion of photographical practices in the depiction of skin diseases, new pictorial conventions were included as well.

Early dermatological photography was very much influenced by portrait photography. ${ }^{80}$ Like several photographs in Photographic illustrations of skin diseases, some of the patients in Squire's 12 hand-coloured photographs were staged as sitters for portraits. It is not known if Squire took the photographs himself or if he took his patients to the studio of a professional photographer. Yet in his descriptions Squire himself often referred to the photographs as portraits: "The portrait is that of a man aged 20, who first noticed the eruption about twelve weeks before he came under the author's care." ${ }^{81}$ To Squire the photographs were portraits of patients, representing the features and characteristics of particular diseases as well as the temperament of the sitter. For a present-day audience, one of the most eye-catching aspects of the portrait-like albumens of skin diseases from the 1860s to the 1880s are the inscriptions of the social background of the persons portrayed. The sitters give away their social status through their clothing, headwear, jewellery and specific hairdos (see figure 5.9). The photographs in the work by Squire display a mix between the exposure of individuals and diseases in portraits. This was no coincidence, as photographic portraiture had reached a peak in the middle of the nineteenth century.

In the big cities of New York, London and Paris the number of photographic studios

80 Portrait-like photography of patients was not confined to dermatology. For examples in other disciplines see figure 2-4 in: Amirault, C. (1993). Posing the subject of early medical photography. Discourse, 16(2), 51-76.

81 Squire (1865), text to Class VIII Syphilidae. 
was multiplying at an enormous rate in the 1850s. Photography was used for portraiture from its birth. ${ }^{82}$ Art historian John Tagg has shown how the history and growth of photography, and especially the photographic portrait, was embedded in a demand of social classes claiming their presence in pictures:

The history of photography is (...) a history of needs alternatively manufactured and satisfied by an unlimited flow of commodities; a model of capitalist growth in the nineteenth century. Nowhere is this more evident than in the rise of the photographic portrait which belongs to a particular stage of social evolution: the rise of the middle and lower-middle classes towards greater social, economic and political importance. ${ }^{83}$

Photographer Gisèle Freund has similarly argued that the photographic portrait was the last step in a process of mechanisation of the portrait. She placed the photographic portrait in the development of portraiture as a social structure, a "cult of individualism", which started in the late eighteenth century. ${ }^{84}$ From the 1840 s the daguerreotype portraits ruled the ever-growing market of the portrait. Mechanical improvements made it possible for almost every social class to have their likeness taken. ${ }^{85}$ The introduction of the collodion or wet-plate process in 1851, however, heralded a new chapter in photography. Now photographic printing was more accessible to amateurs and the carte de visite became a very popular medium for the circulation of celebrity portraits. The heroes of the age, such as Queen Victoria and famous actors, were circulating as mass products among the public. By this time photographic processes were functioning as ways to "record and transmit socially important information about individuals" and so they played a crucial part in "emergent ideas about individuality, personality and character", as historian Peter Hamilton has shown. ${ }^{86}$ The photographic portrait had become a medium that inscribed both individuals and their social identity. ${ }^{87}$

Early photographs of patients with skin diseases were consistent with the conventions of the photographic portrait. Several portraits in the American atlas Photographic illustrations of skin diseases very closely resemble images from an album of cartes de visite. ${ }^{88}$ Like the sitters in other portraits, a number of patients in the atlas by Fox and almost all the patients in the work by Squire assumed a pose for a portrait: head and shoulders visible, the upper body half turned towards the camera.

The face was very important in both portrait photography and early medical

82 On photographic portraiture see: Freund, G. (2004). Precursors of the photographic portrait. In V. R. Schwartz \& J. Przyblyski (Eds.), The nineteenth-century visual culture reader (pp. 79-82). New York, NY: Routledge; Tagg, J. (1988), chapter 1: A democracy of the image: Photographic portraiture and commodity production; and Rosenblum, N. (1997). A world history of photography (3rd ed.). New York: Abbeville, chapter 2: A plentitude of portraits 1839-1890.

83 Tagg, J. (1988), p. 37.

84 Freund, G. (2004) in V. R. Schwartz \& J. Przyblyski (Eds.), p. 80.

85 Tagg, J. (1988), p. 43.

86 Hamilton, P., \& Hargreaves, R. (2001). The beautiful and the damned: The creation of identity in nineteenth century photography. Aldershot: Lund Humphries London in association with the National Portrait Gallery, p. 115.

87 Tagg, J. (1988), p. 37.

88 Compare portraits in figure 9 to images in Tagg, J. (1988), p. 49. 


\section{Chapter 5}
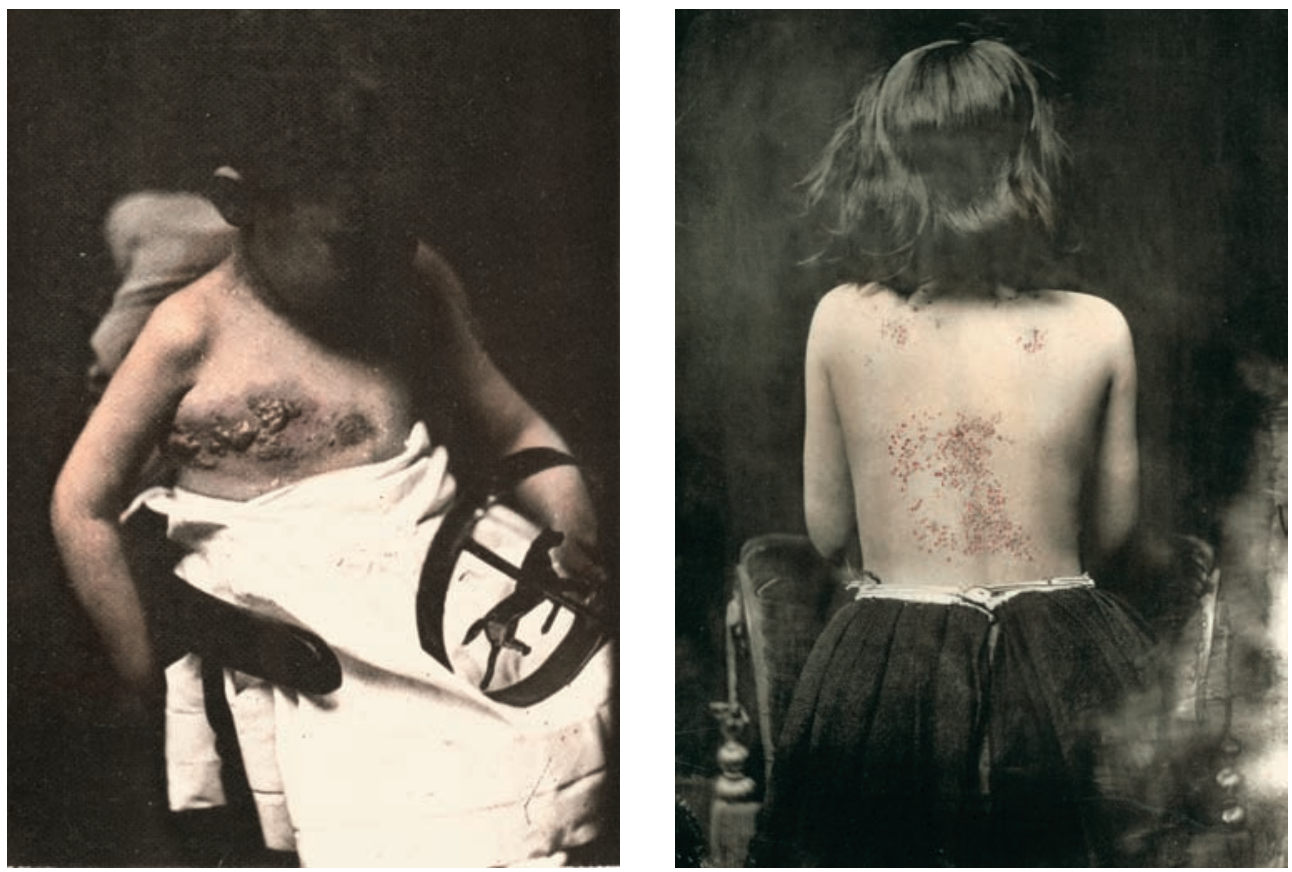

Figure 5.8 Use of props in medical photography. Left 'Zona' and right 'Eczéma.' In Fox, G. H. (1882). Library Universiteit van Amsterdam.

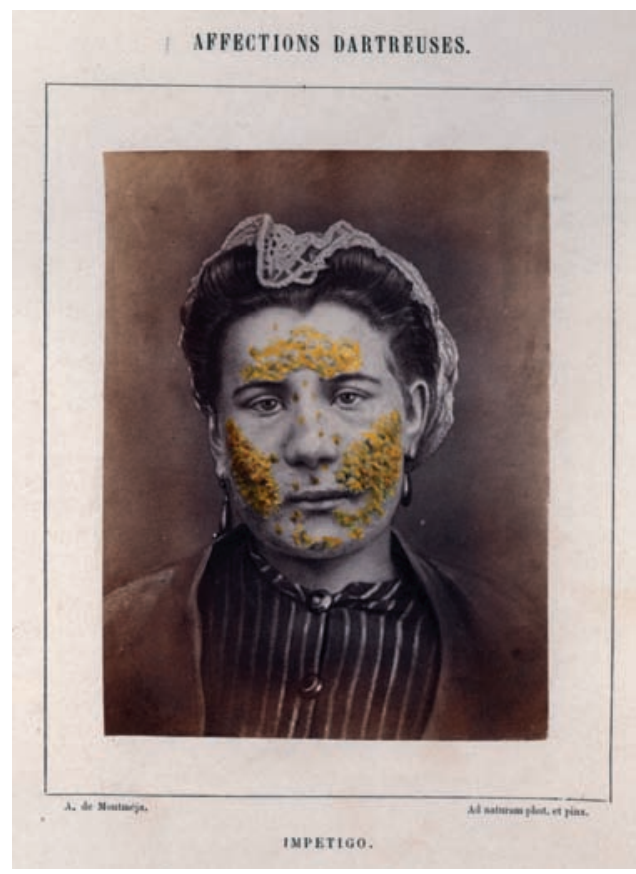

Figure 5.9 Example of clothing and jewellery in medical photographs. 'Impetigo'. In Hardy, A., \& de Montméja, A. (1868). (C) BIUM Paris.

http://www.bium.univ-paris5.fr/histmed/medica/page?37462\&p=76 
scientific photography. As the science of reading the signs of the face, physiognomy was a well-known subject of early medical scientific photography. Anthropologists used photography to study key visual characteristics of ethnic types and races, while physiognomist Francis Galton studied photographs to distinguish visual typologies in faces. ${ }^{89}$ In the 1870 s and 1880 s Galton used photographs for his "pictorial statistics" to support his theory of 'eugenics'. In medicine the face was the focus of attention in early psychiatric photography by Diamond and Duchenne. ${ }^{90}$ These photographic practices were each focused on the identification of outward visual expressions manifesting in the face and head as indicators of 'inner' character and constitution. Physiognomy was also important for Squire. He deduced the constitution of some of his patients from the photographs. Certain types of skin diseases were linked to specific constitutions of the patients. In the text to Class V - Vegetable Parasite Diseases: Cloasma, Squire wrote how the "patient's tendency to consumption may be inferred from her features and complexion, as well as from her long narrow thorax and small 'costal angle". ${ }^{91}$ Likewise, the temperament of a four-year-old boy with Impetigo showed itself in the photograph: "The photograph enables many of the details of the disease to be fairly studied. (...) The lymphatic temperament of the patient is indicated by the pastiness and fairness of his complexion, and by the clumsy build of his features". ${ }^{92}$ By reading body and skin in the photograph, Squire was able to make a link between the outward signs and the inner background of the disease. ${ }^{93}$ As in portraiture, the face was an important part in some of the dermatological photographs.

The display of patients in portrait-like photographs put emphasis on the patients as persons. Whether intended or not, the patient's social information and character could now also be read in the pictures. This entwinement between popular conventions of portraiture with medical depiction did not pass by unnoted. Dermatologists had to find a way of dealing with the new popular conventions of photography to fit them to their requirements for medical depiction of skin diseases. In a time of increasing spread and duplication of photographs, the newly found way to depict patients became contested.

\section{Violating the sanctity of the person: dissemination and decency}

The American dermatologist Fox used his photographs of patients with skin diseases in talks he gave to medical societies in the United States and Canada. One day, after one of his lectures, the operator of the lantern-slide projector came up to him and said: "Say, Doctor! One of those women's faces shown on the screen was the very image of my

89 Kemp, M. (1997), p. 128-136. See also: Sekula, A. (1989).

90 On the scientific study of the face see for example Hamilton, P., \& Hargreaves, R. (2001), p. 57-107.

91 Quote from the text with Class VI - Vegetable Parasite Diseases, Cloasma. In: Squire (1865).

92 Excerpt from text with Class II - Pustulae, Impetigo (figurate). In: Squire (1865).

93 The relation between pictures of skin diseases and physiognomy was not new. Historian Jacyna has shown that physiognomy played an important role in the iconography of Jean Louis Alibert at the start of the nineteenth century. See: Jacyna, L. S. (1998). 


\section{Chapter 5}

sister-in-law" ${ }^{94}$ Fox replied that "with so many people in the world it was not strange that some looked alike." But he felt quite uneasy because he "remembered that a picture of a private patient taken with the assurance that it was not intended for publication had somehow got into the collection of cases from [his] clinic and that this particular patient came from this very city" ${ }^{95}$ Fox was encountering some new inconveniences with the use of photographs that had not occurred before with pictures of skin diseases. As pictures of patients now resembled portraits, they became comparable for non-medical audiences to other kinds of pictures. Huge numbers of photographs were spreading rapidly at the end of the nineteenth century and pictures could be found anywhere in western countries. Where dermatologists merely wanted to keep permanent records of interesting and important cases of skin diseases, other people might judge otherwise about what was to be seen in the photographs. A problem of blurring boundaries between medical and popular depiction revealed itself.

Towards the end of the nineteenth century cheaper means for the reproduction of photographs were available and photographs became a widely disseminated commodity. After the introduction of the Kodak hand-held camera by George Eastman in 1888, amateur photography reached the form of a "craze". ${ }^{96}$ John Tagg has described how the Kodak was part of a technical and pictorial representational revolution in photography. The status of the photograph changed, as it was limitlessly reproduced in books, advertisements, magazines and newspapers. ${ }^{97}$ In this process the boundaries of photographical practices shifted:

Eastman originated not only a camera but also a radical reconception of the boundaries of photographic practice, and an industrial system and machinery for producing standardised materials in sufficient quantities to support it. With the slogan 'You Press the Button and We Do the Rest', the Kodak brought photography to millions through a fully industrialised process of production. ${ }^{98}$

For dermatologists it was now also easier to produce their own photographs. In 1887 the American dermatologist Henry Piffard presented a paper on dermatological photography to the New York Dermatological Society, which he co-founded in 1869. Piffard was a good friend of Henry Fox and served as professor of dermatology at the New York University College of Medicine. ${ }^{99}$ His paper on 'cutaneous photography' mainly explained how patients with skin diseases might be photographed by the dermatologist himself, inside his consulting room. ${ }^{100}$ By using a self-created instant flashlight made from magnesium, the dermatologist was no longer dependent on a professional photographer to take photographs. Piffard was convinced that patients would be more willing to be photographed in the privacy of the

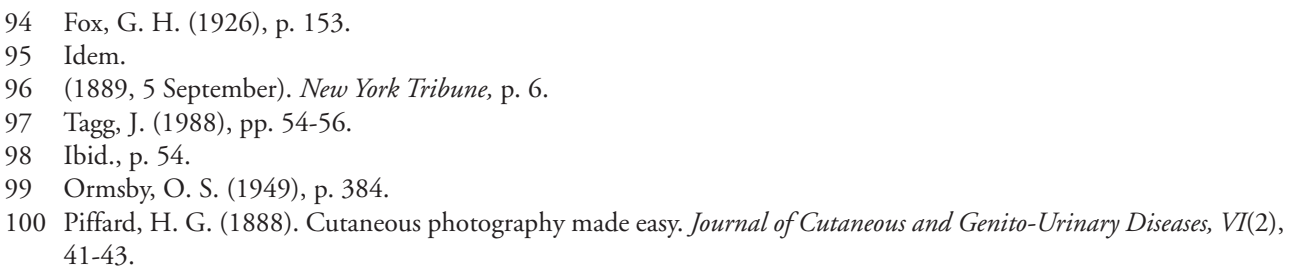


consulting room than in a studio of a professional photographer:

The desirability of keeping a permanent pictorial record of important and interesting cases of cutaneous disease is fully appreciated by every working dermatologist. (...) The chief obstacle has been the difficulty of securing in the consulting-room a sufficient and a proper distribution of the light, making it necessary in most cases to take the patient to the operating rooms of the professional photographer. To this many patients object. Even when they consent, an hour's time is lost for each negative secured. My purpose this evening is to bring to your notice a simple method, devised by myself, whereby these inconveniences may be reduced to the minimum. ${ }^{101}$

The dermatologist himself was therefore stimulated to put photography into use. Other physicians similarly encouraged doctors to cultivate photography as amateur photographers. ${ }^{102}$ In 1889 an American physician wrote that the use of magnesium flash powder and sensitive dry plates made it easy for anybody to produce photographs, including the physician: "In this way cases of facial paralysis, spinal curvature, hipjoint disease and marked skin disease, or any form of bodily deformity can be easily photographed by an instantaneous process and thus the best of all records be kept of them for future reference". ${ }^{103}$

In this new era of pictorial representation and amateur photography the photography of patients became the subject of fierce debate. Several articles in The New York Medical Journal in 1894 testify that some American physicians heavily criticised the use of photography in medicine. The advantages of photographs over other kinds of illustrations and drawings were questioned. Physicians argued for special attention to the moral limits in the use of photographs in a medical context. The discussion indeed signalled the need to demarcate medical photography from popular forms of photography. The main issue in the discussion was the popularity of photographs for medical illustration and the limits to that popularity. Photographs were used too often and patients were unnecessarily exposed. A letter to the editor of The New York Medical Journal stated that 'decency' required that

...even in medical publications, the scope of the photograph should be confined to the parts in which the phenomenon noted occurs; that the rest of the body, being unnecessary to the demonstration, be left out of the field, or be suitably covered up? ${ }^{104}$

The author, who called himself 'Medicus', claimed that physicians transgressed the limits of decency in fields such as obstetrics and gynaecology. In these fields exposure of the "obstetric region" was a necessary evil, but "other regions [should] be kept properly

101 Ibid., p. 41.

102 Reed, B. (1889). Why physicians should cultivate photography. The Medical Record, November 9, 514-515.

103 Ibid., p. 515.

104 Medicus. (1894). Letters to the editor: Indecency in photography. The New York Medical Journal, 59(June 9), 724725. Quoted on p. 724. 


\section{Chapter 5}

covered". ${ }^{105}$ According to the author, physicians would be guilty of indecency if "in photography they transgress these limitations" ${ }^{106}$ Photographs of unconscious women in compromising positions were offensive and objectionable to the author and he made a strong plea for the use of diagrams and texts to prevent the publication of these "repulsive photographic illustrations". ${ }^{107}$ The patients were in need of protection because the photograph was too 'honest' and real:

There is a personal flavor about the photograph which is absent in the drawing or the outline, since in these latter forms of representation only the regions necessary to explanation of the facts described need be faithful to the model. ${ }^{108}$

In this plea for decency in medical photography the author therefore explicitly demanded that limits be set on the use of photography in medicine in order to protect the integrity of the individual patient.

Yet this discussion was not only about unnecessary nudity in medical photographs. The protection of the identity and integrity of the patient was directly linked to complaints about the popularity of amateur photography and 'wrong' uses of photography in medicine. In an editorial in The New York Medical Journal reference was made to a "craze for photography in medical illustration" ${ }^{109}$ According to the editors, the simplicity of making photographs with the new Kodak apparatus tricked the physician into transgressing the norms of decency and privacy.

\footnotetext{
No medical man has the slightest right to take liberties with a patient, least of all without the patient's knowledge; yet this is what the photographic apparatus, reduced to the "you-press-thebutton-and-we-do-the-rest" stage, enables an inconsiderate person - we hesitate to say a ruthless one - to do, ney, tempts him to do. (...) Not that all these pictures, or even many of them, are objectionable on the score of indecency, for they are not; but they are or appear to be of such character as to be capable of revealing the patient's identity, which should always be avoided. (...) The sanctity of the person should never be violated save as a matter of necessity. This is no new dictum. The medical profession has always recognized and endorsed it, but thoughtlessness now and then allows the camera to beguile an individual into its infraction. ${ }^{110}$
}

Photography was too much and wrongly used by some physicians. They had degraded themselves, and with them the whole medical profession, to a level that was humiliating and shameful. Instead of taking photographs to illustrate clinical histories, the editors therefore advocated the use of sketches or drawings. In a response to the editorial and

105 Ibid., p. 725.

106 Idem.

107 Idem.

108 Idem.

109 Editorial: The craze for photography in medical illustration. (1894). The New York Medical Journal, 59(June 9), 721-722.

110 Ibid., p. 721. 


\section{The colours of life}
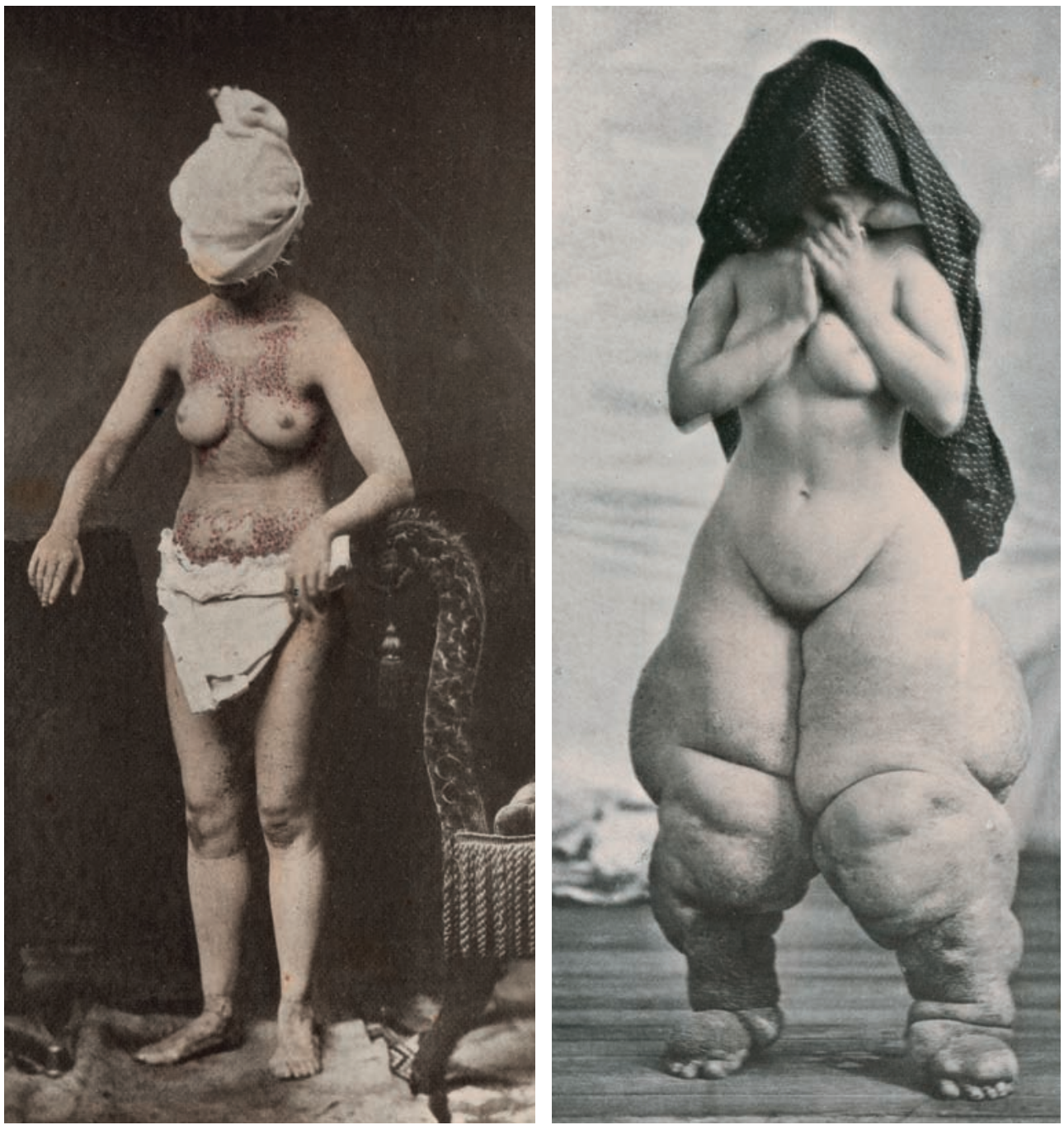

Figure 5.10 Anonymisation and covering of genitals as demarcation between professional and public depiction.

Left: 'Lichen Ruber.' In Fox, G. H. (1882). Right: 'Eléphantiasis.' In Fox, G. H. (1882). Library Universiteit van Amsterdam. 


\section{Chapter 5}

the previous letter, the Texan physician William Keiller later agreed that "the excellence and cheapness of the recent methods of reproducing photographs by photo-engravings has driven the majority of medical illustrators photo-mad". ${ }^{111}$

Moreover, there were fears that the circulation of medical photographs would stretch beyond the educated eye of the professional. Popular connotations with nudity in photographs, for example, could discredit the medical profession. In his letter the American physician Keiller emphasised how indecent nudity and unnecessary exposure of the person "which coming before the eyes of the laity are not calculated to raise the public estimation of professional delicacy". ${ }^{112}$ Associations with pornographic photographs or photographs of freaks was to be prevented at all costs. ${ }^{113}$ Monitoring the circulation of photographs for medical purposes was also necessary to ensure the protection of the patient. Surely, no patient wanted to become a celebrity, the editors of The New York Medical Journal argued: "The normal man and the normal woman shun the notoriety that comes from public exposure of the person, and nobody has the right to thrust such notoriety upon them". ${ }^{114}$

The call for limits to the use of photography in medicine resounded outside America as well. In an article on clinical photography in The British Medical Journal in 1895 reference was made to the importance of the patient and his individual rights. ${ }^{115}$ Despite all the advantages of keeping photographic clinical records of patients under treatment, managers of one London hospital had objected to this form of photography. A resolution was even adopted "to the effect that photographs should not be taken from patients of weak intellect" and that permission for photography should always be granted by the patient him/herself. ${ }^{116}$ The Lancet also reported on an incident in a London infirmary where the medical officer "had photographed a female patient of weak intellect in a nude state, and that thereby the friends of the patient were much incensed". ${ }^{117}$ The medical officer for his part tried to explain that the photograph was taken in the interest of science and that a nurse had been present. ${ }^{118}$ Again, the boundaries of medical photography and the protection of the patient were at stake. New limits of photography in medicine were taking shape.

The debate about medical photography at the end of the nineteenth century should be seen in a broader context of new attention to privacy. Medical historians have read the debate about decency in medical photography in various ways. ${ }^{119}$ Yet only if we acknowledge the link between developments in medical photography and in popular photography does the call for boundaries in medical photography (and dermatological

111 Keiller, W. (1894). Letters to the editor: The craze for photography in medical illustration. The New York Medical Journal, 59(Jun 23), 788-789.

112 Ibid., p. 788.

113 Reports of sales of 'indecent' photographs date back to the onset of photography. See for example: Indecent photographs. (1868). The Photographical Journal(June 16), 80.

114 Editorial: The craze for photography in medical illustration. (1894), p. 721.

115 Clinical photography. (1895). The British Medical Journal, I(June 22), 1402.

116 Idem.

117 The photographing of patients. (1895). The Lancet(July 13), 110.

118 Idem.

119 See Kemp, M. (1997), pp. 125-126; and Maehle, A. H. (1993), pp. 573-576. 
photography) become clear. Therefore, we have to turn briefly to the role of popular photography in the legal discussion of the right to privacy. The wide dissemination of photographs in particular played an important part in the desire to demarcate between public, private and professional practices of depiction.

A few years before the debate about medical photography attempts were made in America to delineate the right to privacy. In a groundbreaking article on the right to privacy in the Harvard Law Review (1890) two American lawyers pointed to the right of the individual "to be let alone". ${ }^{120}$ According to lawyers Warren and Brandeis, the new desire to define the boundaries between public and private was prompted by the invasions and dangers of new inventions and methods such as instantaneous photography and the popular press:

Instantaneous photographs and newspaper enterprise have invaded the sacred precincts of
private and domestic life. (...) For years there has been a feeling that the law must afford some
remedy for the unauthorized circulation of portraits of private persons; and the evil of the invasion
of privacy by the newspapers, long keenly felt, has been but recently discussed by an able writer. ${ }^{121}$

An important relationship was presented between the emergence of amateur photography and the right to privacy. The ability of people to make photographs anywhere, at any time, and of anybody, was accompanied by the ability of photographs to circulate among a wide audience. In his article 'Kodakers lying in wait' attorney Robert Mensel also noted how the cultural meanings of amateur photography were linked to the "evolution of the right of privacy in New York". ${ }^{122}$

As in the legal discourse, the debate about medical photography marked a call to demarcate professional clinical photography from public photography. In dermatological photography the emergence of specific pictorial conventions may now gain new meaning. The American atlas by George Fox in particular contains photographs that illustrate the desire to demarcate between professional and public. The anonymisation of several patients shows that in dermatological photographs in particular the protection of the identity of the patient was an emerging convention (see figure 5.10 and 5.11). The stigmatising nature of the two diseases for the women in figures 5.10 may have caused the photographer and/or the physician to protect their privacy by masking their faces. At the same time the dermatologists publishing these photographs in their works could not be accused of indecency in any way. These two examples of photographs with anonymised patients belong to the earliest attempts in medical history to conceal the identity of the patient. Anonymisation is not seen in other kinds of medical illustrations such as lithographs. The very convention of concealing the patient's identity for depiction is inherently linked to the appropriation of photography.

120 Warren, S. D., \& Brandeis, L. D. (1984). The right to privacy. [The implicit made explicit]. In F. D. Schoeman (Ed.), Philosophical dimensions of privacy: An anthology (pp. 75-103). Cambridge: Cambridge University Press. (Original published in 1890, Harvard Law Review, IV(5).)

121 Ibid., p. 76.

122 Mensel, R. E. (1991). "Kodakers laying in the wait": Amateur photography and the right of privacy in New York. American Quarterly, 43(1), 24-45. Quote p. 25. 


\section{Chapter 5}

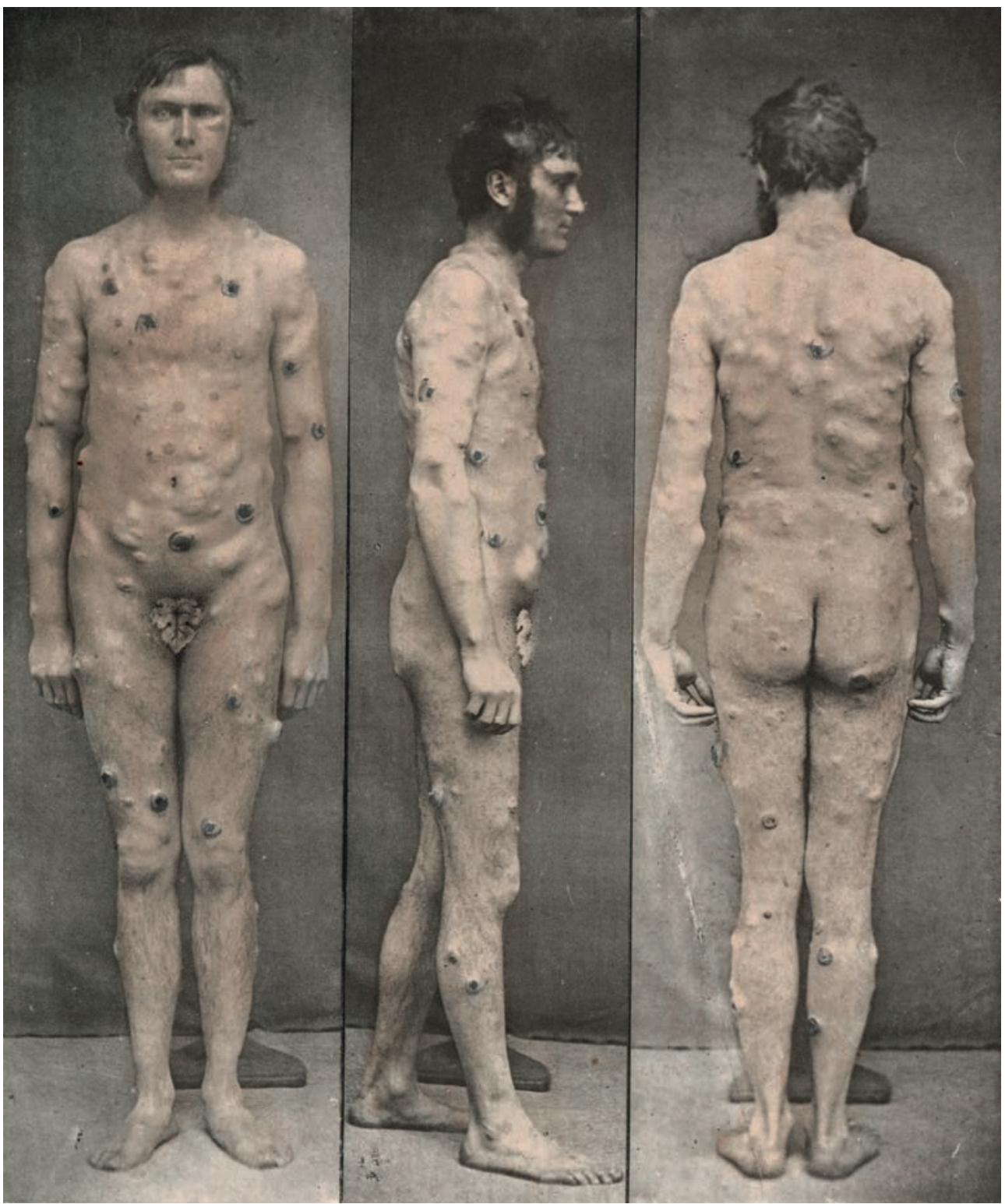

Figure 5.11 'Sarcoma.' In Fox, G. H. (1882). Library Universiteit van Amsterdam.

The appropriation of photography in dermatology in particular played a role in the emerging convention of concealing the patient's identity in case of nudeness or a socially stigmatising affection. Medical historian Andreas Maehle has argued that apart from stigmatisation, the social status (class) of the patient was also important in the choice to cover the face of the patient. ${ }^{123}$ Maehle suggested that the intentional anonymisation 
of patients in clinical photography started with patients of a higher social class suffering from socially stigmatising diseases. ${ }^{124}$ It was no coincidence that these photographs were published in a dermatological section of a medical atlas. The appropriation of photographical depiction in dermatology therefore charged the emergence of specific conventions in medicine in general. Widespread dissemination of photographs called for the construction of boundaries between the public and the private, the decent and the indecent, between the medical and the non-medical. The development of pictorial conventions served as standards to demarcate medical photography from popular forms of photography.

\section{Standardising diseased skin: demarcating professional depiction}

In the last decade of the nineteenth century new standards developed for medical photography. Hospitals were equipped with their own photographic studios and specialists in medical photography. With the professionalisation of dermatology, medical photography as such also became institutionalised. Pictorial standards were introduced to demarcate between medical professional and public photography. Any possible blurring between popular photography and professional photography needed to be prevented. Whereas anonymisation emerged in the American and English contexts of professional photographers in particular, other standards came up in the clinical context of hospitals in France. The emergence of pictorial standards was crucial in the appropriation of photography by dermatologists (and other medical specialists), as it demarcated between professional and popular photography.

Many pictorial standards in dermatological photography were developed in a clinical institutional setting. In France clinical photography started in the hospitals of Paris. The dermatological work of Hardy and de Montméja started off clinical photography. The patients in this atlas were often depicted in head-on poses, a sign of bluntness and unsophisticated portraiture of inferior classes. ${ }^{125}$ Later, this form of frontality in photography was also seen in prison records of inmates as a code of social inferiority. ${ }^{126}$ In the work of Hardy and De Montméja frontality is a remarkable returning visual code for the photography of skin diseases. During the 1860s and 1870s Paris hospitals set up their own photographic services. De Montméja started the service at the SaintLouis in 1869, while Charcot and Richer established the Service photographique de la Salpêtrière in 1878 for the preparation of the Nouvelle iconographie de la Salpêtrière. ${ }^{127}$ Dr Charcot then famously used photography to read the bodily signs of the mentally insane. This photographic service was directly linked to the clinic for diseases of the nervous system at the Salpêtrière. In around 1888 the photographic service at the Salpêtrière had developed into a fully equipped studio with dark and light laboratories,

124 Ibid., p. 580.

125 See Tagg, J. (1988), p. 36.

126 Ibid., p. 37. See also: Sekula, A. (1989).

127 Kemp, M. (1997), p. 139-140. Journal: Nouvelle iconographie de la Salpêtrière (1888). Paris: Lecrosnier et Babè. On the photography at the Salpêtrière hospital see: Didi-Huberman, G. (2003). 


\section{Chapter 5}

platforms, beds, screens and backdrops in black, dark grey and light grey and headrests to keep the patient's head still. ${ }^{128}$ Specific photographic conventions for the depiction of patients rapidly took shape in these in-house photographic units of the Paris hospitals.

The continuing specialisation and professionalisation of medical photography in France culminated in the publication of one of the earliest handbooks on medical photography in 1893. La photographie médicale was written by photographer and scientist Albert Londe (1858-1917). ${ }^{129}$ Londe was the successor to Charcot at the photographic service of the Salpêtrière and the author of a host of books about photography in science and medicine. In La photographie médicale Londe aimed to provide a description for physicians who wanted to set up a photographic service themselves. ${ }^{130} \mathrm{He}$ therefore discussed all the technical and practical details involved in the applications of photography in medicine and science. He tackled subjects such as photography of living and deceased patients, the posing of the patient, the background of the clinical photograph and medical-legal photography. In a chapter on the photography of living patients Londe provided detailed instructions on the depiction of the head, the hands and the feet and also on the photography of skin diseases. In the section on skin diseases Londe referred to the work of Hardy and de Montméja and explained how to approach the photography of diseased skin:

On sait que les maladies de la peau sont très nombreuses; leur étude par la photographie peut donc présenter un intérêt spécial. Les difficultés que l'on rencontra fréquemment tiendront à l'échelle des épreuves qui devra être souvent assez grande et aux colorations antiphotogéniques des tissus superficiels altérés. Il faudra opérer, en général, d'assez près et diaphragmer quelque peu pour avoir netteté parfaite. ${ }^{31}$

However, in his book Londe mostly discussed the standard ways of photographing the mentally ill. His descriptions of the surroundings of the patient later became standards in many medical domains, including the photography of skin diseases. Londe explained how the backdrop to the photograph should consist of grey or blue curtains, a background that we would now call 'neutral'. ${ }^{132}$ With these colours the reflections on the nude patient would have the most "harmonious" effects for the photographs, without producing strong differences between light areas and shadows. ${ }^{133}$ Although the patient would have to have as 'natural' a pose as possible, Londe's descriptions abounded in directions for standardising the medical photograph. He included, for example, a table of light intensity on the different days and months of the year in Paris, so as to be

128 Didi-Huberman, G. (2003), p. 45.

129 Londe, A. (1893). La photographie médicale: application aux sciences médicales etphysiologiques. Paris: Guathier-Villars. On photographic practice of Londe see: Didi-Huberman, G., J. (2003); and Graver, N. M. (1975). Photographie Médicale - Albert Londe's 1893 book, first in the field. Journal of the Biological Photographic Association, 43, 95102 .

130 Londe, A. (1893), p. x.

131 Londe, A. (1893), p. 83

132 Ibid., p. 15.

133 Idem. 
able to adapt the lightening strategies. ${ }^{134}$ Similarly, Londe only briefly touched upon the issue of colouring of photographs of skin diseases. Only under the strict supervision of a expert physician would colouring be allowed. ${ }^{135}$

The issue of anonymisation does not seem to play a role in Londe's environment. At the service of his predecessor, Charcot, photography concentrated on depicting mentally ill patients. Londe therefore spends most of his time explaining how to correctly photograph the poses and movements in hysteria, catalepsy and other correlating diseases. Londe also referred to the installation of special windows in the photographic atelier, so as to prevent "les vues du dehors". ${ }^{136}$ Standardising the practices of photography therefore also involved a physical disconnection from the outside world by internalising the practice into the hospital. ${ }^{137}$ With the description of the photography of skin diseases in Londe's handbook, the photographic visualisation of diseased skin had been standardised and taken up in a new field of medicine.

The appropriation of photography in dermatology was not a simple or straightforward process. Enthusiasm for photography gradually gave way to practical problems and implementation as well as to disagreement and discussion. Dermatologists found new ways of depicting patients with skin diseases in a constant interchange with existing pictorial conventions and popular developments in photography. New standards emerged in a dynamic between professional visual language of depicting skin diseases and popular photographic conventions. In an era of specialisation in medicine and unlimited duplication and circulation of images, the depiction of patients with skin diseases gained a new dimension. After a wander off the paths of medicine, the depiction of diseased skin was taken back by medicine again.

134 Londe, A. (1893), p. 47.

135 Ibid., p. 85.

136 bid., p. 11.

137 The emergence of common standards in dermatological photography also became clear in other national contexts. The dermatological photographs from the archive of the University Museum of the University of Utrecht in the Netherlands exemplify the changes that had taken place in the depiction of skin diseases with the appropriation of photography. These photographs are known under the name 'Narath-Laméris' and originate from the University Hospital in Utrecht. The photographs date from 1890-1940. With the arrival of surgeon A. Narath 1896, a photographical practice was set off. This practice was institutionally established in 1908 with a studio and a dark room as a special place inside the hospital. The attention for photography was probably brought in from Vienna, where Narath had his surgical training with professor Billroth. For examples see: Kooiker, P., Emmerik, P., Troost, F., \& Zoetendaal, W. van (1999). Utrechtse krop. Utrecht: Academisch Ziekenhuis Utrecht. In 1889, a Dutch dermatologist working at the medical faculty in Amsterdam had already published a work with clinical photographs of skin diseases: Haren Noman, D. J. v. (1889). Casuistique et diagnostic photographique des maladies de la peau. Haarlem: De Erven F. Bohn. The clinical photographs from the dermatological collection of the University Hospital in Utrecht display many of the standards as developed and set up at the end of the nineteenth century. The patients were photographed against a plain white background in back and white photography. The convention of anonymisation was also apparent in two cases. One photograph from 1934 shows a man who had tattoos over his entire body. He was wearing black glasses (black mask) to cover his eyes. The other case concerns a photograph from 1892 of a sergeant with syphilis. His eyes are whitened with a kind of white paint applied on the photograph itself. 
Chapter 5 


\section{6 \\ Conclusion}

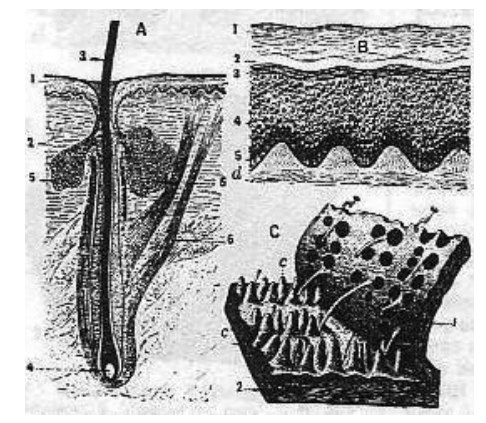

Figure 6.1 Peau. (1897). In C. Augés Nouveau

Larousse illustré. Dictionnaire universel encyclopédique.

This picture was worth looking at. It epitomises the changes in conception of skin that took place in nineteenth-century medicine. From an open permeable layer the skin was visually redefined into a protective boundary layer for the body. Skin became an attractive object - healthy or diseased - for physicians to investigate and depict in different ways, for diverse purposes, in ever-changing contexts. Whereas microscopical pictures of skin visually redefined the skin as a thick boundary layer in the first half of the nineteenth century, soap advertisements carried a moral plea for skin cleanliness that far excelled the idea of ads as mere commercial devices. Indeed, microscopical and other kinds of medical depictions of skin in the nineteenth century are much more than illustrations. Before reading this book the above picture could have been dismissed as an enjoyable, yet hardly significant by-product of a 1897 encyclopaedic definition of skin. However, in this book I have shown how a picture like this one was at the centre of a complex of ways of depiction, knowledge practices and technology.

The chapters of this book have examined the functions and uses of pictures of skin in nineteenth-century medicine. Not only the occasionally well-known beautiful or unpleasant pictures of skin (diseases) individually deserve attention. My discussions of pictures of skin have focused on the various roles pictures play within an ensemble of knowledge production and dissemination, technologies and pictorial contexts. In the works of physicians on classifications of skin diseases, in the microscopical context in Germany in the early decades of the nineteenth century, in the context of sanitary reforms in Britain and in the context of early medical photography, pictures of skin 


\section{Chapter 6}

gained different meanings and performed different roles. Depictions of skin introduced skin as an organ with its own pathologies, an object of medical enquiry and individual treatment, a protective layer with sweat glands, a surface of social control and shame and a surface of care and cleanliness. Yet depictions of skin also brought these meanings of skin into society by acting as visual articulations, persuasive devices, communicative vehicles and normative or contentious objects. New ways of knowing skin went hand in hand with new ways of depicting skin.

The historically contextualised pictures of skin are part of visual culture. Ways of depicting skin were developed in medical visual vocabularies and standardised in common pictures. As argued in chapters two and three, physicians developed standard ways of depicting diseased and healthy skin to discuss treatments and classifications of skin diseases and the anatomy of skin with colleagues. The cases of skin cleanliness and the photography of skin diseases in chapters four and five show how visual language is not merely about dissemination of knowledge but also about normative and controversial depiction. Travelling within medicine and beyond, pictures of the skin traverse the professional and specialist boundaries of medical and research practices. Whereas physicians deployed visual language of diseased skin and microscopical depiction primarily as 'internal' means, chapters four and five stressed the interconnectedness of medico-scientific conceptions of skin and popular culture. The case of the popular Pears' soap advertisements (chapter four) and the photographic depictions of skin diseases (chapter five) exemplify this entwinement of professional and specialist knowledge of the skin and popular culture.

This book therefore moves beyond the understanding of visual language as a strictly internally directed means of communication for specialists and professionals. The concept of visual language is especially useful as a tool for analysing the multiple functions of pictures in the field of medical science. In knowledge practices of science, visualisation might be about argument instead of illustration. ${ }^{1}$ In addition to the function of argumentation, depiction acquires multiple functions and uses in medicine, which are best analysed using the concept 'visual language'. As the illustration from the Larousse encyclopaedia at the beginning shows, visual language does not necessarily remain within the boundaries of scientific or medical disciplines. Clearly, the standard microscopical image of the skin as described in chapter three has become part of medical science as well as part of popular imagination. Visual language works across disciplinary boundaries, intended or unintended, desired or undesired. On the one hand the popularisation and education of the public about clean skin in chapter four demonstrates the connection between medical conceptions about skin and soap advertisements. The appropriation of photography in chapter five on the other hand exemplifies the undesired and unintended link between professional specialist photographs of skin diseases and popular conventions and discussions. In both cases visual language plays a part in linking or demarcating the professional and the public/popular.

1 Norton Wise, M. (2006), p. 81: "The import of visualization in science, therefore, is not illustration but argument." 


\section{Conclusion}

More specifically, the introduction of photography for the depiction of diseased skin urged medical professionals to reassess and revise their ways of depiction. The long-term perspective in this book points to the changes that occurred in the depiction of diseased skin with the introduction of photography. While the macromorphological and the clinical styles of depicting skin diseases were extended with photography, new aspects of popular photography also entered the stage. The reinstallation or reformulation of standards in medical (and dermatological) photography may be noted as the construction of boundaries of the visual language. Unwanted associations with popular connotations of photography were banned and the edges of the visual language were sharpened. In terms of 'boundary-work', this case presents the protection of the credibility of the visual language. ${ }^{2}$ Ways of depicting do not of and by themselves remain within the domain of specialists. The appropriation of a new technology such as photography may not only lead to new devices (camera) and products (photographs), but also to unforeseen struggles with the uses of that technology. Within medical practices of use the boundaries of the visual are constantly invaded, re-drawn, enforced and protected. The subject of demarcation brings the implicit relationship to the fore that medical depictions share with popular everyday images. Suddenly, the photographs of skin diseases are not merely instructive in the depiction of diseases, but also for their similarity to photographic portraits, candid photographs of celebrities and even nude photography.

Yet ways of depicting skin were also involved with a desired expansion of medical knowledge beyond the limits of the professionals towards a larger lay audience. In analysing the popularisation of medicine, the study of pictures as visual language may serve as a fresh entry into the subject. Both popularisation and educational activities often involve a kind of visual language. The propagation of skin cleanliness in Britain in the second half of the nineteenth century involved pictures as important vehicles for the creation of social awareness of clean skin. Soap advertisements reinforced the call for personal involvement and the use of soap to become clean of skin and mind. The intermediary status of pictures of skin, then, was explicitly addressed by stressing the ability of pictures of skin to traverse domains of specialists and lay audiences. At the same time pictures of skin not only brought medical knowledge of skin into the public domain, but also connected microscopy to standard pictures of skin, classifications of skin diseases to professional systems of depiction and photography of skin diseases to portrait photography and privacy issues. It was precisely the specific ability of pictures to figure in various medical or non-medical contexts that was stressed in all the cases discussed. The analyses of depicting skin has specified what Michael Lynch has described as the intermediary status of visualisation. ${ }^{3}$ Pictures of skin in nineteenth-century dermatology, microscopy, public hygiene and medical photography acted as junctions of knowledge generation and audiences, technological processes and knowledge dissemination, and

2 On boundary-work and credibility contests see: Gieryn, T. F. (1999). Cultural boundaries of science: credibility on the line. Chicago: University of Chicago Press.

3 Lynch, M. (1998), p. 223: "Visual images are intersubjective: they stand between persons, and between persons and things; they are both material and symbolic; they integrate things with projects; they incorporate verbal references into their frames and supply scenic contexts for interpreting them." 


\section{Chapter 6}

popular culture and professional domains.

My approach is fruitful and stimulating for the analysis of historical pictures of the body in several respects. Medical pictures of skin were more than illustrations. They even had more functions aside from their uses in arguments or as historical evidence in medicine $^{4}-$ they perform multiple roles. This is where the academic disciplines of history of medicine, history of science and visual studies find their common ground: visual cultures of knowledge. In his work Visual studies: a skeptical introduction, art historian James Elkins argued for a transition of the field of 'visual culture' into 'visual studies' as "the study of visual practices across all boundaries". 5 So far scholars in the field of visual culture have first and foremost been concerned with the history of "the modern tendency to picture or visualize existence". ${ }^{6}$ While the nineteenth century is recognised as a central period for discussions on changing visual culture ${ }^{7}$, medical and scientific images are underexplored as part of everyday life in visual culture studies. At the same time pleas in the history of science argue for the study of pictures to "recognize the heterogeneity of scientific representations, the different circumstances of their production, and the variety of cultural and social functions they serve". ${ }^{8}$ The cases of depiction of skin in this book have demonstrated the fruitful analysis of pictures combining insights from the history of medicine, the history of science and visual studies. Without considering the wider context of dermatological and microscopic pictures of skin, the fascinating dynamic tensions and interactions within medical visual culture and between medical visualisation and popular culture remain out of sight. Jennifer Tucker has argued in general for a meeting of the history of science and visual culture in the study of scientific representations by looking at pictorial landscapes in a broader sense. ${ }^{9}$ The analysis of depicting skin in nineteenth-century medicine puts flesh on such a plea and further specifies the visual history of the body in medicine. Visualisation of the body in nineteenth-century medicine revolved around classifications and demonstration of new knowledge, tensions between depiction of standard type and depiction of the individual case and prevailing social standards for bodily care and display.

Technology played an important role in changing and travelling ways of depicting skin. Technological artefacts, materials, techniques and skills influenced ways of depicting skin. Indeed, the ways of depicting diseased skin were heavily affected by the introduction and appropriation of photography by physicians in the second half of the nineteenth century. With photography as a new technique for the reproduction of

4 Burke, P. (2001). Eyewitnessing: the uses of images as historical evidence. London: Reaktion.

5 Elkins, J. (2003). Visual studies: a skeptical introduction. New York, N.Y.: Routledge, p. 7.

6 Mirzoeff, N. (1999), p. 5.

7 Schwartz, V. R., \& Przyblyski, J. (Eds.). (2004). The nineteenth-century visual culture reader. New York, NY: Routledge.

8 Tucker, J. (2006), p. 119.

$9 \quad$ Ibid., pp. 119-120: "scientific representations derive meaning not only from their location in the history of scientific theories and practices but also in competition and dynamic tension with forms of art and visual culture that are often outside the usual purview of the historian of science. Taking a wider view of the pictorial landscapes in which scientific representations derive their meaning and significance will yield new historical perspectives on scientific practices, visual culture, and the writing of history". 


\section{Conclusion}

diseased skin in patients, a new visual awareness of the patients as individuals entered the visual language. On a different scale the use of the microscope for the anatomical investigation of the skin in the first half of the nineteenth century also deeply affected the characteristics of the anatomical depiction of skin in medicine. The uses of the new technologies of visualisation and investigation therefore required changes in dealing with the visualisation and understanding of skin. In accordance with Anne Shelbey Blum's analysis of natural history and zoological illustration in nineteenth-century America, my study of depicting skin demonstrates how visual language interacts with changing practices, technologies and social developments. ${ }^{10}$ Whereas Blum's story mostly delves into the social history of illustration techniques and pictorial conventions, my argument points to the importance of technologies of investigation and dissemination in shaping visual language of skin in the nineteenth century within a broader visual culture. At first sight a strong parallel may be drawn between Blum's description of the introduction of photography in zoology and my analysis of the appropriation of photography for the depiction of skin diseases. In both cases the popular use of photography resulted in unforeseen changes in styles of illustration. In the case of zoology photomechanical reproduction "enforced a reduction to line and reinforced a growing tendency from within biology towards schematization". ${ }^{11}$ In the case of the appropriation of photography in medicine the depiction of the patient was readjusted and newly standardised. Photographs were praised for their lifelikeness in the reproduction of patients and skin diseases. Whereas Blum's authors applauded accuracy, physicians were looking for lifelikeness. Colours were essential in this respect, as they enhanced the lifelikeness of the depictions of patients. This important difference points to a divergence between the historical depiction of non-human objects of nature and living human subjects. Pictures of nature are no pictures of bodies.

What is so special about pictures of the skin? In what way is this analysis of visual language specific to the history of skin and depiction of the body? Whereas pictures of nature confront the spectator with the beauty of their surroundings, pictures of skin are able to confront the spectator with images of his or her own body and bodies that surround him/her. Recently, historians of science have paid attention to scientific images in a larger visual context. Anne Secord discussed the power of pictures in early nineteenth-century popular botany. ${ }^{12}$ She argued that pictures acted as a means of encouraging people to become botanists. Her analysis emphasises the role of pictures of plants in popular science as a means of recruitment. Other discussions of visualisations of nature include the work of Katherine Anderson on Victorian meteorology. She stressed the role of images of clouds in a visual context as both objects of scientific study and popular aesthetics. ${ }^{13}$ Yet contrary to pictures of plants and clouds, medical pictures

10 See Blum, A. S. (1993), p. 4 on note 6.

11 Blum, A. S. (1993), p. 265. See also chapter seven: The lens and the line: Photography and microscopy.

12 Secord, A. (2002). Botany on a plate. Pleasure and the power of pictures in promoting early nineteenth-century scientific knowledge. Isis, 93, 28-57.

13 Anderson, K. (2003). Looking at the sky: the visual context of Victorian meteorology. British Journal for the History of Science, 36(3), 301-332. 


\section{Chapter 6}

of skin as discussed in this book would not always be considered a source of pleasure or beauty. The viewer is not necessarily lured into a love of skin by these pictures. Instead, the pictures might provoke reactions of shock, rejection, awe, recognition or perhaps compassion. This is because we are looking at pictures of the body, of persons, not of plants, clouds or minerals. A reassessment of the roles of pictures of the body in medicine should therefore include greater awareness of knowledge of the body as a social entity in a popular visual context.

Pictures of skin confront us, as spectators, with our own bodies. The historical study of visual culture of skin raises interesting issues that are less evident in a study of the depiction of nature. The quest for clean skin in sanitary endeavours and soap advertisements pointed to the emergence of both individual responsibility and social control for proper care of the human body. In pursuit of skin cleanliness, then, a morale of cleanliness was attached to the skin demanding internalised self-control of the body. Judgments of outside appearance became related to a clean healthy skin. Pictures of skin consequently affected perceptions of people's own bodies. What's more, the urge to protect the privacy of the patient in medical photography at the end of the nineteenth century reaffirms the mirroring of contemporary societal worries and attention to the visual exposure of bodies. Depicting skin was about the presentation and dissemination of knowledge, but even more so about society's preoccupations with human bodies at that particular time.

The study of depicting skin, as opposed to other parts of the human body, is particularly apt for raising issues such as privacy and morality. ${ }^{14}$ The issues connected with the skin as raised in this book are of a social and cultural nature. Modern meanings of the skin are strongly linked to the emergence of the individual as an enclosed human being, a central issue in microscopical depictions of skin. ${ }^{15}$ What is striking about the depiction of skin is the almost tangible tension between the depiction of the individual, the type and the abstracted fragment. This tension is related to the integrity or unity of skin covering almost the entire body. Claudia Benthien has argued that the modern notion of the skin as a closure and boundary surface was part of a changing picture of the body to a closed, demarcated individual body in the early nineteenth century. ${ }^{16}$ All the same, this book shows that the history of skin is about both individual bodies and the visual confrontations with bodies of others. The historical episodes of depicting skin in nineteenth-century medicine show that conceptions of the skin as covering of the individual body at the same time need an understanding of skin as a mirror of

14 Studies of the depiction of the eye in nineteenth century medicine, would involve significant questions about the psychology of vision, colour, perception and modernity. See for example: Crary, J. (1990). Techniques of the observer: On vision and modernity in the nineteenth century. Cambridge, Mass. and London: MIT Books; Utz, P. (1990). Das Auge und das Ohr im Text: literarische Sinneswahrnehmung in der Goethezeit. München: Fink; Jay, M. (1993). Downcast eyes: The denigration of vision in twentieth-century French thought. Berkeley, Calif., etc.: University of California Press; Brennan, T., \& Jay, M. (Eds.). (1996). Vision in context: Historical and contemporary perspectives on sight. New York: Routledge.

15 See Benthien's discussion of Norbert Elias' picture of the individual human being as Homo clausus. Benthien, C. (2002), p. 29.

16 Benthien, C. (2002), p. 62. 


\section{Conclusion}

society. Ultimately, what is so special about pictures of skin is that they mirror our own (contemporary) particularities of dealing with bodies.

The depiction of skin proved to yield more than lines on a piece of paper. Views on our own ways of understanding and depicting the human body have gained an historical perspective. A look at our skin became a journey inside history. After all, who would not agree with Francis Pears when he wrote in 1859: "The importance of the subject of the human skin, on which not only beauty but health depends, can scarcely be exaggerated. By its structure and condition the whole of the internal economy is influenced. Neither the eye, the hair, the figure, nor the manner, exert an influence in love, compared to that inspired by the fairness and perfection of the skin". ${ }^{17}$ 
Chapter 6 


\section{Bibliography}

Alfaric, A. (1917). J. L. Alibert: fondateur de la dermatologie en France: sa vie, son oeuvre, 1768-1837. Paris: J.-B. Baillière.

Alibert, J. L. M. (1814). Description des maladies de la peau observées à l'Hôpital Saint-Louis. Paris: Barrois, Snr.

Alibert, J. L. M. (1817). Nosologie naturelle, ou les maladies du corps humain distribuées par familles. Paris: Caille \& Ravier.

Alibert, J. L. M. (1825). Description des maladies de la peau, observées à l'Hôpital Saint-Louis, et exposition des meilleures méthodes suivies pour leur traitement (2 ed.). Bruxelles: Auguste Wahlen, discours préliminaire.

Alibert, J. L. M. (1832). Monographie des dermatoses, ou, précis théorique et pratique des maladies de la peau. Paris: Chez le Docteur Daynac.

Alibert, J. L. M. (1833). Clinique de l'hôpital Saint-Louis ou traité complet des maladies de la peau. Paris: Cormon et Blanc.

Amirault, C. (1993). Posing the subject of early medical photography. Discourse, 16(2), 51-76.

Anderson, K. (2003). Looking at the sky: the visual context of Victorian meteorology. British Journal for the History of Science, 36(3), 301-332.

Anzieu, D. (1989). The skin ego: a psychoanalytic approach to the self (C. Turner, Trans.). New Haven, Conn: Yale University Press.

Augé, C. (Ed.). (1897). Nonveau Larousse illustré. Dictionnaire universel encyclopédique. Paris: Librairie Larousse.

Baigrie, B. S. (Ed.). (1996). Picturing knowledge: historical and philosophical problems concerning the use of art in science. Toronto: The University of Toronto Press.

Bakhtin, M. (1984). Rabelais and his world (H. Iswolsky, Trans.). Bloomington: Indiana University Press.

Bateman, T. (1812). A biographical memoir of the late Dr. Willan. Edinburgh Medical and Surgical Journal, $8,502-512$.

Bateman, T. (1813). A practical synopsis of cutaneous diseases according to the arrangement of Dr. Willan, exhibiting a concise view of the diagnostic symptoms and the method of treatment. London: Longman.

Bateman, T. (1814). A practical synopsis of cutaneous diseases according to the arrangement of Dr. Willan, exhibiting a concise view of the diagnostic symptoms and the method of treatment (Third ed.). London: Longman, Hurst, Rees, Orme, and Brown.

Bateman, T. (1817). Delineations of cutaneous diseases: exhibiting the characteristic appearances of the principal genera and species comprised in the classification of the late Dr. Willan; and completing the series of engravings begun by that author. London: Longman, Hurst, Rees, Orme, and Brown.

Bateman, T., \& Thomson, A. T. (1829). A practical synopsis of cutaneous diseases according to the arrangement of Dr. Willan, exhibiting a concise view of the diagnostic symptoms and the method of treatment (7th ed.). London: Printed for Longman, Rees, Orme, Brown \& Green.

Becker, P., \& Clark, W. (Eds.). (2001) Little tools of knowledge. An Arbor: The University of Michigan Press.

Béclard, P. A. (1823). Élémens d'anatomie générale ou description de tous les genres d'organes qui composent le corps humain. Paris: Béchet.

Beeson, B. B. (1930). Pierre François Rayer 1793-1867. Archives of Dermatology and Syphilology, 22, 863-867.

Behrend, F. J. (1839). Ikonographische Darstellung der nichtsyphilitischen Hautkrankheiten. Leipzig: F.A. Brockhaus. 


\section{Bibliography}

Benthien, C., \& Wulf, C. (2001). Körperteile: eine kulturelle Anatomie (Orig.-Ausg. ed.). Reinbek bei Hamburg: Rowohlt Taschenbuch Verlag.

Benthien, C. (2002). Skin: on the cultural border between self and the world. (T. Dunlap, Trans.). New York: Columbia University Press.

Beswick, T. S. L. (1957). Robert Willan: The solution of a ninety-year-old mystery. Journal of the History of Medicine and allied Sciences, 12, 349-367.

Blum, A. S. (1993). Picturing nature: American nineteenth-century zoological illustration. Princeton N.J.: Princeton U.P.

Bohde, D. (2003). Abgeschunden, gegerbt und beschriftet - die menschliche Haut als mahnendes Schaustück in der niederländischen Anatomietradition. In U. Zeuch (Ed.), Verborgen im Buch, verborgen im Körper: Haut, zwischen 1500 und 1800. (pp. 131-137). Wiesbaden: Harrassowitz.

Bohde, D. (2003). Skin and the search for the interior: The representation of flaying in the art and anatomy of the cinquecento. In F. Egmond \& R. Zwijnenberg (Eds.), Bodily extremities: preoccupations with the human body in early modern European culture. (pp. 10-47). F Aldershot etc.: Ashgate.

Boissier de Sauvages, F. (1763). Nosologia methodica sistens morborum classes, genera et species, juxta Sydenhami mentem et botanicorum ordinem. Amsterdam: Frères De Tournes.

Bolton, R. (Ed.). (1989). The contest of meaning: critical histories of photography. Cambridge, MA: MIT Press.

Booth, C. C. (1968). Robert Willan MD FRS FSA. The British Journal of Dermatology, 80, 459-467.

Bourneville, D. M., \& Regnard, P. (Eds.). (1875). Iconographie photographique de la Salpêtrière. Paris: A. Delahaye.

Bracegirdle, B. (1993). The microscopic tradition. In W. F. Bynum \& R. Porter (Eds.), Companion encyclopedia of the history of medicine (pp. 102-119). London: Routledge.

Brennan, T., \& Jay, M. (Eds.). (1996). Vision in context: Historical and contemporary perspectives on sight. New York: Routledge.

Breschet, G. (1823). Über zwei neugeborne und hirnlose wasserköpfige Kinder. Deutsches Archiv fïr die Physiologie, 8, 151-156.

Breschet, G., \& Raspail, F. (1828). Ricerche microscopiche sulla struttura dei nervi. Annali universali di medicina Serie 1, 46, Fascicolo 136.

Breschet, G. (1833). Études anatomiques et physiologiques sur l'organe de l'ouie et sur l'audition, dans l'homme et les animaux vertébrés. Présentées à Académie royale des sciences le 27 Aout 1832. Paris: Madame Veuve Thuau.

Breschet, G., \& de Vauzème, A. R. (1834). Nouvelles recherches sur la structure de la peau. Annales des Sciences naturelles. Tome second. Septembre, Octobre et Décembre.

Breschet, G., \& de Vauzème, A. R. (1835). Nouvelles recherches sur la structure de la peau. Paris: J.-B. Ballière.

Brockhaus. (1898). Brockhaus' Konversations-Lexicon (Vierzehnte vollständig neubearbeitete Auflage). Revisierte Jubiläums-Ausgabe. Leipzig: Brockhaus.

Broman, T. H. (1996). The transformation of German academic medicine, 1750-1820. Cambridge: Cambridge University Press.

Bueck-Rich, U. (1970). Ernst Heinrich Weber (1795-1878) und der Anfang einer Physiologie der Hautsinne. Juris: Zürich.

Burke, P. (2001). Eyewitnessing: the uses of images as historical evidence. London: Reaktion.

Burns, S. B. (1979a). Early medical photography in America (1839-1883). New York State Journal of Medicine, 79(5), 788-795. 


\section{Bibliography}

Burns, S. B. (1979b). Early medical photography in America (1839-1883). II. Physicians and early photography. New York State Journal of Medicine, 79(6), 943-947.

Burns, S. B. (1979c). Early medical photography in America (1839-1883). III. The daguerrean era. New York State Journal of Medicine, 79(8), 1256-1268.

Burns, S. B. (1980a). Early medical photography in America (1839-1883). V. Beginnings of psychiatric photography. New York State Journal of Medicine, 80(2), 270-282.

Burns, S. B. (1980b). Early medical photography in America (1839-1883). VI. Civil War medical photography. New York State Journal of Medicine, 80(9), 1444-1469.

Burns, S. B. (1981). Early medical photography in America (1839-1883). VII. American medical publications with photographs. New York State Journal of Medicine, 81(8), 1226-1264.

Bushman, R. L., \& Bushman, C. L. (1988). The early history of cleanliness. The Journal of American History, 74(4), 1213-1238.

Bynum, W. F., \& Porter, R. (Eds.). (1993). Medicine and the five senses. Cambridge: Cambridge U.P.

Bynum, W. F., \& R. Porter (Eds.). (1993). Companion encyclopedia of the history of medicine. London: Routledge.

Bynum, W. F. (1993). Nosology. In W. F. Bynum \& R. Porter (Eds.), Companion encyclopedia of the history of medicine (Vol. 1, pp. 335-356). London: Routledge.

Bynum, W. F. (1994). Science and the practice of medicine in the nineteenth century. Cambridge: Cambridge University Press.

Cahan, D. (Ed.). (2003). From natural philosophy to the sciences. Chicago/London: The University of Chicago Press.

Calmann, L., \& Bruyn, H. de (1839). Beknopt handboek der huidziekten, volgens het Willan-Batemansche stelsel. Amsterdam: s.n.

Cambrosio, A., Jacobi, D., \& Keating, D. (1993). Ehrlich's "Beautiful Pictures" and the controversial beginnings of immunological imagery. Isis 84, 662-699.

Cazenave, P. L. A., \& Schedel, H. É. (1828). Abrégé pratique des maladies de la peau: d'après les auteurs les plus estimés, et surtout d'après des documents puisés dans les leçons cliniques de M. le docteur Biett. Paris: Béchet jeune.

Cazenave, P. L. A., \& Schedel, H. É. (1833). Abrégé pratique des maladies de la peau, d’après les auteurs les plus estimés et surtout d'après les documents puisés dans les leçons cliniques de M. le docteur Biett (2e ed.). Paris.

Chadarevian, S. de (1993). Instruments, illustrations, skills, and laboratories in nineteenth-century German botany. In R. G. Mazzolini (Ed.), Non-verbal communication in science prior to 1900 (pp. 529-562). Firenze: Olschki.

Chadwick, E. (1877). Skin cleanliness; head to foot washing; public measures proposed for its promotion. Journal of the Society of Arts, August 17, 883-886.

Clinical photography. (1895). The British Medical Journal, I(June 22), 1402.

Coleman, W. (1982). Death is a social disease: public health and political economy in early industrial France. Madison, Wis.; London: University of Wisconsin Press.

Coleman, W., \& Holmes, F. L. (Eds.). (1988). The investigative enterprise: experimental physiology in nineteenthcentury medicine. Berkeley Calif.: University of California Press.

Coleman, W. (1988). Prussian pedagogy: Purkyne at Breslau, 1823-1839. In W. Coleman \& F. L. Holmes (Eds.) The investigative enterprise: experimental physiology in nineteenth-century medicine (pp. 15-64). Berkeley Calif.: University of California Press. 


\section{Bibliography}

Connor, S. (2004). The book of skin. Ithaca, New York: Cornell University Press.

Cooter, R., \& Pumfrey, S. (1994). Separate spheres and public places: reflections on the history of science popularization and science in popular culture. History of Science, 32, 237-267.

Corbin, A., Courtine, J.-J., \& Vigarello, G. (Eds.). (2005). Histoire du corps. 2. De la Révolution à la Grand Guerre (Vol. 2). Paris: Seuil.

Crary, J. (1990). Techniques of the observer: On vision and modernity in the nineteenth century. Cambridge, Mass. and London: MIT Books.

Crary, J., \& Kwinter, S. (Eds.). (1992). Incorporations. New York: Zone.

Crissey, J. T. (1951). Early dermatologic illustration. A.M.A. Archives of Dermatology and Syphilology, 64, $417-$ 424.

Crissey, J. T., \& Parish, L. C. (1981). The dermatology and syphilology of the nineteenth century. New York, N.Y: Praeger division of CBS Educational and Professional Publishing.

Crissey, J. T., Parish, L. C., \& Holubar, K. (2002). Historical atlas of dermatology and dermatologists. Boca Raton etc.: Parthenon Publishing Group.

Cunningham, A. (2002). The pen and the sword: recovering the disciplinary identity of physiology and anatomy before 1800. I: Old physiology - the pen. Studies in History and Philosophy of Biological and Biomedical Sciences, 33, 631-665.

Dahm, S. (1981). Frühe Krankenbildnisse: Alibert, Esquirol, Baumgärtner. Köln: Forschungsstelle des Instituts für Geschichte der Medizin der Universität zu Köln.

Damon, H. F. (1870). Photographs of skin diseases. Boston: James Campbell.

Daniel, C. F., \& Boissier de Sauvages, F. (1790-1797). Nosologia methodica sistens aegritudines morbos passiones ordine artificiali ac naturali. Castigavit emendavit auxit icones ... adiecet C.F. Daniel. Lipsiae, E.B. Schwickerti.

Daston, L., \& Galison, P. (1992). The image of objectivity. Representations(40), 81-128.

Daston, L. (2001). Scientific objectivity with and without words. In P. Becker \& W. Clark (Eds.), Little tools of knowledge (pp. 259-284). An Arbor: The University of Michigan Press.

Daston, L. (Ed.). (2004). Things that talk. Object lessons from art and science. New York: Zone Books.

Dempsey, M., \& Pears A. and F. Limited. (1978). Bubbles: early advertising art from A. \& F. Pears Ltd. London: Fontana.

Dennis, M. A. (1989). Graphic understanding: Instruments and interpretation in Robert Hooke’s Micrographia. Science in Context, 3(2), 309-364.

Dermer, R. A. (Ed.). (1999). Medicine and photography [Special issue]. History of Photography, 23(3).

Dickens's dictionary of London: an unconventional handbook. (1885). London: MacMillan.

Didi-Huberman, G. (2003). Invention of hysteria: Charcot and the photographic iconography of the Salpêtrière (A. Hartz, Trans.). Cambridge, Mass: The MIT Press.

Dijck, J. van (2005). The transparent body: a cultural analysis of medical imaging. Seattle, WA: University of Washington Press.

Donné, A., \& Foucault, L. (1845). Cours de microscopie complémentaire des études médicales: anatomie microscopique et physiologie des fluides de l'économie. Paris: JB Baillière.

Douglas, M. (1991). Purity and danger: an analysis of concepts of pollution and taboo (2nd ed.). London: Routledge. (Original work published 1966)

Duden, B. (1991). The woman beneath the skin: a doctor's patients in eighteenth-century Germany (T. Dunlap, Trans.). Cambridge, Mass: Harvard University Press. 


\section{Bibliography}

Duffy, J. (1990). The sanitarians: a history of American public health. Urbana: University of Illinois Press.

Dürbeck, G., Schickore, J. \& Wiesenfeldt, G. (Eds.). (2001). Wahrnehmung der Natur-Natur der Wahrnehmung: Studien zur Geschichte visueller Kultur um 1800. Dresden, Verlag der Kunst.

Edgerton, S. Y. (1985). The Renaissance development of the scientific illustration. In J. W. Shirley \& F. D. Hoeniger (Eds.), Science and the arts in the Renaissance (pp. 168-197). Washington, London, Toronto: Associated University Presses.

Editorial: The craze for photography in medical illustration. (1894). The New York Medical Journal, 59 (June 9), 721-722.

Egmond, F., \& Zwijnenberg, R. (Eds.). (2003). Bodily extremities: preoccupations with the human body in early modern European culture. Aldershot: Ashgate.

Ehring, F. (1989). Hautkrankheiten: 5 Jahrhunderte wissenschaftlicher Illustration. Stuttgart: Fischer Verlag.

Eichhorn, H. (1826). Ueber die Aussonderungen durch die Haut und über die Wege, durch welche sie geschehen. Archiv für Anatomie und Physiologie, 405-486.

Elkins, J. (2003). Visual studies: a skeptical introduction. New York, N.Y. etc.: Routledge.

Everett, M. A. (1984). Jean Louis Alibert. The father of French dermatology. International Journal of Dermatology, 23(5), 351-356.

Ewing, W. A. (1994). The body: photoworks of the human form. London: Thames and Hudson.

Feher, M., Naddaff, R., \& Tazi, N. (Eds.). (1989). Fragments for a history of the human body. New York: Urzone.

Fend, M. (2005). Bodily and pictorial surfaces: skin in French art and medicine, 1790-1860. Art History, 28(3), 311-339.

Findlay, G. H. (1949). The achievement of Robert Willan. British Journal of Dermatology, 61(8-9), 281-286.

Finer, S. E. (1952). The life and times of Sir Edwin Chadwick. London: Methuen.

Finnerud, C. W. (1952). Ferdinand von Hebra and the Vienna School of Dermatology. A.M.A. archives of dermatology and syphilology, 66, 223-232.

Foucault, M. (1963). La naissance de la clinique: une archéologie du régard médical. Paris: Gallimard.

Fournier, M. (1985). De microscopische anatomie in Bidloo's Anatomia Humani Corporis (1685). Tijdschrift voor de geschiedenis der geneeskunde, natuurwetenschappen, wiskunde en techniek, 8(4), 187-208.

Fournier, M. (1996). The fabric of life: microscopy in the seventeenth century. Baltimore: The Johns Hopkins University Press.

Fox, D. M., \& Terry, J. (1978). Photography and the self image of American physicians, 1880-1920. Bulletin of the History of Medicine, 52, 435-457.

Fox, D. M., \& Lawrence, C. (1988). Photographing medicine: images and power in Britain and America since 1840. New York: Greenwood Press.

Fox, G. H. (1880). Photographic illustrations of skin diseases. New York: E. B. Treat.

Fox, G. H. (1881). Photographic illustration of cutaneous syphilis. New York: E. B. Treat.

Fox, G. H. (1882). Iconographie photographique des maladies de la peau (J.-B. Holman, Trans.). Paris: Librairie J.-B. Ballière et Fils.

Fox, G. H. (1905). Photographic atlas of the diseases of the skin: a series of ninety-six plates, comprising nearly two hundred illustrations, with descriptive text, and a treatise on cutaneous therapeutics (Physician's ed.). Philadelphia; London: J.B. Lippincott.

Fox, G. H. (1926). Reminiscences. New York: Medical Life Press.

Fox Talbot, W. H. (1980). Some account of the art of photogenic drawing, or, the process by which natural objects may be made to delineate themselves without the aid of the artist's pencil. In B. Newhall (Ed.), 


\section{Bibliography}

Photography: essays \& images. Illustrated readings in the history of photography. (pp. 23-30). New York: Museum of Modern Art. (Original paper published 1839).

Freund, G. (2004). Precursors of the photographic portrait. In V. R. Schwartz \& J. Przyblyski (Eds.), The nineteenth-century visual culture reader (pp. 79-82). New York, NY: Routledge.

Frey, M. (1997). Der reinliche Bürger: Entstehung und Verbreitung bürgerlicher Tugenden in Deutschland, 17601860. Göttingen: Vandenhoeck und Ruprecht.

Geimer, P. (Ed.). (2002). Ordnungen der Sichtbarkeit. Frankfurt am Main: Suhrkamp.

Gernsheim, A. (1961). Medical photography in the nineteenth century, Part I. Medical and Biological Illustration, 11, 85-92.

Ghesquier, D. (1999). A Gallic affair: The case of the missing itch-mite in French medicine in the early nineteenth century. Medical History, 43, 26-54.

Gibbs, F. W. (1939). The history of the manufacture of soap. Annals of Science, 4, 169-190.

Gieryn, T. F. (1999). Cultural boundaries of science: credibility on the line. Chicago: University of Chicago Press.

Gijswijt-Hofstra, M., \& Porter, R. (Eds.). (1998). Constructing Paris medicine. Amsterdam: Rodopi.

Gillispie, C. C. (Ed.). (1975). Dictionary of scientific biography. New York: Charles Scribner's Sons.

Gilman, S. L. (Ed.). (1976). The face of madness: Hugh W. Diamond and the origin of psychiatric photography. New York: Brunner/Mazel.

Gilman, S. L. (1982). Seeing the insane: a cultural history of madness and art in the western world, showing how the portrayal of stereotypes has both reflected and shaped the perception and treatment of the mentally disturbed. New York: Wiley in association with Brunner-Mazel.

Gilman, S. L. (1995). Health and illness: images of difference. London: Reaktion Books.

Gold, S. (1998). Erasmus Wilson - philanthropic polymath: an enigmatic personality. Journal of Medical Biography, 6(2), 97-104.

Gombrich, E. H. (1960). Art and illusion: a study in the psychology of pictorial representation (1st ed.). London: Phaidon Press.

Gomes, B. A. (1823). Ensaio dermosographico, ou succinta e systematica descripção das doenças cutaneas conforme os principios e observaçôes dos doutores Willan e Bateman, com indicação dos respectivos remedios aconselhados por estos celebres authores e alguns outros. (2nd ed.). Lisboa: Typ. de Academia Real des Sciencias.

Goubert, J.-P. (1989). The conquest of water: the advent of health in the industrial age (A. Wear, Trans.). Cambridge: Polity.

Graver, N. M. (1975). Photographie Médicale - Albert Londe’s 1893 book, first in the field. Journal of the Biological Photographic Association, 43, 95-102.

Green, J. (1838). A practical compendium of the diseases of the skin. Philadelphia: A. Waldie.

Grew, N. (1684). The description and use of the pores in the skin of the hands and feet, by the learned and ingenious Nehemiah Grew, M.D. Fellow of the College of Physicians and of the Royal Society. Philosophical Transactions, 14, 566-567.

Gurlt, E. F. (1835). Vergleichende Untersuchungen über die Haut des Menschen und der Haus-Säugethiere, besonders in Beziehung auf die Absonderungs-Organe des Haut-Talges und des Schweisses. Archiv fur Anatomie, Physiologie und wissenschaftliche Medicin, 399-418.

Hacking, I. (1983). Representing and intervening. Cambridge: Cambridge University Press.

Hadley, R. M. (1959). The life and works of Sir William James Erasmus Wilson (1809-84). Medical History, 3, 215-247. 


\section{Bibliography}

Hagner, M. (Ed.). (2001). Ansichten der Wissenschaftsgeschichte. Frankfurt: Fischer.

Hagner, M. (2003). Scientific medicine. In D. Cahan (Ed.) From natural philosophy to the sciences (pp. 49-87). Chicago/London: The University of Chicago Press.

Haldin-Davis, H. (1931). The foundations of British dermatology. Annals of Medical History, 3, 368-386.

Hall, S. (1997). Representation: cultural representations and signifying practices. London: Sage.

Hamilton, P., \& Hargreaves, R. (2001). The beautiful and the damned: the creation of identity in nineteenth century photography. Aldershot: Lund Humphries London in association with the National Portrait Gallery.

Hamlin, C. (1998). Public health and social justice in the age of Chadwick: Britain, 1800-1854. Cambridge: Cambridge University Press.

Hanke, C., \& Nössler, R. (Eds.). (2003). Haut. Tübingen: konkursbuch Verlag Claudia Gehrke.

Hannaway, C. (1981). From private hygiene to public health: A transformation in Western medicine in the eighteenth and nineteenth centuries. In T. Ogawa (Ed.), Public health: Proceedings of the 5th international symposium on the comparative history of medicine - East and West (pp. 109-128). Tokyo: Saikon.

Hannaway, C. \& La Berge, A. (Eds.). (1998). Constructing Paris medicine. Amsterdam, Atlanta G.A.: Rodopi.

Hansell, P. (1959). Victorian clinical photography. Medical and Biological Illustration, 9, 70-77.

Hardy, A., \& de Montméja, A. (1868). Clinique photographique de l'hôpital Saint-Louis. Paris: Librairie Chamerot et Lauwereyns.

Hardy, A., \& de Montméja, A. (1878). Clinique photographique des maladies de la peau. Paris: Lauwereyns.

Haren Noman, D. J. v. (1889). Casuistique et diagnostic photographique des maladies de la peau. Haarlem: De Erven F. Bohn.

Harting, P. (1848). Het mikroskoop, deszelfs gebruik, geschiedenis en tegenwoordige toestand. Tweede deel. Utrecht, Van Paddenburg \& Comp.

Harting, P. (1859). Das Mikroskop: Theorie, Gebrauch, Geschichte und gegenwärtiger Zustand desselben. (D. F. W. Theile, Trans.). Braunschweig: F. Vieweg und Sohn.

Hebra, F., Elfinger, A., \& Heitzmann, C. (1856-1876). Atlas der Hautkrankheiten / Text von Ferdinand Hebra; Bilder von Anton Elfinger und Carl Heitzmann; herausgegeben durch die Kaiserliche Akademie der Wissenschaften. Wien: Druck der Kaiserlich-Königlichen Hof- und Staatsdruckerei in Commission bei C. Gerold's Sohn.

Henle, F. G. J. (1841). Allgemeine Anatomie-Lehre von den Mischungs- und Formbestandtheilen des menschlichen Körpers. Leipzig: Leopold Voß.

Hill, C., \& Helmers, M. (Eds.). (2004). Defining visual rhetorics. Mahwah, NJ: Lawrence Erlbaum.

Hoffmann, C. (2001). Haut und Zirkel. Ein Entstehungsherd: Ernst Heinrich Webers Untersuchungen "Ueber den Tastsinn”. In M. Hagner (Ed.) Ansichten der Wissenschaftsgeschichte (pp. 191-223). Frankfurt: Fischer.

Houwaart, E. S. (1991). De hygiënisten: Artsen, staat en volksgezondheid in Nederland 1840-1890. Groningen: Historische Uitgeverij.

Huard, P., \& Imbault-Huart, M.-J. (1975). Gilbert Breschet ou le savant polyglotte (Clermont-Ferrand, 7 juillet 1784 - Paris 10 mai 1845). Gazette Médicale Tome 82(23), 2839-2840.

Hufeland, C. W. (1797). Die Kunst das menschliche Leben zu verlängern. Jena: Akademische Buchhandlung.

Hufeland, C. W. (1859). The art of prolonging life (E. Wilson, Trans. 2 ed.). London: Churchill.

Hufeland, C. W. (1971). Die Kunst das mensliche Leben zu verlängern (Faksimile-Ausgabe des Originals von 1797 ed.). Hamburg: Lichters. 


\section{Bibliography}

Hunt, J. A. (1999). A short history of soap. The Pharmaceutical Journal, 263(7076), 985-989.

Indecent photographs. (1868). The Photographic Journal (June 16), 80.

Jacquin, J. v. (1829). Bemerkungen über Mikroskope und ihren Gebrauch für Naturforscher. Zeitschrift für Physik und Mathematik, 5, 129-160.

Jacyna, L. S. (1998). Pious pathology: J.L. Alibert's iconography of disease. In M. Gijswijt-Hofstra \& R. Porter

(Eds.), Constructing Paris medicine (pp. 185-219). Amsterdam: Rodopi.

Jay, M. (1993). Downcast eyes: The denigration of vision in twentieth-century French thought. Berkeley, Calif., etc.: University of California Press.

Jenks, C. (Ed.). (1995). Visual culture. New York: Routledge.

Jones, C. A., \& Galison, P. (Eds.). (1998). Picturing science, producing art. London/New York: Routledge

Joost , T., \& van Everdingen, J. J. E. (Eds.). (1996). Omtrent de huid. Cultuurhistorische verkenningen. Amsterdam/Overveen: Boom/Belvédère.

Keiller, W. (1894). Letters to the editor: The craze for photography in medical illustration. The New York Medical Journal, 59(Jun 23), 788-789.

Kemp, M. (1993). The mark of truth: looking and learning in some anatomical illustrations from the

Renaissance and eighteenth century. In W. F. Bynum \& R. Porter (Eds.), Medicine and the five senses (pp. 85-121). Cambridge: Cambridge U.P.

Kemp, M. (1996). Temples of the body and temples of the cosmos: Vision and visualization in the Vesalian and

Copernican revolutions. In B. S. Baigrie (Ed.), Picturing knowledge: historical and philosophical problems concerning the use of art in science (pp. 41-85). Toronto: University of Toronto Press

Kemp, M. (1997). "A perfect and faithful record": mind and body in medical photography before 1900. In A. Thomas (Ed.), Beauty of another order: photography in science (pp. 120-149). New Haven: Yale University Press.

Kemp, M., Wallace, M., \& Londen, H. G. (2000). Spectacular bodies: the art and science of the human body from Leonardo to now. London: Hayward Gallery Berkeley, CA: University of California Press.

Kimpel, M. (1981). Über den Atlas der Hautkrankheiten (1856-1876) von Ferdinand von Hebra (1816-1880). Köln: Institut für Geschichte der Medizin der Universität.

Knight, D. M. (1985). Scientific theory and visual language. Acta Universitatis Upsaliensis, Series 22, 106124.

Knight, D. M. (1993). Pictures, diagrams and symbols: Visual language in nineteenth-century chemistry. In R. G. Mazzolini (Ed.), Non-verbal communication in science prior to 1900 (pp. 321-344). Firenze: Olschki.

Knight, D. M. (1996). Illustrating chemistry. In B. S. Baigrie (Ed.), Picturing knowledge: Historical and philosophical problems concerning the use of art in science. (pp. 135-163). Toronto etc.: The University of Toronto Press.

Knoeff, R. (2003). Over 'Het kunstige, toch verderfelyke gestel'. Een cultuurhistorische interpretatie van Bidloos anatomische atlas. Gewina, 26, 189-202.

Kölliker, A. von (1850). Mikroskopische Anatomie oder Gewebelehre des Menschen 2.Band 1.Hälfte: Specielle Gewebelhre von der Haut, den Muskeln, Knochen und Nerven. Leipzig: Wilhelm Engelmann Verlag.

Kölliker, A. von (1852). Handbuch der Gewebelehre des Menschen. Leipzig: W. Engelmann.

Kooiker, P., Emmerik, P., Troost, F., \& Zoetendaal, W. van (1999). Utrechtse krop. Utrecht: Academisch Ziekenhuis Utrecht.

Krause, C. F. T. (1844). Haut. In R. Wagner (Ed.), Handwörterbuch der Physiologie: mit Rücksicht auf physiologische Pathologie. Zweiter Band (pp. 108-186). Braunschweig: Vieweg. 


\section{Bibliography}

Krauss, R. H. (1978). Photographs as early scientific book illustrations. History of Photography, 2(4), 291314.

Kruta, V. (1975). Purkyne (Purkinje), Jan Evangelista. In C. C. Gillisepie (Ed.) Dictionary of scientific biography (p. 214). New York: Charles Scribner's Sons.

Laarse, R. van der, Labrie, A., \& Melching, W. (1998). De hang naar zuiverheid: de cultuur van het moderne Europa. Amsterdam: Het Spinhuis.

La Berge, A. \& Feingold, M. (Eds.). (1994). French medical culture in the nineteenth century. AmsterdamAtlanta G A: Rodopi.

La Berge, A. (1994). Medical microscopy in Paris, 1830-1855. In A. La Berge \& M. Feingold (Eds.), French medical culture in the nineteenth century (pp. 296-326). Amsterdam-Atlanta G A: Rodopi.

La Berge, A. (1998). Dichotomy or integration? Medical microscopy and the Paris clinical tradition. In C. Hannaway \& A. La Berge (Eds.), Constructing Paris medicine (pp. 275-312). Amsterdam, Atlanta G.A.: Rodopi.

La Berge, A. (1999). The history of science and the history of microscopy. Perspectives on Science, 7(1), 111 142.

Labisch, A. (1992). Homo hygienicus: Gesundheit und Medizin in der Neuzeit. Frankfurt/Main; New York: Campus Verlag.

Lachmund, J. (1997). Der abgehorchte Körper. Zur historischen Soziologie der medizinischen Untersuchung. Wiesbaden: Westdeutscher Verlag.

Lane, J. E. (1926). Robert Willan. Archives of Dermatology and Syphilology, 13(6), 737-760.

Lane, J. E. (1933). Joseph Jacob Plenck 1738?-1807. Archives of Dermatology and Syphilology, 28, 193-214.

Latour, B. (1990). Drawing things together. In M. Lynch \& S. Woolgar (Eds.), Representation in scientific practice (pp. 19-68). Cambridge/London: The MIT Press.

Latour, B. (1998). How to be iconophilic in art, science, and religion. In C. A. Jones \& P. Galison (Eds.), Picturing science, producing art (pp. 418-440). London/New York: Routledge.

Leeuwenhoek, A. van (1693). An extract of a letter from Mr. Anthony Van Leeuwenhoek, to the R. S. containing his observations on the seeds of cotton, palm, or date-stones, cloves, nutmegs, goose-berries, currans, tulips, cassia, lime-tree: On the skin of the hand, and pores, of sweat, the crystalline humour, optic nerves, gall, and scales of fish: and the figures of several salt particles, etc. Philosophical Transactions, 17, 949-960; p. 954-955.

Levell, N. J. (2000). Thomas Bateman MD FLS 1778-1821. British Journal of Dermatology, 143, 9-15.

Liebig, J. von (1844). Familiar letters on chemistry, and its relation to commerce, physiology, and agriculture (J. Gardner, Trans. 2nd corr. ed.). London: Taylor and Walton.

Londe, A. (1893). La photographie médicale: application aux sciences médicales et physiologiques. Paris: GuathierVillars.

Lorry, A.-C. (1777). Tractatus de morbis cutaneis. Parisiis: apud P. Guillelmum Cavelier.

Lynch, M. (1998). The production of scientific images: vision and re-vision in the history, philosophy, and sociology of science. Communication and Cognition, 31(2-3), 213-228.

Lynch, M., \& Woolgar, S. (Eds.). (1990). Representation in scientific practice. Cambridge, Mass: The MIT Press.

MacCormac, H. (1933). At the public dispensary with Willan and Bateman. The British Journal of Dermatology and Syphilis, 45, 385-895.

Maehle, A. H. (1986). Wie die Photographie zu ein Methode der Medizin wurde. Fortschritte der Medizin, 104(15), 63-65. 


\section{Bibliography}

Maehle, A. H. (1993). The search for objective communication: Medical photography in the nineteenth century. In R. G. Mazzolini (Ed.), Non-verbal communication in science prior to 1900 (pp. 563-586). Firenze: Leo S. Olschki.

Malpighi, M. (1975). Opera Omnia: figuris elegantissimus in aes incisis illustrata. Hildesheim etc.: Olms. Reprint of 1686.

Mazzolini, R. G. (Ed.). (1993). Non-verbal communication in science prior to 1900. Firenze: Olschki.

McClintock, A. (1998). Soft-soaping empire. Commodity racism and imperial advertising. In N. Mirzoeff (Ed.), The visual culture reader (pp. 304-316). London: Routledge.

Meckel, J. F., Breschet, G. et al. (1825). Manuel d'anatomie générale, descriptive et pathologique. Traduit de l'allemand, et augmenté par A.-J.-L. Jourdan et G. Breschet. Paris: J.B. Baillière.

Meckel, J. F., Breschet, G. et al. (1826). Manuale di anatomia generale, descrittiva e patologica. Tradotto del tedesco in francese, ed aumentato da A. G.L. Jourdan e G. Breschet. Versione italiana di P. Giusto. Naples: R. Manzi.

Meckel, J. F., Breschet, G. et al. (1838). Manual of descriptive and pathological anatomy. Translated from the German into French, with additions and notes, by A.J.L. Jourdan, and G. Breschet. Translated from the French, with notes, by A. S. Doane, and others. London: G. Henderson.

Medicus. (1894). Letters to the editor: Indecency in photography. The New York Medical Journal, 59(June 9), 724-725.

Mensel, R. E. (1991). «Kodakers laying in the wait»: Amateur photography and the right of privacy in New York. American Quarterly, 43(1), 24-45.

Mercurialis, H. (1601). De morbis cutaneis et omnibus corporis humani excrementis tractatus locupletissimi. Venetiis.

Meyer, E., \& Montméja, A. de (1871). Traité des opérations qui se pratiquent sur l'oeil. Paris: Lauwereyns.

Milton, J. L. (1879). The hygiene of the skin. London: Chatto and Windus.

Mirzoeff, N. (Ed.). (1998). The visual culture reader. London: Routledge.

Mirzoeff, N. (1999). An introduction to visual culture. London: Routledge.

Mohl, H. von (1846). Mikrographie oder Anleitung zur Kenntniss und zum Gebrauche des Mikroskops. Tübingen: L.F. Fues.

Montméja, A. de, \& Rengade, J. (Eds.). (1869). Revue photographique des hôpitaux de Paris. Paris: Adrien Delahaye, Libraire-Éditeur.

Nelson, R. S., \& Shiff, R. (Eds.). (2003). Critical terms for art history (2nd ed.) Chicago University of Chicago Press.

Nelson, R. S. (2003). Appropriation. In R. S. Nelson \& R. Shiff (Eds.), Critical terms for art history (2nd ed., pp. 160-173). Chicago University of Chicago Press.

Neumann, I. (1869). Lehrbuch der Hautkrankheiten. Wien: Wilhelm Braumüller.

Neuse, W. H. G., Neumann, N. J., Lehmann, P., Jansen, T., \& Plewig, G. (1996). The history of photography in dermatology: Milestones from the roots to the 20th Century. Archives of Dermatology, 132(12), $1492-$ 1498.

Newhall, B. (Ed.). (1980). Photography: essays \& images. Illustrated readings in the history of photography. New York: Museum of Modern Art.

Norton Wise, M. (2006). Focus: science and visual culture. Making visible. Isis, 97, 75-82.

Obituary - Sir Erasmus Wilson, F.R.C.S. (1884). The Lancet, August 16, 302-303.

O’Connor, E. (1999). Camera Medica. Towards a morbid history of photography. History of Photography, 23(3), 232-244. 


\section{Bibliography}

Ogawa, T. (Ed.). (1981). Public health: Proceedings of the 5th international symposium on the comparative history of medicine - East and West. Tokyo: Saikon.

Ollerenshaw, R. (1968). Medical illustration. The impact of photography on its history. Journal of the Biological Photographic Association, XXXVI, 3-13.

Ormsby, O. S. (1949). History of dermatology, 1847 to 1947. Archives of Dermatology and Syphilology, 59, 374-395.

Oudshoorn, N., \& Pinch, T. (Eds.). (2003). How users matter: the co-construction of users and technology. Cambridge, Mass: MIT Press.

Outram, D. (1989). The body and the French Revolution: sex, class and political culture. London: Yale University Press.

Pang, A. S.-K. (1997). Visual representation and post-constructivist history of science. Historical Studies in the Physical and Biological Sciences, 28(1), 139-172.

Past presidents of the College. 4. Sir Erasmus Wilson. (1952). Annals of the Royal Society of Surgeons of England, 10, 66-69.

Pazzini, K.-J. (2001). Haut: Berührungssehnsucht und Juckreiz. In C. Benthien \& C. Wulf (Eds.), Körperteile: eine kulturelle Anatomie (pp. 153-173). Reinbek bei Hamburg: Rowohlt Taschenbuch Verlag.

Pears, F. (1859). The skin, baths, bathing, and soap. London: The author, 91, Great Russell Street, Bloomsburry, (W.C.).

Pears'shilling cyclopaedia (1898). London: A. \& F. Pears.

Petherbridge, D., \& Jordanova, L. (1997). The quick and the dead: artist and anatomy. S.l.: The South Bank Center.

Pfeifer, K. (2000). Medizin der Goethezeit: Christoph Wilhelm Hufeland und die Heilkunst des 18. Jahrhunderts. Köln, Weimar, Wien: Böhlau.

Pickstone, J. V. (2000). Ways of knowing: a new history of science, technology and medicine. Chicago: The University of Chicago Press.

Piffard, H. G. (1888). Cutaneous photography made easy. Journal of Cutaneous and Genito-Urinary Diseases, $V I(2), 41-43$.

Pilloud, S., \& Louis-Courvoisier, M. (2003). The intimate experience of the body in the eighteenth century: between interiority and exteriority. Medical History, 47(4), 451-472.

Plenck, J. J. (1776). Doctrina de morbis cutaneis: Viennae.

Plenck, J. J. (1980). Leerstuk wegens de huidziekten: waar in deze gebreken onder hunne orden, geslagten en soorten gebragt worden (R. Arends, Trans.). Dordrecht: Nicolaas de Rot en Johannis Crevel Boekverkopers. Original published in 1776.

Porter, D. (1993). Public health. In W. F. Bynum \& R. Porter (Eds.), Companion encyclopedia of the history of medicine (Vol. 2, pp. 1231-1261). London: Routledge.

Porter, R. (2001). Bodies politic: disease, death and doctors in Britain, 1650-1900. London: Reaktion Books.

Prentice, R. (2005). The anatomy of a surgical simulation: The mutual articulation of bodies in and through the machine. Social Studies of Science, 35(6), 837-866.

Purkyne, J. E. (1823). Commentatio de Examine Physiologico Organi Visus et Systematis Cutanei. Vratislaviae: Typis Universitatis.

Purkyne, J. E. (1844). Mikroskop. In R. Wagner (Ed.), Handwörterbuch der Physiologie: mit Rücksicht auf physiologische Pathologie. Zweiter Band (pp. 411-441).Braunschweig: Vieweg. 


\section{Bibliography}

Purkyne, J. E., Kruta, V., Ebert, J., Zlábek, K. (1979). Abhandlung über die physiologische Untersuchung des Sehorgans und des Hautsystems / von Johann Evangelista Purkyně; ïbers. von Joachim Ebert und Karel Žlábek; eingeleitet und erläutert von Vladislav Kruta. Halle/Saale: Deutsche Akademie der Naturforscher.

Pusey, W. A. (1979). The history of dermatology. New York: AMS Press.

Rayer, P. F. O. (1826). Traité théorique et pratique des maladies de la peau, fondé sur de nouvelles recherches d'anatomie et de physiologie pathologiques. Paris: J.-B. Baillière.

Rayer, P. F. O. (1835). Traité théorique et pratique des maladies de la peau, avec un atlas in quarto (2me ed., entièrement ref.). Paris: J.B. Baillière.

Reed, B. (1889). Why physicians should cultivate photography. The Medical Record, November 9, 514-515.

Régnier, C. (1995). La photographie médicale (1839-1881). La revue du praticien, 45(7), 808-812.

Rheinberger, H.-J. (1994). Essay Review: Representation(s). Studies in History and Philosophy of Science, 25(4), 647-654.

Richards, T. (1990). The commodity culture of Victorian England: advertising and spectacle, 1851-1914. Stanford, CA: Stanford University Press.

Rosen, G. (1993). A history of public health (Expanded ed.). Baltimore and London: The Johns Hopkins University Press. (Original work published in 1958)

Rosenblum, N. (1997). A world history of photography (3rd ed.). New York: Abbeville.

Rudwick, M. J. S. (1976). The emergence of a visual language for geological science 1760-1840. History of science, $14,149-195$.

Ruestow, E. G. (1996). The microscope in the Dutch Republic: the shaping of discovery. Cambridge: Cambridge U.P.

Sarasin, P. (2001). Reizbare Maschinen: eine Geschichte des Körpers 1765-1914. Frankfurt am Main: Suhrkamp.

Schaffer, S. (2004). A science whose business is bursting: Soap bubbles as commodities in classical physics. In L. Daston (Ed.), Things that talk. Object lessons from art and science (pp. 147-194). New York: Zone Books.

Schickore, J. (2001a). Eröffnung der Augen: Auge und Sehen in der mikroskopischen Anatomie. In G. Dürbeck, J. Schickore \& G. Wiesenfeldt (Eds.), Wahrnehmung der Natur-Natur der Wahrnehmung: Studien zur Geschichte visueller Kultur um 1800 (pp. 165-177). Dresden, Verlag der Kunst.

Schickore, J. (2001b). Ever-present impediments: Exploring instruments and methods of microscopy. Perspectives on Science 9 (2), 127-146.

Schickore, J. (2002). Fixierung mikroskopischer Beobachtungen: Zeichnung, Dauerpräparat, Mikrofotografie. In P. Geimer (Ed.), Ordnungen der Sichtbarkeit (pp. 285-310). Frankfurt am Main: Suhrkamp.

Schickore, J. (2003). The ,philosophical grasp of the appearances' and experimental microscopy: Johannes Müller's microscopic research, 1824-1832. Studies in History and Philosophy of Biological and Biomedical Sciences 34, 569-592.

Schoeman, F. D. (Ed.). (1984). Philosophical dimensions of privacy: An anthology. Cambridge: Cambridge University Press.

Schwartz, V. R., \& Przyblyski, J. (Eds.). (2004). The nineteenth-century visual culture reader. New York, NY: Routledge.

Secord, A. (2002). Botany on a plate. Pleasure and the power of pictures in promoting early nineteenthcentury scientific knowledge. Isis, 93, 28-57.

Sekula, A. (1989). The body and the archive. In R. Bolton (Ed.), The contest of meaning: critical histories of photography (pp. 343-388). Cambridge, MA [etc.]: MIT Press. 


\section{Bibliography}

Shirley, J. W., \& Hoeniger, F. D. (Eds.). (1988). Science and the arts in the Renaissance. Washington, London, Toronto: Associated University Presses.

Simon, G. (1848). Die Hautkrankheiten durch anatomische Untersuchungen erläutert. Berlin: G. Reimer.

Sivulka, J. (2001). Stronger than dirt: a cultural history of advertising personal hygiene in America, 1875 to 1940. Amherst, NY: Humanity Books.

Slater, D. (1995). Photography and modern vision: The spectacle of 'natural magic'. In C. Jenks (Ed.), Visual culture (pp. 218-237). New York: Routledge.

Southworth, A. S. (1871). The early history of photography in the United States. The British Journal of Photography, 18, 530-532.

Squire, A. B. (1865). Photographs (coloured from life) of the diseases of the skin. London: J. Churchill and Sons.

Squire, A. J. B. (1868). A manual of the diseases of the skin. London: John Churchill.

Squire, A. B. (1878). Atlas of the diseases of the skin. London: J. \& A. Churchill, New Burlington Street.

Stafford, B. M. (1991). Body criticism: imaging the unseen in Enlightenment art and medicine. Cambridge, MA: The MIT Press.

Staughton, R. C. D., \& Smith, M. (2000). Choosing a dermatological hero for the Millennium. Clinical and Experimental Dermatology, 25(1), 82-95.

Sutton, R. L. (1986). Sixteenth century physician and his methods: Mercurialis on diseases of the skin. The first book on the subject (1572). Kansas City, Mo.: The Lowell Press.

Tagg, J. (1988). The burden of representation. Houndmills: Macmillan Press.

Taureck, R. (1980). Die Bedeutung der Photographie für die medizinische Abbildung im 19. Jahrh. Köln: Universität zu Köln.

The photographing of patients. (1895). The Lancet (July 13), 110.

Théodoridès, J. (1995). Pierre François Olive Rayer (1793-1867). Journal of Medical Biography, 3(4), 192196.

Thomas, A. (Ed.). (1997). Beauty of another order: photography in science. New Haven, London: Yale University Press in association with the National Gallery of Canada, Ottawa.

Thomson, A. T. (1829). Atlas of delineations of cutaneous eruptions; illustrative of the descriptions in the Practical synopsis of cutaneous diseases of Thomas Bateman. London: Longman, Rees, Orme, Brown, and Green.

Thyresson, N. (1986). Dermatology through the centuries: an exhibition from the Waller Collection. Uppsala, Reprocentralen HSC.

Tibbets, P. (1990). Representation and the realist-constructivist controversy. In M. Lynch \& S. Woolgar (Eds.), Representation in scientific practice (pp. 69-84). Cambridge, Mass: The MIT Press.

Tilles, G. (1989). La naissance de la dermatologie (1776-1880). Paris: Roger Dacosta.

Tilles, G., \& Wallach, D. (1989). Histoire de la nosologie en dermatologie. Ann. Dermatol. Venereol., 116, 9-26.

Tilles, G., \& Wallach, D. (1999). Robert Willan and the French Willanists. British Journal of Dermatology, 140(6), 1122-1126.

Tilles, G., \& Wallach, D. (2002). Les doctrines en dermatologie. In D. Wallach \& G. Tilles (Eds.), La dermatologie en France (pp. 63-76). Toulouse: Éditions Privat.

Towler, J. (1864). The silver sunbeam. New York: Joseph H. Ladd.

Tucker, J. (2006). The historian, the picture, and the archive. Isis, 97, 111-120.

Turner, D. (1714). De morbis cutaneis. A treatise of diseases incident to the skin. London: R. Bonwicke.

Turner, G. L. E. (1974). Microscopic communication. Journal of Microscopy 100(1), 3-20. 


\section{Bibliography}

Utz, P. (1990). Das Auge und das Ohr im Text: literarische Sinneswahrnehmung in der Goethezeit. München: Fink.

Vigarello, G. (1988). Concepts of cleanliness: changing attitudes in France since the Middle Ages (J. Birrell, Trans.). Cambridge: Cambridge University Press.

Vogel, J. (1841). Anleitung zum Gebrauch des Mikroskopes zur zoochemischen Analyse und zur mikroskopischchemische Untersuchung überhaupt. Leipzig: Leopold Voss.

Voorde, K. van de, Regenmortel, N. van, \& Hee, R. van (2003). Robert Willan (1757-1812) en de systematiek van de dermatologie. Geschiedenis der Geneeskunde, 9(5), 260-269.

Wagner, R. (1839). Erläuterungstafeln zur Physiologie und Entwickelungsgeschichte. Leipzig: Leopold Voss.

Wagner, R. (Ed.). (1842-1853). Handwörterbuch der Physiologie: mit Rücksicht auf physiologische Pathologie. Braunschweig: Vieweg.

Wallach, D., \& Tilles, G. (1991). L'oeuvre dermatologique de Pierre Rayer. Histoire des Sciences Médicales, 25, 278-284.

Wallach, D., \& G. Tilles (Eds.). (2002). La dermatologie en France. Toulouse: Éditions Privat.

Warren, S. D., \& Brandeis, L. D. (1984). The right to privacy. [The implicit made explicit]. In F. D. Schoeman (Ed.), Philosophical dimensions of privacy: an anthology (pp. 75-103). Cambridge: Cambridge University Press. (Original published in 1890, Harvard Law Review, IV(5).)

Wear, A. (1993). The history of personal hygiene. In W. F. Bynum \& R. Porter (Eds.), Companion encyclopedia of the history of medicine (Vol. 2, pp. 1283-1308). London: Routledge.

Weber, E. H. (1827). Beobachtungen über die Oberhaut, die Hautbälge und ihre Vergrösserung in Krebsgeschwülsten und über die Haare des Menschen. Archiv für Anatomie und Physiologie, 198-225.

Weber, E. H. (1835). Ueber den Tastsinn. Archiv für Anatomie, Physiologie und wissenschaftliche Medicin, $152-$ 160.

Weber, E. H. (1846). Der Tastsinn und das Gemeingefühl. In R. Wagner (Ed.) Handwörterbuch der Physiologie: mit Rücksicht auf physiologische Pathologie. Dritter Band (pp. 481-588). Braunschweig: Vieweg.

Wendt, A. (1833). De epidermide humana. Vratislav.

Wendt, A. (1834). Ueber die menschliche Epidermis. Archiv für Anatomie, Physiologie und wissenschaftliche Medicin, 278-291.

White, J.C. (1877). 'Healthy Skin', Boston Med. Surg. J., 46: 200-201.

Willan, R. (1798). Description and treatment of cutaneous diseases. Order 1. Papulous eruptions on the skin, coloured plates. London.

Willan, R. (1808). On cutaneous diseases. Vol. I. London: J. Johnson.

Williams, M. T. (1991). Washing "the great unwashed": public baths in urban America, 1840-1920. Columbus: Ohio State University Press.

Wilson, C. (1995). The invisible world: early modern philosophers and the invention of the microscope. Princeton N.J.: Princeton U.P.

Wilson, E. (1838). Practical and surgical anatomy. London: Longman, Orme, Brown, Green, \& Longmans.

Wilson, E. (1840). The anatomist's vade mecum; a system of human anatomy. London: Churchill.

Wilson, E. (1845). A practical treatise on healthy skin; with rules for the medical and domestic treatment of cutaneous diseases. London: John Churchill.

Wilson, E. (1847). On diseases of the skin (2nd ed.). London: John Churchill.

Wilson, E. (1849). On the management of the skin as a means of promoting and preserving health (3rd ed.). London: Churchill. 


\section{Bibliography}

Wilson, E. (1853). Healthy skin: a popular treatise on the skin and hair, their preservation and management (4th ed.). London: John Churchill.

Wilson, E. (1863). On diseases of the skin (Fifth American from the fifth and revised London ed.). Philadelphia: Blanchard and Lea.

Wilson, E. (1866). Healthy skin: a popular treatise on the skin and hair, their preservation and management (7th ed.). London: J. Churchill.

Wilson, E. (1868). Toilet soaps. Journal of Cutaneous Medicine and Diseases of the Skin, 1, 446-448.

Wilson, P. K. (1992). William Cowper's anatomy of human skin. International Journal of Dermatology, 31, 361-363.

Wilson, P. K. (1999). Surgery, skin and syphilis: Daniel Turner's London (1667-1741). Amsterdam: Rodopi.

Wohl, A. S. (1983). Endangered lives: public health in Victorian Britain. London: Dent.

Wright, T. (1867). Some habits and customs of the working classes. London: Tinsley Brothers, Catherine Street, Strand.

Zeuch, U. (Ed.). (2003). Verborgen im Buch, verborgen im Körper: Haut, zwischen 1500 und 1800. Wiesbaden: Harrassowitz.

Zwijnenberg, R. (1999). The writings and drawings of Leonardo da Vinci: order and chaos in early modern thought. (C.A. van Eck, Trans.). Cambridge: Cambridge University Press. 
Bibliography 


\section{Samenvatting}

Dit proefschrift analyseert medische afbeeldingen van het grootste orgaan van ons lichaam: de huid. In de negentiende eeuw was de afbeelding van de huid onderhevig aan veelvuldige veranderingen. Dit proefschrift laat zien hoezeer afbeeldingen van belang zijn voor kennisontwikkeling rond de huid in de geneeskunde in de negentiende eeuw. Tussen 1800 en 1900 ontstond een beeld van de huid als een functioneel orgaan met haar eigen specifieke ziekten, functies, microscopische architectuur, hygiëne-rituelen en normatieve waarden. Vier casussen over afbeelding van de huid als visuele cultuur van de geneeskunde belichten ieder een andere kant van wat ik als de 'visuele taal' van de huid benoem. Het gaat daarbij om de opkomst van dermatologische afbeeldingen in het begin van de negentiende eeuw, de microscopische afbeelding van de huid in de eerste helft van de negentiende eeuw, de verbeelding van de huid binnen de hygiëne-beweging in zeepadvertenties, en tot slot over de gevolgen van de opkomst van de fotografie voor de afbeelding van huidziekten. Steeds staat de vraag centraal welke rol afbeeldingen in de negentiende eeuw speelden in de medische kennisvorming rond de huid.

Dit proefschrift laat zien dat afbeeldingen veel meer zijn dan simpele illustraties bij tekst. Uitgaand van de complexe relatie tussen afbeeldingen en hun context, bespreek ik de verschillende rollen die afbeeldingen van de huid spelen in medische kennispraktijken. Door inzichten en methodes uit de medische geschiedenis, wetenschapsgeschiedenis en culturele studies te combineren wordt duidelijk dat manieren van afbeelden onlosmakelijk verbonden zijn met het maken, verspreiden en het gebruik van kennis. Terwijl afbeeldingen in de medische geschiedenis maar al te vaak worden afgedaan als bijzaak of juist als op zichzelf staande iconen worden beschouwd, tonen de vier casussen in dit proefschrift dat visuele representatie tot het hart van de omgang met medische kennis behoort. Opvattingen over de huid van negentiende-eeuwse artsen en onderzoekers zijn niet los te zien van afbeeldingen van de huid. Het onderzoek in dit proefschrift onderstreept dat aandacht voor afbeeldingen de medische geschiedenis enorm kan verrijken.

In het inleidende hoofdstuk zet ik uiteen hoe ik het concept 'visuele taal' gebruik voor de pragmatische historische analyse van de geschiedenis van de medische visualisering. De negentiende eeuw is bij uitstek een periode waarin nieuwe afbeeldings- en onderzoekstechnieken hun intrede doen, bijvoorbeeld de microscopie en de fotografie. In de Westerse medische wereld fungeerden afbeeldingen als een visuele taal, met een eigen 'vocabulaire' aan beelden, een eigen vermogen om kennis te genereren, een eigen normatieve dimensie, en het eigen vermogen om te communiceren tussen verschillende domeinen van wetenschap en populaire cultuur. Juist het geval van de verbeelding van de huid laat zien hoezeer afbeeldingen als taal functioneren tussen de domeinen van de geneeskunde en de populaire cultuur omdat daarbij, in de medische verbeelding, sociale normen over moraliteit een rol gingen spelen bij de verbeelding van kennis. De huid, als laag die bemiddelt tussen het lichaam en buitenwereld, fungeert bij uitstek ook als sociaal canvas. De afbeeldingen van huid en lichamen confronteert de kijker dan ook met zijn of haar eigen lichaam. De beelden belichamen niet alleen kennis, maar weerspiegelen 


\section{Samenvatting}

ook de sociaal historische context van die beelden. Dit maak ik duidelijk aan de hand van gedetailleerde medische geschiedenissen van vier soorten beelden, waarbij steeds een nieuw aspect van afbeeldingen als visuele taal naar voren komt. Tegelijkertijd ontvouwt zich aan de hand van de afbeeldingen een rijke geschiedenis van de huid.

De vroege afbeelding van huidziekten staat centraal in hoofdstuk twee. Illustraties uit Britse en Franse medische boeken over huidziekten laten zien hoezeer kennis en afbeelding samengaan. Hoewel in de geschiedenis van de dermatologie veel aandacht is besteed aan vroege indelingen van huidziekten enerzijds en afbeeldingen anderzijds, werden afbeeldingen en indelingen als kennisproductie niet eerder in relatie tot elkaar onderzocht. Ik laat zien dat er tussen 1790 en 1840 twee manieren ontstaan om de zieke huid af te beelden, elk gekoppeld aan een bepaalde indeling van huidziekten. De Britten Willan en Bateman gingen af op de lokale morfologie van de ziekte, zoals pukkels, blaren en vlekken. Zij beeldden de ziekten dan ook uit in anonieme fragmenten van huid. In Frankrijk ontwikkelde de arts Alibert een indeling van huidziekten die gebaseerd was op een klinisch totaalbeeld van de ziekte. In zijn boeken worden huidziekten visueel weergegeven in afbeeldingen van patiënten, ieder met hun eigen karakterisering als type persoon. In de loop van de eerste helft van de negentiende eeuw vervlochten de twee manieren van afbeelden zich, tegelijkertijd met het ontstaan van nieuwe indelingen van huidziekten. Maar juist de ontstaansgeschiedenis van afbeeldingen van huidziekten is zo interessant, omdat hierin de opkomst van een visueel vocabulaire van beelden duidelijk wordt. Artsen hadden nu een gezamenlijke beeldentaal om met huidziekten om te gaan. Uit dit hoofdstuk wordt duidelijk hoezeer kennis samengaat met afbeelding én omgekeerd.

Hoofdstuk drie gaat niet over de zieke huid, maar over de anatomie van de gezonde menselijke huid. Ik laat zien hoe de introductie van de microscopie als nieuwe onderzoekstechnologie sterk ingrijpt in het beeld van de huid. Ik toon aan dat in microscopisch onderzoek tussen 1820 en 1850 niet alleen een ander beeld van de huid ontstaat, maar dat de huid tegelijkertijd ook een andere betekenis krijgt. Van een poreuze laag die ziekten door kan laten, verandert de huid in een orgaan met haar eigen microscopische opmaak - voor ons in de $21^{\mathrm{e}}$ eeuw nog steeds herkenbaar. Aan de hand van het microscopisch onderzoek naar de huidporiën vertel ik hoe fysiologen en anatomen in Duitsland en Frankrijk een standaardbeeld van de microscopische anatomie van de huid ontwikkelden. Omdat microscopisch onderzoek zo nauw samengaat met afbeelden, werd de interne anatomie van de huid visueel gearticuleerd in de tekeningen. Zonder tekening geen nieuwe inzichten in de anatomie. Bovendien beschrijf ik hoe de microscopische afbeeldingen van de huid in publicaties een rol spelen als middel om het microscopisch onderzoek overtuigend te maken. De microscopische afbeeldingen waren schematische weergaven, samengesteld uit verschillende beelden en onderdelen, zoals de lagen van de huid, het zweetkliertje en het haar met de talgklier. De ontdekking van het zweetkliertje, zo toon ik aan, laat zien dat de huid verandert in betekenis van een open poreuze laag naar een bemiddelend orgaan tussen lichaam en buitenwereld. Door zowel medisch historici als cultureel historici is de geschiedenis van het lichaam in de negentiende eeuw nog niet eerder zo bezien.

In hoofdstuk vier traceer ik de rol van populaire medische beelden van de huid aan 


\section{Samenvatting}

de hand van zeepadvertenties. Binnen de hygiëne-beweging in Groot-Brittannië werd een schone huid verheven tot een moreel ideaal. Ik gebruik het werk van de Britse arts Wilson om te laten zien hoe het microscopische beeld van de huid werd ingezet in populair wetenschappelijke boeken om uit te dragen de huid gezond, schoon en rein te houden. Het controleren van de huid door haar te wassen met zeep ging veel verder dan het verwijderen van vuil; de drang naar een schone huid symboliseerde de controle die verkregen diende te worden over de 'gevaren' van de 'vuile' arbeidersklasse. Dit beeld wordt des te duidelijker in de analyse van zeepadvertenties van het merk 'Pears' soap'. Beelden van onverzorgde kinderen en gezonde mooie dames verspreidden de moraal van een schone huid tussen 1860 en 1900 tot op elke hoek van de straat. Dat juist de arts Wilson zelf figureert in de zeepadvertenties demonstreert dat de wetenschappelijke verbeelding van de huid direct aansluit bij de normatieve visualisering van de huid in het populaire domein.

In het vijfde hoofdstuk kom ik terug op de afbeelding van de zieke huid. De introductie van de fotografie in de dermatologie laat zien hoe artsen deze nieuwe afbeeldingstechnologie toe-eigenden en aanpasten aan hun eigen eisen en wensen. Foto's van huidziekten behoorden tot de eerste medische foto's die geproduceerd werden, maar werden tot nu toe echter zelden bekeken als onderdeel binnen een langer traject van afbeeldingen van de huid. De foto's van patiënten met huidziekten geproduceerd in medische atlassen tussen 1865 en 1900 geven niet alleen blijk van het enthousiasme voor fotografie als middel om objectieve, levensechte en accurate afbeeldingen te produceren. Uit mijn analyse komt naar voren dat ook populaire portretfotografie een belangrijke en controversiële rol speelde in de medische afbeelding van de huid. De medische foto's blijken oude en nieuwe illustratiemethoden te combineren, door oude tradities van afbeelden te koppelen aan innovaties, en te bemiddelen tussen populaire en specialistische visualiseringpraktijken. In tegenstelling tot de vaak veronderstelde breuk die de fotografie teweeg zou hebben gebracht in medische afbeeldingen, laat ik zien dat de introductie van de fotografie juist bewerkstelligde dat er een actief onderscheid geconstrueerd werd tussen populaire afbeelding en medische specialistische afbeelding. De ontwikkeling van standaarden voor de medische fotografie van huidziekten geven aan dat afbeeldingen als visuele taal steeds omstreden en bediscussieerd blijven.

In hoofdstuk zes wordt concluderend besproken welke geschiedenissen afbeeldingen van de huid vertellen. Door afbeeldingen niet te onderschatten als illustratieve 'plaatjes' wordt duidelijk dat zij belangrijke rollen vervullen in medische kennispraktijken. Ik bespreek op basis van de voorgaande casussen hoe afbeeldingen van de huid nieuwe kennis over de huid verspreiden, veranderen, opwekken, ter discussie stellen en in andere perspectieven plaatsen om zo een gevarieerd beeld te geven van de visuele cultuur van de geneeskunde in de negentiende eeuw. Afbeeldingen van de huid bemiddelen tussen de domeinen van de geneeskunde en populaire cultuur en belichten steeds andere kanten van de huid als medische kennisobject alsmede van de huid als sociaal gedefinieerd canvas. Zo geeft het boek niet alleen inzicht in de uiteenlopende betekenissen van negentiende-eeuwse medische afbeeldingen van de huid, maar ook in de geschiedenis van een belangrijk orgaan van onze lichaamscultuur. 


\section{Curriculum Vitae}

Mieneke te Hennepe was born on the sixth of November 1975 in Warnsveld, the Netherlands. After her secondary school education (VWO) between 1988 and 1994, she moved to Amsterdam where she studied Medical Biology and Science Dynamics at the Universiteit van Amsterdam. Before finishing her studies in 2001, she worked as a research assistant at the Department of Metamedica, Section History of Medicine at the VU University Medical Centre in Amsterdam in 2000. She started her PhD research at the Faculty of Arts and Social Sciences, Department of History of Maastricht University in 2001. The PhD project was part of a larger research program 'The Mediated Body', funded by the Netherlands Organisation for Scientific Research (NWO). For a short period, Mieneke was furthermore working as a part-time lecturer teaching courses in the bachelor program European Studies at the same faculty. As of September 2006, she is working as a curator in Museum Boerhaave, the National Museum of the History of Science and Medicine in Leiden. Besides her work in the museum, she also works parttime at the Faculty of Arts at Leiden University on the development of a Master course on art and science. 